Editora Poisson

\section{Educação no Século XXI - Volume 26 Especial - Inclusiva}

1a Edição

Belo Horizonte

Poisson

2019 
Editor Chefe: Dr. Darly Fernando Andrade

\section{Conselho Editorial}

Dr. Antônio Artur de Souza - Universidade Federal de Minas Gerais

Ms. Davilson Eduardo Andrade

Dra. Elizângela de Jesus Oliveira - Universidade Federal do Amazonas

Msc. Fabiane dos Santos Toledo

Dr. José Eduardo Ferreira Lopes - Universidade Federal de Uberlândia

Dr. Otaviano Francisco Neves - Pontifícia Universidade Católica de Minas Gerais

Dr. Luiz Cláudio de Lima - Universidade FUMEC

Dr. Nelson Ferreira Filho - Faculdades Kennedy

Ms. Valdiney Alves de Oliveira - Universidade Federal de Uberlândia

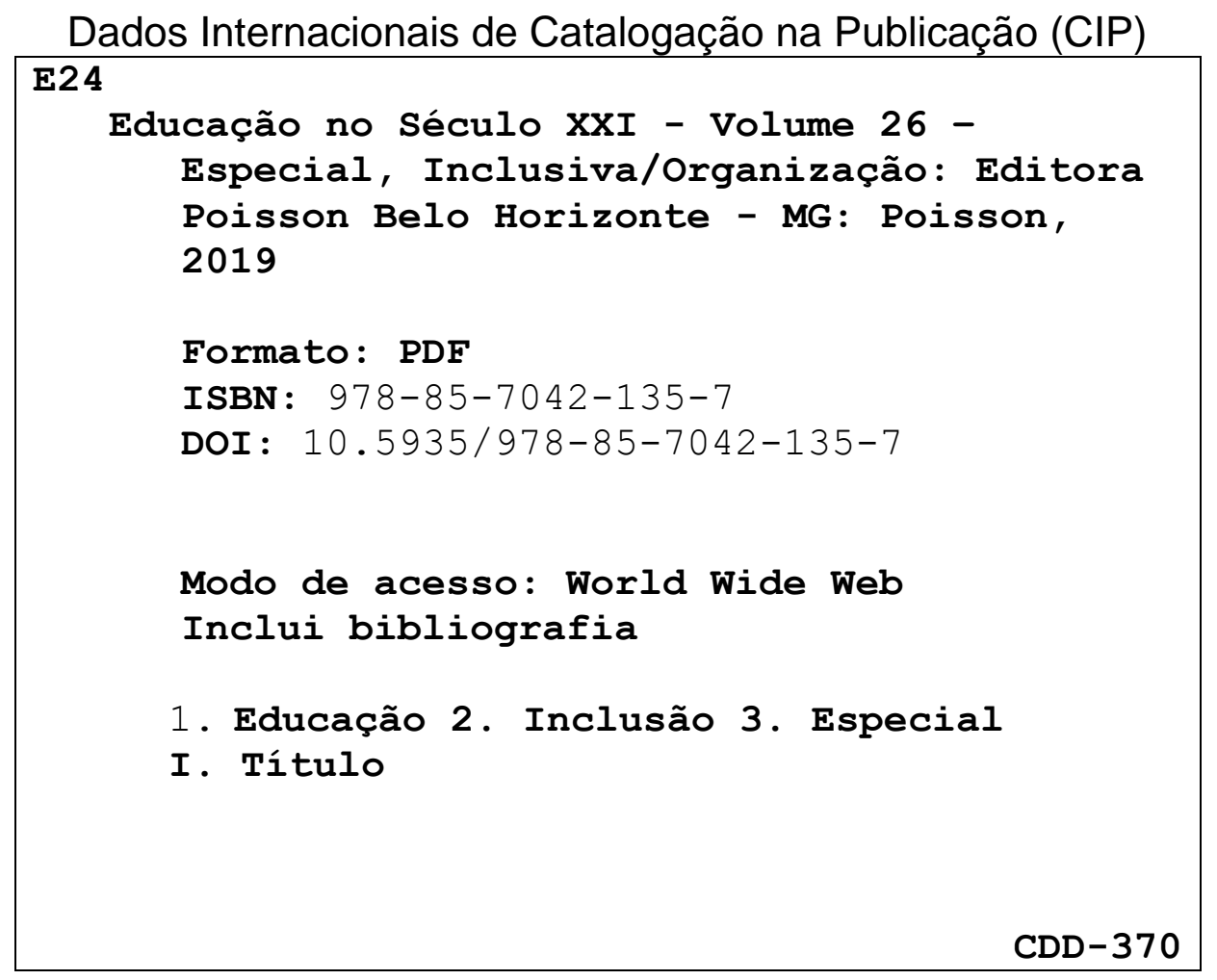

O conteúdo dos artigos e seus dados em sua forma, correção e confiabilidade são de responsabilidade exclusiva dos seus respectivos autores

$\underline{\text { www.poisson.com.br }}$

contato@poisson.com.br 


\section{SUMÁRIO}

Capítulo 1: A importância do assistente social na educação como instrumento de minimização das desigualdades sociais.

Maria Aparecida Pereira, Maria Goretti Rodrigues de Souza Oliveira, Maria de Lourdes Zacarias da Silva, Maria de Fátima leite Gomes

Capítulo 2: Educação inclusiva: experiências tecidas em espaços educacionais do ensino fundamental, médio, técnico profissionalizante e superior. 12

Eri Cristina dos Anjos Campos, Marines Dias Gonçalves, Lurdes Caron

Capítulo 3: A pessoa com deficiência no ensino superior: uma análise da produção acadêmica da UFMG.

Fernanda Costa Silva, Letícia Jafar da Fonseca, Eliane Marina Palhares Guimarães, Dayane Alves Barbosa, Jordana Rabelo Soares

Capítulo 4: As significações de educação especial e inclusiva em diferentes períodos da história da educação. 26

Marcia Raika e Silva Lima

Capítulo 5: A trajetória histórica dos estudos sobre o Autismo na criança: Contribuições da Psiquiatria e da Psicanálise. 35

Jaqueline Tubin Fieira, Giseli Monteiro Gagliotto

Capítulo 6: Estudante com transtorno do espectro do Autismo no ensino superior . 43 Eliene Nery Santana Enes, Renata Greco de Oliveira

Capítulo 7: Contribuição da mediação no desenvolvimento das funções cognitivas em pessoa com deficiência intelectual no âmbito empresarial 50

Glauce Virgínia M Régis, Dayse Aparecida Santos

Capítulo 8: 0 processo de inclusão de uma criança com paralisia cerebral: Significações a partir das interações socais no cotidiano de uma pré-escola. 54

Elton André Silva de Castro

Capítulo 9: 0 lúdico como possibilidade para a aprendizagem de crianças diagnosticadas com transtorno do déficit de atenção/hiperatividade (TDAH) certificado tutoria e o papel do tutor.. 60 


\section{SUMÁRIO}

Capítulo 10: "Tenho problema de cabeça, por isso não aprendo": Devolvendo o lugar de protagonismo a alunos medicalizados

Aline Frollini Lunardelli, Janaina da Cruz Martins Lizze, Mariana Santana Facina

Capítulo 11: Considerações acerca da I mostra de surdez e educação do IFMA Campus Viana - MA 75

Erika Patrícia Martins Ferreira, Maria do Socorro de Sousa

Maycon Cesar Pereira Wernz, Claudia de Oliveira Vale, Jodelma Castelo Branco Mendes, Sephora Santana Souza, Aline Antonia Santos Lins

Capítulo 12: Singularidade surda mesmo quando a Fonoaudiologia não quer e a educação não entende!...

Silvana Elisa de Morais Schubert, Ronaldo Quirino da Silva, Jefferson Diego de Jesus, Luiz André Brito Coelho, Marcelo Elisio Vasicki

Capítulo 13: Ensino de Português para criança surda na escola regular: Um estudo de caso ...... 89

Ana Carla Severo Andrade, Pascoal Eron Santos de Souza, Ricardo José Rocha Amorim

Capítulo 14: Inclusão de deficientes visuais na escola: Um paradoxo 96 Heloisa Valeria Mangia Torres, Maria Roselene Soares Marques

Capítulo 15: A contribuição do rádio para formação cidadã de pessoas com deficiência visual. 101

Rosane da Silva Nunes, Erlane Cristhynne Felipe dos Santos

Capítulo 16: Classe hospitalar: Promoção da condição humana 109 Aparecida Ramazotti de Camargo, Gláucia Pereira Lima Joaquim Braga, Mario César Alves Ferreira

Capítulo 17: Exercício artístico: Revistas e Lamentos, Grupo de Teatro Luz/Apadevi/Guarapuava

Eglecy do Rocio Lippmann

Capítulo 18: O Proeja na educação do campo: Uma análise curricular da disciplina de Educação Física. 119

Sâmmya Faria Adona Leite 


\section{SUMÁRIO}

Capítulo 19: Representações de si sobre o processo de alfabetização em alunos da educação de jovens e adultos.

Kelly Jessie Queiroz Penafiel, Valéria Leite da Silva

Capítulo 20: 0 perfil do estudante de educação de jovens e adultos na rede municipal de ensino de Viçosa/MG 138

Anmaly Natália Miguel Monteiro Gilbert, Eleusy Natália Miguel, Nádia Marota Minó

Capítulo 21: "Papagaio velho não aprende mais a falar": A educação humanística numa perspectiva libertadora. 144

Francinilda Rufino de Souza, Jomar Ricardo da Silva

Capítulo 22: A educação escolar como direito dos povos indígenas: A conquista das crianças Sateré- Mawé 152

Elenice Maria Farias Mourão de Menezes, Simone Souza Silva, Renner Douglas Gonçalves Dutra

Capítulo 23: Escolarização e objetos: a troca no sentido das miçangas entre os guaranimbyá do Rio de Janeiro. 158

Danielle Bastos Lopes

Capítulo 24: Protagonismo nas produções textuais de alunos quissamaenses: Um desafio para todos os envolvidos na educação 165

Edwilson da Silva Andrade, Martha Caroline Duarte de Brito Freitas

Capítulo 25: A educação física como instrumento de inclusão escolar. 172

Diego Soares Souza, Julianna Mendes de Matos Souza, Silvana Carolina Fürstenau dos Santos, Wylker Souza Saraiva, Glaydson de Oliveira Soares

Capítulo 26: Inclusão social e incentivo no processo de aprendizagem no brejo paraibano através das olimpíadas científicas.

Márcia Verônica Costa Miranda, Williams Alves Xavier

Autores: 


\section{Capítulo 1}

\section{A importância do assistente social na educação como instrumento de minimização das desigualdades sociais}

\section{Maria Aparecida Pereira \\ Maria Goretti Rodrigues de Souza Oliveira \\ Maria de Lourdes Zacarias da Silva \\ Maria de Fátima leite Gomes}

Resumo: Este artigo objetiva esclarecer a inserção e atuação do Assistente Social na Política de Educação brasileira, como importante agente transformador das situações de vulnerabilidade social encontradas na parcela da população escolar que convive com as diversas expressões da questão social e por essa razão sofre com intensidade os reflexos das desigualdades sociais. É apresentado em um breve relato histórico os primórdios da profissão do Assistente Social na divisão sociotécnica e sua inserção na área da educação, desmistificando a figura de mero coadjuvante nas arcaicas ações caritativas e trazendo à tona as reais alçadas e imputações do profissional do Serviço Social no seu novo papel de contribuir para a garantia de uma educação capaz de promover a justiça social e a minimização das desigualdades. Quando a Constituição Federal de 1988 estabelecera que a educação passasse a ter status de um direito social assegurado constitucionalmente, concomitante à criação dos Conselhos Federal e Regionais de Serviço Social (CFESS e CRESS), a presença do Assistente Social no âmbito da educação escolar possibilitou a abertura de espaços participativos democráticos envolvendo os três principais pilares para o bom desenvolvimento das políticas educacionais: a escola, a família e a comunidade.

Palavras Chave: Serviço Social, Educação Escolar, Desigualdades Sociais 


\section{INTRODUÇÃO}

O presente artigo está estruturado através de revisões bibliográficas, cujos dados foram coletados com base em artigos científicos. A fundamentação teórica está baseada em autores que relatam e centralizam as informações abordadas sobre o assunto em pauta. Para melhor dimensionar a importância do Serviço Social na educação, como veículo condutor de instrumentos contundentes para a minimização das desigualdades sociais e equalização de oportunidades para quem se encontra imerso nas intempéries da questão social, é necessário erradicar a visão estigmatizada e retrógrada que muitos associam ao Assistente Social como mero distribuidor de benefícios e executor das políticas sociais. 0 profissional de Serviço Social é, primordialmente, um agente crítico transformador e profundamente engajado nas lutas sociais, no acesso, na ampliação dos direitos sociais universais e na elaboração de ações de combate direto às diversas expressões da questão social.

O Conselho Federal de Serviço Social (CEFESS) em conjunto com os Conselhos Regionais de Serviço Social (CRESS) estabelecem as competências e as atribuições do profissional do serviço social na educação. Desse modo, elas estão intimamente interligadas com o Código de Ética do Profissional, a Lei de Regulamentação da Profissão e com as Diretrizes Curriculares da ABEPSS, os quais são o tripé do exercício profissional. Assim, a implantação do serviço social na política da educação se efetivou com a expansão das condições de acesso e permanência dos alunos nas instituições escolares, a partir do incremento de programas assistenciais. Esta inserção foi de fundamental importância para uma maior dinâmica do espaço escolar, espaço este que envolve três esferas fundamentais: a escola, a família e a comunidade.

\section{METODOLOGIA}

0 trabalho em tela baseia-se em procedimentos da pesquisa social, de caráter quali-quantitativo. Inicialmente, procedeu-se ao processo de revisão bibliográfica fundamentando-se em autores que relatam e centralizam as informações abordadas sobre o assunto em pauta para uma análise aprofundada do tema em questão.

0 presente estudo partiu do fato que apesar do assistente social estar inserido no âmbito educacional desde as protoformas do Serviço Social. É um profissional cuja atuação ainda continua sendo mal compreendida, interpretada de forma equivocada, fazendo-se necessário uma explanação mais aprofundada da importância do Serviço Social na educação principalmente como instrumento de minimização das desigualdades sociais, haja vista que, trata-se de um profissional que tem como objeto de trabalho a questão social com suas diversas expressões e estas se fazem presente de forma intensa no cotidiano da educação e precisam ser enfrentadas.

\section{RESULTADOS E DISCUSSÃO}

A desigualdade social constitui-se como problema social que está presente em todos os países do mundo, sendo mais evidenciada naqueles denominados subdesenvolvidos. Suas causas são as mais diversas, porém, diz respeito principalmente à má distribuição de renda, a falta de uma educação pública de qualidade, bem como a escassez de oportunidades no mercado de trabalho. A desigualdade social tem sua gênese no surgimento do modo de produção capitalista ${ }^{1}$, cuja ascensão se deu com a Revolução industrial.

Acerca dessa problemática, Netto (2007, p.5) fez a seguinte afirmativa:

Há poucos países, na América Latina e no mundo, que apresentam padrões de desigualdade social como os que se registram no Brasil _ não foi por outra razão, aliás, que o maior historiador marxista vivo anotou que o meu país, "monumento de injustiça social", é "candidato a campeão mundial de desigualdade econômica", uma vez que, segundo dados da entrada dos anos 90 do século passado, "os $20 \%$ mais pobres da população dividiam entre si $2,5 \%$ da renda total da nação, enquanto os $20 \%$ mais ricos ficavam com quase dois terços dessa renda".

\footnotetext{
${ }^{1}$ Consiste numa relação assalariada da produção, na qual o detentor dos meios de produção e da propriedade privada objetivam o lucro e para tanto beneficia-se do crescente exército de reserva para extrair a mais-valia daqueles que vendem sua força de trabalho para garantir a sua subsistência.
} 
Desta feita, o serviço social como profissão que tem como objeto de estudo as múltiplas expressões da questão social ${ }^{2}$, foi designado para mediar os conflitos entre capital $\mathrm{x}$ trabalho.

Para Pastorini (2007, p.16. apud PIANA 2009, p.22)

[...] o Serviço Social como uma das profissões responsáveis pela mediação entre Estado, burguesia e classe trabalhadora na implantação e implementação das políticas sociais destinadas a enfrentar a "questão social", que emergiu na primeira metade do século XIX, com o surgimento do pauperismo, na Europa Ocidental[...], ganha hoje, novos contornos a partir do complexo cenário formado pelos monopólios e pelo ideário neoliberal.

Em meados da década de 1930, o Serviço Social foi configurado como profissão inserida na divisão sociotécnica do trabalho. De acordo com Iamamoto (2007) o Serviço Social se apresentava como uma das alternativas às ações caritativas tradicionais, a partir de uma nova 'racionalidade' no enfrentamento da Questão Social. Neste contexto o cenário escolar entra no universo do Serviço Social devido à necessidade de haver um profissional de caráter assistencial que auxiliasse na dinâmica funcional das escolas, dificultada então pelas refrações da Questão Social.

Apenas após o movimento de reconceituação do Serviço Social, iniciado na década de 1980, com a aprovação da Constituição Federal de 1988, onde a educação passa a ser reconhecida constitucionalmente como um direito social, e a partir dos anos 2000, com a criação do Conselho Federal de Serviço Social (CFESS) e dos Conselhos Regionais de Serviço Social (CRESS), as questões relacionadas ao Serviço Social na Educação puderam ser amplamente debatidas, criando subsídios para a elaboração e execução de projetos de inclusão efetiva dos Assistentes Sociais na Política de Educação Escolar.

A partir do parecer jurídico número $23 / 2000^{3}$ e do Projeto de Lei no $3.688 / 2000^{4}$ o Serviço Social obteve respaldo para fortalecer as lutas sociais em defesa de uma democratização do espaço escolar.

A presença do profissional de Serviço Social nas escolas, de acordo com Vieira (2016), promove, através da abertura de espaços participativos democráticos, o estreitamento nas relações dos três eixos principais inerentes à realidade escolar: famílias, comunidade e a intituição de ensino. Esta integração possibilita a articulação com outras políticas públicas que possam atender às demandas que se apresentarem no exercício das ações elaboradas.

Conforme Almeida (2007), a participação dos assistentes sociais no ambiente escolar, em especial nas escolas de ensino fundamental, representa um dos principais objetivos dos profissionais da área em questão, para que possam exercer efetivamente sua atuação política e profissional na defesa dos direitos sociais e humanos. Além disto, representa a necessidade sócio-institucional inegável diante da Questão Social aflorada no âmbito do poder legislativo de diferentes Estados e municípios.

[...] o enfrentamento da Questão Social envolve a luta pela construção, materialização, e consolidação dos direitos sociais, como uma mediação para a construção de outra sociabilidade, ou seja, é através da mediação que o profissional tem condições de traçar um direcionamento à sua prática de forma crítica e não alienada, a partir do seu projeto ético-político, o que possibilita uma ação transformadora (PIANA, 2009, apud. VIEIRA, 2016).

A desigualdade social no âmbito educacional já demonstra sua intensificação, principalmente em se tratando do ensino secundário, que diz respeito à diferença da qualidade do ensino proporcionado àqueles cujas condições financeiras permitem ingressar em escolas privadas e os que estudam em escolas públicas. Esta situação de desigualdade é ainda mais agravada entre os estudantes de escolas públicas que vivem em extrema pobreza, onde lhes falta o mínimo para uma vida digna.

\footnotetext{
2 Por questão social, no sentido universal do termo, queremos significar o conjunto de problemas políticos, sociais e econômicos que o surgimento da classe operária provocou na constituição da sociedade capitalista. Logo, a questão social está fundamentalmente vinculada ao conflito entre capital e trabalho. (CERQUEIRA FILHO,1982, p.21 apud PIANA -p.53)

3 Parecer Jurídico solicitado pelo CFESS sobre a implantação do Serviço Social nas escolas da rede pública de Ensino Fundamental e Ensino Médio.

4 Dispõe sobre a introdução de assistente social no quadro de profissionais de educação em cada escola.
} 
Essa realidade é encontrada em diversos lares de alunos da periferia brasileira, que, na maioria das vezes, apresentam no seu cotidiano outras expressões da questão social, fazendo-se necessário ao assistente social que atua na educação, elaborar estratégias que viabilizem o acesso aos direitos das famílias que se encontram em situação de risco e vulnerabilidade social.

Desta forma, cabe ao profissional, não se deter na aparência, não culpabilizar o indivíduo, buscar a essência, a totalidade e através de encaminhamentos, procurar minimizar as diversas expressões da questão social que podem estar inseridas nas situações de desigualdade social, pois, conforme afirmado Albenaz e Silva (2019, p. 174)

[...] com o aparato de conhecimento, com a capacidade de intervenção na realidade, com a competência de investigar problemas sociais, com os grupos de convivências, com a formação de sujeitos políticos etc. são inúmeras possibilidades para estes profissionais: socializar informações; orientar a população quanto aos seus direitos; incentivar a participação dos sujeitos em organismos de lutas; fazer com que a ação do Assistente Social promova a mudança e assim se materialize em "uma nova ordem social" contrária as desigualdades e explorações, cuja ação é pautada na emancipação humana.

\section{CONCLUSÕES}

Destarte, o Serviço Social busca minimizar tais situações, tornando-se instrumento para esse fim. Até porque, todo cidadão precisa fazer valer os seus direitos, cabendo ao Estado o cumprimento, deste, contudo, no âmbito educacional, para a efetivação dos direitos, e o exercício da cidadania, é o assistente social que orienta, direciona e através de encaminhamentos e da rede socioassistencial, possibilita a viabilização do acesso ao que até então pode estar sendo negado ao aluno, bem como à sua família.

Marshall (1967, p. 73), acerca da relação da educação com a cidadania, afirma que:

A educação das crianças está diretamente relacionada com a cidadania, e, quando o Estado garante que todas as crianças serão educadas, este tem em mente, sem sombra de dúvida, as exigências e a natureza da cidadania. Está tentando estimular o desenvolvimento de cidadãos em formação. 0 direito à educação é um direito social de cidadania genuíno porque o objetivo da educação durante a infância é moldar o adulto em perspectiva. Basicamente, deveria ser considerado não como o direito da criança freqüentar a escola, mas como o direito do cidadão adulto ter sido educado. (sic).

Isso demonstra o quanto a educação é importante para a formação da cidadania, do conhecimento dos direitos, assim como o assistente social na educação é importante para minimizar as duras consequências das violações de direitos, os quais perpassam pela desigualdade social.

\section{REFERÊNCIAS}

[1] Almeida, Ney Luiz Teixeira de. O Serviço social na educação: novas perspectivas sócio-ocupacionais. In: Simpósio Mineiro de Assistentes Sociais, 2007, Belo Horizonte. Anais... Belo Horizonte: CRESS-6ª , 2007. Disponível em: <http://necad.paginas.ufsc.br/files/2012/07/0_Servico_Social_na_Educacao_perspectivas__ socio_ocupacionais1.>. Acesso em: 08/09/2017.

[2] Albernaz, Ana C. N.Peres; Silva, Valéria G. Costa. Assistente Social: um profissional a serviço dos direitos, da cidadania e da justiça social. Revista da Católica, Uberlândia, v. 1, n. 1, p. 166-175, 2009 - Disponpivel em: $<$ www.catolicaonline.com.br/revistadacatolica.> Acesso em: 09/Set /2017

[3] Conselho Federal de Serviço Social. GT Serviço Social na Educação. Brasília: CFESS/ CRESS, 2001.

[4] ___ Subsídios para atuação de assistentes sociais na Política de Educação. GT Serviço Social na Educação. Brasília: CFESS/CRESS, 2011.

[5] Brasil. Projeto de lei no 3.668, de novembro de 2000. Dispõe sobre a introdução de Assistente Social no quadro de profissionais de educação em cada escola. Disponível em: < http://imagem.camara.gov.br/Imagem/d/pdf/DCD02NOV2000.pdf\#page=121>. Acesso em: 08/09/2017.

[6] Iamamoto, Marilda Vilela. Relações sociais e serviço social no Brasil: esboço de uma interpretação históricometodológica. 20. ed. São Paulo: Cortez, 2007. 
[7] Marshall, T. Cidadania, classe social e status. Rio de Janeiro: Zahar, 1967.

[8] Netto; José Paulo; Desigualdade, pobreza e Serviço Social. Revista em Pauta, no19- Revista da Faculdade de Serviço Social da Universidade do Estado do Rio de Janeiro- 2007

[9] Piana, Maria Cristina. A construção do perfil do assistente social no cenário educacional. São Paulo: Cultura Acadêmica, 2009.

[10] Vieira, Maira Figueiredo. O serviço social na política de educação Escolar / Maira Figueiredo Vieira. Pouso Alegre: 2016. $122 \mathrm{f}$. 


\section{Capítulo 2}

Educação inclusiva: experiências tecidas em espaços educacionais do ensino fundamental, médio, técnico profissionalizante e superior

\section{Eri Cristina dos Anjos Campos}

Marines Dias Gonçalves

Lurdes Caron

Resumo: 0 presente artigo trata de um relato que objetiva descrever sobre duas experiências pedagógicas vivenciadas pelas pesquisadoras ao longo do trabalho desenvolvido em prol da inclusão educacional de estudantes com deficiência, transtornos globais do desenvolvimento e altas habilidades/superdotação. Neste sentido, apresentamos a trajetória das Salas de Atendimento Educacional Especializado (AEE), no ensino fundamental, das escolas municipais da cidade de Lages desde sua implantação em 2007 até os dias atuais. Na sequencia, as experiências vivenciadas pelo Núcleo de Atendimento a Pessoas com Necessidades Específicas (NAPNE), no ensino médio, técnico profissionalizante e superior do Instituto Federal Catarinense - Campus Rio do Sul, frente à proposta de inclusão defendida em seu regulamento. Destacamos que, mediante a implantação pelo Ministério da Educação, da Política Nacional de Educação Especial na Perspectiva da Educação Inclusiva, em 2008, esta educação passa a ser entendida como um direito humano de todo o cidadão ao acesso à escola e a uma educação que respeite as diferenças e os valores de cada estudante e de cada cultura. Assim, para realização da pesquisa que relata as experiências, exploramos documentos que norteiam o trabalho desenvolvido pelo AEE e NAPNE e está fundamentada na legislação pertinente e em teóricos que discutem e problematizam a temática. A partir das leituras, das políticas públicas, e reflexão sobre as práticas vivenciadas, identificamos as principais diferenças e aproximações entre as duas experiências. Na perspectiva da inclusão percebemos que muitos são os desafios enfrentados no cotidiano dos trabalhos realizados no AEE e NAPNE de modo a superar processos excludentes da educação.

Palavras-chave: Educação Especial, Educação Inclusiva, Ensino Fundamental, Ensino Médio e Técnico. Ensino Superior. 


\section{INTRODUÇÃO}

Historicamente, os termos inclusão, nos dias de hoje, têm ocupado cada vez mais espaço nos discursos políticos e debates sociais e na imprensa falada e escrita. Entretanto, cumpre ressaltar que, no Brasil, o termo inclusão no contexto da Educação Especial se dá a partir da década de 1990.

Dentre os marcos legais, destacamos que a Política Nacional de Educação Especial na Perspectiva da Educação Inclusiva ${ }^{5}$ (MEC, 2008), define como objetivo o acesso, a participação e a aprendizagem dos estudantes com deficiência, transtornos globais do desenvolvimento e altas habilidades/superdotação no ensino regular, desafiando os sistemas de ensino a gerarem respostas educativas às necessidades educacionais destes estudantes.

Neste novo modelo, os sistemas educacionais avaliam seus conceitos e, constroem novos saberes adaptando-se às exigências de uma escola inclusiva, sem negar as dificuldades dos estudantes e sim, estimular suas potencialidades.

Com a inclusão educacional, as diferenças no meio escolar, entre os estudantes com deficiência, transtornos globais do desenvolvimento e altas habilidades/superdotação e os demais, são vistas a partir do contexto social, que pode ampliar a visão de mundo e aumentar as experiências de convivência entre todos os estudantes.

Deste modo, o trabalho aqui desenvolvido, objetiva descrever duas experiências pedagógicas na perspectiva da Educação Inclusiva: Sala de Atendimento Educacional Especializado, no ensino regular do município de Lages e Núcleo de Atendimento a Pessoas com Necessidades específicas, no ensino médio técnico e profissionalizante e ensino superior do município de Rio do Sul, ambos do Estado de Santa Catarina.

Assim, compreendendo o desafio que representa a Educação Inclusiva, no sentido de uma educação para todos e todas, em um mesmo contexto escolar, percebemos a necessidade de repensar nossas práticas pedagógicas e propor alternativas que problematizem modelos excludentes de educação.

\section{REFERENCIAL TEÓRICO}

Ao longo das últimas décadas, foram reconstruídas, novas perspectivas políticas, econômicas e sociais quanto ao entendimento de estudantes com deficiência, transtornos globais do desenvolvimento e altas habilidades/superdotação e a sua inclusão na escola. A reflexão sobre este tema está sendo ampliado cada vez mais entre os professores e a sociedade. Para tanto, exige diferentes formas de desenvolvimento de estudos e de práticas pedagógicas inovadoras que favoreçam a inclusão.

Em nosso país, dentre os pressupostos legais, destacam-se a Constituição Federal (CF) de 19886, no Capítulo III, o qual no seu Artigo 206 estabelece em um de seus princípios, que o ensino será ministrado em "igualdade de condições de acesso e permanência na escola" e no Artigo 208 a Oferta de "Atendimento Educacional Especializado, preferencialmente na rede regular de ensino".

A Lei de Diretrizes e Bases 9.394/967, no seu Artigo 59, inciso I, aponta que os sistemas de ensino precisam assegurar aos educandos com necessidades especiais, "currículos, métodos, técnicas, recursos educativos e organização específicos, para atender às suas necessidades".

A meta quatro da Lei no 13.005 , de 25 de junho de 2014 , aponta a universalização "para a população de quatro a dezessete anos com deficiência, transtornos globais do desenvolvimento e altas habilidades ou superdotação, o acesso à educação básica e ao atendimento educacional especializado, preferencialmente na rede regular de ensino".

\footnotetext{
5 BRASIL. Política Nacional de Educação Especial na Perspectiva da Educação Inclusiva. Brasília. Ministério da Educação. Brasília, janeiro de 2008. Disponível em: < http://portal.mec.gov.br/arquivos/pdf/politicaeducespecial.pdf>. Acesso em: 08 ago. 2015.

6 BRASIL, Constituição da República Federativa do Brasil de 1988. Brasília, 1988. Disponível em:

http://www.planalto.gov.br/ccivil_03/constituicao/constituicaocompilado.htm, Acesso em: 07 ago. 2015.

7 BRASIL, Lei no 9.394, de 20 de dezembro de 1996. Brasília, 1996. Disponível em:

http://www.planalto.gov.br/ccivil_03/LEIS/L9394.htm. Acesso em: 07 ago. 2015

8 BRASIL, Lei no 13.005, de 25 de junho de 2014. Brasília, 2014. Disponível em:

http://www.planalto.gov.br/ccivil_03/_ato2011-2014/2014/lei/l13005.htm. Acesso em: 07 ago. 2015
} 
Entretanto, mesmo com todo o aparato legal, é comum entre os profissionais da educação, na presença de estudantes com deficiência, transtornos globais do desenvolvimento e altas habilidades/superdotação se sentirem desafiados em seus saberes pedagógicos e apresentarem condutas que ora se afastam, ora se aproximam das concepções presentes nas normativas legais relativas à inclusão.

Neste sentido, destaca-se que estudantes com deficiência, transtornos globais do desenvolvimento e altas habilidades/superdotação precisam ser atendidos nas suas especificidades, articulando-se dentre outros encaminhamentos, ações entre a Educação Especial e o Ensino Regular.

Face ao exposto e mediante a perspectiva da Educação Inclusiva, entende-se que:

a Educação Especial passa a integrar a proposta pedagógica da escola regular, promovendo o atendimento às necessidades educacionais especiais de alunos com deficiência, transtornos globais de desenvolvimento e altas habilidades/superdotação. Nestes casos e outros, que implicam em transtornos funcionais específicos, a Educação Especial atua de forma articulada com o ensino comum, orientando para o atendimento às necessidades educacionais especiais desses alunos (MEC/SEESP, 2010, p. 20).

\section{METODOLOGIA ADOTADA}

O presente trabalho é uma investigação de abordagem qualitativa, em que buscamos descrever, refletindo sobre duas experiências educacionais consideradas inclusivas: Sala de Atendimento Educacional Especializado, no município de Lages e Núcleo de Atendimento a Pessoas com Necessidades específicas, no município de Rio do Sul.

Por abordagem qualitativa, Chizzotti (2001, p. 79), entende que "há uma relação entre o mundo real e o sujeito", uma conexão em meio ao "mundo objetivo e a subjetividade do sujeito", sendo necessária uma relação de cumplicidade entre o pesquisador e o sujeito pesquisado.

Descrevemos um relato de experiência sobre Educação Inclusiva, a partir da percepção e das vivências educacionais das pesquisadoras a frente do AEE (Lages) e NAPNE (Rio do Sul). A pesquisa está fundamentada em alguns autores que tratam da Educação Inclusiva e, em fontes documentais.

\section{ATENDIMENTO EDUCACIONAL ESPECIALIZADO: UMA FERRAMENTA DE INCLUSÃO NAS ESCOLAS MUNICIPAIS DE LAGES-SC}

Por meio do Plano de Desenvolvimento da Educação - PDE, do Ministério da Educação no ano de 2007, foi lançada nos sistemas educacionais brasileiros, a implantação das Salas de Recursos Multifuncionais (SRM). Paralelamente com estas salas o AEE, como um serviço da Educação Especial, toma seu espaço nas escolas de ensino regular com o objetivo de contribuir para a transformação dos sistemas educacionais em inclusivo.

Este serviço da Educação Especial é entendido por Alves (2006, p. 13), como:

as salas de recursos multifuncionais são espaços da escola onde se realiza o atendimento educacional especializado para alunos com necessidades educacionais especiais, por meio do desenvolvimento de estratégias de aprendizagem, centradas em um novo fazer pedagógico que favoreça a construção de conhecimentos pelos alunos, subsidiando-os para que desenvolvam o currículo e participem da vida escolar.

Em conformidade com a Política Nacional da Educação Especial na Perspectiva da Educação Inclusiva (2007), o município de Lages neste mesmo ano implantou sua primeira SRM com AEE.

Por meio do Censo Escolar, o Ministério da Educação (MEC) sinalizou a necessidade de inserir este atendimento na Escola Municipal de Ensino Básico Waldo Costa - EMEB, localizada em um bairro periférico da cidade devido ao número elevado de estudantes com deficiência.

A EMEB Waldo Costa tornou-se escola polo para atender estudantes vinculados diretamente a ela e também estudantes com deficiência, Transtornos globais do desenvolvimento, altas habilidades/superdotação das unidades escolares de sua região. 
Somente no ano de 2009, foram selecionadas mais cinco escolas localizadas em pontos extremos da cidade de Lages, SC, abrangendo um número maior de atendimentos para estudantes público alvo da Educação Especial, matriculados no ensino regular.

Assim gradativamente, a cada ano as escolas municipais de Lages vêm sendo beneficiadas com salas de recursos que desenvolvem um trabalho articulado com a sala de aula do ensino regular, buscando atender as especificidades de cada estudante atendido pelo AEE. Atualmente Lages conta com o serviço do AEE em 16 escolas municipais.

Cabe ressaltar que 15 dessas escolas são equipadas com materiais das salas tipo I e somente uma com recursos para tipo II, sendo específicos das salas tipo I recursos que atendam todas as deficiências, Transtornos globais do desenvolvimento, altas habilidades/superdotação, com exceção do estudante cego. A sala tipo II, atende todos os estudantes da Educação Especial inclusive o cego, pois esta além de ter todos os equipamentos da sala tipo I, também tem recursos específicos para esta deficiência.

0 trabalho do AEE vem cada vez mais ganhando espaço nas escolas municipais de Lages. A cada ano o número de estudantes pertencentes a este atendimento aumenta significativamente, em decorrência dos estudantes com deficiências, Transtornos globais do desenvolvimento, altas habilidades/superdotação estarem ocupando seu lugar de direito no ensino regular.

\section{FORMAÇÃO DE PROFESSORES PARA O AEE DAS ESCOLAS MUNICIPAIS DE LAGES}

A formação do professor está consecutivamente presente nas propostas educacionais, é uma temática discutida pelos professores em diferentes espaços de formação como as universidades, as secretarias de educação e no próprio ambiente escolar.

A formação do professor para atuação no AEE requer condições que o habilite para esta função. A Educação Especial na perspectiva inclusiva exige que este professor tenha formação inicial e/ou continuada tendo em vista a inclusão escolar dos estudantes com deficiências, transtornos globais do desenvolvimento, altas habilidades/superdotação.

para atuar na Educação Especial, o professor deve ter como base da sua formação, inicial e continuada, conhecimentos gerais para o exercício da docência e conhecimentos específicos da área. Essa formação possibilita a sua atuação no atendimento educacional especializado, aprofunda o caráter interativo e interdisciplinar da atuação nas salas comuns do ensino regular, nas salas de recursos, nos centros de atendimento educacional especializado (BRASIL, 2015) ${ }^{9}$.

Os professores do AEE das escolas municipais Lages-SC, possuem habilitações diferenciadas na área da Educação Especial. Alguns com formação inicial em Educação Especial e outros com especialização em AEE e todos realizam frequentemente formações continuadas nesta área.

Atualmente no contexto da Rede Municipal de Ensino de Lages, a formação continuada desses professores acontece por meio de atividades realizadas pela Secretaria de Educação do município de Lages, nas universidades locais, com cursos a distancia oferecidos pelo MEC e conforme as necessidades de cada professor procura-se aperfeiçoamento com recursos próprios.

A oferta do Atendimento Educacional Especializado e a implantação de salas de recursos multifuncionais nas escolas municipais de Lages, foi definida pelo MEC/SEESP como município polo de algumas cidades de Santa Catarina, teve por um tempo a função de repassar para esses municípios formações disponibilizadas pelo MEC. Dessa forma, Lages recepcionou os municípios para os seminários Educação Inclusivos: Direito à Diversidade que aconteceram nos anos de 2010 a 2013.

Em 2014 a proposta de formação continuada seguiram novos encaminhamentos do MEC/SECADI, sendo especificado que somente o responsável pela Educação e Especial de cada município participaria das formações com local e data estabelecidas por esta secretaria, sendo que este profissional da área da educação será um multiplicador em sua cidade.

\footnotetext{
9 BRASIL, Política Nacional de Educação Especial na Perspectiva da Educação Inclusiva, Documento elaborado pelo Grupo de Trabalho nomeado pela Portaria Ministerial no 555, de 5 de junho de 2007, prorrogada pela Portaria no 948, de 09 de outubro de 2007. Disponível em: http://peei.mec.gov.br/arquivos/politica_nacional_educacao_especial.pdf, acesso em 07agos. 2015.
} 
Para que se possa encontrar crescimento profissional, superar os obstáculos cotidianos e a compreender as diferenças encontradas em uma sala de aula, faz-se necessário que a formação do professor seja contínua e processual. Não se pode pensar em um único modelo de formação, mas que estes momentos sejam reflexivos para sua prática, compreendendo o ato educativo como uma ação social e política.

\section{NÚCLEO DE ATENDIMENTO ÀS PESSOAS COM NECESSIDADES ESPECÍFICAS}

0 Núcleo de Atendimento às Pessoas com necessidades específicas - Napne refere-se a um grupo de pessoas que se organizaram para planejar e desenvolver ações destinadas à inclusão educacional de estudantes com necessidades específicas no âmbito do Instituto Federal Catarinense - IFC campus Rio do Sul.

Cumpre destacar que inicialmente, estes núcleos, foram criados e passaram a implementar ações, como medida para atender uma proposição do Programa de Educação, Tecnologia e Profissionalização para Pessoas com Necessidades Especiais (TEC NEP) ${ }^{10}$.

Com o entendimento de que a igualdade de oportunidades na educação profissional e no acesso ao trabalho constitui-se como direito e tarefa de todos. 0 programa TEC NEP, criado em 2000, apresentava como pressuposto a concepção de que compartilhar o conhecimento socialmente construído e inserir-se produtivamente na sociedade é um direito também das pessoas com deficiência, Transtornos globais do desenvolvimento, altas habilidades/superdotação.

No IFC- Campus Rio do Sul, o Napne foi criado em 2005. Desde então, busca articular ações destinadas à inclusão, $\mathrm{Na}$ medida em que foi se consolidando, envolveu de forma direta e indireta, diferentes atores sociais, tais como: psicólogos, supervisores, orientadores educacionais, técnicos administrativos, enfermeiras, fonoaudiólogo, fisioterapeuta, docentes, discentes e pais.

O Conselho Superior do Instituto Federal Catarinense (CONSUPER), que dispõe sobre o regulamento atual do Napne, define na Resolução nº 083/201411, Art. 2º , item I, sobre o que se entende por inclusão :

(...) assegurar a inserção nesta instituição a pessoas que apresentam déficits de toda ordem, permanentes ou temporários, mais graves ou menos severos. É garantir a pessoas com necessidades educacionais específicas, o recebimento de uma educação centrada no respeito e valorização das diferenças, satisfazendo as necessidades de todos, sejam quais forem as suas características físicas, psicológicas ou sociais (CONSUPER, 2014).

Segundo da Resolução n⿳0 083/2014, Art. 2º̣, no item II, entende-se por Necessidades Educacionais Específicas, "toda e qualquer condição que gere dificuldade significativa nas capacidades físicas, intelectuais e de aprendizagem ou mesmo sociabilidade ou interação social”.

Os participantes que compõe o Napne permanecem no grupo cerca de dois anos. Após este período, os mesmos podem ser reconduzidos por mais dois anos. A participação e o trabalho desenvolvido são voluntários.

A organização administrativa da equipe, bem como as finalidades, atribuições, competências do Napne é realizada tendo em vista o regulamento supracitado. Deste modo, dentre os componentes, a equipe conta com um coordenador, vice-coordenador e secretário, eleitos pelos próprios pares.

Em relação à capacitação das pessoas que compõe o Napne, após a implantação, no ano de 2005, um componente do grupo foi convidado a participar de especialização na área da Educação Inclusiva. Uma vez capacitado, este foi incumbido de repassar os conhecimentos para os demais participantes do Napne. No ano de 2013, houve uma capacitação à distância destinada a um número maior de componentes do núcleo.

10 O TEC NEP - atualmente é entendido como uma ação coordenada pela Secretaria de Educação Profissional e Tecnológica do Ministério da Educação que visa à inserção das Pessoas com Necessidades Educacionais Específicas PNE - (deficientes, superdotados/altas habilidades e com transtornos globais do desenvolvimento) em cursos de formação inicial e continuada, técnicos, tecnológicos, licenciaturas, bacharelados e pós-graduações da Rede Federal de Educação Profissional, Científica e Tecnológica, em parceria com os sistemas estaduais e municipais de ensino.

11 SANTA CATARINA, Resolução no 083 - Consuper/2014, Blumenau, out. 2014. Disponível em:

http://ifc.edu.br/wp-content/uploads/2014/11/RESOLU\%C3\%87\%C3\%830-083-2014-Aprova-Regulamento-

NAPNE.pdf. Acesso em 10 ago. 2015. 
Atualmente, dentre as finalidades do Napne existe a intenção de promover na instituição a cultura da educação para a inclusão, buscando a quebra de barreiras atitudinais, educacionais e arquitetônicas.

Fazendo um resgate das atividades realizadas pelo Napne, no período de 2010 a 2014, identificamos elementos relevantes para reflexões críticas a respeito da educação na perspectiva da inclusão.

Em 2010, o passo inicial do Napne foi tentar estabelecer entre o grupo o compromisso com a inclusão de estudantes com necessidades específicas, buscando a sensibilização dos componentes principalmente mediante a socialização de conhecimentos, ideias, discussões e relatos de experiências.

Em seguida, o Napne fez um levantamento da realidade da inclusão na instituição de ensino, identificando os estudantes considerados com necessidades específicas que já possuíam diagnóstico clínico. Estes se preocupavam em realizar os encaminhamentos que julgavam pertinentes. Assim, o planejamento das ações do Napne seguia a partir da análise das demandas a serem atendidas com informações obtidas, principalmente junto ao Núcleo Pedagógico da instituição, secretaria escolar e conselho de classe dos professores. Deste modo, inicialmente discutia-se no grupo as ações necessárias para atender a realidade da escola, designando entre a equipe quem seria responsável por fazer a mediação junto aos professores, pais, estudantes ou comunidade externa. Na sequência, o plano de ações passava a ser executado.

Destacamos abaixo algumas das ações desenvolvidas pelos integrantes do Napne em parceria com professores, técnicos, acadêmicos das licenciaturas, estudantes do ensino médio: Palestras de sensibilização a comunidade escolar em relação à inclusão; Realização de Seminários; Realização de Oficinas: Libras, Português como segunda língua para Surdos, Signwriting - Escrita de Sinais, Braille, Educação Inclusiva; Encaminhamentos relacionados a adaptações arquitetônicas; Aquisição de recursos materiais para sala do Napne e para o projeto Equoterapia; Assessoria pedagógica em relação à inclusão de estudantes com necessidades específicas; Participação em eventos de formação na área de Educação Inclusiva e desenvolvimento de Projetos.

No que se refere a práticas consideradas inclusivas, reconhecemos a necessidade de constantemente refletirmos sobre as ações realizadas, os desafios e fragilidades a serem superadas.

\section{PRINCIPAIS DESAFIOS}

Diante das considerações elencadas anteriormente, apontamos os principais desafios encontrados no decorrer das atividades realizadas pelo Napne e perceber de que forma eles se relacionam com a proposta da educação na perspectiva inclusiva.

A começar pela adesão e composição do grupo, percebemos que essa, aparentemente acontecia por sensibilidade à causa ou por proximidade com o tema. Deste modo, alguns até se colocavam a disposição, mas não apareciam nas reuniões e nem sempre ajudavam nos encaminhamentos solicitados. 0 fato de $o$ trabalho ser voluntário também desmotivou alguns integrantes.

As atividades e reuniões ocorriam durante o período de expediente do trabalho. Desta maneira, alguns integrantes do núcleo nem sempre conseguiam participar de todas as reuniões e encaminhamentos.

Durante as reuniões, os principais desafios enfatizados pelo grupo era a necessidade de envolver e fazer com que toda a instituição se comprometesse com a inclusão educacional de estudantes com necessidades específicas, pois se entendia que a responsabilidade não poderia recair exclusivamente sob um núcleo.

A capacitação é outro ponto frágil que desafia as atividades realizadas pelo núcleo, Assim, em alguns momentos sentíamos falta de uma equipe multiprofissional realmente atuante e capacitada. Além disso, percebia-se a necessidade de capacitação não somente dos integrantes do Napne, mas dos demais atores sociais que compunham a comunidade escolar.

Assim, na esfera do discurso político ideológico do Napne, percebemos o desafio que representa a concretude do discurso oriundo de uma política pública que se diz "inclusiva". Se o objetivo é dar suporte as práticas de Educação Inclusiva desenvolvidas pela escola, avanços se fazem necessários, principalmente em relação à formação continuada dos profissionais envolvidos no processo.

\section{CONSIDERAÇÕES FINAIS}

Com base nos vários elementos apresentados e desafios em torno da educação na perspectiva da inclusão de estudantes com deficiência, transtornos globais do desenvolvimento e altas habilidades/superdotação, 
entendemos que esta necessita sair do papel e ser assumida em todos os segmentos da sociedade, de forma que a escola consiga garantir o direito de todas as pessoas à educação.

0 relato das duas experiências dá condições de perceber que embora tenhamos as mesmas políticas públicas, a partir dos mesmos aspectos legais há pontos comuns e diferentes nas práticas e concepções pedagógicas.

Destacamos como pontos comuns o trabalho desenvolvido dentro do ensino regular e a proposta de inclusão como forma de educação para todos.

Como pontos diferentes Lages traz o trabalho do AEE realizado em uma sala de Recursos Multifuncionais com um professor com formação na área da Educação Especial, vinculando seu trabalho na sala de aula junto ao professor regente e o professor de apoio à inclusão. 0 trabalho do Napne em Rio do Sul acontece dentro de um Núcleo constituído por profissionais da educação e da área clínica.

Por fim concluímos que com a realização deste trabalho é possível dialogar; partilhar experiências; vivenciar outros contextos sociais e níveis de ensino e com eles aprender e respeitar as diferenças. Percebemos que tanto em Rio do Sul como no município de Lages, o esforço é comum no desenvolvimento de um trabalho de inclusão com estudantes que apresentam deficiência transtornos globais do desenvolvimento e altas habilidades/superdotação.

\section{REFERÊNCIAS}

[1] Alves, Denise de Oliveira. Sala de recursos multifuncionais: espaços para atendimento educacional especializado / elaboração Denise de Oliveira Alves, Marlene de Oliveira Gotti, Claudia Maffini Griboski, Claudia Pereira Dutra - Brasília: Ministério da Educação, Secretaria de Educação Especial, 2006.

[2] Brasil, Constituição da República Federativa do Brasil de 1988. Brasília, 1988. Disponível em: http://www.planalto.gov.br/ccivil_03/constituicao/constituicaocompilado.htm, acesso em: 07 ago. 2015.

[3] Brasil, Lei n ${ }^{\circ} 13.005$, de 25 de junho de 2014. Brasília, 2014. Disponível em:

http://www.planalto.gov.br/ccivil_03/_ato2011-2014/2014/lei/113005.htm. acesso em: 07 ago. 2015.

[4] Brasil, Lei no 9.394, de 20 de dezembro de 1996. Brasília, 1996. Disponível em: http://www.planalto.gov.br/ccivil_03/LEIS/L9394.htm. Acesso em: 28 jul. 2015.

[5] Brasil, Política Nacional de Educação Especial na Perspectiva da Educação Inclusiva, Documento elaborado pelo Grupo de Trabalho nomeado pela Portaria Ministerial no 555, de 5 de junho de 2007, prorrogada pela Portaria $\mathrm{n}^{\circ}$ 948, de 09 de outubro de 2007. Disponível em: http://peei.mec.gov.br/arquivos/politica_nacional_educacao_especial.pdf, acesso em 07agos. 2015.

[6] Brasil. Ministério da Educação. Secretaria de Educação Especial. Marcos Político-Legais da Educação Especial na Perspectiva da Educação Inclusiva.- Brasília: Secretaria de Educação Especial, 2010.

[7] Brasil. Política Nacional de Educação Especial na Perspectiva da Educação Inclusiva. Brasília. Ministério da Educação. Brasília, janeiro de 2008. Disponível em: < http://portal.mec.gov.br/arquivos/pdf/politicaeducespecial.pdf>. Acesso em: 08 ago. 2015.

[8] Chizzotti, Antonio. Pesquisa em ciências humanas e sociais. 5o edição. São Paulo: Cortez 2001.

[9] Santa Catarina, Rresolução no 083 - Consuper/2014, Blumenau, out. 2014. Disponível em: http://ifc.edu.br/wpcontent/uploads/2014/11/Resolu\%C3\%87\%C3\%83O-083-2014-Aprova-Regulamento-Napne.pdf. Acesso em 10 ago. 2015. 


\section{Capítulo 3}

\section{A pessoa com deficiência no ensino superior: Uma análise da produção acadêmica da UFMG}

\section{Fernanda Costa Silva}

Letícia Jafar da Fonseca

Eliane Marina Palhares Guimarães

Dayane Alves Barbosa

Jordana Rabelo Soares

Resumo: 0 trabalho a seguir retrata o estado da arte da produção acadêmica - Teses e Dissertações - da Universidade Federal de Minas Gerais que abordou estudos sobre inclusão e participação de alunos com deficiência no Ensino Superior. Considerou-se, também, trabalhos sobre a implementação da Lei de Cotas nas Instituições Federais de Ensino Superior (IFES). A proposta enfatizou o resgate de pesquisas de forma a auxiliar o processo organizacional da inclusão de pessoas com deficiência em ambientes de aprendizagem e de socialização. Foram realizadas análises de 14 trabalhos disponíveis na base de dados do Sistema de Bibliotecas da UFMG, que foram agrupados nas temáticas: 1.Metodologias de ensino para pessoa com deficiência com uso ou não de Tecnologia; 2.Inclusão Social da pessoa com deficiência no Ensino Superior/Trabalho; 3.Implementação da Lei de Cotas. Nas considerações finais, destacou-se que os trabalhos realizados sobre metodologias podem auxiliar o desenvolvimento de estratégias institucionais para atender estudantes cotistas com deficiência. Reforçou, por fim, a necessidade de se realizar reflexões sobre a historicidade vivenciada pelo público cotista para que sejam envidados esforços no sentido de implementar a legislação e propiciar a permanência desse público no ambiente universitário.

Palavras-chave: Alunos com deficiência. Ensino Superior. Cotas. Produção acadêmica. Inclusão. 


\section{INTRODUÇÃO}

A promulgação da Lei no 13.409, de 28 de dezembro de 2016, ocasionou uma série de desafios para as Instituições Federais de Ensino Superior (IFES) ao incluir a pessoa com deficiência na percentagem de vagas destinadas aos cotistas delimitados pela Lei de Cotas (Lei no 12.711 de 29 de agosto de 2012).

As estratégias a serem tomadas para a implementação da Lei deverão envolver, principalmente, aquelas com o intuito de garantir a acessibilidade e permanência desses alunos nas instituições, desafios estes também enfrentados em outros níveis de ensino (PLETSCH; LEITE, 2017). Espera-se que o dispositivo eleve a cada ano a inserção de pessoas com deficiência nas instituições federais de ensino, acarretando também alterações nas atividades cotidianas (PETTEN et al., 2017).

Neste contexto, os direitos das pessoas com deficiência é tema discutido no cenário nacional e internacional desde os anos 90. No Brasil, a Constituição de 1988 possibilitou uma expansão municipal para atendimento dos alunos com necessidades educacionais especiais e no ano de 1990, ao aceitar os termos da Declaração de Educação para Todos da Conferencia Mundial sobre Educação (Jomtien/Tailândia), o Governo comprometeu-se a estabelecer um sistema educacional mais inclusivo (MEC, 2002).

O Ministério da Educação (2010) considera como marcos regulatórios para a inclusão educacional a Política Nacional de Educação Especial na Perspectiva da Educação Inclusiva; o Decreto no 5.571/2008, que dispõe sobre atendimento educacional especializado complementar ao ensino regular para os alunos público alvo da educação especial e dá outras providências; o Decreto no $6.949 / 2009$, que ratifica a Convenção da ONU sobre os Direitos das Pessoas com Deficiência e a Resolução 04/2009 do Conselho Nacional de Educação que institui as Diretrizes Operacionais para o Atendimento Educacional Especializado na Educação Básica, modalidade Educação Especial.

Mesmo depois de decorridos quase 30 anos do início das discussões sobre a acessibilidade no ensino, fazse necessária a investigação do tema, a fim de minimizar ou eliminar barreiras para a inserção e permanência desta parcela da população nas IFES. Estudos sobre esse aspecto apontam que a política de cotas nas IFES ainda está em fase de implementação, e a inclusão da pessoa com deficiência no ensino foi reconhecida com maior destaque, mediante a Política Nacional de Educação Especial na Perspectiva da Educação Inclusiva, a partir do ano de 2008 (MAGALHÃES; SEVERINO, 2017; PLETSCH; LEITE, 2017).

Assim, a presente análise considerou que os estudos do tema podem auxiliar as IFES a promoverem reflexões acerca das alternativas de auxílio à condução organizacional para inclusão de pessoas com deficiência em ambientes de aprendizagem e de socialização. Dessa forma, o objetivo deste estudo foi retratar o estado da arte da produção acadêmica -Teses e Dissertações- da Universidade Federal de Minas Gerais (UFMG) que abordou pesquisas sobre inclusão e participação de alunos com deficiência no Ensino Superior, bem como a implementação da Lei de Cotas nas IFES. Especificamente, discutir os temas já estudados em pesquisa de egressos como apoio às estratégias e políticas internas para inclusão e acessibilidade dos alunos com deficiência na UFMG.

Os cenários revelados com estudos dessa natureza propõem resgatar e socializar pesquisas para expor os resultados à sociedade na tentativa de evitar que fiquem restritos às "prateleiras das bibliotecas das universidades" (FERREIRA, 2002, p. 260).

\section{METODOLOGIA}

A discussão do tema foi realizada de forma qualitativa, delimitando-se como campo de investigação o levantamento das produções acadêmicas disponíveis na Base de Dados de Teses e Dissertações do Sistema de Bibliotecas da UFMG.

Fundamentou-se o estudo no corpus analítico total das produções acadêmicas (Teses e Dissertações) da UFMG e disponíveis em meio eletrônico, utilizando-se dos descritores associados à busca com as expressões: pessoas com deficiência no ensino superior; acessibilidade no ensino superior; Lei de Cotas; ensino para pessoas com deficiência; ensino necessidades especiais; educação superior inclusiva.

Foram localizados trinta e nove trabalhos que abordaram a temática e/ou expressões de busca. Descartouse da discussão 16 trabalhos por não constar o arquivo digital na base de dados. Após apreciação dos demais trabalhos, fez-se necessária a realização de outra triagem, descartando-se mais nove trabalhos por não estarem relacionados ao estudo aqui proposto. 
Dessa forma, a presente análise foi realizada, utilizando-se de 14 trabalhos disponíveis eletronicamente na base de dados do Sistema de Bibliotecas da UFMG. Para realizar a discussão, agrupou-se os trabalhos em categorias, conforme quadro a seguir:

QUADRO 1

Categorias dos trabalhos por tema

\begin{tabular}{|c|c|}
\hline TEMAS & AUTORES \\
\hline $\begin{array}{l}\text { 1. Metodologias de ensino para pessoa com deficiência } \\
\text { com uso ou não de Tecnologia }\end{array}$ & $\begin{array}{l}\text { Santiago (2016); Loureiro (2006); Souza (2015); } \\
\text { Abreu (2010); Rodrigues (2013); Lima (2014); Lima } \\
\text { (2012); }\end{array}$ \\
\hline $\begin{array}{l}\text { 2. Inclusão Social da pessoa com deficiência no Ensino } \\
\text { Superior/Trabalho }\end{array}$ & Nogueira (2016); Silva (2011); Reis (2010); \\
\hline 3. Implementação da Lei de Cotas & $\begin{array}{l}\text { Santos (2018); Ribeiro (2018); Dias (2014); Figueiredo } \\
\text { (2015) }\end{array}$ \\
\hline
\end{tabular}

Fonte: Elaborado pelos autores

Considerando a distribuição por categoria dos trabalhos localizados, tem-se a discussão dos temas.

\section{DISCUSSÃo}

\subsection{METOdologias DE ENSINO PARA A PESSOA COM DEFICIÊNCIA COM USO OU NÃO DE TECNOLOGIA}

Para a discussão desta categoria não foi realizada triagem de trabalhos, considerando que metodologias de ensino podem ser amplamente disseminadas ou replicadas como estratégias de acessibilidade em todos os níveis da educação.

O trabalho realizado por Souza (2015) teve enfoque na Educação à Distância (EaD) como ferramenta de estudo e integração para as pessoas surdas. A pesquisa identificou e propôs soluções para as inconsistências de acessibilidade na plataforma EaD da UFMG para usuários surdos. Souza (2015) finaliza o seu trabalho trazendo reflexões para o processo de inclusão de pessoas com deficiência no ensino superior acerca de metodologias de ensino bem como da capacitação das pessoas que atuam nas relações do dia-a-dia para a promoção de uma interação com respeito.

A pesquisa de Lima (2014) visou o desenvolvimento e apresentação de procedimentos metodológicos para elaborar um glossário ilustrado, bimodal, contemplando a Língua Portuguesa e a Língua de Sinais para Curso de Educação Profissional. Ao discorrer sobre o assunto, considerou a escassez de termos dessa especificação na Libras. 0 "Manual de Ensino de Desenho Arquitetônico acompanhado do dicionário terminológico" elaborado na pesquisa, com a possibilidade de traduzir "termos técnicos para a Libras" foi incluído on line no site http://www.glossario.libras.ufsc.br/ da Universidade Federal de Santa Catarina (LIMA, 2014, p. 257).

A investigação de material didático e recursos de tecnologia assistiva que auxiliam alunos com deficiência visual para cursarem disciplinas presenciais e semi-presenciais em um curso superior foi proposta por Santiago (2016), na intenção de compreender o processo e suas limitações.

Santiago (2016) apresentou a proposta de criação de um "Guia de acessibilidade na Produção de Materiais Didáticos às pessoas com Deficiência Visual" na perspectiva de contribuir para a inclusão de alunos com deficiência visual no ensino superior, além de auxiliar professores e técnicos na produção do material.

O uso das Tecnologias da Informação e Comunicação (TICs) foi abordado por Abreu (2010) como principal suporte para o apoio da alfabetização com Libras. A autora apresentou um conjunto de recomendações que podem ser verificadas em um momento anterior ao desenvolvimento de projetos que utilizam TICs como apoio ao processo de aprendizagem de crianças surdas.

Abreu (2010) observou lacunas nos ambientes educacionais virtuais pela falta de compreensão dos desenvolvedores de que a interação visual não garante completa comunicabilidade, pois a primeira língua da maioria das pessoas surdas é a Libras e não o Português. 
Utilizar-se da Musicoterapia como recurso metodológico foi tema discutido por Loureiro (2006). A pesquisa abordou a musicoterapia como uma ciência que interfere no comportamento e desenvolvimento humano ao ser utilizada como estratégia para desenvolver habilidades de pessoas com deficiência.

O trabalho da autora deduziu proposições metodológicas de exercícios no ensino da educação musical e descreveu casos desse processo na educação musical especial. Concluiu que a inclusão da criança com deficiência é bem mais abrangente do que simplesmente a inclusão física desta nos ambientes educacionais.

Rodrigues (2013) discutiu limites e possibilidades para construção de práticas pedagógicas inclusivas para alunos com deficiência e transtornos globais no desenvolvimento em uma escola municipal. 0 foco principal da pesquisa versou sobre as mudanças necessárias que deveriam ser realizadas na Escola para atendimento das especificidades dos alunos com deficiência e transtornos globais de desenvolvimento, sendo uma das principais, a parceria entre professores da escola regular e professores especializados do "Atendimento Educacional Especializado" (RODRIGUES, 2013, p. 227).

O objetivo do trabalho realizado por Lima (2012, p.16) foi pesquisar "as concepções de inclusão social e educacional presentes nas políticas públicas nacionais para a formação inicial dos professores, implementadas a partir de 1988 até o ano de 2010, com recorte nas direcionadas para a pessoa com deficiência". Considerou em sua análise que a inclusão da pessoa com deficiência no ambiente escolar ainda é prerrogativa arraigada de dilemas e desafios, principalmente no que diz respeito à formação docente.

A autora concluiu que as Instituições de Ensino Superior ainda trabalham com currículos tradicionais e inadequados e esse processo de formação de professores em nada contribui para atenderem as necessidades de escolas inclusivas.

\subsection{INCLUSÃO SOCIAL DA PESSOA COM DEFICIÊNCIA NO ENSINO SUPERIOR / TRABALHO}

A proposta de estudo de Nogueira (2016) foi descrever o perfil dos servidores com deficiência (ScD) da UFMG, analisando o processo de lotação e acompanhamento destes. A autora verificou que o número de ScD na UFMG ainda não atinge a percentagem determinada na legislação, mas notou aumento de ingresso no quadro de pessoal da Instituição. Quanto ao perfil dos ScD concluiu que nenhum dos ingressantes nas cotas de deficientes ocupa o cargo de docente e o gênero feminino encontrou-se em minoria num contexto geral.

A pesquisa de Nogueira (2016) foi delimitada aos servidores Técnico-administrativos em Educação (TAE's) e resultou no perfil: maioria do sexo feminino, ao contrário do que ocorre com a população total de ScD da UFMG; faixa etária de ingresso entre 26 e 35 anos; 95,3\% tiveram trabalhos formais anteriores, fazendo-a concluir que outras experiências contribuem para inclusão; o cargo de todos os pesquisados foi o de assistente em administração, pois se trata da categoria com maior número de vagas e, consequentemente, de cotas de vagas para deficientes. Constatou, ainda, que a maioria dos ScD-TAE's possuem formação acadêmica superior ao exigido pelo cargo. Essa informação vai contra o que acontece no Brasil, mas pode ser justificada pelo incentivo oferecido pela Instituição com oferta de bolsas e Plano de Carreira.

Nogueira (2016) relatou que, para a devida lotação e acompanhamento do ScD na UFMG, a Diretoria de Recursos Humanos da UFMG, juntamente com o Núcleo de Acessibilidade e Inclusão (NAI), realizam estudo do posto de trabalho, contando com o auxílio de assistentes sociais, psicólogos e terapeutas ocupacionais. 0 estudo levantou que $74 \%$ dos ScD permanecem no mesmo setor onde foram investidos o que demonstra que é satisfatória a inclusão na UFMG.

Reis (2010) buscou investigar e analisar o processo de implementação das políticas de inclusão por parte das universidades federais mineiras (UFM), identificar os limites, possibilidades e impasses por elas enfrentados no desenvolvimento de ações com o propósito de assegurar o acesso e a permanência dos alunos com necessidades educacionais especiais (NEE). Além de discutir a condição de equiparação de oportunidades oferecida ao estudante com NEE associadas a alguma deficiência no ensino superior.

O autor pontuou que para tornar viável a operacionalização da educação inclusiva na prática pedagógica no ensino superior é fundamental que as políticas públicas da educação inclusiva sejam conhecidas e transformadas em políticas institucionais. A pesquisa de Reis (2010) demonstrou que 100\% das universidades disponibilizam quase todas as condições de acessibilidade no vestibular, porém apenas $55 \%$ oferecem os recursos de acessibilidade durante a permanência no curso. 
O objetivo da pesquisa de Silva (2011) foi compreender as razões da oferta diferenciada de cursos para as pessoas com deficiência, especialmente no que diz respeito à formação para o trabalho. Nesse sentido, buscou identificar e examinar as causas que geram desigualdade educacional em relação à pessoa com deficiência na organização escolar.

Silva (2011, p.181) justificou esse aspecto, considerando as barreiras de ingresso dos alunos com deficiência nos cursos de educação profissional, onde a percepção da pessoa com deficiência como "incapaz" gera destaque em relação às dificuldades decorrentes da deficiência nos indivíduos e ignora outros aspectos como, por exemplo, as suas circunstâncias econômicas, políticas e culturais. Concluiu que a formação fundamental e média provenientes da educação profissional deve articular projeto pedagógico com estratégias de acessibilidade, promovendo assim uma universalidade para atendimento dos alunos ao prepará-los para a atuação no mercado de trabalho.

\subsection{IMPLEMENTAÇÃO DA LEI DE COTAS}

Ao dissertar sobre a implementação da Lei de Cotas em três universidades mineiras, Santos (2018) discorre sobre o processo histórico das políticas públicas afirmativas no cenário nacional e internacional. A metodologia utilizada por Santos (2018) possibilitou acesso a variadas fontes de informações como docentes, gestores, alunos, de forma a contribuir para o entendimento do processo de implementação da Lei de Cotas nessas IFES. Sobre a implementação da Lei, o autor concluiu que esta política pública está coerente com o Plano Nacional de Educação (PNE), meta 12, ao propor elevar taxa de matrícula da população de 18 a 24 anos no ensino superior.

Em relação à operacionalidade nas instituições pesquisadas, Santos $(2018$, p. 172) pondera que "a implementação dessa política pública trouxe implicações importantes e vem exigindo das universidades a adoção de um conjunto de procedimentos específicos, alguns dos quais estranhos à sua prática de até então".

Santos (2018) concluiu que a Lei de Cotas inseriu novidades que passaram a influenciar a gestão universitária e pondera que isso não deve se tornar obstáculo para efetivar o seu objetivo principal que é incluir segmentos que sofreram discriminações por fenômeno histórico vivenciado no Brasil.

Em consonância a essa perspectiva de trabalho, Dias (2014) realizou o seu estudo propondo fornecer subsídios para a tomada de decisão em um instituto federal, considerando o ingresso de alunos pela política de cotas. Os resultados apontaram que: no período de novembro de 2012 a janeiro de 2014, cerca de $20 \%$ do total de vagas da instituição foram transferidas para ampla concorrência por não terem sido ocupadas pelos cotistas; houve indícios de candidatos sem ter o direito, concorrerem às vagas como cotistas; não houve estratificação socioeconômica considerável em relação aos estudantes cotistas e estudantes da ampla concorrência.

A escolha do curso de Medicina no contexto da implementação de políticas como a Lei de Cotas e o Sistema de Seleção Unificada (SISU) foi tema pesquisado por Ribeiro (2018). 0 autor observou que os cotistas com restrição de renda advinham de condições socioeconômicas que se aproximavam do teto exigido pela Lei, ou seja, a escolha do curso de Medicina ocorreu para estudantes com a renda familiar mais elevada, considerando as modalidades delimitadas na legislação de cotas. Dentre as principais conclusões, destacou-se a escolha da Universidade pela qualidade de ensino e proximidade aos familiares.

Figueiredo (2015) propõe compreender a trajetória de alunos de um curso superior de uma Instituição no contexto da expansão universitária. Apontou que "uma das razões que dificultam o processo de afiliação ao ensino superior está relacionado, além da origem familiar desses estudantes, com a trajetória escolar na educação básica" (FIGUEIREDO, 2015, p.163). Todas as constatações da pesquisa ocorreram de adventos externos, pois conclui que na universidade pesquisada a expansão universitária propiciou o aumento de vagas, mas os processos de integração e afiliação dos estudantes não ocorreram de forma inclusiva.

\section{CONSIDERAÇÕES FINAIS}

O caminho a ser trilhado pelas discussões sobre inclusão e acessibilidade no Ensino Superior ainda é longo. Notou-se que a percepção de parte dos autores é a de que a Educação Inclusiva pode encontrar reações negativas para a sua implementação, mas se trata de um movimento necessário para o avanço da sociedade brasileira. 
Os trabalhos sobre metodologias de ensino para alunos com deficiência foram realizados na tentativa de contribuírem para a inclusão e permanência desses alunos em todos os níveis de ensino. Sobre esse aspecto, as pesquisas localizadas na Base de Dados do Sistema de Bibliotecas da UFMG podem auxiliar no desenvolvimento de estratégias metodológicas institucionais para atender a crescente inserção de estudantes cotistas com deficiência.

Considerou-se que os estudos sobre a Lei de Cotas ainda se encontram em fase embrionária, pois a legislação é recente e os caminhos que garantirão a sua implementação ainda estão sendo percorridos pelas IFES. Por outro lado, trata-se de um processo que pode ser postergado ou até mesmo minado pela falta de estratégias internas de promoção ou de acompanhamento do dispositivo legal na estrutura institucional.

Por fim, concluiu-se que os esforços para a implementação da Lei de Cotas e a garantia de acessibilidade aos estudantes com deficiência devem ser realizados a partir de reflexões acerca da historicidade vivenciada por esse público no cenário brasileiro.

\section{REFERÊNCIAS}

[1] Abreu, P. M. Recomendações para projetos de TICs para apoio a alfabetização com libras. Dissertação (Mestrado) - Instituto de Ciências Exatas, Universidade Federal de Minas Gerais, Belo Horizonte, 2010.

[2] Brasil. Lei no 12.711, de 29 de agosto de 2012. Dispõe sobre o ingresso nas universidades federais e nas instituições federais de ensino técnico de nível médio e dá outras providências. Disponível em: < http://www.planalto.gov.br/ccivil_03/_ato2011-2014/2012/lei/l12711.htm>. Acesso em: 14 maio 2018.

[3] Brasil. Lei no 13.409, de 28 de dezembro de 2016. Altera a Lei no 12.711, de 29 de agosto de 2012, para dispor sobre a reserva de vagas para pessoas com deficiência nos cursos técnico de nível médio e superior das instituições federais de ensino. Disponível em: <http://www.planalto.gov.br/ccivil_03/_ato20152018/2016/lei/L13409.htm>. Acesso em: 14 maio 2018.

[4] Brasil. Ministério da Educação. Marcos político-legais da educação especial na perspectiva da educação inclusiva. Brasília: Ministério da Educação, 2010. Disponível em:<http://portal.mec.gov.br/busca-geral/194secretarias-112877938/secad-educacao-continuada-223369541/17009-educacao-especial> Acesso em: 25 jul. 2018.

[5] Brasil. Ministério da Educação. Politica e resultados 1995-2002: educação especial. Brasília: Portal Domínio Público, 2002.

[6] Dias, M. T. Lei de Cotas: um estudo da reserva de vagas em uma instituição federal de ensino através da descoberta de conhecimento em bases de dados. Dissertação (Mestrado) - Escola de Ciência da Informação, Universidade Federal de Minas Gerais, Belo Horizonte, 2014.

[7] Ferreira, N. S. de A. As pesquisas denominadas "Estado da Arte". Educação \& Sociedade, Campinas, ano XXIII, no 79, p. 257-272, 2002.

[8] Figueiredo, A. C. Processos de integração e afiliação à vida acadêmica de estudantes de camadas populares no contexto da expansão universitária. Tese (Doutorado) - Faculdade de Educação, Universidade Federal de Minas Ferais, Belo Horizonte, 2015.

[9] Lima, L. F. Inclusão sócio-educacional e diversidade: debate conceitual e desenvolvimento histórico-legal no Brasil após 1988. Tese (Doutorado) - Faculdade de Educação, Universidade Federal de Minas Gerais, Belo Horizonte, 2012

[10] Lima, V. L. S. Língua de sinais proposta terminológica para a área de desenho arquitetônico. Tese (Doutorado) - Faculdade de Letras, Universidade Federal de Minas Gerais, Belo Horizonte, 2014.

[11] Loureiro, C. M. V. Musicoterapia na educação musical especial de portadores de atraso do desenvolvimento leve e moderado na rede regular de ensino. Dissertação (Mestrado) - Escola de Música, Universidade Federal de Minas Gerais, Belo Horizonte, 2006.

[12] Magalhães, J. C.; Severino, M. R. Uma análise da institucionalização da política de cotas nas universidades federais brasileiras. In: Congresso Nacional de Educação - Conedu, 11, 2017, João Pessoa, PB. Anais...(on-line). Paraíba: CONEDU, $2017 . \quad$ Disponível em: <http://editorarealize.com.br/revistas/conedu/trabalhos/Trabalho_EV073_MD1_SA6_ID6693_11092017181311.pdf $>$ Acesso em: 19 jul. 2018.

[13] Nogueira, P. M. Inclusão da pessoa com deficiência no trabalho: possibilidades institucionais no Serviço Público Federal. Dissertação (Mestrado) - Faculdade de Medicina, Universidade Federal de Minas Gerais, Belo Horizonte, 2016. 
[14] Petten, A. M. N. V. et al. Cotas para pessoas com deficiência nas instituições federais de ensino: desafios e perspectivas para a acessibilidade e inclusão na Ufmg. In: III Congresso de Inovação e Metodologias no Ensino Superior - CIM, 11, 2017, Belo Horizonte, MG. Anais...(on-line). Belo Horizonte: CIM, 2017. Disponível em:< https://congressos.ufmg.br/index.php/congressogiz/CIM/paper/view/593/292> Acesso em: 23 jul. 2018.

[15] Pletsch, M. D.; Leite, L. P. Analise da produção cientifica sobre inclusão no ensino superior brasileiro. Educar em Revista, Curitiba, v. 33, p. 87-106, 2017.

[16] Reis, N. M. M. Política de inclusão escolar de pessoas com necessidades educacionais especiais no ensino superior e as universidades federais mineiras. Dissertação (Mestrado) - Faculdade de Educação, Universidade Federal de Minas Gerais, Belo Horizonte, 2010.

[17] Ribeiro, G. M. A escolha do curso de Medicina no contexto de implementação de políticas de democratização do acesso ao Ensino Superior. Tese (Doutorado) - Faculdade de Educação, Universidade Federal de Minas Gerais, Belo Horizonte, 2018.

[18] Rodrigues, S. M. A construção de práticas pedagógicas inclusivas em uma escola pública de Belo Horizonte. Tese (Doutorado) - Faculdade de Educação, Universidade Federal de Minas Gerais, Belo Horizonte, 2013.

[19] Santiago, J. V. B. Possibilidades e limitações nas práticas pedagógicas no ensino superior: uma análise do material didático e dos recursos de tecnologia assistiva acessíveis às pessoas com deficiência visual. Dissertação (Mestrado) - Faculdade de Educação, Universidade Federal de Minas Gerais, Belo Horizonte, 2016.

[20] Santos, A. P. Implementação da lei de cotas em três universidades federais mineiras. Tese (Doutorado) Faculdade de Educação, Universidade Federal de Minas Gerais, Belo Horizonte, 2018.

[21] Silva, I. M. A. Políticas de educação profissional para pessoas com deficiência. Tese (Doutorado) - Faculdade de Educação, Universidade Federal de Minas Gerais, Belo Horizonte, 2011.

[22] Souza, L. C. Recomendações para cursos on-line em língua portuguesa com foco na integração de alunos surdos. Tese (Doutorado) - Faculdade de Letras, Universidade Federal de Minas Gerais, Belo Horizonte, 2015. 


\section{Capítulo 4}

\section{As significações de educação especial e inclusiva em diferentes períodos da história da educação.}

\section{Marcia Raika e Silva Lima}

Resumo: 0 estudo que apresentamos discute os Significados e os Sentidos da educação inclusiva, para alunos com necessidade educativas especiais-NEEs em processo de escolarização em escolas regulares, constituídos pela sociedade nos períodos históricos. As discussões que surgem sobre a inclusão, emergem a compreensão de exclusão, pois se se almeja a inclusão social e educacional de alguém é porque este estava/está excluído. Nesse sentido, trazer á tona a categoria exclusão, é necessário compreender como Sawaia $(2012$, p. 8) ao anunciar que esta "apresenta contraditoriedade na sua constituição: a qualidade de conter em si a sua negação e não existir sem ela, isto é, ser idêntico à inclusão (inserção social perversa)". Trata-se de pesquisa qualitativa, de caráter bibliográfica, resultado de trabalho final de disciplina do curso de Doutorado em Educação da Universidade Federal do Piauí, no ano de 2014. Teve como o objetivo geral investigar os sentidos e os significados de educação inclusiva constituídos nos diferentes períodos históricos. E, como objetivos específicos: Compreender sobre significados e sentidos como categoria que possibilitam explicar o fenômeno estudado; Especificar as mudanças nos significados e nos sentidos da educação inclusiva; Analisar o par dialético inclusão e exclusão como essências para a compreensão da formação de significados e de sentidos de educação inclusiva. As considerações teóricas e metodológicas articulam-se com o Materialismo Histórico e Dialético e a Psicologia Sócio-Histórica. Como análise das discussões teóricas ora apresentadas, apreendemos que não obstante ao progresso alcançado pela sociedade civil e educacional no que tange a adesão e a conscientização dos benefícios que a inclusão pode proporcionar para os alunos com necessidades educativas especiais, a inclusão encontra significados e sentidos de resistências por parte de professores, nos dias atuais.

Palavras-chave: Significado e sentido. Educação inclusiva. Exclusão. 


\section{INTRODUÇÃO}

As discussões sobre os significados e os sentidos da educação inclusiva constituídos nos períodos históricos da educação apresentam-se como relevante para a atualidade, possibilitando o conhecimento da evolução do pensamento e da linguagem. Nesse sentido, apresentamos o estudo teórico acerca da constituição dos significados e dos sentidos da educação inclusiva de alunos com necessidades educativas especiais ${ }^{12}$-NEEs, no âmbito dos diferentes períodos históricos da humanidade.

Períodos que ora apresentam-se como passíveis de exclusão dos alunos com NEEs pelo ideário constituído socialmente de aluno ideal, e que ora apresentam-se como capazes de inclusão destes alunos no sistema regular de ensino, como prerrogativa legal e de busca de uma sociedade mais justa e como menos desigualdades sociais. Mediante o aumento das matrículas dos alunos com NEEs na escola regular comum (CHAVES, 2013), é necessário reforçar que a escola deve preparar-se para receber estes alunos. É na escola regular que se deve ensinar o direito à cidadania e os conhecimentos elaborados culturalmente. A educação inclusiva surge com a finalidade de que os alunos com NEEs possam usufruir desse direito.

Diante da necessidade de aprofundar conhecimentos que desvelem sobre o objeto em estudo, isto é, sobre os significados e os sentidos da educação inclusiva, foi dado ênfase à categoria significado e sentido. Mas, é possível evidenciar as demais categorias entrelaçadas nas discussões apresentadas. Diante do exposto, considerando o objeto de estudo que aqui se delineia, apresentamos o seguinte problema de pesquisa: Como os significados e os sentidos de educação inclusiva, foram se constituindo em períodos históricos da educação, da antiguidade aos dias atuais?

Na busca por reflexões acerca da problemática apresentada, temos como objetivo deste estudo, investigar os significados e os sentidos de educação inclusiva constituídos nos diferentes períodos históricos. As discussões sobre significado e sentido foram introduzidas por Vygotski $(2004,2008,2009)$ e seus colaboradores, Luria e Leontiev (1978), tendo por base filosófica, o materialismo histórico-dialético, de Marx $(1987,2002)$.

Amparamo-nos teoricamente, para desvelar os significados e os sentidos investigados,na compreensão de Vygotski (2008, p. 150), ao afirmar que "o significado de uma palavra representa um amálgama tão estreito do pensamento e da linguagem, que fica difícil dizer quando se trata de um fenômeno da fala ou de um fenômeno do pensamento".

Compreendemos, diante do exposto, a relevância do significado para a constituição do ser social.

Leontiev (1978) ao fazer inferência ao significado e sentido, infere que os significados são constituídos pela sociedade, que apresentam sua própria história no desenvolvimento da linguagem e no desenvolvimento da consciência social. É na construção dos significados que se evidencia o movimento histórico da humanidade e de seus recursos cognoscitivos, bem como das noções ideológicas da sociedade.

Diante do que foi apreendido sobre o significado como constructo social, ressaltamos que os sentidos indicam a construção subjetiva de cada pessoa, que ao apropriar-se do significado de determinado objeto social, elabora seu próprio conceito acerca do objeto apropriado. Dessa forma, para Zuin (2011, p. 30):

Uma mesma palavra possui um significado, formado objetivamente ao longo da história e que, em forma potencial, conserva-se para todas as pessoas, refletindo as coisas com diferente profundidade e amplitude. Porém, junto com o significado, cada palavra tem um sentido que condiz ao contexto e às vivências afetivas do sujeito. Portanto, o sentido é o elemento fundamental da utilização viva da palavra,ligada a uma situação concreta afetiva, por parte do sujeito.

Como salienta Zuin, é na existência dos significados que se constroem as leis históricas sociais, que possibilitam a formação cultural da sociedade. Por meio das relações sociais que os significados se individualizam e se subjetivam, não perdendo assim, a objetividade. E que, é o sentido "que cria a parcialidade da consciência humana" (LEONTIEV, 1978, p. 20). Criando as diferentes interpretações dadas ao objeto social.

12 Conforme Carneiro (2010), a tipificação alunos com necessidades educativas especiais-NEEs é ampla, assim nos limitamos àqueles com deficiências, transtornos globais do desenvolvimento e altas habilidades/Superdotação. (BRASIL, 2008). 
Na apropriação de conhecimentos, sobre os significados e os sentidos da educação inclusiva, é possível vislumbrar o movimento dialético que mostra a dicotomia exclusão e inclusão vivenciada pelos alunos com necessidades educativas especiais-NEEs. Como infere Kosik (2002, p. 20) o movimento dialético deve ser realizado nas diferentes relações sociais, para que haja conhecimento do objeto na sua essência:

A dialética é o pensamento crítico que se propõe a compreender a 'coisa em si' e sistematicamente se pergunta como é possível chegar à compreensão da realidade.

Por isso, é o oposto da sistematização doutrinária ou da romantização das representações comuns. 0 pensamento que quer conhecer adequadamente a realidade, que não se contenta com os esquemas abstratos da própria realidade, nem com suas simples e também abstratas representações, tem de destruir a aparente independência do mundo dos contatos imediatos de cada dia. [...]; por trás do movimento visível, o movimento real interno, por trás do fenômeno, a essência.

Para Kosik (2002), compreender o objeto estudado requer ultrapassar o pensamento doutrinário, as crenças e as idealizações sobre o objeto e imergir no pensamento dialético, conhecendo-o na sua totalidade, na realidade concreta e objetiva em que está envolvido.

Pensamento este que critica, desvenda o real, torna-o visível e possibilita o conhecimento do objeto em si, na sua essência.

As discussões que surgem sobre inclusão, emergem a compreensão de exclusão, pois se se almeja a inclusão social e educacional de alguém é porque este estava/está excluído.

Nesse sentido, trazer á tona a categoria exclusão, é necessário compreender como Sawaia (2012, p. 8) ao anunciar que esta "apresenta contraditoriedade na sua constituição: a qualidade de conter em si a sua negação e não existir sem ela, isto é, ser idêntico à inclusão (inserção social perversa)".

É necessário compreender os dois conceitos, que são antagônicos, mas ao mesmo tempo apresentam conexões, se temos interesse em anular um e deixar sobressair o outro. No estudo apresentado, privilegiamos a inclusão, considerando esta como essencial para uma sociedade mais justa, igualitária e sem preconceitos com ${ }^{13}$ a diversidade humana e cultural que existe na sociedade. E que, surgiu com a finalidade de superação da exclusão, pela qual as pessoas com NEEs foram submetidos por longos períodos da história da educação.

Exclusão e inclusão: movimento dialético na compreensão da educação inclusiva Na evolução da trajetória da história das pessoas com necessidades educativas especiais é possível acompanhar o processo de exclusão social e educacional pelo qual foram acometidos por séculos. Mas que, nos dias atuais estão conseguindo superá-lo, diante da proposta da inclusão social e escolar, que fora defendida pelos movimentos sociais. Com os movimentos sociais que buscam ideais de igualdades sociais, as pessoas com NEEs estão conquistando novos espaços, novas realidades sociais e educacionais, ainda que encontrem grupos sociais que são não são favoráveis à inclusão.

Vários foram os preconceitos construídos e acumulados ao longo da trajetória de exclusão pela qual os alunos com NEEs foram submetidos, e que ainda se constituem como barreiras e limitações para o desenvolvimento de uma política de inclusão social e educacional para os dias atuais. Sawaia (2012, p. 9), expressa que:

A dialética inclusão/exclusão gesta subjetividades específicas que vão desde o sentir-se discriminado ou revoltado. Essas subjetividades não podem ser explicada unicamente pela determinação econômica, elas determinam e são determinadas por formas diferenciadas de legitimação social e individual, e manifestam-se no cotidiano como identidade, sociabilidade, afetividade, consciência e inconsciência.

\footnotetext{
${ }^{13}$ Compreendemos preconceito como Jodelet (2012, p. 61), ao considerá-lo como um julgamento positivo ou negativo, formulado sem exame prévio a propósito de uma pessoa ou de uma coisa e que, assim, compreende vieses e esferas específicas.
} 
Ancorando ao que expressa Sawaia, os avanços sociais e educacionais alcançados pela inclusão social e educacional para as pessoas com necessidades educativas especiais, encontram-se permeadas por subjetividades de preconceitos e exclusão, que não se diluem no tempo. Subjetividades alicerçadas nas relações sociais, que evidenciam a exclusão ou a inclusão destas pessoas ao longo dos tempos.

Para Fogli (2010), a palavra inclusão tem origem do latim includere, e significa encerrar, colocar dentro, confinar ou bloquear. Enquanto verbo, incluir significa várias acepções, todas elas com o sentido de algo ou de alguém inserido em conjuntos de coisas ou pessoas. (AURÉLIO, 2010). 0 conceito de inclusão defendido neste estudo se refere à atividade social, consciente e transformadora com fins a incluir alunos com necessidades educativas especiais na escola regular. Considerando os aspectos sociais, culturais, cognitivos e afetivos para o processo de escolarização, com qualidade, destes alunos.

A inclusão de alunos com NEEs na escola regular, mediada pela educação inclusiva, rompe com a escola tradicional, que concebe as crianças com necessidades educativas especiais sem possibilidades de terem respostas eficazes às suas limitações e especificidades.

Contradizendo essa perspectiva tradicional, a educação inclusiva caracterizando-se, como assevera Magalhães (2011, p. 102), por ser uma escola em que:

0 processo de aprendizagem de qualquer criança apresente ou não deficiência, resulta da consideração de três aspectos: a) A superação da visão das deficiências como apresentando apenas aspectos limitadores ao desenvolvimento e à aprendizagem; b) A clareza do papel do professor como 'outro' que intermedia o contato da criança com os conceitos científicos e, c) A colaboração da educação especial com área que pode por em foco aprendizagens significativas para alunos com deficiência.

A escola inclusiva, para os alunos com NEEs apresenta-se como uma evolução no campo da educação para estes alunos. Uma escola que se propõe a romper como as desigualdades sociais, que buscar compreender as singulares de cada um destes alunos, potencializando as suas capacidades para a aprendizagem e o desenvolvimento. Com possibilidades de revolucionar a educação escolar, a educação inclusiva, beneficia não só os alunos com NEEs, com todos que fazem parte do processo de escolarização e que estavam/estão à margem deste processo.

Com esta compreensão de educação inclusiva, enlaçamos à compreensão de Vygotski (2004, 2009), por compreender que seus estudos valorizam os aspectos culturais das relações humanas. Estes aspectos ao serem apreendidos no processo educacional influenciam nas ações humanas que, de certa forma, orientem e intervêm nos processos de aprendizagem e de desenvolvimento das pessoas que a apropriam.

Apropriação que deve ser direcionada para a realização de atividades educativas que propiciem condições para que todos os envolvidos neste processo educativo consigam apreender o conhecimento que se está conhecendo e que já existem socialmente. Para assim,construir novos significados e novos sentidos que possibilitem reflexão crítica sobre os significados já existentes, mas que não propiciam o desenvolvimento pessoal e social da época vigente.

Favorecendo com esta compreensão, a construção de novos significados e novos sentidos que visem à transformação de cada pessoa, na sua individualidade, do outro, enquanto ser social e da sociedade, construída historicamente. Como salienta Duarte (2013, p.17):

Por um lado, tanto no pensamento quanto na ação, não se cria o novo sem a apropriação do já existente. Não se podem criar novas ideais do nada, é preciso trabalhar a partir das ideias existentes. Isso não é negativo, ao contrário, é uma característica humana muito importante (poder partir das gerações passadas).

É necessário compreender e interpretar a realidade cultural apropriada, para que se possa refletir criticamente sobre ela. Diante do que já foi construído historicamente, não tomá-lo como uma cultura pronta e acaba, mas como passível de constituição de novas significações, a partir do existente, com o fim de contribuir para a formação de novas culturas, que tenham relação com a época vigente.

Nessa discussão de constituição da sociedade vigente relacionando ao processo histórico existente, analisamos a evolução dos significados e dos sentidos da educação inclusiva, para alunos com NEEs. Estes alunos por vários períodos históricos foram submetidos a processo de exclusão, marginalização e de nulidade social e educacional (LIMA, 2010; LIMA, 2006; JANNUZZI, 2006; MAZZOTA, 2005). 
Analisando, brevemente, a evolução dos significados e dos sentidos da educação inclusiva constituídos nos períodos históricos da educação, trazemos as discussões de Mazzota (2005) e Glat (2009). 0 primeiro autor, para a apresentação dos significados e dos sentidos constituídos acerca da educação especial, que nas análises apresentadas não se evidencia relação com educação inclusiva. Esta compreensão preponderou até o início do século XIX. E, a segunda, a autora Glat (2010), com significados e sentidos da educação inclusiva após século XIX.

Resgatando a história da educação especial apresentada nos estudos de Mazzotta (2005) diante do cenário da história da educação de pessoas com deficiência, é sinalizado pelo autor que:

$\mathrm{Na}$ antiguidade clássica pautada pelo ideal de perfeição, as pessoas com deficiências eram eliminadas, como acontece hoje em algumas sociedades indígenas, por motivos religiosos ou crenças comuns. Na Idade Média, acreditava-se que muitas pessoas eram portadoras de doenças contagiosas ou estavam possuídas pelo demônio; em seguida, com o início da produção mercantil, elas foram consideradas incapazes e, posteriormente, deficientes. Durante o Nazismo, a eliminação das pessoas com deficiência recomeçou, não mais associada a culturas específicas, e sim baseada numa motivação aparentemente irracional, guiada pelo princípio da eugenia, ou seja, de purificação.

Conforme anunciado por Mazzota, as significações de educação para as pessoas com deficiências, consistiram em momentos de exclusão total do campo educacional, pelos mais diversos motivos. Dentre aqueles que eram evidenciados diante dos aspectos físicos, cognitivos e comportamentais destas pessoas, àqueles oriundos de cultos que purificavam a alma, sendo a deficiência considerada impura, na qual estas eram eliminadas do convívio social.

Avançando no contexto histórico, Glat (2009) descreve que a partir dos anos de 1990, houve reconhecimento da educação inclusiva nos diferentes países, dentre eles o Brasil. Para a autora (2009, p. 16):

A educação inclusiva significa um novo modelo de escola em que é possível o acesso e a permanência de todos os alunos, e onde os mecanismos de seleção e discriminação, até então utilizados, são substituídos por procedimentos de identificação e remoção de barreiras para a aprendizagem.

Nos significados e nos sentidos de educação inclusiva evidenciados pela autora Glat é possível identificar mudanças de significações sobre a educação para alunos com NEEs. Para estes alunos, a educação inclusiva não os exclui da escola regular, mas, dar-lhe condições de acesso e de permanência, com possibilidades de aprendizagem da cultura formal.

Estamos diante de significações sociais de educação inclusiva. Uma evidenciada por Glat (2009), como necessária para incluir os alunos com NEEs no processo de escolarização.

Mas, que é a polemizada nos dias atuais, diante das condições reais pela qual foi imposta no cenário educacional. Sem que haja escolas adequadas com recursos humanos e materiais, para a atividade educativa com estes alunos. E a outra de Mazzota (2005), em que há evidência de exclusão dos alunos com necessidades educativas especiais da educação formal.

Com os significados e os sentidos da educação de alunos com NEEs constituídos na análise realizada por Mazzota, trazemos à reflexão: por que permanecer com estas significações sociais, se consideramos que as pessoas são seres sociais, que aprendem, transformam e se desenvolvem no convívio com as outras pessoas e com a apropriação da cultura construída socialmente? Não estaríamos em contradição com o movimento dialético, sobretudo da lei da negação da negação, isto é, em que se desvela o objeto real/atual partindo do conhecimento já existente, e a partir deste busca-se possibilidades para a construção de novos, mas, sem desconsiderar o antigo. Como resposta para estas reflexões, recorremos à compreensão de Kopnin (1978, p. 65), ao discorrer sobre o surgimento da nova filosofia do materialismo dialético, enquanto conhecimento positivo e substancial do mundo, e do fim da filosofia que se opõe à ciência, aferindo que "essa concepção de mundo não só mantém seu significado como ganha horizontes para o seu desenvolvimento". Para assim, compreendermos que a substituição de uma realidade social, não ocorre abruptamente, ou mesmo anula na sua totalidade a realidade que a precedeu. 0 significado social permanece, mas havendo necessidade de transformação. 
Para sustentar essa afirmação recordamos os estudos de Vygotski (2009) sobre a teoria do pensamento e da palavra ${ }^{14}$, na qual identificou o significado como unidade do pensamento e da linguagem. 0 autor russo (2009, p. 398), defendeu a tese de que "a descoberta da mudança dos significados das palavras e do seu desenvolvimento é a nossa descoberta principal [...]".

Descoberta que possibilita compreendermos como é possível identificar certos objetos sociais no seu processo de transformação. Apoiando-nos nesta tese é possível compreender que os significados sociais apreendidos culturalmente ao longo da história da humanidade, não permanece imutável, mas contribui para a evolução social. Para Duarte (2013, p. 18), “a realidade não se apresenta ao pensamento de forma imediata”. Para que possamos interpretá-la e compreendê-la é necessário o afastamento desta realidade, conhecê-la além das aparências, para em seguida retomá-la, e assim construir significados e sentidos.

A Psicologia Sócio-Histórica, como as categorias significados e sentidos, se propõe identificar os objetos, fugindo do aparente, do imediatismo, do apenas verbalizado, e, se propondo conhecê-los na sua essência, na sua gênese. 0 estudo da educação inclusiva necessita desta compreensão, para que seja interpretada, na evolução da sociedade, com a análise da lógica dialética.

Para Kosik (2002) o movimento dialético deve ser realizado nas diferentes relações sociais, para que haja conhecimento do objeto na sua essência. Entrelaçamos à compreensão de Kosik para inferir que as significações sociais sobre a educação inclusiva para alunos com NEEs, nos dias atuais, surgem em condições históricas adversas às da antiguidade. Com contribuições para que esses alunos sejam reconhecidos nas suas singularidades e potencialidades para o processo de escolarização.

Nesse sentido, compreendemos a educação como uma atividade intencional e social, que se apresenta como "um processo de humanização, socialização e entrada numa cultura, singularização-subjetivação". (CHARLOT, 2006, p.15). Por meio da educação, o homem apropria-se da cultura mais elabora, tornando-se capaz de estudar determinado objeto, na sua totalidade, na sua relação com o outro, com o mundo e consigo mesmo. Nessa relação, é possível compreender o objeto na sua historicidade, apreender a sua gênese e discutir suas transformações que estão imbricadas na sua gênese.

Os alunos com necessidades educativas especiais têm no seu legado histórico registros de exclusão social e educacional, pelo fato destes apresentarem aspectos físicos, psíquicos e comportamentais considerados inadequados para as diferentes épocas da histórica da sociedade. É possível salientar que conquistar espaço na sociedade como cidadãos de direitos e deveres, sendo respeitado e com oportunidade de usufruir dos benefícios sociais, isto é, o direito à saúde, educação e lazer, é tarefa árdua, principalmente na sociedade capitalista em que vivemos.

E, quando se trata de pessoas que apresentam características psicossociais consideradas inadequadas como representação de ideal para um cidadão, em uma sociedade capitalista, certamente as dificuldades para conseguir espaço como cidadão com direitos e deveres, torna-se muito mais complexas, frente aos desafios que a sociedade capitalista impõe. É essencial para os dias atuais, a construção de significados sociais para estas pessoas que lutaram e ainda lutam para conquistar um lugar na sociedade.

Para que essa construção aconteça, devemos compreender como Marx; Engels (2002,p. 25), ao analisarem que:

Os homens são os produtores de sua representação, ideias etc., mas os homens reais, os que realizam, tal como foram condicionados por um desenvolvimento das suas forças produtivas e do modo de relações que lhe compreende, incluindo até as suas formas mais avançadas. A consciência não pode ser mais do que o Ser Consciente e o Ser dos Homens é o seu processo de vida real.

É necessário que tenhamos conhecimento da realidade objetiva, na qual estamos e somos envolvidos, e a partir desta, produzir e transformá-la, conscientemente. Oportunizando àqueles considerados diferentes/desiguais condições de igualdade social, partindo-se da atividade real dos homens.

Na contradição inclusão e exclusão é que encontramos um grupo de pessoas, com NEE's, que lutam para que tenham sua identidade reconhecida, que sejam visíveis na sociedade como pessoas com capacidades e potencialidades para o desenvolvimento social.

Que sejam incluídos na sociedade, com direitos a educação inclusiva que os possibilite ingresso e aprendizagem nas diferentes etapas da Educação básica e do Ensino Superior.

${ }^{14}$ Para conhecimento mais aprofundado da tese de Vygotski (2009), ler capítulo 7, do livro Construção do Pensamento e da Linguagem. 
Anterior à educação inclusiva, as pessoas que eram consideradas fora dos padrões de normalidade, construídos e aceitos no imaginário social, eram relegados ao extermínio, na compreensão de não apresentarem condições de contribuir para a transformação social.

Vygotski (1997) tece críticas a estes padrões culturais estabelecidos pela sociedade, que estigmatizava pessoas como anormais, pelas suas características individuais que destoam daquela que é mais comum no ambiente social.

Para Tacca (2008), tratar uma pessoa com indiferença, pelas suas características individuais, evidencia que os defeitos ou as limitações são socialmente instituídos e aparecem como uma construção social. É nessa compreensão que os alunos com NEE's incluídos na escola regular sofrem resistência frente seu processo de escolarização.

As pessoas com deficiências, transtornos globais do desenvolvimento e altas habilidades/superdotação (BRASIL, 2008), que constituem o grupo de alunos com NEE's têm, no passado, uma história de exclusão social e educacional. Estas, ainda permanecem significadas na consciência das pessoas, que em suas ações excluem e segregam esses alunos.

Mas, é nesse processo histórico social que há possibilidades de formação destas pessoas, na sua constituição enquanto seres humanos sociais.

Ao fazer referência ao processo histórico em que o ser humano desenvolve-se, Duarte (2013, p. 46) acrescenta que "o indivíduo forma-se, se apropriando dos resultados da história social e objetivando-se no interior dessa história, ou seja, sua formação realiza-se por meio da relação entre objetivação e apropriação ". Com esta compreensão, as ações a serem efetivadas no presente, quanto à educação inclusiva, não devem estar engessadas ao passado, sem possibilidade de igualdade de direitos e de transformação.

Lima (2006, p. 21), manifesta-se no sentido de contribuir para uma sociedade mais justa e igualitária afirmando que:

A importância da Educação Inclusiva, no sentido de procurar formas para superar as situações de exclusão, reconhecendo o direito a ser diferente e envolvendo toda sociedade no atendimento às pessoas com deficiências, sua tarefa é estimular a participação social plena de todos os grupos que estão em situação de exclusão.

A autora reforça a importância da educação inclusiva como reconhecimento as relações de igualdade entre todos os cidadãos. Em que os direitos sociais e de ser diferente devem ser respeitados e validados.

A educação inclusiva traz no seu bojo, conforme os autores Stainback e Stainback (1999, p. 21), o fundamento de uma proposta educacional, em que a "educação é uma questão de direitos de humanos e os indivíduos com deficiência devem fazer parte das escolas, as quais devem modificar seu funcionamento para incluir todos os alunos", não se aceitando segregar, ou mesmo excluir alunos das escolas comuns.

As discussões sobre o objeto de estudo, os significados e os sentidos da educação inclusiva constituídos nos períodos históricos da educação, apresentadas neste trabalho científico, surgiu partir da construção do trabalho final da disciplina Produção Científica III, cursada no ano de 2014, segundo semestre, no curso de Doutorado em Educação da Universidade Federal do Piauí.

0 presente estudo, que é uma pesquisa qualitativa de caráter bibliográfico, se constituiu quando das discussões sobre a Psicologia Sócio-Histórica (VYGOTSKI, 2009,

2008, 2007; LEONTIEV, 1978), sobretudo quando da apreensão das categorias: Mediação, História, Atividade, Sentido e Significado e Consciência. Tendo por base filosófica, o materialismo históricodialético, de Marx. As categorias nos ajudam a compreender o processo de constituição do humano.

Com a necessidade de aprofundar conhecimentos que desvelem sobre o objeto de estudo, isto é, os significados e os sentidos da educação inclusiva, neste estudo, foram dados ênfase a categoria significado e sentido. Em que as demais categorias estarão entrelaçadas nas discussões ora apresentadas.

Como análise das discussões teóricas ora apresentadas, apreendemos que não obstante ao progresso alcançado pela sociedade civil e educacional, no que tange a adesão e a conscientização dos benefícios que a inclusão pode proporcionar para os alunos com

necessidades educativas especiais, a inclusão encontra significados e sentidos de resistências por parte de professores, nos dias atuais. Resistência que pode ser evidenciada pelas condições reais e objetivas que 
estes professores estão sujeitos no cenário educacional. Em que os sistemas de ensino apresentam reformas educacionais, mas não são dadas as condições favoráveis para que esse professor possa aproprie-se delas, assim como manifestar-se sobre as mesmas.

Condições objetivas que possibilita apreensão de sentidos os mais diversos possíveis acerca da educação inclusiva para alunos com necessidades educativas especiais em processo de escolarização nas escolas regulares. E que, na maioria das vezes, destoam na sua totalidade do real significado desta proposta educacional. Dificultando a inclusão social e educacional destes alunos.

\section{CONSIDERAÇÕES FINAIS}

A construção de novos significados e novos sentidos sobre o objeto social torna-se um movimento desafiador para as pessoas nos dias atuais. Sobretudo se considerarmos que surgimento do novo, que tem como precedente o antigo, que traz arraigado significados e sentidos tidos como já formados, difíceis de serem superados.

Como fora apresentado pelos teóricos Vygotski (2009, 2007), Leontiev (1978), os significados e os sentidos são mutáveis, transformam-se com a evolução humana e social.

Dessa forma, foi possível apreender que as significações sociais sobre a educação inclusiva para alunos com NEEs, nos dias atuais, surgem em condições históricas adversas às da antiguidade. Com contribuições para que esses alunos sejam reconhecidos nas suas singularidades e potencialidades para o processo de escolarização.

Sentidos e significados que perpassam à exclusão destes alunos do convívio em sociedade, antes do século $\mathrm{XX}$, aos dias atuais, em que a educação inclusiva surge como proposta educacional para incluir todos os alunos indistintamente. A educação inclusiva surge para contrapor às escolas especiais, e àquelas que segregavam os alunos com NEEs, sem oportunizá-los apropriação da cultura social.

A contradição inclusão e exclusão está presente nos diferentes períodos históricos, quando se busca compreender sobre os significados e os sentidos de educação inclusiva. É possível evidenciar quando se discute sobre inclusão, a necessidade de se compreender sobre a exclusão. Reiteramos a compreensão de Sawaia (2012) ao afirmar que tanto a expressão inclusão quanto exclusão constituem-se na negação uma da outra, ao tempo em que não existem sem a outra.

Nesta contradição, é que encontramos um grupo de alunos com NEE's, que buscam mudanças nas significações sociais, prevalecendo o conceito de inclusão como atividade social, consciente e transformadora com fins a incluir alunos com necessidades educativas especiais na escola regular. Considerando os aspectos sociais, culturais, cognitivos e afetivos para o processo de escolarização, com qualidade, destes alunos. Que sejam incluídos na sociedade, com direitos e deveres sociais, possibilitandolhes ingresso, permanência e aprendizagem nas diferentes etapas da Educação básica e do Ensino Superior.

Consideramos essenciais as discussões entorno dos sentidos e dos significados da educação inclusiva, por favorecer conhecimentos sobre a temática em estudo aos diferentes profissionais que têm interessados. Bem como por propiciar reflexão crítica acerca da constituição histórica dos significados e dos sentidos da educação inclusiva, como necessário para a evolução no pensar, agir e sentir da sociedade. Especificamente da comunidade profissional, que lida diretamente com a inclusão social e educacional das pessoas com NEEs, e tornam-se responsáveis pela aprendizagem e desenvolvimento destas pessoas.

Essa apropriação e reflexão tem como finalidade a realização do movimento dialético acerca dos significados e dos sentidos da educação inclusiva, para que a sociedade em geral, possam construís seus próprios conceitos acerca desta educação. Considerando que os significados e os sentidos mudam, se transformam perante aqueles construídos em períodos anteriores ao vigente, e que não estão satisfazendo às necessidades da humanidade no momento. 


\section{REFERÊNCIAS}

[1] Brasil. Ministério da Educação/ Secretaria de Educação Especial. Política Nacional de Educação Especial na Perspectiva da Educação Inclusiva. Documento elaborado pelo Grupo de Trabalho nomeado pela Portaria Ministerial no 555, de 5 de junho de 2007, prorrogada pela Portaria no 948, de 09 de outubro de 2007. Disponível em: <http://peei.mec.gov.br/arquivos/politica_nacional_educacao_especial.pdf >. Acesso em: 06jul. 2014.

[2] Carneiro, Moaci Alves. LDB Fácil: leitura Crítico-compreensiva artigo a artigo. 4. ed. Petrópolis: Vozes, 2010.

[3] Charlot, Bernard. A pesquisa educacional entre conhecimentos, políticas e práticas: especificidades e desafios de uma área de saber. Revista Brasileira de Educação. vol.11, n. 31, p. 7-18, jan./apr. 2006.

[4] Chaves, Svendla. Inclusão para todos. Revista Escola Pública. São Paulo. Segmento. Ano v, n. 37, p. 34, fev/mar. 2014.

[5] Duarte, Newton. A individualidade para si: contribuição a uma teoria histórico-crítica da formação do indivíduo. 3 ed. Campinas, SP: Autores Associados, 2013.

[6] Ferreira, Aurélio Buarque de Holanda. Novo Dicionário Aurélio da Língua Portuguesa.2.ed. Rio de Janeiro: Nova Fronteira, 1986.

[7] Fogli, Bianca Fátima Cordeiro dos Santos. A dialética da inclusão em educação: uma possibilidade em um cenário de contradições para alunos com deficiências na rede de ensino

[8] FAETEC. Tese (Doutorado em Educação). Universidade do Estado do Rio de Janeiro. Rio de Janeiro, 2010. $173 f$.

[9] Glat, Rosana; Blanco, Leila de Macedo. Educação especial no contexto da educação inclusiva. In: GLAT, Rosana. (Org.). Educação inclusiva: cultura e cotidiano escolar. Rio de Janeiro: 7 letras, 2009. p. 16.

[10] Jannuzzi, G. de M. A educação do deficiente no Brasil: dos primórdios ao início do século XXI. Campinas, SP: Autores Associados, 2006.

[11] Jodelet, Denise. Os processos psicossociais da exclusão. In: Sawaia, Bader. As artimanhas da exclusão: Análise psicossocial e ética da desigualdade social. 12 ed.Petrópolis, RJ: Vozes, 2012. p. 61.

[12] Kopnin, P.V. A dialética como lógica e teoria do conhecimento. Trad. Paulo Bezerra. Rio de Janeiro: Civilização Brasileira, 1978.

[13] Kosik, Karel. Dialética do concreto. 7. ed. Trad. Célia Neves e Alderico Toríbio. São Paulo: Paz e Terra, 2002.

[14] Leontiev, A. N. Actividad, consciencia y personalidade. Buenos Aires: Ciências DelHonbre, 1978.

[15] Lima, M. R. e S. Inclusão escolar de alunos com altas habilidades/superdotação em escolas públicas de Teresina-PI. Dissertação (Mestrado). Universidade Federal do Piauí.Teresina, 2010.

[16] Lima, P. A. Educação inclusiva e igualdade social. São Paulo: Avercamp, 2006.

[17] Magalhães, Rita de Cássia Barbosa Paiva. (Org.). Educação inclusiva: escolarização, política e formação docente. Brasília, DF: Liber Livro, 2011.

[18] Marx, Karl. O Capital: Crítica da Economia Política. Livro I, v. I, 9. ed. São Paulo: Difel, 1984.

[19] ___ _ Engels, Friedrich. A ideologia Alemã: Teses sobre Feuerbach. São Paulo: Centauro, 2002.

[20] Mazzota, M. J. S. Educação Especial no Brasil: história e políticas públicas. 5. ed. São Paulo: Cortez, 2005.

[21] Sawaia, Bader. (org.). As artimanhas da exclusão: Análise psicossocial e ética da desigualdade social. 12 ed. Petrópolis, RJ: Vozes, 2012.

[22] Stainback, S.; Stainback, W. Inclusão: um guia para educadores. Porto Alegre: Artes Médicas, 1999.

[23] Tacca, M C. V. R. (Org.) Aprendizagem e Trabalho Pedagógico. Campinas: Alínea, 2008.

[24] Vigotski, L. S. A construção do pensamento e da linguagem. São Paulo:Martins Fontes, 2009.

[25] _ _ Pensamento e linguagem. 4. ed. São Paulo: Martins Fontes, 2008.

[26] __ Teoriae método em Psicologia. São Paulo: Martins Fontes, 2004.

[27] _. Obras Escogidas V: Fundamentos de defectologia. Madrid: Visor, 1997. Vozes,2001.

[28] Zuin, Poliana Bruno. Considerações a respeito do significado e sentido em Vygotsky e Bakthin: encaminhamentos para o ensino da língua. Trilhas pedagógicas. V. 1, n. 1, p. 23-37,Ago. 2011. 


\section{Capítulo 5}

A trajetória histórica dos estudos sobre o autismo na criança: Contribuições da psiquiatria e da psicanálise

\section{Jaqueline Tubin Fieira}

Giseli Monteiro Gagliotto

Resumo: Neste artigo apresentamos o percurso histórico-teórico das investigações sobre o autismo na criança, para a psicanálise e para a psiquiatria. 0 autismo, por ser um tema permeado de mistérios, suscita questionamentos e interesses em diferentes áreas do conhecimento. Objetivamos discutir, teoricamente, como o autismo atingiu o status atual, influenciado pelo aporte psicanalítico. Elegemos o método materialista histórico dialético. Neste, a investigação histórica e crítica acerca do autismo, se faz necessária para a compreensão da trajetória do estudo sobre a criança com autismo nos moldes atuais. Utilizamos a pesquisa bibliográfica e de abordagem qualitativa. Concluímos, em consonância com a psicanálise, que a criança com autismo, deve ser olhada e compreendida como um sujeito, para além do diagnóstico médico.

Palavras-chave: Autismo; Criança; Psicanálise; Psiquiatria. 


\section{INTRODUÇÃO}

O presente artigo tem como objeto a criança com autismo, partindo do referencial teórico psicanalítico. E também, buscarmos historicamente, os conceitos e contribuições do autismo, para a psiquiatria e para a psicanálise.

Formalmente, os primeiros estudos psicanalíticos sobre o autismo se deram nos EUA, no início do século XX, mesmo momento histórico em que o autismo começa a ser tratado como entidade clínica; ou seja, com particularidades próprias para a psiquiatria. Assim, a psicanálise encontrava-se sobre forte influência da psiquiatria e vice-versa. Como os precursores psicanalistas, nessa área, residiam nos EUA, a psiquiatria, inicialmente, teve significativa influência na incorporação do autismo pela psicanálise.

Nosso objetivo é discutir teoricamente, os aspectos que influenciaram a retomada dos debates acerca do autismo na atualidade. As discussões sobre o autismo foram intensificadas, nos meios de comunicação como rádio, internet e TV, principalmente, a partir da instituição da Lei Berenice Piana, aprovada em dezembro de 2012, que incluía o autista como uma pessoa com deficiência. Apontamos que tais veículos de comunicação têm exercido um papel importante na divulgação e informação das peculiaridades do universo autista.

Abordamos parte da história e evolução dos estudos sobre o autismo, que influenciaram os moldes contemporâneos. Propomos uma discussão teórica a respeito da evolução histórica do autismo para a psiquiatria e para a psicanálise, e apresentamos os primeiros psicanalistas que atenderam, clinicamente, crianças com autismo.

\section{METODOLOGIA}

Para embasar o referencial metodológico, inicialmente compreendemos que, conforme Lakatos e Marconi (2008) todas as ciências são caracterizadas pela utilização de métodos científicos, entretanto, nem todos os ramos de estudos que utilizam métodos são ciências. Assim, se por um lado a utilização de métodos científicos não é de uso exclusivo da ciência, por outro lado; não há ciência sem o emprego do método científico.

A partir deste entendimento, o aporte teórico que utilizamos tem o intuito de investigar como o estudo do autismo se consolidou e atingiu o status atual, para a psicanálise. 0 método de investigação que elegemos foi o materialismo histórico dialético, por meio, de uma pesquisa de cunho bibliográfico. Tal método de investigação prevê uma análise dialética sobre o autismo, na história moderna, para que se atinja a perspectiva social atual. Assim, a escolha desse método possibilitou uma compreensão crítica e dialética a respeito do autismo, regida pelas leis do capitalismo.

Entendemos, portanto, que o que apresentamos neste artigo, a partir de nossa pesquisa, se reconhece como um processo aberto e em construção, que questiona e investiga historicamente sobre a fundamentação e a contribuição da teoria psicanalítica para a compreensão do autismo na atualidade.

\section{RESULTADOS E DISCUSSÃO}

Iniciamos o presente artigo, apontando o fato, que é considerado, historicamente, o primeiro estudo sistemático do autismo infantil. Neste fato, temos, pela primeira vez, definições conceituais, divulgadas, tanto na medicina como na educação, acerca do autismo infantil, que contribuíram para a trajetória evolutiva da psiquiatria e da psicanálise infantil.

Em 1799, caçadores encontraram em um bosque, ao Sul da França, um menino, em estado quase selvagem, com aparentemente 12 anos de idade. Após 'capturado', o menino foi levado para Philip Pinel, na França. Após ser avaliado, recebeu o diagnóstico de idiota, portanto, segundo seus estudos, o prognóstico era negativo e a doença irreversível. Entretanto, Itard, discípulo de Pinel, discordou de seu mestre e defendeu o pressuposto de que o menino poderia ser educado e, consequentemente, reintegrado à sociedade, apesar de ser "privado dos conjuntos dos conhecimentos sociais e, em particular, da linguagem, devido a seu isolamento profundo" (BERCHERIE, 2011, p. 127). Victor apresentou melhoras, mas não ao ponto de reversibilidade, portanto, os estudos de Itard foram considerados um 'semi-fracasso', visto que, o menino realmente foi considerado um idiota (conforme sistema classificatório da época), entretanto, apresentou significativas evoluções com os métodos educacionais empregados pelo pesquisador (BERCHERIE, 2011). 
Sobre o caso, Feijó (2007) destaca que Itard acompanhou Victor (nome escolhido pelo próprio Itard, por significar vitória) numa instituição de surdos-mudos, para onde o menino selvagem foi enviado, após a conclusão de que ele não se comunicava e, mais grave ainda, parecia não compreender as orientações repassadas. 0 método pedagógico adotado por Itard consistia no intuito de despertar a inteligência do menino a partir de cinco metas: 1) interesse pela vida social; 2) despertar a sensibilidade nervosa; 3) ampliar a esfera das ideias; 4) levar ao uso da fala e; 5) exercitar operações da mente. Bercherie (2011) aponta que o menino Victor, foi acompanhado por Itard durante cinco anos e se tratava de um dos casos, da história da psiquiatria, publicado com maior riqueza de detalhes, inclusive nos fracassos. Fatores que chamam a atenção até os dias atuais, e que faz com que o caso, seja retomado em diversas pesquisas.

0 que também engrandece a importância e a notoriedade do caso do Menino Selvagem, como lembrado por Póstel e Quétel (1987) é o fato de que, a partir dele, os psiquiatras começaram a se debruçar no estudo das psicoses infantis, assim ele é considerado o marco histórico que desencadeou as primeiras pesquisas nessa área. Em outras palavras, as psicoses infantis representaram, a partir do caso de Itard, um novo objeto de estudo para a medicina (MARFINATI; ABRÃO, 2011).

Inúmeros autores referenciam o episódio do 'Menino Selvagem de Aveyron' como o primeiro caso publicado na história, de tratamento de uma criança com autismo. (BERCHERIE, 2011; FEIJÓ, 2007; BRANKS-LEITE e GALVÃO, 2000; PÓSTEL e QUÉTEL, 1987). Destacamos que, na época, o autismo não era considerado como entidade clínica, ou seja, classificado como uma doença. Todavia, todos os comportamentos de Victor relatados no estudo, induzem ao diagnóstico de que o menino selvagem se tratava, na realidade, de uma criança com autismo. Portanto, este caso é carregado de representações históricas e metodológicas, afinal, além de ser o primeiro caso divulgado de uma criança com autismo e de instigar, na psiquiatria, o olhar para a infância, ainda demonstra aspectos metodológicos iniciais que tornam possível a clínica com crianças com autismo.

Com a decorrência destes estudos, na década de 1820, aumentaram, significativamente, as pesquisas e as observações sobre as tentativas de tratamento para os idiotas, originadas principalmente, no Hospital de Salpetrière. Duas décadas mais tarde, ganhou destaque neste campo, o método educativo, anteriormente, utilizado por Itard, que influencia a psiquiatria infantil, representando a médico-pedagogia. Método este que, na segunda metade do século XIX, influenciou o aumento de centros voltados ao diagnóstico e tratamento de crianças idiotas (MARFINATI; ABRÃO, 2011).

0 caso do Menino Victor influenciou Séguin, um dos mais importantes alunos de Itard, na retomada dos métodos de seu mestre, originando um marco importante na história: a origem da educação especial. Nos EUA, Séguin fundou todo o sistema institucionalizado voltado para crianças 'anormais' e inspirou a nova pedagogia da época, por se tratar e um olhar para a criança e um sistema de classificação dessas crianças para as classes especiais (BERCHERIE, 2011).

Marfinati e Abrão (2011) fazem referência ao psiquiatra alemão Kraepelin por influenciar, de forma direta, o estudo sobre a doença mental, com a publicação de sua obra monumental Tratado da psiquiatria, de 1890 a 1907. 0 autor classificou uma nova forma de doença mental, aquela que afeta os pacientes prematuramente, assim, por entender que a demência aparece muito cedo, a denominou de Dementia praecox (demência precoce), mas não faz referência à psicopatologia infantil, visto que, para a psiquiatria da época, as crianças eram consideradas, unicamente, como adultos em miniaturas.

Jerusalinsky (1984) aborda a importância de Kraepelin, afirmando que, ao estabelecer a o diagnóstico da demência precoce, influenciou o aparecimento das entidades nosográficas, relativas à loucura na infância, de formas diferenciadas. Como consequência, surgem os termos 'psicose infantil' e 'esquizofrenia infantil' que antecedem o termo 'autismo' propriamente dito, ou seja, para referir-se a uma entidade clínica.

Assim, evidenciamos que a história das doenças mentais, inicialmente, entendida e nomeada como loucura, se desenvolveu lentamente, e de forma ainda carregada de pré-conceitos, hipóteses e fundamentos questionáveis. 
Fatores estes que eram agravados e até negados, quando as discussões se voltavam para as crianças, tanto que, as obras de psiquiatras importantes como Kraepelin e Bleuler não faziam referência à psicopatologia na infância.

(...) nessa época, os transtornos da conduta infantil só interessavam os psiquiatras quando pareciam conter um diagnóstico criado para adultos (...). Em suma, as enfermidades psíquicas da infância não interessavam aos psiquiatras (...). Desse modo, as doenças mentais infantis eram classificadas segundo os moldes da nosografia psiquiátrica do adulto e tinham como proposta de tratamento o emprego de métodos educacionais, ou não eram passíveis de tratamento (MARFINATI; ABRÃO, 2014, p. 249).

Bercherie (2011) enfatiza que a primeira geração dos tratados de psiquiatria infantil, nas línguas alemã, francesa e inglesa, foram publicadas, apenas na segunda metade do século XIX, mais especificamente, no final da década de 1880. Antes disso, as referências à doença mental, na infância, eram mencionadas, timidamente, e sem predominância, como Esquirol em 1838 que diferenciou uma criança mentalmente defeituosa de uma criança psicótica; o médico psiquiatra Wilhelm Griesinger (1817 - 1868) que dedicou parte do seu famoso livro (Tratado sobre patologia e terapêutica das doenças mentais), em 1845, aos problemas psiquiátricos da criança; e o psiquiatra britânico Henry Maudsley (1835 - 1918) discípulo de Griesinger, que fez referência à 'insanidade no começo da vida' em seu livro Psysiology and Pathology of the mind (Fisiologia e Patologia da mente).

Nesta mesma linha, Stelzer (2010) aponta o livro de Maudsley, publicado em 1867, como um dos marcos históricos consagrados sobre a compreensão das patologias nas crianças, mesmo reconhecendo que o capítulo voltado às crianças, se tratava de uma tentativa primitiva de relacionar o estado de desenvolvimento infantil com sintomas patológicos.

A educadora austríaca Heller também contribuiu para o desenvolvimento das pesquisas psiquiátricas e educacionais sobre o desenvolvimento das patologias na infância e introduziu o termo 'psicose infantil'. Em 1908, a educadora acompanhou seis crianças que apresentavam um quadro clínico estranho e não descrito, com propriedade, até o momento. Após o desenvolvimento, aparentemente, típico na criança, com aproximadamente 3 ou 4 anos, elas iniciavam o desenvolvimento de um quadro regressivo com características não esperadas como rápida diminuição de interesse pelo ambiente e pelas pessoas, perda da fala ou aparecimento de uma linguagem estereotipada, perda do controle esfincteriano, retardamento mental, demência com maneirismos das atividades e nos gestos (BERCHERIE, 2011; STELZER, 2010). Pesquisadores acreditavam que tais crianças deveriam ser classificadas como dementes precoces. Entretanto, ao analisar as características elencadas, as evidências tendem para o diagnóstico de autismo nas crianças observadas por Heller.

Marfinati e Abrão (2011) destacam que o caso do 'Menino Selvagem de Aveyron' estudado por Itard em meados do século XIX, além de ser considerada uma das mais importantes de toda a história da psiquiatria infantil, permite que a psicanálise inicie uma reflexão sobre o autismo, campo que era até então, exclusivo da psiquiatria. Evidenciamos, por meio deste extrato, a importância que os estudos com o Menino Selvagem representam para a história da infância, tanto para a construção das psicopatologias infantis na psiquiatria, quanto para um olhar da psicanálise para os conflitos emocionais originários na infância.

Além deste caso, que representa um importante laço entre a psiquiatria e a psicanálise, Marfinati e Abrão (2014) abordam também que, um dos primeiros entrecruzamentos da psiquiatria com a psicanálise, é originado pelo psiquiatra suíço Eugen Bleuler (1857 - 1939), ao renomear o quadro, inicialmente, proposto por Kraepelin como demência para esquizofrenia. Consequentemente, tanto a demência precoce como a precocíssima foram reclassificadas como esquizofrenia infantil. A renomeação deste novo transtorno, descoberto e observado já na criança, provocou na psicanálise estudos sobre a infância como uma etapa do desenvolvimento importante e contundente, que era negada e indiferente para os estudiosos da época.

Becherie (2011, p. 134) aponta que "a progressão da clínica psicopatológica da criança efetuou-se, essencialmente, através dos estudos dos psicanalistas e podemos dizer que ela é, cada vez menos, separável dos esforços psicoterápicos a ela consagrados". Para o autor, enquanto a clínica psiquiátrica do adulto é, originariamente, anterior à psicanálise, a estruturação da clínica psiquiátrica infantil só é possível em virtude dos estudos psicanalíticos sobre as crianças. Remontamos, portanto, a importância e o peso que a psicanálise representa para a compreensão da criança na sua totalidade, dos transtornos mentais na infância e por despertar o interesse e a possibilidade de tratamento psicológico e psiquiátrico para as crianças. 
A pioneira sobre a técnica psicanalítica aplicada com crianças foi Anna Freud (1895 - 1982) a filha caçula de Freud. Anna publicou livros importantes sobre o tema, como 'O tratamento psicanalítico de crianças' (1927), 'O ego e os mecanismos de defesa' (1936) e 'Infância normal e patológica' (1965). Mesmo sendo considerada a precursora da técnica dentro da psicanálise, Calzavara (2012) enfatiza que Anna suponha o atendimento pela via pedagógica e defendia que, na clínica com crianças, as investigações deveriam permear as manifestações do ego ao invés de focar nos conflitos do inconsciente. Defendia, portanto, que os sintomas na criança, divergem dos sintomas nos adultos.

Calzavara (2012) destaca que, o tratamento clínico com crianças, para Anna Freud, deveria, além da técnica analítica, utilizar o conhecimento pedagógico, pois reconhecia a dificuldade em utilizar a psicanálise pura com as crianças. Inclusive, "o viés educativo perpassa o tratamento psicanalítico proposto por Anna Freud" (p.57). Assim, no decorrer de sua evolução, como pesquisadora, Anna se distanciou da psicanálise, atitude que ela mesma reconheceu. Em 1927 afirmou que a técnica pedagógica associada à técnica analítica é preciosa para o tratamento clínico infantil, por entender que a criança, é um ser em desenvolvimento.

Merece destaque especial Melanie Klein (1882 - 1960), por ser a psicanalista que marcou a história com a real possibilidade do tratamento psicanalítico com crianças, ao desenvolver a técnica lúdica como uma forma de análise. Klein, auto intitulou-se uma precursora fiel de Freud, pois, aprimorou a teoria psicanalítica, ao direcioná-la para a compreensão da infância. Além de, lidar com as dificuldades da teoria freudiana, voltada para as crianças, substituiu a associação livre ${ }^{15}$ nos adultos pelo brincar nas crianças. (SOUZA, 2008). Evidenciamos que Klein, diferente de Anna Freud, estava focada em investigar o inconsciente infantil. Para tanto, entendia a brincadeira, durante a terapia, como um caminho para o inconsciente, portanto, o substituto da associação livre.

Para Souza (2008) a nova ferramenta, que permite a análise com crianças, a técnica lúdica desenvolvida por Melanie Klein, marcou o início da técnica do brincar, tanto que, em seu primeiro artigo publicado em 1919 'Desenvolvimento de uma criança' a psicanalista já fazia referência à técnica, mesmo que, neste período, ainda não a descrevia formalmente. Klein percebia que o jogo simbólico e a simbolização traziam muita utilidade para a criança, já que, a capacidade de simbolização na criança, permite que ela expresse seus conteúdos inconscientes, por meio, das representações e das identificações com personagens e brincadeiras.

Verificamos que Klein buscou aproximar o máximo possível, a técnica analítica clínica, desenvolvida por Freud, para os adultos, com a técnica clínica analítica para as crianças. Para tanto, substituiu a 'palavra' pelo 'brincar', fator que produziu uma mudança essencial na técnica psicanalítica.

Nesta mesma senda, Calzavara (2012) sublinha que, as investigações teóricas de Klein, por meio, da técnica do brincar, resultaram numa nova compreensão acerca do desenvolvimento emocional infantil, referente à exploração da fase mental mais primitiva. Souza (2008) destaca que tal exploração, se refere aos aspectos primordiais no desenvolvimento infantil. 0 principal deles é a presença do sadismo, de forma intensa na criança, manifesto pelo superego que opera, precocemente, e de forma mais rígida do que no adulto. Consequentemente, o sentimento de culpa existente, na criança, pode inibir sua expressão e seus sentimentos em relação às pessoas amadas.

Souza (2008) aponta a importância do brincar, do jogo e do simbólico sobre a capacidade de pensar, de explorar as fantasias e da autonomia desenvolvidas nas crianças, com transtornos mentais, ao lembrar que o primeiro tratamento psicanalítico de uma criança com autismo - 0 caso Dick - que foi realizado por Melanie Klein, em 1930, e publicado no seu artigo: 'A importância da formação de símbolos no desenvolvimento do ego'. Lembramos que o autismo foi considerado entidade clínica em 1940, assim Klein atendeu essa criança, antes mesmo da classificação formal do autismo, como uma doença e particularidades próprias, para a psiquiatria.

Para Petot (2001) o caso Dick, criança de quatro anos, muda e retardada, se tratava de um caso no qual as inibições do brincar e das associações livres, dificultavam a produção de material suficiente para as interpretações necessárias. Além disso, o contato frio e distante impedia a intervenção do analista, pois, não era possível nem figuração simbólica, nem manifestação afetiva durante as tentativas de aproximação da psicanalista com a criança.

\footnotetext{
15 A associação livre é o método terapêutico por excelência da psicanálise. Freud o inventou em substituição ao hipnotismo no tratamento das neuroses. Na associação livre o paciente é orientado a dizer o que lhe vier à cabeça, deixando de dar qualquer orientação consciente a seus pensamentos.
} 
Klein, ao relatar sobre o caso Dick, assinalou algumas características da criança que, posteriormente, demonstraram que se tratava de uma criança com autismo. 0 menino, de quatro anos, foi comparado a uma criança de 15 ou 18 meses, quando se observava, a pobreza de seu vocabulário e de suas realizações intelectuais. Dick, dificilmente, explanava afeto ou preocupação, com a ausência/presença, da mãe ou da babá. Raramente demonstrava interesse por alguma brincadeira ou objeto e não possuía contato com o ambiente. Não demonstrava interesse em utilizar seu pobre vocabulário, apenas repetia alguns ruídos, e quando raramente falava, o fazia de forma desconexa. Klein, concluiu que, não se tratava, apenas, da dificuldade de se fazer entender, mas na realidade, o menino também não tinha vontade de fazê-lo (AZEVEDO, 2011).

Tratava-se, portanto, de uma análise lenta e complicada e que, inicialmente, desconsertou Melanie Klein. No entanto, a partir desta análise, Klein divulgou aspectos contundentes e importantes, acerca da sua teoria sobre a psicopatologia infantil, entendida como a mais importante da história recente (PETOT, 2001).

Para Klein há "a descoberta da existência na criança pequena de formas de psicose irredutíveis àquelas observadas no adulto" (p.155). Portanto, enfatiza que o sofrimento e as psicoses observadas nas crianças estão no mesmo grau daquelas dos adultos, isso pelo fato de que, o sadismo no seu apogeu, durante a infância, precisa ser dominado pelo ego, por meio dos mecanismos de defesa e que, facilmente, assume a máscara de retardo (PETOT, 2011).

Portanto as pesquisas de Klein, entre 1927 e 1932 contribuem para o encontro das psicoses infantis, tanto com a psicanálise quanto com a psiquiatria. Petot (2011) anuncia que as teorias e a classificação de Klein tornaram possíveis e até anteciparam os progressos em relação à psicopatologia infantil, que inclusive, tiveram estudos mais detalhados e formais, somente meio século mais tarde.

Outra contribuição, tão brilhante quanto Klein, refere-se à Françoise Dolto (1908 - 1988), que também se dedicou para as possibilidades da clínica analítica com crianças. Dolto, inicia seus estudos, acerca da psicanálise com crianças, na década de 60, apoiada pela teoria lacaniana.

Rosa (2009) remonta que "a criança lacaniana é essencialmente inserida na estrutura desejante da família” (p. 66). Ao considerar essa máxima, Dolto, compreende que a criança é o efeito do desejo do Outro $^{16}$, que remonta a determinação histórica e social do sujeito. 0 inconsciente, portanto, é compreendido como uma experiência social; tais aparatos teóricos influenciaram os estudos e os atendimentos clínicos de Dolto.

A possibilidade de tratamento analítico, na França, para as crianças com patologias, foi inaugurado por Dolto na década de 30. Portanto, Dolto marca a história, como a pioneira, na França, com a utilização da técnica analítica, com crianças consideradas 'anormais' na época.

A partir dos referencias teóricos de Dolto, Kupfer (2004) aborda que, a criança com autismo, desenvolve um esquema corporal, que funciona de forma autônoma ao sujeito. De certa forma, é como se não existisse uma relação de causalidade entre o corpo e a linguagem. Este aspecto é chamado de 'viscosidade' e pode ser observado, nos casos, de crianças com autismo, que não sabem beijar seu semelhante; quando tal atitude é ensinada, este autista aprende, apenas, encostar os lábios na outra pessoa.

Dolto definiu esquema corporal, como uma ferramenta que organiza a relação entre o sujeito e o mundo. 0 esquema corporal funciona, como uma espécie de intérprete da objetivação do sujeito, e dá suporte para a imagem corporal - que existe desde a concepção, e a todo o momento. A intersubjetividade, do sujeito, é ocasionada pelo seu esquema corporal, este por sua vez, provoca a sensação de prazer, em direcionar a linguagem para o outro. Assim, a criança com autismo, apresenta dificuldade na elaboração do suporte do esquema corporal, portanto, não desenvolve o prazer pela comunicação (KUPFER, 2004).

160 termo Outro, com referência à obra freudiana, corresponde a uma conotação genérica daquele (s) que se ocupa (m) dos primeiros cuidados do bebê (RIBEIRO E FERNANDES, 2000). 
As considerações, sobre o desenvolvimento das psicopatologias, que surgem como consequências, do estabelecimento do esquema corporal, são investigadas por Dolto. Kupfer (2004) discorre que é possível notar, na criança com autismo, a aparente perda do reconhecimento das vozes dos familiares. Além de tornar-se muda, essa criança, se torna não ouvinte para as palavras humanas, absorvendo apenas os ruídos. 0 outro se torna fonte de sensações e não de percepções.

Dolto, nesses casos, pergunta pelo sujeito que deveria estar presente desde o início do nascimento. Mas seja qual for a razão, ele não assume, pela mediação de uma imagem corporal, um esquema corporal, que passa por isso a "viver sozinho, como um espécime anônimo da espécie". Há, segundo ela, uma separação entre sujeito e corpo (...). O sujeito parece retirar o desejo do seu corpo e tenta a descansar do trabalho de viver com esse corpo na realidade (KUPFER, 2004, p. 2).

Compreendemos, portanto, o significado da relação entre, o esquema corporal e a linguagem, no desenvolvimento do sujeito. Dolto (1996) relacionou a evolução do sujeito, com a capacidade de expressão de suas angústias, que vai além do corpo - entendido como o "mediador primeiro entre ele e o mundo ( $\mathrm{p}$. 54). Essas expressões, por meio de sons, gestos, sinais e linguagens mediadoras, com a intenção de traduzir a angústia humana e ter a capacidade de transcendê-la, para se relacionar com os outros, não ocorre com os autistas de maneira satisfatória.

Após este apanhado, sobre as principais influências psicanalistas, acerca da compreensão da criança, Rosa (2009) lembra que, para Anna Freud, a criança aparece sobreposta à infância. A criança persiste no que lhe permitiu imaginar um bom começo e que, consequentemente, evitaria a neurose. Nesta vertente, Klein concebeu que a análise infantil, seria uma forma de evitar as neuroses. Respaldada pelo aparato teórico mais psicanalítico, enfatizou a primeira infância, o bebê, ao teorizar um Édipo precoce, antes do Complexo de Édipo freudiano, para tornar possível a clínica com crianças pequenas. Por fim, Dolto buscou a primeira cena, compreendida como a pré-história do sujeito, no discurso de seus pais, que é impregnado pelo imaginário social. Abarcamos, a partir da explanação destas importantes contribuições, acerca da possibilidade da clínica com crianças, que a psicanálise está estruturada no que tange à compreensão e o olhar para a criança enquanto sujeito desejante.

\section{CONCLUSÃO}

Abarcamos a evolução e a trajetória histórica do autismo para a psicanálise a para a psiquiatria. Advertimos que tais áreas, representam fortes enlaces, desde o início dos estudos e descobertas acerca do transtorno do autismo.

Inicialmente a psiquiatria, voltada para o estudo da loucura e, posteriormente, voltando a atenção para os estudos, do que na época era chamado de idiotia, cursou um longo caminho para chegar ao patamar atual, sobre a compreensão da doença mental. Há momentos em que a psiquiatria e a psicanálise percorreram caminhos diferentes. No entanto, defendemos que, no tratamento de crianças com autismo, a psicanálise e a psiquiatria estejam lado-a-lado, para garantir o tratamento adequado para os sujeitos com autismo.

A psicanálise, em todo o seu percurso histórico, sofreu e sofre fortes críticas e julgamentos no que tange às suas descobertas. Em relação ao autismo, a história se repete. Ainda, observamos uma disputa teórica infundada, que parte do pressuposto da centralidade do conhecimento e da valorização excessiva de determinadas formas de tratamento, como se fossem únicas e exclusivas. Entretanto, lembramos que a psicanálise se preocupa com o autismo, desde que surgiu como abordagem de tratamento e compreensão das doenças mentais.

Durante todo o percurso histórico, destacamos as psicanalistas infantis renomadas como Anna Freud, Klein e Dolto. Suas contribuições, além de valiosas, representam a preocupação e o olhar para a criança, fatores fundantes para a psicanálise infantil. Enfatizamos, portanto, que as crianças com autismo, foram e são, realmente, olhadas pela psicanálise.

Por meio deste aporte teórico, concluímos que a grande contribuição da psicanálise está no olhar à criança com autismo para além de suas estereotipias. A criança além do autismo, buscando compreendê-la com sujeito, como construção histórica e social. Respeitando seus limites, natural em todo ser humano, entretanto, promover a escuta e o olhar para as crianças com autismo, significa, sem dúvida, a contribuição mais característica, da psicanálise para com o estudo do transtorno do autismo. 


\section{REFERÊNCIAS}

[1] Azevedo, F.C.; Autismo e Psicanálise: o lugar possível do analista na direção do tratamento. Curitiba: Juruá, 2011.

[2] Bercherie, P. A clínica psiquiátrica da criança. Tradução de Oscar Cirino. In: Cirino, 0. Psicanálise e Psiquiatria com crianças. Desenvolvimento ou estrutura. Belo Horizonte: Autêntica, 2001. P. 123-144.

[3] Calzavara, M. G. P.; (2013) Anna Freud e Melanie Klein: o sintoma como adaptação ou solução? Tempo Psicanalítico. Rio de Janeiro, 45 (1), p. 323- 338.

[4] Dolto, F. (1996). No jogo do desejo (V. Ribeiro, trad., 2a ed.). São Paulo: Ática.

[5] Feijó. M.C. O Garoto Selvagem em Três Tempos: Victor de Aveyron e uma história cultural da inteligência. In: Facon, número 18, 2007.

[6] Fernandes, L. R. O olhar do engano, autismo e o Outro primordial. São Paulo: Escuta, 2000.

[7] Gueller, A. S. e Souza, A. S. L. Psicanálise com crianças: perspectivas teórico-clínicas. São Paulo: Casapsi, 2008.

[8] Jerusalinsky, A.; Psicanálise do Autismo. Porto Alegre: Artes Médicas, 1984.

[9] Kupfer, M. C. M. Autismo: uma estrutura decidida? Uma contribuição dos estudos sobre bebês para a clínica do autismo.. In: Coloquio do Lepsi IP/Fe-USP, 5., 2004, São Paulo. $<$ http://www.proceedings.scielo.br/scielo.php?script=sci_arttext\&pid=MSC0000000032004000100005\&lng=en\&nr $\mathrm{m}=\mathrm{abn}>$. Acesso em: 17 de março 2018.

[10] Leite, L.B.; Galvão, I. Uma introdução à história de Victor de Aveyron e suas repercussões. In: Banks-Leite, L; Galvão. I. (Orgs.) A Educação de um Selvagem: As experiências pedagógicas de Jean Itard. São Paulo: Cortez, 2000. p. 11-24.

[11] Marconi, Marina de Andrade. Lakatos, Eva Maria. Metodologia Científica. 5 ed. São Paulo: Atlas, 2008.

[12] Marfinati, A.C.; Abrão, J.L.F. (2011). O pensamento psicanalítico sobre o autismo a partir da análise da revista Estilos da Clínica. Estilos da Clínica: Revista da infância com problemas, 16 (1), 14-31.

[13] Marfinati, A.C.; Abrão, J.L.F. (2014). Um percurso pela psiquiatria infantil: dos antecedentes históricos à origem do conceito do autismo. Estilos da Clínica: Revista da infância com problemas, 19 (2), 244-262.

[14] Petot, J. M. Melanie Klein I. 2a ed. São Paulo: Perspectiva, 2008.

[15] Rosa, M. D. Histórias que não se contam: o não-dito na psicanálise com crianças e adolescentes. 2 ed. São Paulo: Casa do Psicólogo, 2009.

[16] Stelzer, Fernando. Uma pequena história do autismo. São Leopoldo: Pandorga, 2010. 


\section{Capítulo 6}

\section{Estudante com transtorno do espectro do autismo no ensino superior}

\section{Eliene Nery Santana Enes \\ Renata Greco de Oliveira}

Resumo: 0 presente trabalho aborda a discussão sobre a inclusão de estudantes com diagnóstico de Transtorno do Espectro Autista no ensino superior. 0 objetivo é refletir sobre o tema, relatando a experiência realizada no Serviço de atendimento ao estudante da Universidade Vale do Rio Doce. Utilizou-se como metodologia a revisão bibliográfica em autores que têm como objeto de suas investigações esse transtorno, em artigos publicados disponíveis no site da Scientific Eletronic Library Online, e a pesquisa documental, em leis e documentos normativos das políticas públicas da educação especial. A partir da análise realizada, percebeu-se um aumento do número de estudantes portadores de deficiência na universidade em questão, especialmente a partir de 2015, provocando uma mobilização da instituição para acolhê-los. Ao acompanhar o caso de um estudante com o transtorno, foram traçadas, em conjunto, estratégias de acolhida ao estudante. Conclui-se que, apesar das muitas pesquisas realizadas e em andamento sobre o tema, as instituições de ensino superior ainda têm muito o que avançar, reconhecendo as diferenças e a necessidade da participação de todos na construção dos espaços inclusivos.

Palavras-chave: Transtorno do Espectro do Autismo. Educação Inclusiva. Ensino Superior. 


\section{INTRODUÇÃO}

O artigo apresenta a discussão sobre o processo de inclusão de estudantes com diagnóstico do Transtorno do Espectro do Autismo (TEA) no ensino superior. A Educação inclusiva nesse espaço educativo é tema de debate e indagações, uma vez que a chegada desses estudantes no meio universitário é recente. Levanta angústias e insegurança para o corpo docente, que busca compreender como lidar com as especificidades desse estudante nos processos educativos. Entende-se que esta discussão é pertinente, necessária e poderá trazer reflexões para outras situações e vivências do ensino superior. Tem-se como objetivo refletir sobre a inserção de estudantes com Transtorno do Espectro do Autismo (TEA) no ensino superior, relatando os avanços e desafios da experiência realizada no Espaço A3 - Serviço de atendimento ao estudante - da Universidade Vale do Rio Doce (UNIVALE).

Utilizou-se como metodologia a revisão bibliográfica em autores que têm como objeto de suas investigações o TEA, em artigos publicados disponíveis no site da Scientific Eletronic Library Online SciELO, e a pesquisa documental, em leis e documentos normativos das políticas públicas da educação especial. 0 artigo está organizado em uma primeira seção que faz abordagem dos aspectos conceituais do Transtorno do Espectro do Autismo e na segunda, uma reflexão sobre a educação inclusiva no ensino superior. Na terceira seção, far-se-á relato e discussão do atendimento ao estudante com TEA em uma instituição do ensino superior, a partir do seu projeto de atendimento educacional especializado na perspectiva da educação inclusiva.

\section{TRANSTORNO DO ESPECTRO DO AUTISMO (TEA)}

O termo "Autismo" (do grego autos) que significa ele mesmo, foi utilizado pela primeira vez, por Bleuler em 1911, "para designar a perda de contato com a realidade e consequentemente dificuldade ou impossibilidade de comunicação" (Belisário Filho; Cunha, 2010, p. 8). Em 1943, o psiquiatra americano Leo Kanner, acompanhou um grupo de 11 crianças que apresentavam características semelhantes e pareciam constituir uma entidade clínica única.

Desde 1938, chamaram-nos a atenção várias crianças cujo quadro defere tanto e peculiarmente de qualquer outro tipo conhecido até o momento que cada caso merece - e espero que venha receber com o tempo - uma consideração detalhada de suas peculiaridades fascinantes (Leo Kanner, 1943, apud BELISÁRIO FILHO; CUNHA, 2010, p. 8).

Pode-se dizer, em resposta a Leo Kanner, que na atualidade o autismo, tem recebido consideração nos espaços de discussões e pesquisas que se multiplicam na clínica médica e educação e assim, ampliam-se as possibilidades de entender melhor a dinâmica desse transtorno.

As primeiras publicações sobre o autismo são de Leo Kanner (1943), em Baltimore, e Hans Asperger (1944), em Viena, ambos de modo independente apresentaram relatos sistematizados de casos que acompanhavam e as respectivas hipóteses teóricas para o então desconhecido autismo (Baptista e Bosa, 2007)

As particularidades nas crianças observadas por Kanner (1943), constatava inabilidade para o relacionamento pessoal com a dificuldade em adotar uma atitude antecipatória em relação ao adulto como: inclinar o rosto, estender os braços, acomodar-se ao colo. Outras dificuldades observadas foram o atraso na aquisição da fala e a dificuldade na coordenação motora verbal em contraste com surpreendente habilidade na coordenação motora fina, evidenciada, por exemplo na habilidade para girar objetos circulares. Kanner também assinalava as dificuldades em relação as alterações no ambiente, por mínimas que fossem. Essas observações do autor são a base para das "noções contemporâneas de que o senso de previsibilidade e controle sobre a situação facilita a adaptação e a aprendizagem de indivíduos com autismo e têm implicações para as intervenções" Baptista e Bosa (2007, p. 24).

Em conclusão ao seu trabalho, Kanner apud (Batista; Bosa, 2007) postula que:

[...] o autismo origina-se de uma capacidade inata de estabelecer o contato afetivo habitual e biologicamente previsto com as pessoas, chamando a atenção para a necessidade de estudos que forneçam "critérios concretos" sobre os componentes constitucionais da reatividade emocional (BATISTA; BOSA, 2007, p. 25). 
Mas, o que é o autismo? Em uma definição sucinta trata-se da dificuldade do indivíduo, desde a primeira infância, de relacionar-se com outras pessoas, em graus acentuados. De acordo com Klin (2006), o autismo ou Transtorno do Espectro do Autista é um distúrbio no neurodesenvolvimento, que acomete os processos e os mecanismos cerebrais de sociabilidade básicos e precoces, consequentemente provoca a interrupção dos processos naturais do desenvolvimento social, cognitivo e da comunicação, que geram déficit funcionais. As manifestações desse transtorno variam imensamente a depender do nível de desenvolvimento e da idade.

Transtorno é o termo que se refere a um conjunto de características clínicas de ordem física, comportamental e queixas específicas (DSM-5, 2014). Os sintomas variam de grau de intensidade e hoje, sabemos que o autismo tem um amplo espectro, há crianças que não chegam a falar, habitam um mundo à parte e outros casos de menor intensidade e com autorrendimento funcional.

0 espectro autista, não é uma categoria única, é um contínuo e apresenta-se e diferentes graus. Estudos de Wing e Gould (1979), deram origem ao conceito de Espectro Autista quando estudaram crianças que não eram autistas, mas que apresentavam dificuldades na reciprocidade social, e na comunicação mediante um padrão restrito de conduta. "O Espectro Autista é um contínuo, não uma categoria única, e apresenta-se em diferentes graus” (Belisário Filho; Cunha, 2007).

O Manual Diagnóstico e Estatístico de Transtornos Mentais (DSM-5, (2014), destaca como caracterização do transtorno do espectro do autismo:

1. Déficits na reciprocidade socioemocional, variando, por exemplo, de abordagem social anormal e dificuldade para estabelecer uma conversa normal a compartilhamento reduzido de interesses, emoções ou afeto, a dificuldade para iniciar ou responder a interações sociais.

2. Déficits nos comportamentos comunicativos não verbais usados para interação social, variando, por exemplo, de comunicação verbal e não verbal pouco integrada a anormalidade no contato visual e linguagem corporal ou déficits na compreensão e uso gestos, a ausência total de expressões faciais e comunicação não verbal.

3. Déficits para desenvolver, manter e compreender relacionamentos, variando, por exemplo, de dificuldade em ajustar o comportamento para se adequar a contextos sociais diversos a dificuldade em compartilhar brincadeiras imaginativas ou em fazer amigos, a ausência de interesse por pares (DSM -5, 2014, p. 50).

O DSM-IV (1995), descreve alguns prejuízos relativas à interação social e à comunicação, que podem ser manifestadas pelas pessoas com autismo, além do restrito interesse interesses de atividades.

Na interação social, os danos:

[...] são amplos, podendo haver também prejuízos nos comportamentos não verbais (contato visual direto, expressão facial, gestos corporais) que regulam a interação social. As crianças com autismo podem ignorar outras crianças e não compreender as necessidades delas (DSM-IV, 199, p 66)

Na comunicação, os prejuízos também são marcantes:

[...] podem afetar habilidades verbais e não verbais. Pode haver atraso ou falta total de desenvolvimento da linguagem falada. Naqueles que chegam a falar, pode existir prejuízo na capacidade de iniciar ou manter uma conversação, uso estereotipado e repetitivo da linguagem ou uma linguagem idiossincrática (uso peculiar de palavras ou frases não possibilitando entender o significado do que está sendo dito). Quando a fala se desenvolve, o timbre, a entonação, a velocidade, o ritmo ou a ênfase podem ser anormais (ex.: o tom de voz pode ser monótono ou elevar-se de modo interrogativo ao final de frases afirmativas). As estruturas gramaticais são frequentemente imaturas e incluem o uso estereotipado e repetitivo (ex.: repetição de palavras ou frases, independentemente do significado, repetição de comerciais ou jingles) (DSMIV,1995, p. 66) 
Ainda, podemos observar com frequência:

[...] interesse por rotinas ou rituais não funcionais ou uma insistência irracional em seguir rotinas. Os movimentos corporais estereotipados envolvem mãos (bater palmas, estalar os dedos), ou todo o corpo (balançar-se, inclinar-se abruptamente ou oscilar o corpo), além de anormalidades de postura (ex.: caminhar na ponta dos pés, movimentos estranhos das mãos e posturas corporais). Podem apresentar preocupação persistente com partes de objetos (botões, partes do corpo). Também pode haver fascinação por movimentos (rodinhas dos brinquedos, abrir e fechar portas, ventiladores ou outros objetos com movimento giratório) (DSM-IV, 1995, p. 67).

Embora vivencie essas dificuldades, cada pessoa que apresenta TEA é afetada de uma maneira singular, pensa e organiza as informações de modos diferentes. Desse modo, as diferenças podem existir desde o nascimento e ser claramente percebidas a todos ou não (GROSSI; BARTOSZECK, 2018).

Hoje, sabe-se que o autismo tem um amplo espectro: crianças que não chegam a falar, inacessível aos que o rodeiam e outras com inteligência altamente funcional. Segundo Camargos Jr. (2017), a pessoa afetada por TEA, como característica geral, apresenta atraso no desenvolvimento. Encontra-se atraso na interação interpessoal, principalmente com os pares, na comunicação em geral, no entendimento de regras sociais, na percepção da realidade comum, na capacidade restrita de abstração, no autocontrole de impulsos e na aprendizagem.

Apesar dos estudos e avanços, a causa do autismo ainda é desconhecida. A intervenção deve ser a mais precoce possível, realizada por equipe multidisciplinar, que inclui psiquiatra, psicólogo, neurologista, fonoaudiólogo, fisioterapeuta, terapeuta ocupacional, dentre outros.

O diagnóstico é clinico com aplicação de escalas diagnósticas. As mais utilizadas são do DSM-V e o M-CHAT - Modified Checklist for Autism in Toddlers.

Baptista; Bosa (2007) alertam que o TEA, na maioria dos casos, é uma condição que dura para toda vida. Os indivíduos com esse transtorno terão dificuldades de viver de modo independente; sempre necessitam de cuidados da família.

No Brasil, conforme a reportagem da revista Veja (2017), há cerca de dois milhões de casos diagnosticados e muitos não notificados. Calcula-se que o número real chegue a três milhões. Esse número se deve aos avanços na área de diagnóstico e ao aumento de estudos na última década. Estima-se que o autismo acometa uma em cada 68 crianças.

\section{EDUCAÇÃO ESPECIAL NO ENSINO SUPERIOR NA PERSPECTIVA DA EDUCAÇÃO INCLUSIVA}

A Educação Especial, conforme Diretrizes da Política Nacional de Educação Especial na Perspectiva da Educação Inclusiva "é uma modalidade de ensino que perpassa todos os níveis, etapas e modalidades, realiza o atendimento educacional especializado, disponibiliza os recursos e serviços..." (Brasil, 2008). Na perspectiva da educação inclusiva, a educação especial passa integrar as propostas pedagógica e promover o atendimento às necessidades educacionais especiais de alunos com deficiência, transtornos globais de desenvolvimento e altas habilidades/superdotação e outros casos, que apresentam transtornos funcionais específicos.

A Política Nacional de Educação Especial na Perspectiva da Educação Inclusiva (2008) indica duas perspectivas importantes para o ensino superior: a criação dos núcleos de acessibilidade como instrumento da educação especial, contribuindo para o rompimento de barreiras no processo educacional e a inserção dos temas de acessibilidade e Libras nas diversas áreas de formação, o que favorece ao acolhimento da diversidade.

Nesse contexto, os processos cotidianos de inclusão por meio do conceito de acessibilidade é uma porta de entrada de indivíduos com deficiência na educação superior e o movimento na direção inclusiva, caminha no sentido de eliminar barreiras, criar acesso, equiparar oportunidades de aprendizagem. Considera-se que o espaço da universidade é porta de entrada aos que buscam acesso ao conhecimento, e a uma profissão é espaço de trânsito da diversidade e nesse cotidiano da universidade, dá-se o encontro com as diferenças e consequentemente discussões acerca da inclusão e acessibilidade de estudantes com deficiência no ensino superior que se coloca ainda, como um desafio na perspectiva da educação inclusiva. 0 processo de construção de um espaço inclusivo se dá, a partir de experiências e do reconhecimento das 
diferenças. Nesse sentido é sempre bem-vinda a iniciativa de discussões que buscam subsidiar a ação dos professores no manejo de estratégias que favoreçam a permanência desses alunos, no ensino superior.

\section{UNIVERSIDADE VALE DO RIO DOCE: O MOVIMENTO NA DIREÇÃO INCLUSIVA}

No movimento na direção inclusiva, no ensino superior exige das instituições respostas concretas na direção inclusiva as diretrizes para o ensino superior e a chegada de alunos com necessidades educacionais especiais (NEE) e nesse contexto, a Universidade Vale do Rio Doce criou, em abril de 2015, o Serviço de Apoio à Educação Inclusiva - SAE. Esta ação inclusiva, se desenha para disseminar no meio universitário as políticas públicas de inclusão (MEC), bem como, apoiar a inserção de alunos com necessidades especiais nos cursos de graduação por meio de ações pontuais de reflexão/formação sobre as mudanças atitudinais e pedagógicas necessárias para a superação de barreiras que impeçam a permanência desse público no ensino superior (SAE/UNIVALE, 2017).

Esse serviço, atende a Portaria/MEC no 3.284, de 7 de novembro de 2003, que dispõe sobre requisitos de acessibilidade de pessoas portadores de deficiências, para instruir os processos de autorização e de reconhecimento de cursos, e de credenciamento de instituições e prevê o compromisso formal da instituição em garantir a acessibilidade para pessoas com deficiência.

O SAE tem como projeto trabalhar no processo de inclusão dos estudantes, buscando favorecer a adaptação ao contexto universitário, divulgar informações sobre políticas públicas de inclusão, o públicoalvo da educação especial e a oferta do atendimento educacional especializado. Trabalha de modo interdisciplinar, com reuniões de equipe de profissionais, a partir de demanda dos coordenadores de curso, com a finalidade de trocar informações e impressões em relação ao atendimento/acompanhamento do estudante, permitindo assim o diálogo entre as diferentes áreas de conhecimentos, que possibilitem manejo de crises e dificuldades de estudantes em seu percurso acadêmico. Busca ainda, propiciar a formação docente para comunidade acadêmica, por meio de eventos em parceria com equipe de Gestão Pedagógica (GEPE) e nesse espaço, propiciar discussões e troca de experiências de inclusão (SAE/UNIVALE, 2017).

Em seu protocolo de atendimento, o SAE realiza levantamento no início do semestre letivo, dos alunos que se autodeclaram com deficiência no ato matrícula e assim, dá início ao acolhimento e os devidos encaminhamentos (solicitação de relatório diagnóstico, entrevista com familiar, reunião com professores, parcerias), conforme o caso e a demanda. Também, ocorrem situações de encaminhamentos ao serviço de atendimento especializado, por professores e coordenação, à medida que identificam casos ao longo do semestre letivo.

Outra ação positiva do protocolo de atendimento implementada pelo SAE é a construção, em parceria com professores e coordenação, de um Plano Individual de Desenvolvimento (PID), para o estudante com NEE. 0 plano é um instrumento que auxilia mapear possibilidades nas estratégias de flexibilização e adaptação curricular, no percurso de desenvolvimento acadêmico do estudante.

Observa-se, que o atendimento ofertado pelo SAE/UNIVALE ocorre em sentido amplo, não só em relação ao estudante com necessidades educacionais especiais, mas também para aqueles que apresentam dificuldades de adaptação, tanto no aspecto psicológico, como pedagógico.

Na UNIVALE, os primeiros estudantes com deficiência, chegaram antes da Política de (2008), mas especialmente a partir de 2015, essa chegada se intensificou, pulverizada em vários cursos de graduação. A seguir, apresenta-se no Quadro 1, dados do SAE /UNIVALE (2018), com número de estudantes que se autodeclaram, e têm registro nesse atendimento.

\begin{tabular}{|c|c|}
\multicolumn{2}{|c|}{ QUADRO 1 - SAE/UNIVALE } \\
$\begin{array}{c}\text { Cursos/ } \\
\text { Graduação }\end{array}$ & $\begin{array}{c}\text { Estudantes } \\
\text { atendidos }\end{array}$ \\
\hline Pedagogia & 03 \\
\hline Medicina & 05 \\
\hline Fisioterapia & 02 \\
\hline Psicologia & 18 \\
\hline Direito & 03 \\
\hline
\end{tabular}

Fonte: SAE - Estudantes com NEE/Deficiência - 2018 
Em relação aos números do quadro acima, é importante esclarecer que o estudante ao ingressar no processo seletivo ou efetivação de matrícula nos cursos de graduação, não é obrigado a identificar-se com necessidade educacional especial (NEE). Portanto, é possível que haja outros estudantes na universidade que não se manifestaram como pessoas com deficiência/NEE.

Os estudantes em atendimento no SAE, no total de 31 estudantes, identificaram-se como tendo deficiência de visão, audição, Transtorno do déficit de atenção com Hiperatividade, Transtorno psicoafetivos e Transtorno do Espectro do Autismo. Entre esses estudantes acompanhados em 2018, um deles apresenta Transtorno do Espectro do Autismo e cursa Direito, sendo o quarto estudante com TEA a ingressar neste curso, nos últimos oito anos. Conforme registros do SAE, dois estudantes trancaram matrícula no percurso, um estudante concluiu a graduação em 2017 e um estudante, está em curso. Todos os estudantes ingressam por meio de processo seletivo/vestibular, sem autodeclaração de necessidade educacional especial.

Desse grupo de estudantes identificados com TEA, somente um deles, apresentou diagnóstico e solicitou apoio do serviço de apoio ao estudante ao longo do curso, os demais foram identificados pelos professores e colegas da turma, a partir de situações, comportamentos e atitudes diferenciadas do esperado no contexto acadêmico. Nesse contexto, de inserção de estudantes com TEA no curso de direito, o SAE realizou com a turma e os professores, discussões sobre o transtorno traçando em conjunto, estratégias de acolhida ao estudante.

Ao final desse breve relato sobre o Serviço de Apoio ao Estudante (SAE) da UNIVALE, acredita-se na fundamental importância desse serviço especializado visando o bem-estar e desenvolvimento acadêmico dos estudantes com TEA e outros, ampliando espaço de discussão sobre perspectiva da educação inclusiva no meio acadêmico. Assim, visualizamos avanços no atendimento ao estudante.

Importante refletir, que a chegada de pessoas com TEA no ensino superior mobiliza a equipe gestora e docentes, no sentido de garantir acessibilidade e não cercear o direito das pessoas com TEA e outras com necessidades educacionais, que venham a ingressar no ensino superior.

\section{CONSIDERAÇÕES FINAIS}

Atualmente, muitas pesquisas sobre o TEA vêm sendo publicadas, porém, a prática pedagógica ainda evolui lentamente sendo um desafio para o ensino superior a presença do estudante com TEA. Nesse sentido as instituições de ensino superior têm papel importante na busca e oferta de capacitação continuada com participação de todos os atores das ações educacionais (professores, alunos, coordenadores, administração) e que reconheçam as diferenças e participem da construção dos espaços inclusivos (Ferrari; Sekkel,2007). Essa construção não pode ser padronizada, e sim construída e reconstruída como processo contínuo a partir da experiência e do reconhecimento das diferenças e da diversidade humana.

Ao percorrer os movimentos da direção inclusiva da UNIVALE, acima descritos, com a inserção de estudantes com TEA no ensino superior, a criação de dispositivos de inclusão, acessibilidade e permanência do estudante, o trabalho de formação de professores advindo no desconforto da desterritorialização de saberes, pode-se afirmar que o movimento da UNIVALE segue na direção inclusiva. Entende-se que o movimento é um processo de construção de caminhos, saberes e de eliminação de barreiras. Aprende-se, que a inclusão de pessoas com TEA no ensino superior, é sempre um desafio a ser vivenciado com cada estudante, os caminhos de inclusão são particulares, dizem respeito à peculiaridade de cada um. Nesse processo, "no mínimo sabemos que fomos afetados pela diferença" (Costa-Renders, 2010).

\section{REFERÊNCIAS}

[1] Baptista, C. R. Integração e autismo: análise de um percurso integrado. In: Baptista, C. R.; Bosa, C. A. (Orgs.). Autismo e educação: reflexões e propostas de intervenção. Porto Alegre: Artmed, 2007. p.127-139.

[2] Belisário Filho, J. A.; Cunha, P. A Educação especial na perspectiva da inclusão escolar: transtornos globais do desenvolvimento. Brasília: MEC, Universidade Federal do Ceará, 2010.

[3] Brasil. Ministério da Educação. Secretaria de Educação Especial. Política Nacional de Educação Especial na Perspectiva da Educação Inclusiva. Brasília: Mec/Seesp, 2008. 
[4] _. Ministério da Educação Especial. Portaria n. 3284/2003. Dispõe sobre requisitos de acessibilidade de pessoas portadoras de deficiência, para instruir os processos de autorização e de reconhecimento de cursos e credenciamento de instituições.

[5] _. Ministério da Educação Especial. Lei no 10. 436, de 24 de abril de 2002. Dispões sobre a Língua Brasileira de Sinais - Libras e dá outras providências.

[6] _. Ministério da Educação. Secretaria de Educação Especial. Decreto no 5.626, de 22 de dezembro de 2005. Regulamenta a Lei no 10.436, de 24 de abril de 2002. Mec/Universidade do Ceará, 2010.

[7] Camargos, W. Intervenção precoce no autismo: guia multidisciplinar de 0 a 4 anos. Belo Horizonte: Artesã, 2017.

[8] Costa-Renders, E. C. 0 movimento das diferenças na educação superior: inclusão de pessoas com deficiência in Inclusão - Revista de Educação Especial, v.5, n2, julho/dezembro, 2010.

[9] DSM 5 - Manual diagnóstico e estatístico de transtornos mentais (Recurso eletrônico). [American Psychiatric Association; tradução: Maria Inês Corrêa Nascimento... et al.]; revisão técnica: Aristides Volpato Cordioli... [et al.]. - 5. ed. - Dados eletrônicos. Porto Alegre: Artmed, 2014.

[10] DSM-IV. Manual diagnóstico e estatístico de transtornos mentais. Tradução de Dayse Batista. Porto Alegre: Artes Medicas, 1995.

[11] Ferrri, M. A. L.; Sekkel, C. Educação Inclusiva no Ensino Superior: um novo desafio. Psicologia Ciência e Profissão, 2007, 27 (4). Brasília, 2007.

[12] Grossi, M. G. R.; Bartoszeck, A. B. A neurociência do autismo. In: Borges, A. A. P.; Nogueira, M. L. M. (Orgs.). 0 aluno com autismo na escola. Campinas: São Paulo. Mercado das Letras, 2018.

[13] Klin, A. Autismo e síndrome de Asperger: uma visão geral. Revista Brasileira de Psiquiatria, São Paulo, v. 28, p. 3-11, maio 2006.

[14] Revista Veja. Claro enigma. N.30, ano 50, 26, Editora ABRIL, 26 de julho de 2017, p.84-91.

[15] Univale. Projeto - Inclusão de alunos com Necessidades Especiais no Curso Superior. 2017 


\section{Capítulo 7}

Contribuição da mediação no desenvolvimento das funções cognitivas em pessoa com deficiência intelectual no âmbito empresarial

\section{Glauce Virgínia M Régis}

Dayse Aparecida Santos

Resumo: A Educação Especial tem recebido um reconhecimento crescente e, atualmente, o debate sobre as necessidades educacionais especiais está na potencialidade do indivíduo e não mais na sua deficiência. Esta pesquisa tem como objetivo principal demonstrar a contribuição da mediação, utilizando o Programa de Enriquecimento Instrumental (PEI) como ferramenta para o desenvolvimento cognitivo de pessoa com necessidade de educação especial (deficiência intelectual) no âmbito empresarial, a fim de potencializar o desempenho de suas tarefas dentro da empresa. De classificação qualitativa e caráter descritivo e exploratório, foi desenvolvida em uma Instituição de Ensino privado no município de Campos dos Goytacazes, com uma funcionária com deficiência intelectual. Iniciou-se o estudo observando a funcionária e seguindo a aplicação do PEI no período de 45 dias. Ao fim do período, observamos que, mesmo em tempo limitado, a mediação da aprendizagem para o desenvolvimento das funções cognitivas da funcionária com deficiência intelectual revelou melhor desempenho de algumas de suas funções laborativas.

Palavra-chave: Educação Especial, Educação Cognitiva, Inclusão, Mercado de Trabalho. 


\section{INTRODUÇÃO}

Ao longo da história da humanidade um dos grandes desafios foi o convívio entre pessoas com necessidades especiais. Desde a Antiguidade até a Idade Média, muitos foram os casos de extermínio, discriminação e preconceito sobre esse grupo que ficava à margem da sociedade. Até o século XVIII, as noções sobre deficiência estavam sempre ligadas ao ocultismo, não havia o entendimento sobre as diferenças individuais, e a condição de deficiente era considerada imutável. (CORRER, 2003).

Com o avanço nos estudos acerca da questão, esse panorama foi sendo modificado e conquistas alcançadas, como a construção de políticas públicas que determinam como a sociedade deve conviver com esse público e respeitá- lo. Os direitos dos deficientes foram conquistados de forma gradual e a convivência com eles na sociedade tornou-se mais frequente, o que levava as pessoas a agir, interagir e reagir ao tentar integrá-lo e aceitá-lo. Nesse contexto, a Educação Especial tem recebido um reconhecimento crescente da sua importância na mesma medida que a sociedade se torna empática, reflete e aceita que a cidadania seja acessível a todos, e o debate sobre as necessidades educacionais especiais se concentre na potencialidade desse indivíduo e não mais na sua deficiência.

Alinhado a esse pensamento, a aquisição de conhecimentos básicos e a formação de habilidades cognitivas, objetivos tradicionais do ensino, constituem hoje condição indispensável para que todas as pessoas consigam, de modo produtivo, conviver em ambientes saturados de informações, e tenham capacidade para processá-las e selecionar o que é relevante.

Souza, Depresbiteris e Machado (2004) evocam Reuven Feuerstein e sua teoria da Modificabilidade Cognitiva Estrutural, desenvolvida pela crença de que a inteligência é dinâmica e modificável, construída a partir de múltiplos fatores gerais que podem relacionar-se com todos os comportamentos cognitivos. Essa teoria é a base do Programa de Enriquecimento Instrumental (PEI) cujo objetivo é mudar a estrutura cognitiva, estimular o pensamento autônomo e independente nas pessoas, tendo na mediação um importante papel, pois segundo Feuerstein cabe ao mediador despertar tal modificabilidade. Para Meier (2011) a mediação possibilita e potencializa a construção do conhecimento pelo mediado, é estar intencionalmente entre o objeto de conhecimento e o cognocente, transformando os estímulos vindos desse objeto com o intuito de que o mediado construa sua própria aprendizagem.

Para operacionalizar toda essa mediação a partir da teoria da Experiência de Aprendizagem Mediada (EAM) de Reuven Feuerstein, existem 12 componentes do comportamento do mediador que são analisados na promoção da mediação da aprendizagem. Segundo Cunha (2003), temos: 1) Intencionalidade; 2) Significação; 3) Transcendência; 4) Atenção partilhada; 5)

Experiência partilhada; 6) Regulação na tarefa; 7). Elogiar; 8). Desafiar; 9) Diferenciação psicológica; 10) Responsividade contingente; 11) Envolvimento afetivo e 12) Mudança.

Sabemos que o PEI além de ser aplicado no âmbito educacional também possui uma funcionalidade enriquecedora no âmbito empresarial, desenvolvendo a capacidade analítica, o raciocínio lógico e a autoestima dos que passam pelo programa. Com o intuito de otimizar a própria forma de pensar, o PEI proporciona no trabalho que o sujeito evite atitudes de impulsividade ou ansiedade.

De acordo com Giordano (2000), mesmo que a profissionalização de pessoas com deficiência seja um desafio para a empresa, suas possibilidades de adaptação ou inserção são maiores com o suporte de mediadores. Além disso, com o PEI qualquer pessoa, independentemente de idade ou função dentro de uma empresa, pode melhorar o desempenho cognitivo e a capacidade de aprender ou de resolver melhor os problemas diários.

Este trabalho tem como objetivo principal demonstrar a contribuição da mediação, utilizando o PEI como ferramenta para o desenvolvimento cognitivo de portador de necessidade de educação especial (deficiência intelectual) no âmbito empresarial, dando mais qualidade no desempenho de suas tarefas dentro da empresa. Dessa forma, o PEI cumpre, simultaneamente, função pedagógica e social.

\section{METODOLOGIA}

Esta pesquisa de classificação qualitativa e caráter descritivo e exploratório foi desenvolvida em uma Instituição de Ensino privado no município de Campos dos Goytacazes, com uma funcionária 
portadora de déficit intelectual. Iniciou- se o estudo com o período de observação da funcionária, seguido da aplicação do Programa de Enriquecimento Instrumental no período de 45 dias.

Os instrumentos utilizados para a coleta de dados foram selecionados de acordo com a relevância das pesquisadoras com a aplicação dos instrumentos de Orientação Espacial, Ilustrações e Desenho de Padrões para interpor a pesquisa e empregando possibilidades de respostas mais confiáveis ao nosso questionamento inicial sobre a contribuição do PEI em pessoa com deficiência intelectual no ambiente laborativo.

A observação é uma técnica de coleta de dados considerada um elemento básico de investigação científica tendo lugar de destaque em pesquisas de cunho qualitativo. Não consiste apenas em ver e ouvir, mas também em examinar fatos ou fenômenos que se desejam estudar (MARCONI; LAKATOS, 2017). As técnicas de observação escolhidas para este trabalho foram observação estruturada e em equipe realizada no local de trabalho da funcionária.

Para fundamentação de todo o trabalho, utilizou-se a pesquisa bibliográfica em livros de autores referência no tema, tais como: Fonseca (2002), Meier (2007), Souza et al. (2004) e artigos científicos sobre o tema abordado neste estudo, procurando dar suporte ao objetivo da pesquisa.

\section{RESULTADOS E DISCUSSÃO}

Para essa experiência com o PEI, selecionamos os instrumentos de Orientação Espacial (que desenvolve a representação e a flexibilidade mental), Ilustrações (que colabora na decodificação de problemas, exercita a orientação temporal, estimula a expressão oral, a definição de problemas e relações de causa e efeito) e Desenho de Padrões (que colabora na capitalização de dados, ou seja, estímulos necessários para a entrada, o processo e saída de informações).

Mesmo utilizando esses instrumentos, o padrão de mediação adotado pelas mediadoras foi de acordo com a escala da EAM (Experiência de Aprendizagem Mediada) citada por Feurstein operacionalizada nos 12 critérios de mediação citados anteriormente.

No início da pesquisa, com a aplicação do instrumento de Desenho de Padrões, a funcionária tinha que construir mentalmente um design por meio de uma série de imagens que exigia de si uma representação mental, uma antecipação de como a imagem seria composta. 0 instrumento consistia na identificação do todo sobreposto pelas partes, exigindo uma construção mental ativa. No início, a funcionária acreditou ser banal e fácil, mas ao refazer a atividade com mediação, a análise e a integração dos componentes das imagens foi mais significativa. A funcionária percebeu modificações antes não identificadas na representação mental, buscando lógica, habilidade de organização e planejamento nas posições das imagens e o controle da impulsividade.

No instrumento de Orientação Espacial, solicitamos à funcionária que realizasse a leitura atenta do que a atividade solicitava. Imediatamente, ela compreendeu que a atividade apenas solicitava, em um quadro de referência pessoal, percepções e projeções espaciais como direita, esquerda, frente e trás. Em poucos minutos de execução da atividade, a impulsividade tomou conta da realização da tarefa. Em alguns itens, quando envolvia diferentes pontos de referência no espaço pela representação mental, a funcionária necessitou da mediação da conduta de busca e escolha para a conclusão da atividade.

Já na execução do instrumento de Ilustrações, ao visualizar as imagens, a funcionária tinha que analisar cada cena e identificar um problema, ou melhor, a conclusão da suposta história. Inicialmente, ela observou poucos detalhes e de forma sintética informou às pesquisadoras a composição de objetos e personagens. Ao ser mais uma vez abordada e questionada sobre o que constava em cada cena, os detalhes nas expressões de cada personagem e o que a junção de todas essas informações nas cenas favoreceu uma interpretação e conclusão da história com mais riqueza.

Na análise do discurso feito pela funcionária da Instituição Privada observaram- se alguns pontos a serem abordados:

- o envolvimento afetivo da funcionária com mediadoras facilitando a execução dos instrumentos do PEI;

- progresso no controle do processamento de dados a cada realização dos instrumentos;

- ações de mudanças de organização diária da funcionária após a mediação como: o 
reconhecimento da ansiedade e impulsividade na execução das atividades favorecendo a tomada de decisões;

- pensamentos mais reflexivos e mais com mais reversibilidade de raciocínio.

\section{CONSIDERAÇõES FINAIS}

Na pesquisa aqui apresentada, mesmo em tempo e condições limitadas, notou- se que a mediação da aprendizagem para o desenvolvimento das funções cognitivas, a partir do PEI, com a funcionária portadora de deficiência intelectual melhorou o desempenho desta em algumas de suas funções laborativas, favorecendo além do crescimento de execução de tarefas e raciocínio a inclusão social com sentimento de pertença, desafio e regulação das tarefas.

A utilização de um sistema estruturado de intervenção potencializou a aprendizagem da funcionária e ajudou previamente na reabilitação de algumas funções cognitivas comprometidas na sua rotina de trabalho, como a tomada mais rápida de decisões e na criação mais eficaz de hipóteses na solução de problemas.

Acreditamos que iniciativa como esta deve ser adotada pelas empresas que estão contratando pessoas portadoras de necessidades especiais, pois para a funcionária a experiência com o PEI não se tornou um fim para si mesmo, reforçou um comportamento cognitivo aprendido. Além disso, proporcionou a reflexão da sua própria forma de aprendizagem, o seu autocontrole, o seu autogerenciamento na vida diária para lidar melhor com os déficits na sua atual condição cognitiva.

\section{REFERÊNCIA}

[1] Corrêa, Roberta Claro Romão. Uma Proposta de reabilitação neuropsicológica através do programa de enriquecimento instrumental (PEI). Ciência e Cognição. São Paulo, v. 14, n. 2, 2009. Disponível em: https://bit.ly/2TN9teI. Acesso em: 13 fev. 2019.

[2] Correr, Rinaldo. Deficiência e Inclusão social: construindo uma nova comunidade. São Paulo: Edusc, 2003.

[3] Cunha, A. C. B; Enumo, S. R. F.; Canal, C. P. P. Operacionalização de escala para análise de padrão de mediação materna: um estudo com díades mãe criança

[4] com deficiência visual. Revista Brasileira de educação Especial, Marilia, v.12, n.3, p.393-412, 2006.

[5] Cunha, A. Os conceitos de Zona de desenvolvimento proximal (ZDP) e Aprendizagem mediatizada sob a perspectiva de análise da interação mãe- criança. Educare, Educere, Castelo Branco, v.15, p.189-202, 2003.

[6] . Estilos de mediatização e interação mãe-criança: estratégias de promoção do desenvolvimento infantil. Psicologia: teoria, investigação e prática, Braga, v.9, p. 243-251, 2004.

[7] Fonseca, Vitor da. Modificabilidade cognitiva: abordagem neuropsicológica da aprendizagem humana. São Paulo: Salesiana, 2002.

[8] Giordano, Warzée Blache. (d) eficiência e trabalho: analisando suas representações. São Paulo: Annablume: Fapesp, 2000.

[9] Marconi, Marina de Andrade; Lakatos, Eva Maria. Técnicas de pesquisa. São Paulo: Atlas, 2017.

[10] Meier, Marcos; Garcia, Sandra. Mediação da aprendizagem: contribuições de Feuerstein e de Vygotsky. $7^{\mathrm{a}}$ ed. Edição do Autor, 2007.

[11] Souza, Ana Maria Martins de; Depresbiteris, Léa; Machado, Osny Telles Marcondes. A Mediação como princípio educacional: bases teóricas das abordagens de Reuven Feuerstein. São Paulo: Senac, 2004. 


\section{Capítulo 8}

\section{O processo de inclusão de uma criança com paralisia cerebral: Significações a partir das interações socais no cotidiano de uma pré-escola}

\section{Elton André Silva de Castro}

Resumo: Este trabalho tem como objetivo promover algumas reflexões sobre as interações entre uma criança com paralisia cerebral (chamada Laura, também denominada de sujeito focal) com parceiros de idade e suas professoras no contexto de uma sala de aula, numa escola de educação infantil pertencente à rede pública de ensino da cidade de Maceió. Busca-se compreender o processo de significação que configura modos de atuação entre Laura, as crianças e suas professoras, estabelecendo especial atenção para comportamentos e/ou habilidades manifestas pelas crianças e a natureza do foco pedagógico expresso pelas professoras quando no manejo do sujeito focal. Os dados que embasaram estas reflexões resultaram de recortes, por episódio, do material empírico produzido em estudo longitudinal desenvolvido num período de 6 meses utilizando observação videogravada das atividades desenvolvidas com o sujeito focal na sala de aula, bem como da realização de entrevistas com as três professoras que atuaram com Laura e sua família, sessões de autoscopia de episódios videogravados das atividades em sala de aula com a professora auxiliar e registros adicionais do pesquisador em diário de campo. Para esta comunicação optou-se por utilizar apenas os dados decorrentes de três episódios de interação recortados dos registros videográficos que foram analisados numa perspectiva microgenética. As análises permitem considerar que as interações no cotidiano da inclusão estão repletas de significações que indicam a prontidão de crianças de acompanhar demandas do sujeito focal, através de manifestações de cuidado e prontidão para atuar em co-participação com o adulto. Adultos apresentam dificuldades para aceitar a co-participação de crianças nas interações partilhadas com o sujeito focal, pode-se destacar a rigidez com que a professora auxiliar persegue seus objetivos pedagógicos em detrimento dos arranjos interacionais nas trocas intragrupais. Por fim, destaca-se que o papel da professora (do adulto) nas interações do cotidiano da inclusão enquanto um dos elementos fundamentais para sua configuração como prática pedagógica: a professora pode, como demonstrado no terceiro episódio, atuar em colaboração e numa perspectiva de orientação na promoção da interação entre crianças com desenvolvimento típico e necessidades especiais. Defende-se o uso reflexivo em processos formativos das análises de episódios de interação para fomentar a formação de professores na educação infantil com o intuito de aprimorar práticas pedagógicas no campo da educação inclusiva.

Palavras-Chave: inclusão. educação infantil. interação. significação.

Este trabalho, agora com algumas modificações, foi originalmente apresentado no II CINTEDI (II Congresso Internacional de Educação Inclusiva e II Jornada Chilena Brasileira de Educação Inclusiva) realizado na cidade de Campina Grande (Paraíba) no ano de 2016 


\section{INTRODUÇÃO}

Estas reflexões têm como objetivo contribuir com profissionais ocupados com processos de inclusão de crianças com necessidades específicas ${ }^{17}$, especialmente, no contexto da educação regular e infantil. Neste sentido, este texto pretende dialogar com professoras e professores de escolas regulares, oferecendo possibilidades de reflexão sobre o papel das interações entre parceiros de idade e adultos a partir do estudo de caso longitudinal de uma criança de 5 anos em seu primeiro ano de uma experiência de "escolarização"18 que vive com paralisia cerebral.

A paralisia cerebral é compreendida como uma encefalopatia crônica, não progressiva, originada por lesão pré, peri ou pós natal, afetando sujeitos no início da vida. Caracteriza-se por disfunção motora, podendo associar-se com comprometimentos cognitivos e sensoriais (ASIS-MADEIRA; CARVALHO, 2009).

Busca-se compreender o processo de significação que configura modos de atuação entre Laura (criança com paralisia cerebral, também denominada de sujeito focal), as crianças e professora, estabelecendo especial atenção para comportamentos e/ou habilidades manifestas pelas crianças e a natureza do foco pedagógico expresso pela professora quando no manejo do sujeito focal.

Entendemos que, no contexto da sala de aula, o professor produz e lança as suas palavras para o conjunto dos seus alunos promovendo o desenho de redes de possibilidades de significação. As palavras, carregadas de intencionalidade, escolhidas num repertório culturalmente estabelecido e socialmente localizado molda um quadro de referência que subordina todos os sujeitos. Fala-se numa mesma língua, na busca de haver um mesmo entendimento sobre interações, objetivos e tarefas a serem perseguidas e executadas. A cada palavra, apresenta-se um sujeito produtor de significação. Em cada ouvinte, um sujeito potencialmente capaz de decifrar, interpretar e significar (CASTRO, 2017).

Deve-se considerar que em contextos de ensino na escola regular, a palavra falada e a palavra escrita ocupam um lugar central nas interações; são carregadas de intencionalidade, conteúdo motivacional e atingem os sujeitos implicados no encontro intersubjetivo. No instante da ação executada ou a executar por sujeitos, a palavra pode adquirir poder de regulação (Vigotski, 2012b).

0 processo de comunicação não se restringe à produção discursiva, oral ou escrita. Vigotski (2012b) nos fala do gesto indicativo como um movimento da criança que é investido de valor simbólico pelo adulto; o movimento dirigido a um objeto converte-se em gesto indicativo para o outro. Nas palavras do autor (p. 149): "São as outras pessoas que conferem um primeiro sentido ao fracassado movimento da criança".

Apoiamo-nos em Pino (2005) ao adotarmos as categorias do público e do privado para ampliarmos o alcance heurístico deste processo anteriormente descrito. Este autor propõe que a relação eu-outro se refere a lugares simbólicos que demarcam um instante (podemos afirmar também instantes) de encontro entre mundos privados que se abrem à partilha, ao conhecimento e à negociação, dinâmicas do mundo público.

Para Vigotski (2012a) privamos a criança de vivenciar contextos de colaboração e trocas comunicacionais com outras crianças de nível cognitivo superior, impactando negativamente no desenvolvimento de suas funções psicológicas e processos mentais. Reconhecendo as singularidades destes mesmos processos, argumenta que o equívoco reside no fato de que devemos conceber a deficiência enquanto um processo e não como uma coisa, encerrada em si mesma.

\section{METODOLOGIA}

\footnotetext{
${ }^{17}$ A partir de Glat e Blanco (2007) e Glat e Pletsch (2011) concebemos estudantes com necessidades educacionais especiais ou específicas como aquele com demandas específicas que determinam o emprego de "diferentes formas de interação pedagógico e/ou suportes adicionais".

18 A rigor não devemos nos referir ao contexto da pré-escola e aos seus espaços de atividades como característicos de escolarização e compostos por salas de aula. No entanto, a experiência de pesquisa demonstrou que as atividades desenvolvidas, frequentemente, eram guiadas por intencionalidades pedagógicas orientadas por e para conteúdos que imprimiam qualidades às ações interventivas como claramente vinculadas a processos de escolarização. Havia um modelo pedagógico orientado para o ensino de habilidades de compreensão de temas e comportamentos que deveriam apontar para o desenvolvimento de competências que seriam requisitadas por outras professoras nas "séries ou anos" seguintes. O lúdico, frequentemente, estava a serviço de uma intenção de ensinar determinados conteúdos prévios que deveriam de algum modo apontar para um futuro onde desembocariam "num estágio de maior complexidade" em termos de desenvolvimento e aprendizagem para as crianças.
} 
Os dados que embasaram estas reflexões resultaram de recortes, por episódio, do material empírico produzido em estudo longitudinal desenvolvido num período de 6 meses (de agosto de 2015 a janeiro de 2016) utilizando observação videogravada das atividades desenvolvidas com o sujeito focal na sala de aula, bem como da realização de entrevistas com as três professoras que atuaram com Laura e sua família, sessões de autoscopia de episódios videogravados das atividades em sala de aula com a professora auxiliar e registros adicionais do pesquisador em diário de campo. Para esta comunicação optou-se por utilizar apenas os dados decorrentes de três episódios de interação recortados dos registros videográficos que foram analisados numa perspectiva microgenética.

Portanto, ao articular as perspectivas de estudo de caso e planejamento longitudinal, tem-se em mente que foi possível observar, com registros em videografia, a constituição dos significados pessoais atribuídos às diferentes experiências de vida dos sujeitos, com ênfase em episódios de interação, diálogos estabelecidos, negociação de significados e produção de sentidos subjetivos mobilizando comportamentos no contexto da sala de aula.

Elegeu-se uma criança com paralisia cerebral, menina com idade de 5 anos, que não falava e com pequena capacidade de vocalização, com movimentos limitados dos braços e mãos e basicamente sem movimento nas pernas, características que impactavam na interação social com seus parceiros de idade e adultos que lhes cercavam. A criança, denominada de sujeito focal, que chamamos de Laura, vive desde 1 ano e 4 meses com uma família substituta que lhe cuida tendo obtido judicialmente sua tutela. É aluna matriculada numa escola de educação infantil da rede pública municipal de Maceió (Alagoas), experimentando desde o final de maio de 2015 o início do seu processo de escolarização.

Com esta seleção buscou-se entender as singularidades de um processo de inclusão a partir da trajetória de desenvolvimento e aprendizagem significada no cotidiano compartilhado de uma sala de aula. Foram observados todos os procedimentos concernentes à produção de pesquisas com seres humanos que determina à legislação brasileira e, após análise de parecerista, obteve-se aprovação de sua execução do Comitê de Ética em Pesquisa da Universidade Federal de Pernambuco (UFPE).

Com o uso de filmadora digital, foram coletados dados através da videogravação de cenas do cotidiano de atividade em sala de aula. Nestas coletas, focalizou-se sempre o sujeito focal e os seus parceiros de idade e adultos com que interagiu.

A partir dos registros videográficos, foram recortados, descritos e analisados episódios interacionais, baseando-se nas propostas de Gil (2009), Pedrosa e Carvalho (2005) e Carvalho, Branco, Pedrosa e Gil (2002). Tomamos como referência a análise microgenética em sua potencialidade para estudar detalhadamente as evoluções/transformações entre "agente e situações" (MEIRA, 1994), buscando inferir as significações que são produzidas nas interações entre parceiros, no contexto empírico.

Apoiamo-nos nas propostas de Gil (2009) e Pedrosa e Carvalho (2005) para afirmar que não partiremos de hipóteses ou categorias a priori que pretendam explicar os comportamentos ou as interações. No dizer de Pedrosa e Carvalho (2005, p. 92 e 93), buscamos "alçar as regulações recíprocas inerentes ao processo interacional". Nossas unidades de análise foram elaboradas/circunscritas na observação dos "eventos interindividuais", observando tanto trocas entre díades, eventos triádicos e de pequenos grupos de sujeitos como propõem Carvalho, Branco, Pedrosa e Gil (2002).

\section{RESULTADOS E DISCUSSÃO}

O leitor acompanhará adiante a descrição de três episódios que foram recortados dos dados produzidos durante a pesquisa. Estes episódios, resumidamente apresentados, correspondem a dois momentos distintos da investigação. 0 primeiro e o segundo episódios resultaram da observação realizada em sala de aula no mês de agosto de 2015, o terceiro episódio foi obtido da coleta realizada no mês de novembro de 2015. 

auxiliar) ${ }^{19}$ e Tina (professora regente).

Na sala de aula, em uma das mesas encontram-se sentadas Laura, a sua esquerda Mônica (auxiliar de sala que cuida de Laura), Dora e Andressa. Laura está de cabeça baixa, mas com o olhar direcionado para a mesa onde, a sua frente, encontra-se uma folha de papel. Mônica estabelece como objetivo evidente ensinar Laura segurar o lápis. Toda sua atenção volta-se, pragmaticamente, a este objetivo: abrir a mão direita de Laura, posicionar o lápis na palma de sua mão e fazer com que seus dedos envolvam o lápis. A ação de Mônica é observada, com interrupções, por Andressa (que é chamada por Tânia para longe da mesa), sendo observada por Andressa e por Laura. Carolina surge na cena como alguém que se insere num contexto caracterizado pela execução de uma tarefa que, num primeiro momento, deveria mobilizar apenas Laura e Mônica. As atitudes de Carolina (segurar o lápis e aproximar-se ostensivamente de Laura) mobiliza Mônica e Laura. Um fluxo de ações conduzidas por Mônica em torno da utilização de um objeto (o lápis) sofre interferência e novas configurações se estabelecem (Carolina também quer segurar o lápis com Laura; Mônica reprova a co-participação de Carolina; Andressa recusa a presença de Carolina na mesa. A entrada em cena de Carolina retira Dora do seu lugar de expectadora das ações de Mônica. Laura reage às investidas de Mônica e à Carolina quando esta tenta segurar o lápis. Andressa reproduz a fala de Mônica quando Laura deve cooperar para deixar que ela dê continuidade ao objetivo de fazê-la segurar o lápis. 0 que é dito a Laura (por Mônica e Andressa) visa regular seu comportamento em torno da execução de uma tarefa (segurar o lápis); há um objetivo estabelecido por Mônica para o qual Laura deve acomodarse. Andressa percebe isto e busca reforçar as instruções de Mônica. Carolina, embora permaneça na mesa e bem próxima a Laura, diminui suas investidas com ela. Sorri, comenta o que disse Dora, mas não mais interfere diretamente no que executa Mônica. Carolina parece ocupar o lugar que foi de Andressa, torna-se uma quase expectadora. Andressa passa a atuar em cooperação com Mônica.

Episódio 2: A interação não permitida ou o cuidado espontâneo com Laura. Data: 10 de setembro de 2015, Duração: 6m e 59s

Sujeitos: crianças - Laura (5 anos), Andressa (4 anos) e Carolina (5 anos); adultos - Mônica (professora auxiliar) e Tânia (professora regente).

Tânia inicia a atividade, na roda, perguntando sobre o que estão estudando e ouve da turma que o tema é o circo. Todas as crianças estão sentadas no chão, Laura está na calça alcochoada e com o auxílio de Mônica para manter ereta. A sua direita encontra-se Andressa e depois dela, Lea e Rute. À esquerda de Laura estão Mônica, seguida por Carolina. Um comportamento de cooperação e cuidado, já manifesto por outras crianças em outros momentos, acentua-se na atuação de Carolina. Rute conversa com Lea e é repreendida por Tânia. Carolina coloca o braço sobre os ombros de Laura, quase abraçando e lhe beija o rosto. Mônica afasta Andressa dela. Laura está tranquila, Andressa mantém a atitude carinhosa com Laura, mas é repreendida por Tânia. Mônica tenta pegar a fralda de Andressa e ela retira-a do colo de Laura, mas Mônica consegue a fralda de volta. Andressa está atenta ao comportamento de Laura, que está movendo o corpo de modo oscilante e fazendo um barulho pelo nariz e garganta como se estivesse com algum pigarro ("Grrrr!"). Mais uma vez Tânia a repreende pois ela, aparentemente, não presta atenção no que ela fala sobre o circo. Andressa permanece atenta ao que acontece com Laura, que baba e suja sua roupa, imediatamente Mônica faz um gesto com a mão indicando que ela fica onde está, mas mesmo assim ela se abaixa e volta-se por trás de Laura indicando para Mônica onde está sujo; que repete o gesto de contenção. Novamente é chamada à atenção por Tânia. Mônica pega a fralda, limpa a boca e o colo de Laura. Laura incomodada com o nariz faz o barulhinho e arqueia seu corpo para trás. 0 que leva Mônica dizer: "Não, mulher!" e Andressa coloca a mão nas costas de Laura para segurá-la. Mônica reclama com Andressa. Laura permanece alguns segundos em posição ereta, sem auxílio e Mônica me mostra isto. Em seguida ela parece jogar-se para traz, o que faz Mônica segurá-la pelas costas e devolvê-la a posição anterior, mas ela se joga um pouco para trás e para o lado em cima de Andressa; levando-a a olhar para Laura e tocar em suas costas. Atenta, Tânia faz uma indicação pelo tom de voz e olhar em repreensão a Andressa. Laura está olhando para o lado direito da roda. Andressa permanece olhando para Tânia. Laura, então, oscila com o corpo e parece mais uma vez jogar-se para trás quando termina por cair, mais uma vez, em direção a Andressa; que volta a lhe apoiar pelas costas, mantendo sua mão nas costas dela. Mônica percebe nova

19 Foram adotadas as expressões "professora auxiliar" e "professora regente" seguindo declarações autoreferentes expressas pelas professoras de Laura, embora, em outros instantes, elas tenham suprimido estas denominações quando falavam do seu trabalho com as crianças. 
oscilação de Laura e gesticula para que Andressa pegue uma almofada que está atrás dela, para ser usada como reforço no apoio a ela. Andressa mostra-se capaz de cuidar e manter-se atenta a aula. Ao final, Mônica pedindo a almofada a Andressa sinaliza que ela pode colaborar quando solicitada e autorizada.

Episódio 3: 0 protagonismo das crianças e a atuação de Mônica.

Data: 01 de outubro de 2015, Duração: 05m e 39s

Sujeitos: crianças - Laura ( 5 anos), Linda ( 5 anos), Dora ( 4 anos), Andressa (4 anos)

Não captei desde o início das imagens da interação entre as crianças. Demorei alguns segundos para retomar a filmadora. As crianças estavam sozinhas, sem a presença de Mônica, ela tinha saído por alguns instantes. Rapidamente as crianças cercaram Laura, que estava em sua cadeira adaptada. Elas faziam com que Laura acompanhasse um brinquedo (um dinossauro) no ar, que era movido por Linda. Ao começar a fazer isto, ela me chamou ("Tio, vem ver uma coisa!") para mostrar, foi neste instante que eu decidi ligar novamente a filmadora e captar o que acontecia. Na ausência de Mônica as crianças organizam-se para interagir com Laura. Linda dirige inicialmente toda a ação. Toma a decisão de me inserir na cena e demonstra como Laura reage ao brinquedo, como seus movimentos corporais (especialmente o olhar) perseguem o objeto e os seus deslocamentos no ar. As crianças participam da cena. Mônica retorna ao grupo sem que Linda deixe seu protagonismo na execução das ações. Mônica modifica a ação de Linda: orienta que ela movimente o objeto com menos rapidez, para que Laura possa acompanha-lo no ar. Linda ajusta sua ação segundo instruções de Mônica. Mônica também modifica sua atitude com as crianças: reconhece o protagonismo de Linda, inicialmente participa da cena sem interferência, sugere mudanças a Linda, adequa-se a um arranjo grupal estabelecido em sua ausência. Linda afirma a predileção de Laura pelo brinquedo, esfregando-o no rosto dela e provocando-lhe reação de aparente satisfação. Mônica e Linda passam a interagir com Linda, mediadas pelo brinquedo. Não mais participo da cena, sou o expectador que observa e grava o que vejo. A presença de Mônica promove novo arranjo entre as crianças. Haverá um novo objetivo na interação que é usar o brinquedo do modo como Mônica orienta para Linda. Redefinido o uso do objeto por Mônica, esta encerra o momento levando Laura para sua cadeira junto a uma das mesinhas.

\section{CONSIDERAÇõES FINAIS}

As análises dos dados sinalizam elementos que colocam em discussão o papel dos adultos e de parceiros de idade quando em interação com o sujeito focal. Nas trocas interacionais uma ampla produção de significação atesta lugares de emergência dos sujeitos, de suas intencionalidades e de suas motivações.

Práticas pedagógicas orientadas para o manejo das demandas de uma criança com deficiência sinalizam diferentes potencialidades postas em exame: uma criança desejando participar do treino de Laura para que esta aprenda a segurar o lápis; outra cuidando de suas necessidades de higiene, limpando sua boca e atenta ao seu desequilíbrio; outra que demonstra ao pesquisador que ela é capaz de acompanhar e compreender que deve acompanhar um brinquedo deslocando-se no ar. Assistimos a uma menina com paralisia cerebral "movendo sujeitos em sua órbita". Laura e sua condição física mobilizam os sujeitos ao seu redor? Qual o impacto que tem a presença de Laura na sala de aula, considerando a atenção que lhe dispensam seus parceiros de idade e as professoras que dedicam-se a acompanha-la em sua trajetória escolar?

Considerando que os três episódios dizem respeito aos momentos inicial e final da coleta de dados, que coincidem com o início e quase o final do ano letivo, percebe-se uma mudança de atitude considerável de Mônica diante dos investimentos das crianças para com Laura. No terceiro episódio, diferentemente do primeiro, Mônica atua potencializando a atitude de Linda: corrige e aprimora o objetivo de Linda ao mostrar o brinquedo a Laura, ensina e esclarece que para Laura é importante que o movimento torne-se mais lento para que ela acompanhe o objetivo proposto na brincadeira. Mônica, neste momento, demonstra claramente o papel de potencialização de um espaço intersubjetivo entre as crianças.

Observando as cenas, aqui recortadas enquanto episódios, nos conduz a defesa da utilização da videografia como instrumento propício à formação de professores na medida em que as transformações ao longo do tempo sinalizam mudanças de atitude da professora diante da participação de outras crianças no manejo das potencialidades e demandas de Laura.

Defende-se, portanto, que é possível e desejável empreender esforços para que os processos de formação de professores levem em conta a ampliação de um olhar sobre as potencialidades de parceiros de idade e 
adultos atuarem na promoção de caminhos alternativos e colaborativos para o desenvolvimento de crianças com necessidades específicas no contexto das escolas regulares.

\section{REFERÊNCIAS}

[1] Assi-Madeira, Elisângela Andrade; Carvalho, Sueli Galego de. Paralisia cerebral e fatores de risco ao desenvolvimento motor: uma revisão teórica. Cadernos de Pós-Graduação em Distúrbios do Desenvolvimento, São Paulo, v.9, n.1, p.142-163, 2009

[2] Carvalho, A. M. A.; Branco, A. U. A.; Pedrosa, M. I. P.; GIL, M. S. C. de A. Dinâmica interacional de crianças em grupo: um ensaio de categorização. Psicologia em Estudo, 2002, 7(2), 91-99.

[3] Castro. Elton André Silva de. Inclusão e constituição do sujeito com paralisia no cotidiano de uma pré-escola. Tese (Doutorado em Psicologia) UFPE, 2017.

[4] Gil, I. L. DE C. Processos comunicativos de uma criança com paralisia cerebral no contexto escolar. Tese (Doutorado Processo de Desenvolvimento Humano) - Universidade de Brasília, Brasília, 2009.

[5] Glat, R. Blanco, L. "Educação especial no contexto de uma educação inclusiva. In: GLAT, R. (ORG.). Educação inclusiva: cultura e cotidiano escolas. Rio de Janeiro: 7Letras, 2007.

[6] Glat, R. Pletsch, M. D. Inclusão de alunos com necessidades especiais. Rio de Janeiro: EdUERJ, 2011.

[7] Meira, L. Análise microgenética e videografia: ferramentas de pesquisa em psicologia cognitiva. Temas em psicologia, Ribeirão Preto, 3, 1994

[8] Pedrosa, M .I .P de C. Interação criança-criança: um lugar de construção do sujeito. Tese (Doutorado em Psicologia Experimental) Universidade de São Paulo, São Paulo, 1989.

[9] Pedrosa, M. I. P.; Carvalho, A. M. A. Análise qualitativa de episódios de interação: uma reflexão sobre procedimentos e formas de uso. Psicologia: Reflexão e Crítica, Porto Alegre, 2005, 18(3), 431-442.

[10] Pino, Angel. As marcas do humano: às origens da constituição cultural da criança na perspectiva de Lev S. Vigotski. São Paulo: Cortez, 2005.

[11] Valsiner, J. Culture and the development of children's actions: a cultural-historical theory of developmental psychology. London: John Wiley \& Sons, 1987.

[12] Veiga-Neto, A. Incluir para excluir. In: Larrosa, S.; Sklliar, C. (Orgs.). Habitantes de Babel: políticas e poéticas da diferença. Belo Horizonte: Autêntica, 2001.

[13] Vigotski, L. S. Educación de las formas superiores de conducta. In: Obras escogidas III: problemas del desarrollo de la psique. Madrid/Espanã: Machado Grupo de Distribución, 2012a.

[14] Vigotski, L. S. Conclusiones: futuras vías de investigació - desarrollo de la personalidade del niño e su concepción del mundo. In: Obras escogidas III: problemas del desarrollo de la psique. Madrid/España: Machado Grupo de Distribución, 2012b. 


\section{Capítulo 9}

O lúdico como possibilidade para a aprendizagem de crianças diagnosticadas com transtorno do déficit de atenção/hiperatividade (TDAH) certificado tutoria e o papel do tutor

Eduardo Alberto da Silva

Nisia Camargo Caetano Di Nizo Fantinelli

Resumo: 0 presente artigo foi realizado no âmbito de uma pesquisa empírica. 0 tema escolhido para este trabalho denomina-se: "O lúdico como possibilidade para a aprendizagem de crianças diagnosticadas com Transtorno do Déficit de Atenção/Hiperatividade". 0 trabalho apresentou os problemas de aprendizagem diante das dificuldades mais conhecidas atualmente como: TDAH - Tipo desatento, TDAH Tipo Hiperativo/Impulsivo e TDAH - Tipo Combinado - no entanto a criança hiperativa na escola exige uma atenção especial por parte do professor, sendo necessária uma didática pedagógica voltada para as necessidades especiais do hiperativo. É preciso reconhecer a doença para buscar as atividades lúdicas que possam ajudar no tratamento e na aprendizagem desses alunos. Foram analisadas nessa pesquisa as estratégias utilizadas para potencializar a possibilidade de aprendizagem do aluno diagnosticado com o transtorno e, depois de uma intervenção, analisados os resultados dessa intervenção. Foi realizada uma pesquisa em sala de aula do ensino fundamenta I de um colégio do norte do Estado do Paraná, o foco para investigação foi um aluno de 7 anos com diagnostico de TDAH, frequentador do primeiro ano do ensino fundamental em processo de alfabetização e letramento. Foram relatadas as intervenções lúdicas potencializadas da aprendizagem desse aluno bem como os seus resultados. $\mathrm{Na}$ sequencia foi realizada uma analise qualitativa desse material onde os pesquisadores emitiram algumas considerações finais sobre o trabalho da pesquisa. Como resultados da intervenção percebeu-se aumento no rendimento do aluno com uma possibilidade maior de concentração e assimilação dos conteúdos após utilização de estratégias pedagógicas utilizando de recursos lúdicos e estimuladores da criatividade.

Palavras-chave: Atividades lúdicas. Déficit de atenção. Processos de aprendizagem. 


\section{INTRODUÇÃO}

Além da pesquisa em vasto material bibliográfico, o presente artigo é também um relato de experiência com um aluno diagnosticado por um médico neurologista como TDAH. 0 trabalho avaliativo e interventivo utilizou o lúdico, como enfoque interdisciplinar. 0 Transtorno de Déficit de Atenção e Hiperatividade é, basicamente, neurológico, caracterizado pela desatenção/falta de concentração, agitação (hiperatividade) e impulsividade. Estas características podem levar o portador a ter dificuldades emocionais, de relacionamento, decorrendo então baixos níveis de autoestima, além do mau desempenho escolar.

Ao psicopedagogo cabe uma intervenção educativa ampla e consistente no processo de desenvolvimento do paciente, mas acaba sendo de fundamental importância a função dos educadores de variar a metodologia utilizada, preparando uma aula mais dinâmica para que os educandos tenham sua atenção disparada se envolvam com a aula e como consequência aprendam o conteúdo. Ao aplicar este tipo de metodologia, proporcionamos aos alunos uma motivação com o brincar e ao mesmo tempo o querer aprender.

0 mencionado relato de experiência aponta às intervenções lúdicas e observa com atenção todas as dificuldades de aprendizagem, valorizando a intervenção através da aplicação de jogos, atividades e brincadeiras, podendo potencializar a aprendizagem e a criatividade do aluno com TDAH. O objetivo é o de oferecer maiores referenciais avaliativos e reflexões sobre o assunto para professores, psicopedagogos e

familiares. $\quad 0$ relato de experiência selecionado para este artigo apresenta alguns dados significativos sobre a importância das intervenções lúdicas, por meio de jogos, atividades e brincadeiras. Assim, pretende dentro deste contexto analisar a importância das práticas lúdicas pedagógicas, aplicadas pelos professores, na aprendizagem e no comportamento das crianças com Hiperatividade e Déficit de atenção, podendo ser um instrumento de auxílio aos profissionais que vão lidar com o portador de TDAH, indicando métodos eficazes pelo compartilhamento das experiências e conhecimentos adquiridos.

Objetivos da pesquisa

Objetivo geral

Apresentar, as possibilidades de utilização de recursos lúdicos para potencializar o processo de aprendizagem do aluno com TDAH.

Objetivos específicos

- Conceituar o Lúdico;

- Apresentar os termos usuais sobre o TDAH;

- Verificar a possibilidade de uma intervenção utilizando o lúdico dentro de um contexto pedagógico englobando o TDAH;

\section{Justificativa}

O Transtorno do Déficit de Atenção com Hiperatividade (TDAH) é um dos temas de maior relevância no campo educacional e da saúde nos últimos anos.

Segundo Bertoldi (2010) esse déficit é o transtorno mais comum em crianças e adolescentes encaminhados para serviços especializados como os neurologistas e psicopedagogos.

Recentes pesquisas demonstraram que, em mais da metade dos casos, o transtorno acompanha o individuo na vida adulta. O TDAH é definido a partir de quatro principais características que são a hiperatividade, a instabilidade de atenção (ou concentração) agitação e a impulsividade.

No âmbito da sala de aula, no que diz respeito ao ensino aprendizagem desses indivíduos, é válido buscar estratégias alternativas para que os mesmos permitam o desenvolvimento de práticas pedagógicas de intervenções pós-diagnósticos TDAH.

Diante do contexto, essa pesquisa justifica-se por ser um tema de grande importância no contexto educacional, o qual mostra o TDAH e suas práticas pedagógicas como sendo um caminho que permitirá uma aprendizagem exploratória e investigativa. Para a academia esse trabalho, trará na sua efetivação uma colaboração teórica para os casos envolvendo a aprendizagem de crianças com TDAH. 


\section{TDA/H: CONCEITO E CAUSAS}

De acordo com Passos (2010) o Transtorno de Déficit de Atenção e Hiperatividade TDA/H é uma disfunção neurobiológica e crônica que acompanha a pessoa por toda a vida por ter causa e predominância genética. Trata-se de uma condição que afeta crianças, jovens e adultos, conforme descrição do DSM IV - Manual Diagnóstico e estatístico de Transtornos Mentais (2005).

É um transtorno que se caracteriza por problemas de atenção, hiperatividade e impulsividade (PASSOS, 2010).

Para Albano et al., (2012, p. 55 apud GOROSTEGUI, 2006) o TDA/H se constitui como sendo o transtorno do déficit de atenção com hiperatividade um dos mais importantes transtornos do desenvolvimento dentre os problemas que afetam as crianças em suas relações com seus meios familiar, escolar e social, ou seja, é um transtorno que faz com que o indivíduo não cumpra o papel esperado frequentemente, além do que transtorna a ordem, altera a forma de organização estabelecida e acaba por acarretar problemas para o meio que está inserido e para si próprio.

Dentro do contexto, Barkley (2008, p. 36) menciona o transtorno TDA/H como sendo:

[...] o transtorno de déficit de atenção e hiperatividade ou TDA/H, é um transtorno de desenvolvimento do controle que consiste em problemas com os períodos de atenção, com o controle do impulso e com o nível de atividade. Esses problemas são refletidos em prejuízos na vontade da criança ou em sua capacidade de controlar seu próprio comportamento relativo a passagem de tempo em ter em mente futuros objetivos e consequências (BARKLEY, 2008, p. 36).

Dessa forma, o TDA/H torna-se um obstáculo para o individuo, pois o portador desse transtorno não consegue dirigir sua atenção por muito tempo para uma determinada atividade, bem como pode apresentar impulsos descontrolados que podem prejudicar sua conduta perante os demais.

Mattos (2007, p. 11) conceitua o TDA/H de uma maneira de fácil entendimento, onde leigos e estudiosos compreendem a pessoa com TDA/H:

[...] como a que tem dificuldade em manter a atenção. É comum dizer que vivem no mundo da lua, isto é, estão sempre pensando em outra coisa [...] na maioria dos casos, essas pessoas também são inquietas, não permanecem paradas nem sossegadas por muito tempo e detestam coisas monótonas e repetitivas, além de serem impulsivas no seu dia a dia (MATTOS, 2007, p. 11).

De acordo com o autor, as pessoas diagnosticadas com transtorno de déficit de atenção/hiperatividade vivem trocando de interesse e são totalmente inquietas, ainda sim, são indivíduos que em raros casos levam as coisas que estão fazendo até a conclusão, pois as mesmas têm total dificuldade de concentração e vivem trocando de interesses.

No que diz respeito as causas, Bertoldi (2010 apud SILVA, 2009, p. 176) menciona que ao longo da história várias foram as causas atribuídas ao TDA/H. Atualmente de acordo com muitas pesquisas e estudos, sabese que o déficit de atenção deriva de um funcionamento alterado nos neurotransmissores (dopamina) (quantitativa e/ou qualitativa no interior dos sistemas cerebrais) que são responsáveis pelas funções da atenção, impulsividade e atividade física e mental no comportamento humano.

Não se trata de lesões como se pensava antigamente, mas sim de uma disfunção. 0 cérebro da pessoa com TDA/H não difere em nada do cérebro de uma pessoa sem o déficit (BERTOLDI, 2010).

Silva (2009) ainda ressalta que outra causa bastante estudada são os fatores genéticos, os quais segundo pesquisas esses fatores desempenham um importante papel na gênese do TDA/H.

Bertoldi (2010) menciona outras causas, sendo ele, os fatores ambientais (externos), esse fator desempenha um papel fundamental na etiologia do TDA/H, também são encontrados inúmeros estudos associando o transtorno a complicações durante a gravidez e no parto. 


\section{TIPOS DE TDA/H}

A hiperatividade era considerada há tempos atrás, como sendo a característica mais marcante da Hiperatividade e Déficit de Atenção. No entanto, foram diagnosticados, diferentes tipos como: TDAH Tipo desatento, TDAH - Tipo Hiperativo/Impulsivo e TDAH - Tipo Combinado.

Transtorno de Déficit de Atenção, apresenta dificuldades em prestar atenção a detalhes ou comete erros por descuido em atividades escolares, tem dificuldade para manter a atenção em tarefas e/ou atividades lúdica, parece não ouvir quando lhe dirigem a palavra, tem dificuldade em seguir instruções, não termina seus deveres escolares, tem dificuldade para organizar tarefas e atividades, com frequência evita ou reluta em envolver-se em tarefas que exijam um esforço mental continuado (como tarefas escolares ou deveres de casa), com frequência perde coisas necessárias para tarefas ou atividades (brinquedos, livros, lápis ou outros materiais de trabalho), distrai-se com facilidade, apresenta esquecimento em atividades diárias (um tempo curto de memória).

Esses alunos tanto na escola como em casa, na maioria das vezes não conseguem terminar seus deveres, e também não conseguem acompanhar o que ocorre em sala de aula. Mas, sua falta de atenção pode não ser percebida, já que é um aluno cooperativo e quieto.

As crianças portadoras de TDA do Tipo Desatento são vistas simplesmente como lentas no aprendizado, a despeito do fato de a maioria ter inteligência média ou acima da média. Seus esquecimentos e sua desorganização, no entanto são vistos como sinais de capacidade intelectual limitada e não comosinais de TDA. (PHELAN, 2005, p. 38)

0 Transtorno Hiperativo/Impulsivo apresenta inquietação, mexendo as mãos e os pés ou se remexendo na cadeira, dificuldade em permanecer sentado, corre sem destino ou sobe nas coisas excessivamente, tem dificuldade em concentrar-se numa atividade silenciosamente, fala excessivamente, responde as perguntas antes de elas serem formuladas, apresenta muita agitação e tem dificuldade em esperar sua vez.

Apresentam dificuldade em concluir tarefas sequenciais, maior número de repetência escolar, agitação motora, dificuldade de controlar os impulsos, inquietação, atividade excessiva. (BARKLEY, 2008)

Hiperatividade significa inquietação motora excessiva e agressiva, não apenas espasmos de nervosismo. (PHELAN, 2005)

Transtorno de Hiperatividade Tipo Combinado é caracterizado pela pessoa que apresenta os dois tipos desatento e hiperativo / impulsivo, que apresentam um maior comprometimento nas funções executivas, um grande número de erros em atividades que necessitam de maior atenção, concentração e organização. "Por causa de sua dificuldade com regras e com o autocontrole, a criança com TDA do Tipo Combinado é muitas vezes uma significativa força negativa na sala de aula". (PHELAN, 2005, p. 35)

De acordo com o psiquiatra Ênio Roberto de Andrade, a hiperatividade só fica clara no período escolar, quando é necessário aumentar o nível de concentração para aprender. "O diagnóstico clínico deve ser feito com base no histórico da criança". Por isso, a observação de pais e professores é fundamental. (Andrade, 2000).

\section{CONCEITUANDO O LÚDICO}

A palavra lúdica origina do latim ludus que significa jogos infantis ou recreação. As brincadeiras permitem às crianças divertirem-se enquanto, ao mesmo tempo, aprendem sobre um determinado assunto. $\mathrm{Na}$ maioria das vezes os brinquedos ou brincadeiras ajudam no desenvolvimento da vida social da criança, em especial aquelas usadas em jogos lúdicos.

Os jogos e brincadeiras são fundamentais para o desenvolvimento e a educação da criança, por facilitar o desenvolvimento simbólico, estimular a sua imaginação, a sua capacidade de raciocínio e sua autoestima. (PIAGET, 1998). As brincadeiras permitem que a criança liberte a tensão, frustração, insegurança e até mesmo a agressividade, medo e a confusão, sem que a criança perceba que tem todos esses sentimentos.

A intervenção do brinquedo leva à descoberta, à experimentação e à reinvenção. A criança, em contato com o brinquedo, desenvolve a imaginação, mas também desenvolve a capacidade de análise, de comparação e de criação. Desenvolvendo, habilidades que enriquece seu mundo interior, participando do mundo real. 0 brinquedo, em sua simplicidade, é capaz de prover de recursos para a vida da criança que necessita de um processamento mais ordenado para seu desenvolvimento. 
A realidade do mundo dos adultos deve ser suavizada para o universo infantil e o brinquedo cumpre esta tarefa e o brinquedo cumpre esta tarefa. A socialização se faz completa quando pode a criança experimentar no jogo e no brinquedo suas reações, aprendendo a se conhecer. (Vygotsky e Leontiev, 1988) entendem que as atividades lúdicas não se ligam unicamente ao prazer, pois a imaginação e as regras são características que servem para definir a brincadeira, mesmo que a lógica estabelecida pela situação do jogo não seja formal.

A criança demonstra ser capaz de conhecer e resolver os problemas impostos pela vida, precisamente, por já ter experimentado o conhecimento e solução de problemas, seja criando ou invertendo regras durante o jogo. Leontiev entende que na atividade lúdica a criança desenvolve sua habilidade de sujeitar-se a certas regras, pois, "dominar as regras significa dominar seu próprio comportamento, aprendendo a controlá-lo, aprendendo a subordiná-lo a um propósito definido" (Leontiev, 1988: 139).

\section{PROCESSOS DE APRENDIZAGEM COM CRIANÇAS COM TDA/H}

Neste processo de aprendizagem é preciso que os professores conheçam um pouco sobre o TDAH, para não criarem barreiras em relação ao aluno ou dar uma maior atenção a quem possui o transtorno. Para trabalhar com essas crianças o ideal seria turmas pequenas, sentar próximo ao quadro e ao professor, sala com poucos detalhes que possam dispersar a atenção, permissão especial para ter mais tempo de fazer as tarefas sem punições, desta forma podendo contribuir para o desenvolvimento desse aluno.

É fundamental um ambiente de aprendizagem adequado, durante as aulas os professores devem controlar, estimular e motivar as aprendizagens, as tarefas devem ser curtas e bem definidas, pedir à criança que fale o que está a fazendo para que isso aumente assim a sua atenção, supervisão mais frequente das tarefas.

Dar informação suficiente às crianças para que ela possa compreender a atividade, registrar a evolução e/ou dificuldades da criança, preparar atividades de modo que a criança possa se isolar das outras quando necessário e programar atividades onde a criança possa se expressar corporalmente.

\section{UTILIZANDO O LÚDICO: JOGOS, BRINQUEDOS E BRINCADEIRAS}

De acordo com Costa (2005) a palavra lúdico vem do latim ludus e significa jogos ou recreações. Neste brincar segundo Rau (2007) estão incluídos os jogos, os brinquedos e as brincadeiras, a qual remete-se a palavra relativa também à conduta daquele que jogam, que brincam e que divertem.

Valle (2011) menciona que Winnicott (1975), Piaget (1978), Vygotsky (1991) e Huizinga (1992) caracterizam as atividades lúdicas como sendo experiências culturais que possibilitam maior compreensão do mundo.

Segundo Valle (2011) os jogos e as brincadeiras no contexto bibliográfico é muito antigo, para o autor, o seu conceito e concepções mudam de acordo com a época. Ou seja, a cada tempo histórico, a construção social dos jogos, brinquedos e brincadeiras foi se formando. Assim, o conceito atual volta-se ao divertimento, o qual significa um aprendizado voltado ao lúdico (VALLE, 2011; OLIVEIRA, 2007).

Valle (2011) ressalta que o conceito de jogo relaciona-se ao teor brincadeira, ao divertimento. Sobre o etimológico de Jogo o autor relaciona a palavra "jacu", que é decrescente da palavra gracejo (VALLE, 2011).

Araujo (1992, p. 64) conceitua o jogo como sendo "uma atividade espontânea e desinteressada, admitindo uma regra livremente escolhida que deve ser observada, ou um obstáculo deliberadamente estabelecido, que deve ser superado", ou seja, o jogo ao mesmo tempo que pressupõe liberdade de ação, necessita ter finalidade para vencer os obstáculos que se interpõem no contexto pedagógico.

Por sua vez, o jogo segundo Rau (2007), oportuniza a aprendizagem do sujeito e o seu desenvolvimento, nesse contexto, o lúdico proporciona o aprender pelo jogo e, logo, o aprende brincando. Rau (2007, p. 33 apud KISHIMOTO, 1997) menciona que o significado atual de jogo na educação divide-se em duas funções, as quais seguem:

[...] a primeira seria a função lúdica do jogo, a qual expressa na ideia de que sua vivência propicia a diversão, o prazer, quando escolhido voluntariamente pela criança, a segunda seria a função educativa, quando a prática do jogo leva o sujeito a desenvolver seu saber e seus conhecimentos, com apreensão de mundo. 
Para Rau (2007 apud Kishimoto 1997) o equilíbrio entre as duas funções seria o objetivo do jogo educativo, o qual é visto como sendo um poderoso instrumento que tem o poder de englobar uma significação.

Rau (2007) cita que a utilização do lúdico como recurso pedagógico na sala de aula pode aparecer como um caminho possível para ir ao encontro da formação integral das crianças e do atendimento de suas necessidades.

Já os brinquedos na visão de Kishimoto (2002) voltam-se a um objeto, o qual segundo o autor é o que dá suporte a uma determinada brincadeira. Nesse contexto, Valle (2011) cita o brinquedo como sendo a estimulação para que uma determinada brincadeira seja realizada, "um transporte para o mundo imaginário" (VALLE, 2010, p. 33).

A brincadeira por sua vez, Kishimoto (2002) cita como sendo atividades espontâneas, as quais acontecem em grupo ou até mesmo sozinhas. Nesse contexto, Rau (2007) menciona a brincadeira infantil como sendo aquela que possibilita à criança imitação de diferentes papéis, comumente de seu cotidiano, ação que facilita a expressão de sentimentos e relações que estabelecem com as pessoas do seu meio.

Na observação do contexto da pesquisa, notou-se que os jogos e as brincadeiras em como estratégias pedagógicas são essenciais na formação e no desenvolvimento da criança.

\section{ATIVIDADES LÚDICAS E A APRENDIZAGEM DAS CRIANÇAS COM TDA/H}

As atividades lúdicas facilitam a aprendizagem, favorecem a socialização e a colaboração entre os alunos. A escola deve motivar as atividades lúdicas para melhorar a aprendizagem, propondo atividades desafiadoras que proporcionem a construção de conhecimentos, dando oportunidades ao aluno com TDAH de ser mais criativo, participativo e ativo, levando-o a adquirir atitudes de respeito, dignidade e solidariedade, sendo necessário que o professor elabore aulas apropriadas e diversificadas, saindo da rotina.

O lúdico deve ser trabalhado de forma diversificada, com o objetivo de ser uma aprendizagem motivadora. 0 professor também deve motivar os alunos para a construção de conhecimentos, as crianças sentem-se mais motivadas, enquanto constroem seu conhecimento, vão adquirindo boas relações e se adaptando ao meio.

Lopes (2000, p. 47) afirma "o exercício de jogos competitivos, quando são trabalhadas as emoções dele decorrentes, faz com que a criança internalize conceitos e possa lidar com seus sentimentos dentro de um contexto grupal, o que prepara para a vida em sociedade".

É de grande importância o papel do professor, devendo ordenar e incentivar seus alunos nos processos de ensino e aprendizagem.

\section{CONSIDERAÇÕES FINAIS}

Neste trabalho, propomos o início de pesquisas para intervenção utilizando o lúdico na aprendizagem de crianças com TDA/H, por ser um problema complexo e necessário que deve ser levado a sério, devendo ser tratado na infância com o intermédio do professor que precisa estar preparado para lidar com essas crianças na escola.

O conhecimento a respeito desta perturbação prepara os professores para lidar com esta problemática sabendo como agir e distinguir uma criança indisciplinada, de uma com déficit de atenção, hiperatividade ou hiperativo-impulsiva. Em casos mais graves, exige-se uma ação multidisciplinar: pais, professores, médicos, medicamentos e terapeutas.

As atividades lúdicas e jogos didáticos são uma ferramenta de grande importância para aprendizagem dos alunos com TDA/H, pois o jogo não é apenas um momento de descontração e brincadeira, mas também é um momento no qual os alunos se veem motivados e incentivados. Quando as crianças "brincam", demonstram prazer e alegria em aprender. A utilização do jogo como método de ensino possibilita aos alunos um momento diferente das aulas normais, onde eles sentem-se mais interessados. Após análise dos resultados obtidos com "as atividades lúdicas" tornou-se evidente a importância e a necessidade dos jogos como instrumento no processo de ensino de um aluno com TDA/H. Além disso, conforme Teixeira, (2005) o jogo didático possibilita que o aluno compreenda os seus limites e respeite o colega. 
Este estudo mostra que as atividades lúdicas podem contribuir e enriquecer o desenvolvimento intelectual e social do hiperativo. Sendo um instrumento motivador e facilitador da aprendizagem. Conclui-se que os jogos e brincadeiras podem e devem ser utilizados como recursos didáticos dentro e fora da sala de aula, pois produz ótimos resultados na aprendizagem, dos alunos com TDAH. 0 aluno, foco da investigação dessa pesquisa pareceu ter desenvolvido de maneira mais satisfatória suas atividades acadêmicas. Quanto o mecanismo de atenção, ficou claro uma sensível melhora nas produções e comportamentos do aluno, porém as intervenções lúdicas precisariam de maior participação no currículo e espaço com disponibilidade do trabalho do professor para uma atenção maior ao indivíduo com necessidades especiais para que pudéssemos ter um rendimento ainda melhor e contribuir para a transformação dessas realidades através da efetivação das politicas públicas no sentido de inclusão definitiva desses indivíduos.

\section{REFERÊNCIAS}

[1] Albano, A. M. S. A Criança com Tdah: metodologias e adaptações curriculares. Curitiba: Fael, 2012.

[2] Andrade, Ê. R. Indisciplinado ou hiperativo. Nova Escola, São Paulo, n. 132, p. 30-32. Maio 2000.

[3] Araujo, V. C. Aprender a brincar, aprender a viver. São Paulo: Manole, 1992.

[4] Barkley, A. R. Transtorno de déficit de atenção/hiperatividade. Manual para diagnóstico e Tratamento. Porto Alegre, RS Artmed, 2008.

[5] Bertoldi, M. E. Psicologia da Aprendizagem. Curitiba: Fael, 2010.

[6] COSTA, S. A formação do professor e suas implicações éticas e estéticas. Psicopedagogia on line. Educação e saúde mental. 28 de junho de $2005 . \quad$ Disponível em: <http://www.psicopedagogia.com.br/artigo/artigo.asp?entrID=692>Acesso $\quad$ em: $20 . \quad$ Agosto. 2009. Kishimoto, T. M. 0 jogo e a educação infantil. 2ª ed. São Paulo: Pioneira Thomson Learning, 2002.

[7] Lopes, M. G. O jogo e suas aplicações. In: . Jogos na educação: criar, fezer e jogar. 3 ed. São Paulo: Cortez, 2000. cap.1, p. 35-47.

[8] Mattos, P. No mundo da Lua. São Paulo, Lemos, 2007.

[9] Oliveira, Z. R. de. Educação Infantil: fundamentos e métodos. 3ª ed. São Paulo: Cortez, 2007.

[10] Passos, M. O. A. Fundamentos das dificuldades de aprendizagem. Curitiba: Fael, 2010.

[11] Phelan, T. W. TDA/Tdah. Transtorno de Déficit de Atenção e Hiperatividade: Sintomas, Diagnósticos e Tratamentos. Crianças e Adultos. São Paulo: M. Books do Brasil Editora, 2005.

[12] Piaget, J. A psicologia da criança. Ed Rio de Janeiro: Bertrand Brasil, 1998.

[13] Rau, M.C.T.D. A ludicidade na educação: uma atitude pedagógica. 20 ed. Curitiba. Ibpex, 2007. 164 p.

[14] Silva, A.B.B. Mentes Inquietas. Tdah: desatenção, hiperatividade e impulsividade. Rio de Janeiro: Fontanar, 2009.

[15] Teixeira, M. C. ; Rocha, L. J. P. ; Silva V. S. Lúdico : Um Espaço para a Formação de Identidades. In: Simpósio de Formação de Professores de juiz de Fora, 3.,2005. Rio de Janeiro. Anais... Rio de Janeiro: Cederj, 2005. p. 1-14.

[16] Valle, L.L.D. Fundamentos da Educação Infantil. Curitiba: Editora Fael, 2010.

[17] _ J J J _ _ _ _ Regos, Reação e Educação. Curitiba: Editora Fael, 2011.

[18] Vygotsky, L. S. Aprendizagem e desenvolvimento intelectual na idade escolar. In:

[19] Vygotsky, L. S; Luria, A R; Leontiev, A. N. Linguagem, desenvolvimento e aprendizagem. Tradução de Maria da Penha Villalobos. 2. ed. São Paulo: Ícone, 1988. p. 103-117. 


\section{Capítulo 10}

"Tenho problema de cabeça, por isso não aprendo": Devolvendo o lugar de protagonismo a alunos medicalizados

\section{Aline Frollini Lunardelli}

Janaina da Cruz Martins Lizze

Mariana Santana Facina

Resumo: Este texto apresenta um relato de experiência, que é parte de um projeto de extensão, realizado com alunos do ensino fundamental de uma escola municipal do interior do Paraná. Tivemos por finalidade questionar as tradicionais avaliações pedagógicas, médicas e psicológicas a que são submetidas crianças dos primeiros anos do ensino fundamental consideradas por seus professores como possuidoras de problemas de aprendizagem e, em alguns casos, com sério comprometimento cognitivo, social e afetivo. A fim de movimentar relações de ensino e de aprendizagem cristalizadas, especialmente pelo mecanismo de medicalização e reprovações frequentes, foram desenvolvidas intervenções no formato de oficinas pedagógicas com um grupo de crianças que não correspondiam às expectativas de desempenho e de comportamento estabelecidas pela instituição escolar, além de reuniões com pais e reflexões junto aos professores e à equipe pedagógica. Partindo de uma perspectiva crítica de Educação e de Psicologia, propusemos ações diferentes das tradicionalmente feitas em sala de aula, para resgatar as habilidades dos alunos participantes e promover o estabelecimento de novas relações escolares que destacassem a criança como protagonista em favor de seu desenvolvimento. 0 trabalho coletivo demonstrou que os alunos podem se apropriar dos conhecimentos escolares atingindo o que se espera em cada etapa do processo educativo desde que sejam questionados os padrões de normalidade e de avaliação comumente utilizados pelas escolas e pelas instituições de saúde para determinar a condução dos processos de escolarização.

Palavras-chave: Intervenção Pedagógica. Ensino Fundamental. Processo de Escolarização. Dificuldades de Aprendizagem. Medicalização. 


\section{INTRODUÇÃO}

Num cenário educacional com altos índices de crianças dos primeiros anos do ensino fundamental - e até mesmo da educação infantil - encaminhadas para avaliação médica e/ou psicológica e posterior tratamento medicamentoso, indagamos qual seria a função da escola e da equipe pedagógica em situações de dificuldades nas relações de ensino e de aprendizagem. Tendo como ponto de partida um olhar pedagógico respaldado por conhecimentos complexos, como os psicológicos, apresentamos o relato de um trabalho desenvolvido com alunos que "não aprendiam".

Trata-se de uma experiência ${ }^{20}$ realizada em uma escola pública de um município do interior do Paraná como parte de um projeto de extensão ${ }^{21}$ vinculado à Universidade Estadual de Maringá (UEM). Teve como principal objetivo questionar as tradicionais avaliações pedagógicas, psicológicas e médicas superficiais e descontextualizadas as quais os alunos eram submetidos, bem como desenvolver ações pedagógicas com crianças do ensino fundamental que apresentavam dificuldades em seu processo de escolarização. Nela foram desenvolvidas atividades que permitiram compreender o processo de constituição da história escolar da criança e das dificuldades apontadas pela equipe pedagógica da escola, como subsídio para o planejamento e a intervenção necessários. 0 trabalho foi fundamentado em uma perspectiva crítica da relação entre Educação e Psicologia que não limita o entendimento dos problemas escolares a aspectos psicológicos dos alunos e/ou de seus familiares (PATTO, 1990).

A intervenção ocorreu em uma escola municipal, com alunos de segundo e terceiro anos do ensino fundamental, escolhidos pelas professoras e pela equipe pedagógica por não apresentarem desempenho escolar esperado para sua faixa etária e série.

Destacamos que não se tratava de reforço escolar, como comumente denominado pela escola e pelos pais, pois consideramos que o ensino dos conteúdos escolares compete à instituição e aos docentes. Nossa finalidade era estabelecer novas relações escolares que permitissem às crianças criar vínculos de competência com a escola, a fim de movimentar os processos de ensino e aprendizagem cristalizados. Para tanto, foram planejadas atividades coletivas diferenciadas daquelas da sala de aula que favorecessem a expressão das capacidades individuais. As relações escolares são necessariamente coletivas, por isso, corroboramos com Machado (2004, p.2) quando aponta que "A inclusão se dá quando se devolve ao coletivo aquilo que foi individualizado no corpo do sujeito".

A maioria das crianças foi encaminhada para o grupo com algum diagnóstico psicológico e/ou médico que supostamente comprometia sua aprendizagem, mas ao longo de nossos encontros não foi identificado na criança algo que pudesse explicar as dificuldades descritas pela escola sobre seu processo de escolarização. Verificamos que as questões pedagógicas, específicas do trabalho escolar e da equipe profissional não são consideradas quando a discussão é sobre a não aprendizagem; em seu lugar são apontados problemas psicológicos dos alunos que afetariam a vida escolar. Machado (2004, p.10) pontua que:

A história dessa relação, Psicologia/Educação, tem-nos feito, muitas vezes, preferir o distanciamento dos psicólogos em relação à Educação do que o contrário. Psicólogos compactuam com a exclusão quando trabalham desconsiderando o funcionamento do território no qual a exclusão se engendra, realizando avaliações baseadas em padrões de normalidade criados por testes psicológicos e redigindo relatórios sobre os sujeitos apresentando o que 'falta' na família, o que 'falta' na escola, o que 'falta' nos professores, o que 'falta' nas crianças. Tudo se torna 'falta' e não se percebe o transbordamento que se produz por não caber os sujeitos no funcionamento institucional da maneira como está.

20 O relato de experiência aqui mencionado foi apresentado no evento XII Congresso Nacional de Educação EDUCERE, realizado na Escola de Educação e Humanidades da Pontifícia Universidade Católica do Paraná, no período de 26 a 29 de outubro de 2015, em Curitiba-PR. 0 texto que segue é uma versão revisada e ampliada desse material. 21 Projeto de extensão intitulado Revisitando histórias de escolarização: o trabalho pedagógico com os chamados 'problemas de aprendizagem' para além dos reducionismos psicológicos, coordenado pela Profa. Dra. Aline Frollini Lunardelli, da Universidade Estadual de Maringá (UEM). 
A "falta", no contexto por nós aqui relatado, era atribuída preponderantemente à criança, de tal forma que eram comuns e rotineiras situações de encaminhamento ao médico para que realizasse exames neurológicos e medicasse os supostos problemas detectados. A maioria dos alunos que participou desse trabalho consumia há bastante tempo Metilfenidato ${ }^{22}$. Os padrões estabelecidos pela escola fazem com que a medicalização seja uma forma de atribuir ao aluno a causa do problema, como se aprender fosse uma questão individual. Collares e Moysés (1994) defendem que se trata de um processo necessariamente coletivo, porque é realizado na escola. Logo, as questões institucionais devem ser consideradas.

As autoras assinalam que a Educação, assim como todas as áreas sociais, vem sendo medicalizada em grande velocidade, destacando-se o fracasso escolar e seu reverso, a aprendizagem, como objetos essenciais desse processo, relatados como algo individual, inerente ao aluno, um elemento meio mágico, ao qual o professor não tem acesso, portanto, também não tem responsabilidade. 0 termo medicalização, de acordo com as autoras, refere-se ao processo de transformar questões não-médicas, eminentemente de origem social e política, em questões médicas.

Ao questionar os processos de medicalização, partíamos do pressuposto de que todas as crianças que frequentavam nosso grupo eram capazes de aprender e nos relacionávamos com elas a partir desse princípio norteador que, por si só, já era responsável por gerar movimento nas situações de ensino e aprendizagem estagnadas. Assim, uma criança, por exemplo, que já tinha ouvido diversas vezes de sua professora e de seus colegas que não sabia ler, se recusava em um primeiro momento, a participar de um jogo. Mas, ao ser encorajada a jogar, independentemente das habilidades de leitura, aos poucos, participava das atividades e constatava que sabia fazer muitas coisas, dentre elas, ler, ainda que lhe faltasse o domínio de todos os elementos desse processo. Concordamos com Collares e Moysés (2013, p. 133) quando afirmam:

Não negamos a existência de pessoas que lidam com a linguagem escrita de diferentes maneiras, mais do que possamos imaginar; algumas com mais dificuldades, outras com incrível facilidade, a maioria em um continuum entre esses extremos. 0 que questionamos é a transformação disso em uma pretensa doença neurológica, que jamais foi comprovada e é intensamente criticada no interior do próprio campo médico, muitas vezes tratada somente com intervenção pedagógica.

Nesse território no qual as dificuldades aparecem e onde medicalizar tem sido "a varinha de condão", optamos por construir recursos essencialmente pedagógicos a fim de devolver às crianças sua competência, enfraquecida por sua história escolar.

\section{METODOLOGIA}

Para atingir as finalidades propostas no projeto, foi formado um grupo de doze crianças dos segundos e terceiros anos do ensino fundamental que se reunia semanalmente na escola no contraturno das aulas. Ao longo de um trimestre, foram realizados quinze encontros de duas horas de duração cada, denominados Oficinas Pedagógicas. Era composto por três meninas e nove meninos, com idade entre oito e treze anos. Desse total, oito crianças contavam com histórico de reprovação e uma delas havia reprovado quatro vezes. Vieram de duas salas de aula diferentes, envolvendo, portanto, duas professoras.

As queixas das professoras sobre as crianças diziam respeito a desinteresse em aprender, extrema dificuldade na leitura e escrita, mau comportamento e falta de colaboração em sala de aula. Em alguns casos, situação socioeconômica e dados sobre a condição familiar faziam parte da queixa.

Foram feitas também reuniões com as professoras e com os pais. Com as professoras das turmas visamos identificar os motivos do encaminhamento e, posteriormente, discutir o andamento do processo. Nas reuniões com os pais, pretendíamos investigar como a família compreendia a queixa e de que maneira se relacionava com a escola. Explicávamos os objetivos do projeto e ouvíamos sugestões quanto à maneira

22 Substância estimulante do sistema nervoso central conhecida como Ritalina. 
mais eficaz, na avaliação dos responsáveis, para lidar com situações de resistência das crianças na realização de atividades escolares.

Quanto ao trabalho coletivo com os alunos, as primeiras reuniões foram no intuito de criar vínculo com as pedagogas, conhecê-los, resgatar, por meio de ações planejadas e intencionais, as suas habilidades escolares e destacá-las, além de integrá-las ao grupo almejando outro tipo de comportamento apresentado até então - respeitando os colegas.

Durante os encontros buscávamos tarefas coletivas e de interesse de todos, geralmente com técnicas não convencionais; não era usado caderno como no ensino regular, valendo-se de outros registros, como composição de cartazes, desenhos, pinturas, ilustrações em geral, músicas. A escolha por outros recursos tinha como finalidade mostrar que as crianças podiam produzir materiais escritos de outras formas, o que permitiu intervir na resistência em realizar qualquer tarefa que se parecesse com aquelas feitas em sala de aula.

Escolhemos como tema central Brincadeiras Infantis, por ser atrativo para as crianças, com base no livro As Brincadeiras do Mundinho, de Ingrid Biesemeyer Bellinghausen (2011), o qual aborda atividades coletivas como amarelinha, caracol, batata-quente e caça ao tesouro. A partir delas, pudemos recriar junto com as crianças outras brincadeiras como caça-palavras, palavras cruzadas, confecção de brinquedos e registro das instruções sobre como elaborá-los.

Como principais recursos materiais, utilizamos livros de histórias, literatura infantil e infanto-juvenil, material reciclável, cartolinas, aventais, jogos, tinta, pinceis, jornal, canetinhas, lápis de cor, lápis, cola, tesoura, sulfite branco e colorido, EVA, cola gliter, cola colorida, barbante, giz de cera, lantejoulas, envelopes de papel, papel craft, papel crepom, papel cartão, bambolê, bola, corda, fotos; todos de fácil acesso e disponíveis na maioria das escolas.

Foram confeccionados, por exemplo, binóculos com rolinhos de papel higiênico; as crianças produziram um cartaz, contendo instruções sobre quais materiais são necessários para fazer o brinquedo e um 'modo de fazer', com os passos a serem seguidos. Escreveram o cartaz, detalharam os passos e os materiais utilizados, de tal forma que a confecção do binóculo foi o ponto de partida para a produção de diferentes tipos de registro, inclusive escrito, tão rejeitado pelos alunos no início dos trabalhos.

Todos os brinquedos foram expostos num evento organizado na escola em momento posterior, no qual puderam ensinar a outros alunos e a suas professoras como confeccioná-los. A exposição foi acompanhada pela equipe pedagógica e docentes, que puderam constatar que aquelas crianças a nós encaminhadas porque não aprendiam - eram capazes de ensinar!

Também foram desenvolvidos dois projetos com fotografias: no primeiro deles, as crianças criaram um álbum com as fotos tiradas no decorrer dos encontros que mostravam suas produções; no outro, escolhiam um local da escola que lhes agradava para registrar, por meio da técnica Pinhole ${ }^{23}$, "Foto na Lata", permitindo discutir o que se faz e como se vive dentro da instituição.

\subsection{PROCESSO GRUPAL}

0 desenvolvimento do trabalho permitiu problematizar as formas tradicionais de avaliar alunos que, supostamente, apresentam dificuldades para aprender. Proporcionou, ainda, às crianças identificar suas competências e habilidades e, mais do que isso, estabelecer novas relações de aprendizagem e de convivência com seus colegas e professores.

No que se refere especificamente ao grupo de alunos, verificou-se que, no início, as crianças mostravam-se tímidas, retraídas, desinteressadas e resistiam às atividades, já que vivenciaram várias reprovações e

23 Pinhole é um processo alternativo de fazer fotografia utilizando materiais simples. Consiste em uma lata de alumínio, pintada de preto e com um papel fotográfico por dentro, com um furo no meio e com um adesivo "abre e fecha", que permite a entrada da luz que fará com que se registre a imagem. 
avaliações negativas por parte dos docentes e também dos profissionais da saúde. Colegas e professores os consideravam como os que "atrapalhavam a aula", "loucos", "com problema de cabeça", "não sabe fazer nada", "não sabe ler e escrever", visão estereotipada construída a partir de práticas também estereotipadas de ensino e aprendizagem.

Nas atividades planejadas, notamos que todas as crianças leram e escreveram com certa autonomia, ainda que, inicialmente, tenham dito enfaticamente que não sabiam realizar tais tarefas. Com mediação das pedagogas e dos colegas produziram diversas formas de registros escritos. Vale destacar que, no contexto de sala de aula, essas mesmas habilidades não foram detectadas por suas professoras. A situação coletiva, de valorização de todas as produções, com propostas diferentes daquelas desenvolvidas em sala, pode ter favorecido seu aparecimento. Aos poucos, as resistências foram vencidas e os próprios alunos perceberam que dominavam muitos conteúdos e capacidades específicas da vida escolar.

Na exposição das Brincadeiras Infantis - evento que possibilitou aos alunos ocupar o lugar do saber na escola - houve um grande envolvimento de todos, principalmente porque ensinariam as demais crianças e suas professoras, mostrando que podem coordenar atividades e interagir com outras pessoas. Em cada grupo era possível notar que as crianças explicavam detalhadamente aos visitantes como fazer brinquedos, caça-palavras e palavras-cruzadas. Um mural com as fotos das crianças e de suas produções foi colocado no local para que todos conhecessem o processo de preparação do evento.

A exposição tinha como finalidade oferecer aos alunos que participaram do projeto um lugar de protagonismo, muito diferente daquele que ocupavam em sala de aula e nas clínicas médicas. Ao invés de incapazes, desatentos, mal comportados, inquietos, tínhamos crianças concentradas, atentas, organizadas, criativas, motivadas que vivenciaram situações bastante sofisticadas, do ponto de vista cognitivo, ao ensinar seus amigos e suas professoras a fazer tarefas que não sabiam. Com isso, pudemos, ainda que de forma circunscrita, refletir sobre os rótulos imprimidos naquelas crianças e, certamente, após aquela experiência, suas professoras passaram a questionar a incapacidade anteriormente detectada, conforme relatado por elas em reunião pedagógica posterior.

Não identificamos nas crianças nenhum fator que as impeça de se desenvolver no contexto escolar. Aquelas que se retraíam no início e mostravam-se tímidas, tornaram-se ativas e falantes, realizando o que era proposto. Faziam questão de nos contar o que desenvolviam em sala de aula, em casa, nos finais de semana, com os amigos e apresentavam sugestões para o funcionamento de nossas intervenções.

Nos encontros grupais, as crianças escreviam, liam, contavam histórias, desenhavam, pintavam, desvendavam enigmas, executavam operações matemáticas, detectavam suas dificuldades e procuravam ajuda para solucioná-las, ouviam pacientemente um colega que se aventurava na tentativa de ler um recado, um bilhete ou uma história.

Yara ${ }^{24}, 13$ anos, com duas reprovações no segundo ano e uma no terceiro, a princípio, disse que não sabia ler e escrever, e mostrava-se tímida nos primeiros encontros. Afirmava que "devia ter algum problema na cabeça" que não a deixava fazer as atividades. Na realização de um caça ao tesouro, por exemplo, havia enigmas a serem desvendados para que o grupo encontrasse o baú. Ao ser solicitada a participar da tarefa coletiva, ela leu em voz alta o que os colegas deveriam fazer.

Concordamos com Tanamachi e Meira (2003) quando defendem que o processo de humanização da criança dá-se através da apropriação dos conceitos científicos, por meio da linguagem, consciência e emoções, e esse processo se realiza de maneira intencional e sistematizada na escola, lugar privilegiado para que tais conceitos se formem. Se a relação com a vida escolar vai mal, é necessário que seja resgatada, por isso nosso intuito era investigar o caminho percorrido pela criança durante sua história de escolarização que a levou a ocupar o lugar de incapaz a fim de movimentar relações pedagógicas cristalizadas, de tal modo que diversas atividades coletivas foram propostas e desenvolvidas pelo grupo. Destacamos nesse relato o caça-palavras das brincadeiras infantis, que continha nomes de brincadeiras

${ }^{24}$ Os nomes aqui apresentados são fictícios para preservar a identidade dos participantes. 
para serem descobertos. Reunidas em pequenos grupos, as crianças deveriam executar a tarefa proposta. Nenhum caça-palavras era igual ao outro, mas possuíam os mesmos nomes a serem encontrados. Yara, mais uma vez, mostrou-se aflita, dizendo "eu sou burra, não vou conseguir" ou "eu não sei ler, não vou encontrar as palavras". O que fizemos foi afirmar que ela sabia, e que era capaz, diferente do que pensava. Ela foi a aluna que mais se destacou na atividade e quando terminou seu caça-palavras, foi ajudar os colegas. Ao invés de dar a resposta, ela dava dicas sobre como encontrá-la.

Outro momento que merece destaque ocorreu na biblioteca da escola, no qual as crianças poderiam escolher um livro, folheá-lo, lê-lo. Henrique, que dizia "eu não sei ler", "eu não gosto de ler", escolheu um livro de ciências que falava sobre animais e começou a ler. Enquanto lia, enfatizava o tom de voz para as coisas que achava interessante e, assim, seus colegas Arthur, Enzo e Pedro sentiram-se curiosos e fizeram o mesmo.

Mariana, no início do projeto, afirmava frequentemente "eu sou burra, eu não sei ler ainda", e negava-se a participar de tarefas que envolvessem leitura, isolando-se do grupo. 0 que fizemos foi mostrar a ela que o ato de ler é prazeroso e que pode ser feito sem cobranças, sem afirmações negativas. Assim, em um dos momentos de comemoração após o término de uma atividade, presenteamos o grupo com um livro de histórias infantis e um lápis enfeitado. Enzo pediu para que uma das estagiárias lesse a história para ele, enquanto Mariana, disse "eu não quero que ninguém leia para mim, já sei ler sozinha", sentou-se e deu início a sua leitura.

Marcos apresentou uma resistência muito grande no início dos encontros, não participava, atrapalhava os colegas enquanto produziam e não realizava o que era proposto. Após perceber que as atividades eram diferentes daquelas solicitadas pela professora em sala de aula, mas que não possuíam nada de "estranho" àquilo que já sabia, e depois de deixarmos bem claro que os encontros não eram de reforço, ele começou a interagir mais com os colegas e a participar, assim pudemos ressaltar que ele sabia ler e escrever como os demais e poderia fazer o mesmo quando sua professora solicitasse.

Acreditamos que todas as crianças que participaram do projeto têm total condição de se desenvolver com êxito, apesar de um histórico escolar marcado por momentos difíceis. Consideramos que não há qualquer fator psíquico ou físico que comprometa sua aprendizagem; demonstram interesse nas atividades e competência para realizar o que é proposto, ao contrário do diagnóstico inicial que nos foi apresentado.

Ao observar a produção das crianças ao final do trabalho de um trimestre do grupo, avaliamos que nossas finalidades foram alcançadas: não ensinamos os conteúdos curriculares de suas séries, tampouco mostramos a elas outras formas de aprender, apenas enfatizamos e potencializamos aquilo que já sabiam e havia sido ensinado por suas professoras, valorizando o máximo de suas capacidades. Produzindo recursos pedagógicos apropriados ao desenvolvimento infantil, partindo do pressuposto de que todos, sem exceção, eram capazes de aprender, independente de seu histórico escolar, propusemos a reconstrução de suas relações com os colegas e professores, a fim de movimentar processos de ensino e aprendizagem paralisados, para que ocupassem outro lugar na escola - um lugar de saberes.

Com relação aos professores, percebemos que valorizaram o trabalho do projeto, pois abriram espaço para uma nova visão sobre as crianças encaminhadas. Porém, não conseguimos efetivar outras ações, como acompanhar mais de perto seu trabalho em sala, para analisarmos conjuntamente posteriores intervenções. Notamos que os docentes ocupam-se de cada aluno individualmente, sem considerar as relações escolares como envolvidas na produção do não aprender. A cada ano fazem uma nova lista dos que "não aprendem", mantendo um ciclo vicioso.

Quanto aos pais, analisamos que estavam mais seguros ao final do projeto com relação ao desempenho de seus filhos, pois, como nós, perceberam mudanças tanto na aprendizagem, quanto no comportamento e interesse pela escola. Demonstraram desejo de sugerir às professoras que adotassem propostas semelhantes as que desenvolvemos. Alguns ressaltaram que a medicação pode não ser o fator decisivo para a aprendizagem de seu filho. 


\section{CONSIDERAÇÕES FINAIS}

As experiências nos espaços escolares têm-nos apresentado, muitas vezes, a produção de relações estereotipadas nas quais alunos e professores são destituídos de suas principais funções. Nesse contexto, é recorrente o encaminhamento - para atividades de reforço, apoio pedagógico, acompanhamento médico e psicológico - daqueles alunos que não correspondem às expectativas da equipe pedagógica e dos docentes no que se refere à aprendizagem de certos conteúdos escolares e aos padrões comportamentais por eles definidos.

O próprio padrão, em si, já seria motivo de questionamento. No entanto, mais do que identificar os entraves nos processos de escolarização que impedem o desenvolvimento principalmente dos alunos, no projeto aqui relatado buscamos averiguar quais formas pedagógicas de avaliação e intervenção podem movimentar espaços cristalizados, a fim de oferecer subsídios para a construção de novas relações entre alunos, pais e professores. Privilegiamos o fortalecimento das crianças, extremamente vulneráveis e prejudicadas por diversas formas de exclusão. 0 trabalho mais de perto junto aos professores seria imprescindível para atingir nossas finalidades, mas, ainda há muito a avançar nesse sentido.

Ressaltamos, no que diz respeito às crianças marcadas por reprovações, estigmatização, avaliações psicológicas e médicas bastante equivocadas, que o trabalho coletivo de reconstrução de suas histórias escolares pode ser um caminho importante para resgatar suas competências, confiança e valorização de suas capacidades.

Retirar um aluno de sala de aula, aplicar exercícios de sua rotina escolar, solicitar que registre palavras, frases, textos, operações matemáticas não só é ineficaz para saber sobre sua experiência escolar, como contribui para paralisar sua aprendizagem. Nessas situações é certa a constatação de que essa criança não sabe muitas coisas que deveria saber.

Contrariando as avaliações pedagógicas, médicas e psicológicas a que foram submetidas, as mesmas crianças que outrora se mostravam incapazes de ler e escrever, por exemplo, ensinam colegas a produzir brinquedos e, para isso, necessariamente, escrevem instruções com as etapas de construção dos materiais. Fizemos uma nova avaliação mais detalhada e contextualizada, para analisar aspectos da vida escolar como um todo, privilegiando as questões pedagógicas, que competem aos professores. Para isso, criamos recursos também pedagógicos apropriados a esse grupo de crianças, após conhecer mais de perto sua realidade, que permitiram avaliar e intervir simultaneamente.

Não ensinamos as crianças a ler, escrever ou realizar operações matemáticas; essa era a tarefa de seus professores. Ainda que os próprios alunos compartilhassem da visão estereotipada sobre suas supostas dificuldades, perceberam ao longo do processo que eram extremamente competentes e já dominavam muitas habilidades e conteúdos escolares. Nossa principal intervenção consistiu na desmistificação do "não saber" e, para isso, propusemos atividades que devolvessem aos alunos um lugar de competência e protagonismo. Concordamos com Martins (2009), quando aponta que o papel da educação não pode ser simplificado, pelo contrário, deve mostrar o máximo que puder para promover o desenvolvimento humano, caso isso não ocorra, será mínimo no cumprimento de sua tarefa.

Sugerimos ao final desse processo que, antes de identificar problemas nas crianças que possam comprometer seu desenvolvimento, professores resgatem suas funções pedagógicas, elaborando e discutindo formas de avaliar e intervir compatíveis com sua realidade escolar.

\section{REFERÊNCIAS}

[1] Bellinghausen, Ingrid Biesemeyer. As brincadeiras do mundinho. 1. ed. Editora Canoa, 2011.

[2] Collares, Cecília Azevedo Lima; MOYSÉS, Maria Aparecida Affonso. A transformação do espaço pedagógico em espaço clínico: a patologização da educação. 1994. p. 25- 31. Disponível em: <www.crmariocovas.sp.gov.br.> Acesso em: jun. 2015.

[3] _. O lado escuro da dislexia e do tdah. In: Facci, Marilda Gonçalves Dias; Meira, Marisa Eugênia Melillo (Orgs.). A exclusão dos incluídos. 2. ed. Maringá: Eduem, 2013, v. 1, p. 133-195. 
[4] Machado, Adriana Marcondes. Educação inclusiva: de quem e de quais práticas estamos falando? In Reunião Anual da Associação Nacional de Pós-Graduação e Pesquisa em Educação - Sociedade, Democracia e Educação: Qual Universidade?, 27, 2004, Caxambu. Sessões especiais/debates, Anais. Caxambu, 2004, p.1-14. Disponível em: < http://27reuniao.anped.org.br/diversos/se_adriana_marcondes_machado.pdf $>$. Acesso em: jun. 2015.

[5] Martins, Ligia Márcia. 0 ensino e o desenvolvimento da criança de zero a três anos.

[6] In: Arce, Alessanda; Martins, Lígia Márcia (Orgs). Ensinando aos pequenos de zero a três anos. Campinas: Editora Alínea, 2009, p.94-121.

[7] Patto, Maria Helena Souza. A produção do fracasso escolar: histórias de submissão e rebeldia. São Paulo: T. A. Queiroz, 1990.

[8] Tanamachi, Elenita de Ricio; Meira, Marisa Eugênia Melillo. A atuação do psicólogo como expressão do pensamento crítico em Psicologia e Educação. In: MEIRA, Marisa Eugênia Mellilo; Antunes, Mitsuko Aparecida Makino (Orgs.). Psicologia Escolar: Práticas Críticas. 1. ed. São Paulo: Casa do Psicólogo, 2003. p. 11-62 


\section{Capítulo 11}

\section{Considerações acerca da I Mostra de Surdez e Educação do IFMA Campus Viana - Ma}

\section{Erika Patrícia Martins Ferreira \\ Maria do Socorro de Sousa \\ Maycon Cesar Pereira Wernz. \\ Claudia de Oliveira Vale \\ Jodelma Castelo Branco Mendes \\ Sephora Santana Souza \\ Aline Antonia Santos Lins}

Resumo: Este trabalho é reflexo da Semana Nacional da Pessoa com Deficiência desenvolvido anualmente como um projeto de extensão pelo Instituto Federal de Educação, Ciência e Tecnologia do Maranhão (IFMA), Campus Viana, que resultou na I MOSTRA SURDEZ E EDUCAÇÃO NA ESCOLA: UM OLHAR SOBRE A INCLUSÃO SURDO, pelo Núcleo de Atendimento às Pessoas com Necessidades Educacionais Específicas (NAPNE) em parceria com a rede Municipal de Educação de Viana-MA e o Centro de Referência a Assistência Social (CRAS). A repercussão deste trabalho se deu com vistas a sensibilizar e capacitar a comunidade escolar ao exercício da inclusão cidadã da pessoa com surdez. Este trabalho culminou na realização de oficinas de libras, palestra educativa de prevenção à surdez, formação continuada aos gestores e professores e pais da rede Municipal do Ensino de Viana - MA. Os resultados foram obtidos em consonância com a resolução № 015 de 27 de fevereiro de 2015 do NAPNE, com vistas à promoção cultural da "Educação para a convivência", aceitação da diversidade, principalmente, promoção da quebra de barreiras e capacitação da comunidade escolar de forma a convergir a inclusão de todos(as) na educação profissional e tecnológica.

Palavras chave: Políticas Públicas; IFMA, Inclusão Cidadã; Práticas Pedagógicas; Educação de surdos. 


\section{INTRODUÇÃO}

A Educação Especial está presente em todos os níveis, etapas e modalidades de ensino proporcionando aos seus alunos serviços, recursos e estratégias de acessibilidade ao ambiente e aos conhecimentos escolares. Nesse contexto, deixa de ser um sistema paralelo de ensino, com níveis e etapas próprias e se torna uma ação inclusiva.

A Lei de Diretrizes e Bases da Educação 9.394/1996 representa um avanço ao assegurar em seu capítulo $\mathrm{V}$, o atendimento aos alunos com necessidades educacionais especiais "preferencialmente na rede regular de ensino" e ao destacar um capítulo para a Educação Especial, inserindo-a no contexto das discussões sobre Educação e Políticas Públicas. (BRASIL, 1996). Com isso sinaliza-se uma nova concepção de Educação Especial, onde a Política enseja novas práticas de ensino, com vistas a atender as necessidades dos alunos que constituem seu público alvo, garantindo-lhes o direito à educação.

o grande objetivo desse novo modelo de educação é redirecionar os caminhos até então trilhados, subvertendo a hegemonia de uma cultura escolar segregadora, buscando possibilidades e oportunidades de se reinventar princípios e práticas cada vez mais inclusivas.

Vale lembrar que espaços escolares inclusivos são fundamentados em uma concepção de identidade e diferenças, em que as relações entre ambas não se ordenam em torno de oposições binárias (normal/especial, branco/negro, masculino/feminino, pobre/rico) Neles não se elege uma identidade como norma privilegiada em relação às demais.

Percebe-se diante do exposto, que a Educação dentro de um amplo painel, onde pessoas com perfil próprio, com suas peculiaridades, precisam estar juntas de forma igualitária dispondo-se a conviver e extrair desse processo o melhor resultado possível, pois segundo Vygotsky (1998) a interação é necessária para a aprendizagem da linguagem e desenvolvimento humano nos seus diferentes aspectos: cultural, cognitivo, emocional e social. Sendo assim, o espaço escolar precisa ser um espaço onde os aprendizes tenham e sintam liberdade para se expressar em uma ou outra língua que no caso do surdo do Brasil será sua L1 correspondendo a sua língua materna de sinais e a L2 que é a língua do país onde ele reside.

Para isso, a escola precisa ser militante na luta pela eliminação das barreiras existentes em seu interior de modo a promover a inclusão e o exercício da cidadania preparando os sujeitos para a convivência em sociedade de forma autônoma, respeitosa, desconstruindo preconceitos que refletem a crença de que os seres são igualmente dotados de uma única capacidade que é a capacidade de aprender e junto a isso a escola precisa fortalecer sua missão possibilitando práticas pedagógicas pautadas nos pilares educacionais: aprender a ser, a fazer, a conhecer e a conviver.

O IFMA, ciente da sua responsabilidade enquanto instituição educativa, busca atender a estas necessidades e cumprir sua missão institucional de "Promover educação profissional científica e tecnológica comprometida com a formação cidadã para o desenvolvimento sustentável" (IFMA, 2015). Assim, o Projeto Pedagógico Institucional (PPI) do IFMA recomenda:

Nesse cenário impõe-se a discussão sobre uma educação inclusiva, admitida como cultura coletiva. Essa postura permite ao sujeito a possibilidade de assumir suas identidades, e de respeitar as possibilidades do outro. Desta forma, a educação formal precisa reconhecer a multiplicidade de identidades, e essa multiplicidade precisa ser incorporada e vivenciada no currículo escolar. (IFMA, 2016, p. 12)

Neste sentido, o Núcleo de Atendimento às Pessoas com Necessidades Específicas (NAPNE) do Instituto Federal do Maranhão (IFMA) campus Viana vem relembrar as lutas e vitórias vivenciadas pelos surdos no seu percurso histórico, como meio de homenagear a comunidade surda no dia 26 de setembro, Dia Nacional do Surdo que tem como marco o surgimento em 1857 do primeiro Instituto de Educação para Surdos no Brasil, o Instituto Nacional de Educação de Surdos (INES) situado no Rio de Janeiro. Para tanto, com a I MOSTRA SURDEZ E EDUCAÇÃO NA ESCOLA: UM OLHAR SOBRE A INCLUSÃO SURDO que foi realizada na Unidade Escolar Estevam Carvalho no período de 11 a 27 de setembro de 2017, trata-se deum marco introdutório de implementações inclusivas para pessoas com surdez na região da Baixada Maranhense, de modo mais específico, no município de Viana -MA.

Pretendeu-se por meio de diversas atividades dentre elas palestras, oficinas, apresentações artísticas, exposições, e filmes levar o corpo docente, discente daquela escola bem como do IFMA e da comunidade surda do município de Viana conhecer um pouco da história do povo surdo e despertar a consciência de que estes falantes da LIBRAS possuem uma cultura, compreendem e interagem com o meio de forma 
visual através de sua língua e assim têm necessidades específicas de um olhar subjetivo na sua inserção no meio educacional.

\section{FUNDAMENTAÇÃO TEÓRICA}

O processo de Inclusão e Acessibilidade é um direito de todos os seres humanos e isso é incontestável perante a materialização das leis vigentes acerca da garantia do direito a equidade. A Inclusão é uma forma que nos conecta com o mundo, e sua cultura. A educação inclusiva segundo a Política Nacional de Educação Especial na perspectiva da Educação Inclusiva deve acompanhar "[...] os avanços do conhecimento e das lutas sociais, visando constituir políticas públicas promotoras de uma educação de qualidade para todos os estudantes". (BRASIL, 2008, p.1)

Nesse sentido, é impossível dissociar os conceitos fundamentais de acessibilidade e de inclusão quando se deseja discutir a participação de todos. Isto porque, por estarem intimamente relacionados, tais conceitos necessitam não somente de uma mudança de paradigma, mas também de uma desconstrução das práticas excludentes até então utilizadas, bem como de uma reflexão sobre o que emana das novas relações e de suas múltiplas e enriquecedoras diferenças. A educação inclusiva constitui-se um direito da pessoa com deficiência, no sistema educacional inclusivo em todos os níveis, com intuito de alcançar o nível superior de progresso possível de seus talentos e habilidades físicas, sensoriais, intelectuais e sociais, segundo sua singularidade (LBI.2015). Convergente a essa corrente, a Lei Brasileira de Inclusão (2015) ressalta em seu artigo 28:

I - sistema educacional inclusivo em todos os níveis e modalidades, bem como o aprendizado ao longo de toda a vida;

II - aprimoramento dos sistemas educacionais, visando a garantir condições de acesso, permanência, participação eaprendizagem, por meio da oferta de serviços e de recursos de acessibilidade que eliminem as barreiras e promovam a inclusão plena;

III - projeto pedagógico que institucionalize o atendimento educacional especializado, assim como os demais serviços e adaptações razoáveis, para atender às características dos estudantes com deficiência e garantir o seu pleno acesso ao currículo em condições de igualdade, promovendo a conquista e o exercício de sua autonomia;

IV - oferta de educação bilíngue, em Libras como primeira língua e na modalidade escrita da língua portuguesa como segunda língua, em escolas e classes bilíngues e em escolas inclusivas;

V - adoção de medidas individualizadas e coletivas em ambientes que maximizem o desenvolvimento acadêmico e social dos estudantes com deficiência, favorecendo o acesso, a permanência, a participação e a aprendizagem em instituições de ensino;

VI - pesquisas voltadas para o desenvolvimento de novos métodos e técnicas pedagógicas, de materiais didáticos, de equipamentos e de recursos de tecnologia assistiva;

VII - planejamento de estudo de caso, de elaboração de plano de atendimento educacional especializado, de organização de recursos e serviços de acessibilidade e de disponibilização e usabilidade pedagógica de recursos de tecnologia assistiva;

VIII - participação dos estudantes com deficiência e de suas famílias nas diversas instâncias de atuação da comunidade escolar. (BRASIL, 2015, p.6-7)

Percebe-se diante do exposto, que a Educação dentro de um amplo painel, onde pessoas com perfil próprio, com suas peculiaridades, precisam estar juntas de forma igualitária dispondo-se a conviver e extrair desse processo o melhor resultado possível, pois segundo Vygotsky (1998) "É na troca com outros sujeitos que o conhecimento e as funções sociais são assimilados". Portanto, o ambiente escolar precisa ser um espaço onde os aprendizes tenham e sintam liberdade para se expressar em uma ou outra língua (L1 e L2). Para isso, a escola precisa garantir esses espaços de troca de conhecimento, assim como investir na formação de professores e profissionais da educação, pois somente assim, com um espaço de amplo 
acolhimento e de pessoas bem informadas poderemos propiciar uma educação cada vez mais inclusiva onde todos os sujeitos têm voz e seus espaços garantidos no ambiente escolar e por conseguinte têm também consciência e entendimento dos seus direitos e deveres dentro da sociedade, contribuindo assim para a promoção de uma educação igualitária.

Alves (2010) assevera que:

[...] o embate epistemológico entre o uso exclusivo da Libras ou o uso exclusivo do Língua Portuguesa, além de questões levantadas sobre o bilinguismo, é manter a exclusão escolar dos alunos com surdez. Assim, deflagrar iniciativas no meio escolar pautadas no reconhecimento e na valorização das diferenças, que demonstram a possibilidade da educação escolar inclusiva de pessoas com surdez na escola comum brasileira (ALVES, 2010, p. 8)

No que concerne a participação do educador no contexto da relação humana Saviani (1995, p. 17) cita:

"[... o trabalho educativo é o ato de produzir direta e intencionalmente, em cada indivíduo singular, a humanidade que é produzida histórica e coletivamente pelo conjunto dos homens". Assim o objetivo da educação diz respeito, de um lado, à identificação dos elementos culturais que precisam ser assimilados pelos indivíduos da espécie humana para que eles se tornem humanos e, de outro lado e concomitantemente, à descoberta das formas mais adequadas para atingir esse objetivo.

Logo, a inclusão, nesse contexto, evidencia um compromisso da escola ao assumir a educação de cada criança. Assim, a proposta de inclusão é contemplar a pedagogia da diversidade, ou seja, todos os alunos deverão estar dentro da escola regular, independentemente de suas especificidades.

Este paradigma educacional inclusivo propiciou o surgimento de novas leis, como a lei no 12.319 , de 1o de setembro de 2010, que insere o profissional tradutor e intérprete de língua de sinais em sala de aula, com intuito de, garantir ao surdo a aquisição dos conteúdos escolares em sua própria língua.

A LIBRAS que foi oficializada no Brasil pela Lei no 10.436, de 24 de abril de 2002 (BRASIL, 2002, p.01) explicita em seu Artigo 1을

É reconhecida como meio legal de comunicação e expressão a Língua Brasileira de Sinais - Libras e outros recursos de expressão a ela associados. Parágrafo único. Entende-se como Língua Brasileira de Sinais - Libras a forma de comunicação e expressão, em que o sistema linguístico de natureza visualmotora, com estrutura gramatical própria, constituem um sistema linguístico de transmissão de ideias e fatos, oriundos de comunidades de pessoas surdas do Brasil.

A LIBRAS como qualquer outra língua apresenta-se com estrutura própria contemplando os níveis fonológico, morfológico, sintático semântico e pragmático o que a torna uma língua de expressão do povo surdo. Observa-se que só após três anos em 2005, foi editado o Decreto Federal no 5.626 (BRASIL, 2005, p.03), em 22 de dezembro que regulamenta a LIBRAS, em seu capítulo IV infere:

Art. 14. As instituições federais de ensino devem garantir, obrigatoriamente, às pessoas surdas acesso à comunicação, à informação e à educação nos processos seletivos, nas atividades e nos conteúdos curriculares desenvolvidos em todos os níveis, etapas e modalidades de educação, desde a educação infantil até à superior.

O Decreto além de normatizar a LIBRAS insere a obrigatoriedade do intérprete de Libras nos ensinos fundamental, médio e superior. A difusão da LIBRAS como língua oficial das comunidades surdas do Brasil gerou mudanças significativas para o ensino-aprendizado dessas pessoas.

Ressalta-se que anterior, a regulamentação da Libras, os surdos só poderiam ingressar aos estudos pelo método oral, o qual consistia no acesso à língua falada, da ampliação do som e na expressão por meio da fala (PEREIRA, 2013). A escolha do método oral como única forma possível de educar o surdo aconteceu em 1880 em Milão na Itália no II Congresso Internacional de Educação do Surdo. Nesse evento ficou decidido "a proibição à língua de sinais nas escolas para surdos". Logo, nestas condições, somente os surdos oralizados poderiam prosseguir nos estudos e, ainda, com dificuldade: 0 reflexo da "proibição do uso da língua de sinais na educação de surdos por volta de mais de cem anos trouxe como consequência 
baixo rendimento escolar e a impossibilidade de o surdo prosseguir seus estudos em nível médio e superior." (PEREIRA, 2013, p. 11)

Com a regulamentação da Lei de Libras pelo Decreto no 5.626 de 22 de dezembro 2005, a educação começa a ser mais acessível a toda a comunidade surda no meio educacional; surdos oralizados, deficientes auditivos ou usuários da língua de sinais tiveram seus direitos educacionais garantidos. " 0 oralismo puro aos poucos perdeu sua importância e a tolerância para com os surdos que desejam a língua de sinais e a diferença se faz presente." (PERLIN, 2012, p. 3). A partir das mobilizações dos movimentos surdos e da publicação e divulgação das leis de acessibilidade e da Libras, muitas condutas vão se modificando com intuito da garantia do acesso e permanência desses educandos.

Portanto, buscando alcançar o objetivo estabelecido no Plano de Desenvolvimento Institucional (PDI) do IFMA, referente à política descentralizada de eventos, cursos e projetos de extensão, no sentido de contribuir para o desenvolvimento socioeconômico dos municípios no entorno do IFMA, (PDI, IFMA 20142018) o Campus Viana busca cumprir, através deste projeto, a meta de elevar a taxa de indivíduos da comunidade atingidos alcançados por projetos de extensão que visam favorecer e estimular a sensibilização e mobilização da sociedade para a eliminação de barreiras atitudinais uma ação pro-ativa em direção à construção de uma sociedade inclusiva solidária, que possibilite igualdade e oportunidade e a transformação do homem e da sociedade.

É uma das atribuições da Educação Profissional advindas com a criação da Rede Federal de, Educação Profissional e Tecnológica (Lei № 11.892, de 29 de dezembro de 2008):

0 respeito à diversidade humana e a desconstrução dos preconceitos e discriminações que levam à violação dos direitos, constituem-se em princípios norteadores do processo educativo que visa à preparação da pessoa para uma convivência democrática, equânime, justa e promotora da cultura de paz. (PPI IFMA, 2016, p. 12)

Ademais, no incentivo da busca em alcançar uma das finalidades do NAPNE que é promover o acesso, a permanência e a conclusão dos cursos pelos estudantes do IFMA, na perspectiva da inclusão social e democratização do ensino, conforme preconiza os artigos 205 e 206 da CF/88 e o art. 3o da Lei de no 9.394/96. Entende-se ainda que as escolas devem almejar a consolidação de práticas inclusivas que as tornem uma referência na implementação a busca do direto de todos.

\section{REFERÊNCIAS}

[1] Brasil. Decreto no 5.626, de 22 de dezembro de 2005. Regulamenta a Lei no 10.436, de 24 de abril de 2002 . Dispõe sobre a Língua Brasileira de Sinais - Libras, e o art. 18 da Lei no 10.098, de 19 de dezembro de 2000.

[2] __. Lei n $\mathrm{n}^{\circ}$ 9. 394, de 20 de dezembro de 1996. Estabelece as diretrizes e bases da educação nacional. Disponível em: < http://www.planalto.gov.br/ccivil_03/leis/2002/L10436.htm>. Acesso em: 26 fev. 2016.

[3] _. Lei $\mathrm{n}^{\circ} 10.098$ de 19 de dezembro de 2000. Estabelece normas gerais e critérios básicos para a promoção da acessibilidade das pessoas portadoras de deficiência ou com mobilidade reduzida, e dá outras providências. Disponível em: http://www.planalto.gov.br/ccivil_03/leis/L10098.htm. Acesso em: 26 set. 2016.

[4] _. Lei $\mathrm{n}^{\circ}$ 10. 436, de 24 de abril de 2002. Dispõe sobre a Língua Brasileira de Sinais - Libras e dá outras providências. Disponível em: < http://www.planalto.gov.br/ccivil_03/leis/2002/L10436.htm>. Acesso em: 26 fev. 2016.

[5] _. Lei $\mathrm{n}^{\circ}$ 13.146, de 06 de julho de 2015. Institui a Lei Brasileira de Inclusão da Pessoa com Deficiência (Estatuto da Pessoa com Deficiência). Disponível em: < http://www.planalto.gov.br/ccivil_03/_ato2015-2018/2015/lei/l13146.htm>. Acesso em: 26 fev. 2016.

[6] _. Lei $\mathrm{n}^{\circ} 12.319$ de 01 de dezembro de 2010. 436, de 20 de dezembro de 1996. Regulamenta a profissão de Tradutor e Intérprete da Língua Brasileira de Sinais - Libras. Disponível em: < http://www.planalto.gov.br/ccivil_03/leis/2002/L10436.htm>. Acesso em: 26 fev. 2016.

[7] Ifma. Projeto Pedagógico Institucional: uma construção de todos. Disponível em https://portal.ifma.edu.br/home/>. Acesso em: 14.06. 2019.

[8] Pereira, Maria Cristina da Cunha. (Org.). Libras: conhecimento além dos sinais. São Paulo: Pearson Prentice Hall, 2013.

[9] Perlin, Gladis. Surdos: cultura e transformação contemporânea. In: Perlin, Gladis; Stumpf, Marianne. (Org.), Um olhar sobre nós surdos. Curitiba: CRV, 2012.

[10] Saviani, D. Escola e democracia. 21a ed. São Paulo, Cortez e Autores Associados, 1989.

[11] Vigotski, L.S.A. Formação social da mente.6ed.São Paulo: Martins Fontes,1998. 


\section{Capítulo 12}

\section{Singularidade surda mesmo quando a fonoaudiologia não quer e a educação não entende!...}

\section{Silvana Elisa de Morais Schubert}

Ronaldo Quirino da Silva

Jefferson Diego de Jesus

Luiz André Brito Coelho

Marcelo Elisio Vasicki

Resumo: 0 texto analisa as dificuldades percorridas pelos surdos na educação. Trata das interferências da fonoaudiologia no ensino de surdos, da aceitação pacífica dos professores frente às imposições clínicas principalmente da fonoaudiologia. Destaca a questão do implante coclear enquanto tecnologia que pode (ou não) auxiliar o surdo na capacidade de ouvir, mas que não pode ser substitutiva a língua de sinais regulamentada pelo Decreto 5626/05, o qual estabelece o direito do estudante surdo a ter ensino por meio da língua de sinais e adverte que as crianças surdas devem ser inseridas precocemente na educação bilíngue, mas, traz a contradição quando dá aos pais o direito de optar por um ensino sem o uso da Libras. Entendemos que isso não contribui para o sucesso de uma educação bilíngue, e não oferece oportunidade de desenvolver uma identidade segura e saudável para a criança surda, já que as pesquisas apontam que entre 90 a 95\% dos nascidos surdos, são de famílias ouvintes, portanto não há identificação primeira dos pais com os filhos, motivo que desperta um intenso desejo de corrigir a falta. A família pode ser o primeiro modelo de exclusão ainda que não seja intencional (uma exclusão na busca de incluir, ou seja; uma contradição). Quanto às crianças surdas que passaram pelo implante coclear, denunciamos as interferências clínicas no modelo educacional e a falta de interações por meio de uma educação bilíngue, esclarecendo que mesmo diante de imposições da aprendizagem oral, ao retirar o aparelho essa criança é uma pessoa surda e deve ser reconhecida como tal. Trazemos ao debate fragmentos de entrevistas e questionários com fonoaudiólogos, analisamos as relações com: a educação, professores e surdos que merecem ser refletidas. Um convite até mesmo aqueles que não conhecem a respeito dos surdos.

Palavras-chave: Surdos. Surdez. Educação. Singularidade surda. Implante Coclear. 


\section{INTRODUÇÃO}

0 presente texto apresenta as dificuldades percorridas pelos surdos em relação à educação de qualidade, comprometida com a emancipação dos sujeitos. Há algum tempo estamos participando das contribuições acadêmicas dos congressos Educere e dispondo sobre as necessidades formativas do surdo, de seus professores, da questão cultural com a inclusão do surdo na escola e outros fatores, o que vem contribuindo para o maior conhecimento das características e necessidades dos surdos. Neste trabalho apresentamos a educação de surdos e suas contradições, por meio da análise de autores conceituados que destacam a singularidade surda, fazemos uso dos nossos próprios trabalhos publicados em congressos anteriores e fragmentos de entrevistas realizadas com fonoaudiólogos formados e atuantes principalmente após a Lei 10.436/02 (BRASIL, 2002), visando a verificação das compreensões e incompreensões dos surdos frente às necessidades educacionais postas com a inclusão, bem como o intenso desejo por uma educação bilíngue de fato e direito. 0 texto divide-se em três sub-itens ou subtítulos que tratam das questões da fonoaudiologia, formação de professores, o implante coclear, as interações e um item ou um subtítulo que aponta para a continuidade e não para intenção de finalizar, todos os itens trazem denúncias, sugestões e evidências de surdos sobre a educação que desejam para si e como hoje é ofertada. Como foi construído com pensamentos diretamente surdos, tomamos a liberdade de, por diversas vezes fazermos uso da primeira pessoa, trata-se de um texto feito por várias mãos e pensado em meio à cultura surda.

\section{CONTEXTO: O QUE É ISSO QUANDO SE FALA NA SURDEZ E SUAS CARACTERÍSTICAS?}

A maior incoerência na questão educacional se dá no impasse entre o que se trata na Constituição de 1988 (BRASIL, 1988), e na própria LDB 9394/96 (BRASIL, 1996) que relatam a busca da garantia de uma educação de qualidade, e as denúncias em relação às vivências surdas no contexto escolar que hoje é ofertado. Como nas palavras que vem servindo de mote para as lutas dos surdos e demais deficientes no Brasil "nada sobre nós sem nós ${ }^{25}$ ", intenta-se a partir deste retrato de investigação apresentar o que são os sujeitos surdos, o que tem recebido em termos educacionais e a intensa necessidade de uma realidade (e não um modelo) educacional que os atenda em suas especificidades.

Estudos das obras de Sacks (1990), Lane (1992) e Strobel (2008), apresentam a surdez num campo que supera a ordem clínica comumente seguida através dos séculos. Os autores destacam que a visão clínica sobre a surdez tem início desde a detecção da "deficiência", conforme destaca Strobel:

para essa comunidade ouvinte, o nascimento de uma criança surda é uma catástrofe porque estão acostumados com o padrão "normalizador" para integrar à vida social e também desconhecem o "mundo dos surdos". Por outro lado, na maioria das vezes o povo surdo acolhe o nascimento de cada criança surda como uma dádiva preciosa e não agem como os pais ouvintes que sofrem exageradamente o desapontamento inicial de gerarem seus filhos surdos, isto é evidenciado nas várias gerações de famílias com todos os membros surdos. (STROBEL, 2008, p.23).

Strobel, nos alerta para a realidade do nascimento de um filho surdo em famílias ouvintes, onde é visto e compreendido por meio da deficiência, Lane (1992), Sacks (1990), e outras inúmeras literaturas e pesquisas, apontam que entre 90 e $95 \%$ dos nascidos surdos, são filhos de pais ouvintes, o que leva a reflexão que tipo de ensino e educação esperam e desejam que seus filhos tenham.

As políticas públicas para a educação de surdos vem desempenhando papel importante no modo de compreender o sujeito, principalmente na educação.

\footnotetext{
25 Tema consagrado no movimento das pessoas com deficiência e que em 3 de dezembro de 2004, Dia Internacional da Pessoa com Deficiência foi amplamente divulgado serviu de lema e vem servindo como bandeira de luta para todos aqueles considerados de algum modo deficientes.
} 
Na Declaração de Salamanca (UNESCO, 1994), já observamos o destaque para a importância da língua de sinais para a formação do surdo, observado no documento no item 19 ou 21, que destaca:

políticas educacionais deveriam levar em total consideração as diferenças e situações individuais. A importância da língua de sinais como meio de comunicação entre os surdos, por exemplo, deveria ser reconhecida e provisão deveria ser feita no sentido de garantir que todas as pessoas surdas tenham acesso à educação em sua língua nacional de sinais. Devido às necessidades particulares de comunicação dos surdos e das pessoas surdas/cegas, a educação deles pode ser mais adequadamente provida em escolas especiais ou classes especiais e unidades em escolas regulares (UNESCO, 1994; item 19 ou $21^{26}$ ).

0 acesso a educação do surdo por meio da língua de sinais, aparece na educação brasileira de fato e direito a partir da Lei 10.436/02 (BRASIL, 2002), a qual oficializa a língua de sinais como segunda língua brasileira, posteriormente regulamentada no Decreto 5626/05, traz suas contradições em termos educacionais no cap. VI artigo 22:

§ 2o Os alunos têm o direito à escolarização em um turno diferenciado ao do atendimento educacional especializado para o desenvolvimento de complementação curricular, com utilização de equipamentos e tecnologias de informação. § 3으 As mudanças decorrentes da implementação dos incisos I e II implicam a formalização, pelos pais e pelos próprios alunos, de sua opção ou preferência pela educação sem o uso de Libras. (BRASIL, 2005).

Schubert (2012a), Schubert e Coelho (2011) e Coelho, Dutra Lins e Schubert, (2013áa, 2013b), já apontavam para a contradição entre a garantia dos direitos adquiridos pelo surdo para a educação de qualidade e aquilo que realmente lhes é ofertado. A inclusão do surdo apresenta-se entre falhas e contradições, primeiro porque a educação bilíngue é quase um mito em solo brasileiro, e segundo, porque como se pode observar o Decreto delega aos pais ou aos alunos a opção da educação de preferência. Mas cabe-nos questionar: se o estudante hoje é orientado pelo clínico para a instituição educacional "precocemente" para aprender e desenvolver-se, quem define o tipo de ensino que irá receber? 0 estudante tem condições de discernir? De decidir que tipo de educação ele quer, sendo ele ainda um bebê? Certamente que não será possível. Compreendemos melhor, por meio da citação de Lane:

ao imaginar como é a surdez, eu imagino o meu mundo sem som - um pensamento aterrorizador e que se ajusta razoavelmente ao estereótipo que projetamos para os membros da comunidade dos surdos. Eu estaria isolado, desorientado, incomunicável e incapaz de receber comunicação. Os laços com outras pessoas seriam desfeitos... Um mundo sem som seria um mundo sem significado. 0 que poderia ser mais importante para o sentido da minha própria pessoa do que o meu meio sensorial, senão a minha linguagem oral. (LANE, 1992, p.26).

0 autor destaca nas páginas 27 e 28, que o erro de tentar imaginar é um erro duplo, pois verdadeiras representações de membros de uma cultura não podem ser consideradas sem a possibilidade de alterações nos seio dessa cultura e se tentarmos por esse meio da imaginação, considerando a característica de ouvir, ou deixar de ouvir, o relacionamento entre ouvintes e surdos e a educação das crianças, jovens e adultos surdos, nunca terá êxito.

O dilema que vivenciamos no presente século são as tecnologias e o aceleramento de tudo, pais mais ausentes, com menos tempo de investimento, facilidade em implantes cocleares e dificuldade de acesso ao "mundo surdo", de interações com crianças, adolescentes e jovens surdos com modelos surdos adultos, que possam desvelar que os surdos são inteiramente capazes, com ou sem tecnologias implantadas.

Em tempos em que se prega a inclusão, continuamos a levantar a bandeira de inclusão inversa, ou seja, a implantação de escola bilíngues para surdos, especial apenas no modo como os sujeitos são atendidos, no

${ }^{26}$ A Declaração de Salamanca é uma resolução das Nações Unidas que trata da educação especial em seus princípios, políticas e práticas. Considerado mundialmente um dos mais importantes documentos, junto à declaração dos direitos humanos; destaca a importância da inclusão e da não segregação de pessoas com deficiência, teve sua origem nos movimentos em favor dos direitos humanos. Utilizamos números diferentes em relação à citação devido à comparação dos documentos do portal Mec e da Declaração em pdf editada pela UNESCO, mas ambas se modificam apenas na enumeração dos itens, o conteúdo não se modifica. 
modo de considerar a língua de sinais em relação à língua portuguesa. Quando o surdo clama para si uma educação especial, quer a educação especializada e não segregada, visto que não quer o abandono do currículo, do ensino, da igualdade de condições e de qualidade, aí se apresenta a primeira denúncia, a partir da pergunta: que tipo de educação vem recebendo o surdo no sistema educacional brasileiro? É realmente inclusiva?

\section{A ESCOLA QUE TEMOS: PARA ELA, QUEM SOMOS}

"O termo surdo é vago" (SACKS, 1990, p, 17). Começamos essa seção com outras perguntas provocativas: Quais as contradições na inclusão cultural e identitária na escola? A formação do professor, porque nos preocupamos com ela? Somos surdos... logo não ouvimos; é só isso que nos caracteriza?

São questionamentos que permeiam as questões surdas na escola em qualquer nível e que vem responder a escolha do título do texto. Ao considerar a história da educação de surdos no mundo, encontramos discursos escritos por ouvintes, relacionados à deficiência, o que não é estranho, pois a língua de sinais só passou a ser estudada e considerada em suas características linguísticas na década de 1960. Em termos históricos, Michel de L'Epée, (abade francês que conviveu, analisou e aprendeu a língua dos surdos na França e por conseqüência fundou a primeira escola pública para surdos, utilizando sinais metódicos desenvolvidos por ele mesmo, tendo como base a língua de sinais aprendida com os surdos), fazia uso de uma tecnologia que podemos considerar 'a mais avançada' que hoje temos em sala de aula brasileira: "o intérprete de Língua de Sinais":

[...] os sinais metódicos de L'Epée permitia aos surdos escrever o que lhes era dito por meio de um intérprete que se comunicava por sinais, "um método tão bem-sucedido que, pela primeira vez, permitiu que alunos surdos comuns lessem e escrevessem em francês e, assim, adquirissem educação (SACKS, 1990, p.27).

Somente um fragmento histórico que destaca o que temos a oferecer aos surdos na atualidade da educação inclusiva no Brasil, na escola do século XXI, acredita-se que a única coisa necessária é a inserção da língua de sinais em sala de aula, ignorando cultura, identidade e por vezes o próprio sujeito. L’Epée é personagem de uma história de sucesso educacional e social para os surdos, não somente desenvolveu os sinais metódicos, como possibilitou aos surdos ascensão social, formação política e cultural, aprendizagem de vários idiomas escritos e fazia exposições públicas de seu método, causando desconforto a países e profissionais que acreditavam que os surdos teriam potencial apenas com o desenvolvimento qualitativo da linguagem oral. 0 que queremos evidenciar, é que o uso do intérprete que tem sido o máximo que a educação inclusiva tem a oferecer, já era utilizado na década de 50 do século XVIII. Seria um retrocesso? Certamente que não. Mas não é o único meio de acessibilidade que os surdos necessitam, já que a educação deve concorrer para a emancipação humana.

Com o congresso de Milão em 1880, professores surdos foram excluídos do processo educacional e os métodos por meio de sinais foram abolidos, proibindo-os de uso da própria língua:

uma das consequências disso foi que a partir de então professores ouvintes, e não professores surdos tiveram que ensinar os alunos surdos. A proporção de professores surdos que e 1850 beirava os $50 \%$, diminuiu para $25 \%$ na virada do século e para 12\% em 1960. Cada vez mais, o inglês tornou-se a língua de instrução de alunos surdos, ensinado por professores ouvintes, dos quais uma parcela cada vez menor conhecia algo de língua de sinais- a situação descrita por David Wright em sua escola na década de 1920. Nada disso teria importância se oralsimo funcionasse... - pagou-se um preço intolerável pela aquisição da fala [...]. 0 oralismo e a supressão da língua de sinais acarretaram uma deteriorização marcante no aproveitamento educacional das crianças surdas e na instrução de surdos em geral. (SACKS, 1990, p.35).

Lane (1992) e Sacks (1990) ressaltam que com a inserção unicamente da língua oral para o ensino e a separação dos pares surdos, fez com que muitas crianças surdas apresentassem atraso, tendo um senso de causação deficiente (não são todas). Isso acontece porque as interações são prejudicadas em um ambiente que não conhece e nem utiliza qualitativamente sua língua de acesso as informações e a própria organização de pensamento. Vigostsky $(1996,1998,2001)$, destaca que para os surdos a língua gestual, ou seja, a língua de sinais deve ser sua língua de acesso a aprendizagem, mas a escola vem desconstruindo em nome da inclusão forçada, o modelo bilíngue de ensino. 
Quando o Estado passa a investir intensamente em implantes cocleares onerosos, mas não investe na abertura de escolas bilíngues como o previsto no Decreto 5626/05 (BRASIL, 2005), cabe-nos pensar em que tipo de visão, de vertente está pautado. Realmente superamos a visão clínico terapêutica que aterrorizou os surdos por longos séculos? A escola que se tem não é bilíngue, nem bicultural, ou seja; não tem a Libras como língua de instrução, mas tem a inclusão como bandeira de luta, onde se afirma que 'todos aprendem com todos'. Mas e o acesso do surdo, ao professor, como se dá? Respondemos sem medo: o intérprete o faz, quando ele está em sala. 0 surdo tem direito ao implante, mas não tem acesso a escola e ao professor bilíngue. A meta 4, no item, 4.7 do Plano Nacional de Educação (BRASIL, 2014), destaca tanto a educação em escolas bilíngues, como a educação inclusiva, mas, o que os surdos desejam é uma educação qualitativa de fato e direito, onde não seja compreendido como deficiente na linguagem e que o professor e toda a comunidade escolar seja capaz de interagir diretamente com ele, sem a necessidade de "recursos de adivinhações ${ }^{27 ": ~ " S e r ~ d e f i c i e n t e ~ n a ~ l i n g u a g e m ~ e ́ ~ u m a ~ d a s ~ c a l a m i d a d e s ~ m a i s ~ t e r r i ́ v e i s ~ p o r q u e ~ e ́ ~ a p e n a s ~}$ por meio da língua que entramos plenamente em nosso estado e cultura humanos e adquirimos, compartilhamos informações" (SACKS, 1990, p.19).

A compreensão de quem o surdo é tem início no diagnóstico clínico, motivo pelo qual a Lei 10.436/02 (BRASIL, 2002) e o Decreto 5626/05 (BRASIL, 2005), trazem como fundamental que o professor em formação, assim como o fonoaudiólogo em formação sejam conhecedores da língua de sinais e das características surdas, mas o que acontece quando os pais são instruídos por profissionais que ainda não compreenderam o que necessitam os sujeitos? Por quais conceitos a fonoaudiologia compreende o surdo? Em que bases estão firmados? Como os surdos chegam à educação? A educação denuncia: "a fono não deixa![...] a fono não quer!"

Não é incomum que pais de filhos surdos instruídos ao implante coclear (por exemplo), utilizem a frase: “[...] a fono não deixa[...]”, quando relacionado à língua de sinais, ainda que a Lei preveja e instrua que a criança surda deve estar em contato com a comunidade surda e com a língua de sinais precocemente, retornamos ao ponto de partida: o diagnóstico clínico e a instrução clínica. O fato de que 90 e $95 \%$ dos surdos tenham nascido em lares ouvintes, nem sempre colaboram com uma escolha positiva do modelo educacional que faz uso de ambas as línguas, pois: “[...] implica a formalização, pelos pais e pelos próprios alunos, de sua opção ou preferência pela educação sem o uso de Libras. (BRASIL, 2005).

Os surdos vêem com tristeza a realidade brasileira em relação às escolhas dos pais e também em relação ao implante coclear, quando esses rejeitam a singularidade, identidade e necessidades surdas. Não pelo uso da tecnologia, mas pelo impedimento de conviver e reconhecer-se enquanto surdo e não como deficiente auditivo, como por longo período histórico foram obrigados a narrar-se e olhar-se, segundo destaca Skliar $(1999,2005)$, esse impedimento de ser surdo e de usar a língua de sinais fez calar a voz dos sujeitos e compreender a si e a sua língua como deficientes. É necessário entender que a criança que passou pelo implante coclear 'é surda', em termos clínicos: surda profunda ou severa, portanto, passa a 'aprender' a ouvir com o implante que se faz internamente após destruir a cóclea (que não funciona) e implantar-lhe eletrodos, mas externamente recebe um aparelho nas orelhas, o qual liga-se como um 'imã' à parte interna e por meio disso a criança 'ouve' (se aprender a ouvir) ${ }^{28}$. Mas o que a maioria dos pais não consideram é que ao retirar o aparelho ele volta a sua condição, reconhecendo ou não: é surda! Pedimos licença para relatar a fala de uma estudante de 14 anos, que recebeu implante coclear na infância, desenvolveu "bem" a fala segundo a fonoaudióloga ${ }^{29}$, mas que ao adentrar uma escola com pares surdos,

\footnotetext{
27 "Referências utilizadas em entrevistas com surdos e com professores de educação inclusiva quando destacam: precisamos tentar descobrir, adivinhar o que ele está tentando dizer", surdos e professores ouvintes na educação inclusiva destacam na maioria das vezes adivinhar o que o outro quer dizer.

28 Não intentamos explicar cientificamente o implante e nem temos domínio, somente exemplificamos para centrarmos na ${ }^{28}$ "Referências utilizadas em entrevistas com surdos e com professores de educação inclusiva quando destacam: precisamos tentar descobrir, adivinhar o que ele está tentando dizer", surdos e professores ouvintes na educação inclusiva destacam na maioria das vezes adivinhar o que o outro quer dizer.

${ }^{28}$ Não intentamos explicar cientificamente identidade.

29 Destacamos como segundo a fono, porque a estudante produz uma fala compreensível para os que convivem com ela, mas com muitas dificuldades na articulação. Destacamos que compreendemos que há surdos que se desenvolvem em níveis excelentes na fala oral, não queremos apontar negativamente ao implante, mas a desconsideração com a cultura e identidade surda inegável, mesmo diante de um implante coclear. 0 direito de ser surdo, mesmo quando pode ouvir, deve ser à base das políticas públicas, onde este sujeito possa participar das vivências surdas e compreender o surdo e com isso a si mesmo para além da deficiência. Muitos dizem que o surdo é contra o implante, mas somos contra a ignorância, a negatividade, a imposição clínica que impede a aquisição bilíngue da língua de sinais e língua oral concomitantemente, para que esse sujeito "implantado" possa viver entre as culturas e compreender-se
} 
adquiriu cultura surda, obrigando a mãe e demais familiares a aprenderem língua de sinais. Ao ser cobrada pelo uso do implante em sala, A.C, aluna de 14 anos responde: "A fono não quer e nem deixa eu ficar sem aparelho, mas eu sou surda e meu aparelho está na bolsa, chega! Não quero! Quando eu quiser ouvir com os ouvidos eu aviso... agora quero ser surda, por favor, me deixem! Não quero!" (SCHUBERT, 2012b).

A estudante demonstrou identificação com pares surdos, desenvolveu rapidamente a língua de sinais e causou indignação a área clínica. Esse é um entre os inúmeros. Sem o implante ele é surdo e com o implante, também. Mais uma denúncia e uma crítica: é preciso compreender os sujeitos para além das aparências, como destaca Kosik (1976) e apreender-lhe a essência, respeitar quem realmente são. Por anos a fonoaudiologia ditou regras sobre como os surdos deveriam ser ensinados, métodos oralistas, intensificação em modelos clínicos. Mas, hoje esse profissional deve ser formado para compreender características, identidades e cultura surda, para alcançar as reais necessidades que os sujeitos têm de reconhecimento e humanização em sua máxima.

\section{E QUANDO A FONO NÃO QUER? E SE A EDUCAÇÃO NÃO SABE O QUE FAZER}

Em trabalhos formais de investigação, é comum deparamos com secretarias de educação que mantém em seu quadro especializado, o fonoaudiólogo e não o professor para organizar, pensar e planejar a educação de surdos; o que reflete a contradição. 0 professor é o profissional especialista que conhece (ou deveria) a cultura e características surdas para a aprendizagem e a fonoaudiologia em seu espaço clínico, trabalha com fatores relacionados à saúde. Porque a crítica? Porque neste caso, a fonoaudiologia retoma o primeiro exemplo, aquele que dita às regras na educação, e uma visão clínica não pode ser imposta educacionalmente, deve haver parceria, mas cada qual ocupa seu lugar.

Apresentaremos fragmentos contidos no trabalho de Schubert (201430) que destacam o modo como fonoaudiólogos pensam o surdo e a educação. Os profissionais da fonoaudiologia que responderam questionários ou participaram de entrevista destacam que usam Libras em nível básico, apenas um de cinco fonoaudiólogos destacou que é proficiente, porque trabalha em uma instituição conceituada em educação de surdos e é o único que participa de formações a respeito: "[...] foco na clínica, mas me interesso pela área educacional[...] acredito no ensino bilíngue com igual atenção as duas línguas[...] infelizmente, vejo uma preocupação maior apenas com a L131" (SCHUBERT, 2014). Os demais relatam que após formação não tiveram cursos relacionados à surdez, e os que fizeram algum curso, este estava relacionado a questões clínicas. Mesmo que esses fonoaudiólogos apontem que acreditam em uma educação bilíngue para os surdos, maior parte deles mostram a contradição, destacando a importância do implante e do uso da oralidade para os estudantes, mas também há quem compreenda a importância de ambas as línguas:

"Acredito na tecnologia, vejo resultados muito significativos para a maioria dos usuários [...] uma língua não irá interferir na aprendizagem da outra a partir do momento que forem trabalhadas igualitariamente em momentos distintos (F.1)" "Quando recebe um implante, teoricamente precisa desenvolver apenas a oralidade, mas é claro que depende de cada pessoa (F.2)"

Perceptível, ou não, a intenção é mais voltada ao desenvolvimento da fala, da oralidade, pois 'passou a ouvir'. Quanto à língua de sinais e afastamento da Libras:

“Destacamos que a criança surda deve ser bilíngue e necessita das duas línguas. Os fonoaudiólogos aconselham o afastamento crendo que irá atrapalhar no treino da oralidade. Mas é um equívoco, ela poderá aprender a falar e sinalizar sem interferência (F.3)"

com e sem o aparelho, possa vivenciar experiências hibridizando-se entre os mundos e as culturas sem entender-se como diferente... deficiente, sem perder o melhor que a vida entre culturas pode oferecer, ou seja; sem aculturação. 30 Ainda em construção a tese da autora envolve a formação de professores para a educação de surdos, onde debate a formação inicial e continuada, a questão da educação bilíngue e os reflexos que se tem na formação do professor em todos os níveis e também do fonoaudiólogo a partir de 2002 com a oficialização da Libras.

${ }^{31}$ L1 significa na área da linguagem: a primeira língua e L2, segunda língua. No caso dos surdos a L1 é considerada a Língua de sinais e L2 a Língua portuguesa. 
Trazemos as contradições de professores investigados que destacam que os estudantes surdos que utilizam o Implante coclear e agora o $\mathrm{FM}^{32}$, um aparelho que vem sendo utilizado na escola, acabam se distanciando cada vez mais da L1 do estudante surdo, visto que a fonoaudiologia vem orientando a aprendizagem dos recursos auditivos. Ainda que não se retire de sala de aula o intérprete de Libras, há uma intensificação das habilidades auditivas e o estudante surdo continua a dividir sua rotina entre atendimentos especializados em contraturno, visitas a fonoaudiologia para treinamento e reabilitação e atendimento em sala de aula 'inclusiva' que não corresponde às necessidades linguísticas e identitárias do sujeito. Ao destacar a inadequação das instruções clínicas que visam centrar a educação de surdos novamente nas bases da segunda língua, intentamos denunciar que o professor que hoje está na educação inclusiva, não domina e nem conhece a língua e as características do estudante surdo o que abre margem para a inserção clínica nas instruções educacionais.

Este é um aspecto importante, pois o trabalho que o professor irá realizar na escola depende muito da sua formação inicial e continuada e também ocorre pelo e no trabalho. 0 professor se forma profissional no processo histórico, nas relações mediadas pelo trabalho e uma proposta de trabalho educativo emancipadora, que compreenda que o trabalho da escola tem como foco a apropriação do conhecimento historicamente acumulado pela humanidade, como um direito de todos; e do trabalho do professor como atividade fundamental nas mediações entre o conhecimento e o estudante; e não das escolhas clínicas para o processo.

Segundo Facci (2004), o professor tem sido responsabilizado pelo seu processo formativo e culpabilizado pelos problemas da escola e da qualidade do ensino. Saviani (2014) destaca que o trabalho docente é condicionado pela formação, e "uma boa formação se constitui em premissa necessária para o desenvolvimento de um trabalho docente qualitativamente satisfatório" (SAVIANI, 2014, p.86). 0 autor ressalta que as condições de trabalho dos professores "também influenciam a própria formação na medida em que o processo formativo implica o aspecto prático que tem como referência a rede escolar" (SAVIANI, 2014, p.87), se a educação bilíngue prevista na legislação, ainda não se faz realidade, também haverá precarização do trabalho, ausência de professores bilíngues e modelos surdos; diante disso é necessário investimento na formação do professor, para melhoria das condições de trabalho e estímulo para estudantes e professores.

A inclusão que a lei prega, não pode estar desarticulada da educação que os sujeitos necessitam, se os surdos requerem para si uma educação que priorize a Libras e alcance qualitativamente, por meio desta também a língua portuguesa é porque almejam uma educação emancipatória para si. Então o que querem é possível? Como alcançá-la?

\section{CONSIDERAÇÕES PARA NÃO FINALIZAR}

visão social:[...]eu junto com um grupo de alunos surdos que passaram no vestibular para Letras/Libras conversar com uma assistente social da universidade [...] elucidei a ela que sou doutoranda e eles alunos da graduação e finalizei explicando o motivo de estar lá, a assistente social pegou o papel para fazer cadastro e perguntou para nós: "Vocês sabem ler?" (STROBEL, 2008, p.23).

O fragmento nos remete ao modo social de compreender os surdos, Karin Strobel, hoje doutora, pode nos relatar inúmeras histórias de exclusão, que nos pede reflexão. Quando "a fono não deixa" é porque a escola não sabe o que fazer e acaba por incapacitar o sujeito, pois muitos não alcançam, mesmo com uso de tecnologias, desenvolver qualitativamente a linguagem. Os professores cada vez mais especializados passaram a buscar conhecimento na língua de sinais, hibridizando-se entre esta e a modalidade oral presente na realidade brasileira, como inculcação pedagógica, até o ano em que a língua de sinais foi

32 O FM é um sistema (transmissor de FM/receptor de FM), uma tecnologia que capta a voz do interlocutor por meio de um microfone sem fio conectado a um transmissor e envia o sinal através de ondas de rádio para surdo que precisa ter um minúsculo receptor de FM conectado ao seu aparelho auditivo ou implante coclear. Ou seja; transmite o som diretamente para o ouvido, com a amplificação adequada, o resultado é uma conexão direta entre a fonte sonora e quem usa o aparelho; a voz é transmitida ao receptor como se o som estivesse bem perto, sem a interferência do ruído de fundo e nem a diminuição do volume causada pela distância, já que o ambiente de sala de aula apresenta muitos ruídos, a intenção é aproximar professor e o aluno, superando a perda de energia do som causada pela distância. Resumo das informações disponíveis em: < http://www.phonak.com/br/b2c/pt/products/fm.html?gclid=CJmZxI2dcYCFReBkQodlvAGcQ> e <http://www.programainfantilphonak.com.br/conheca-um-pouco.php> acesso em 2 de junho de 2015. 
oficializada. No entanto, nos últimos anos, tem-se observado um aumento significativo da inclusão, da separação dos pares surdos e das imposições do pensamento clínico, por meio da presença da fonoaudiologia nas determinações da educação.

Surdos necessitam de professores com formação de qualidade, realmente bilíngues, conhecedores não apenas da língua de sinais (fluentes e proficientes nela), mas também conhecedores de cultura, de identidade e especificidades dos estudantes, que valorizem a singularidade de cada estudante surdo para além das tecnologias de qualquer nível. Desejam que a fonoaudiologia continue a auxiliar a educação do ponto que realmente lhe pertence, de fora das secretarias de educação, quando no máximo com o auxílio no que é de sua competência clínica e não dizendo como ensinar ou até que ponto a língua oral deve fazer parte das vivências escolares dos surdos, pois já está estabelecido o direito.

Para que não fique a apareça que rejeitamos as contribuições da fonoaudiologia, gostaríamos de destacar que entendemos como uma área necessária em sua máxima, desde que observando a educação de longe, pois muitas vezes o professor atem-se mais nas indicações, na falta, do que nas atitudes inclusivas e na aproximação com o sujeito com sua potencialidade. Destacamos que ao questionar os profissionais da fonoaudiologia sobre suas interferências na educação, os mesmos afirmam que indicam e orientam como o professor deve tratar cada sujeito: implantado, com uso do FM e os que estão em treinamento e reabilitação, mas, que respeitam a autonomia do professor. Porém, quando questionados: "[...] Se o professor percebe que o surdo se desenvolve melhor pelas interações em Libras do que com os recursos de oralidade e treinamento auditivo, mesmo que você indicasse apenas a oralidade, por exemplo, você aceitaria?" Eis algumas das respostas: "[...] não sei. (F.1)" “[...] me oporia a indicação do professor; mas na maior parte dos casos não haverá desacordos (F.2)” “[...] aumentaria o horário de atendimento e pediria apoio familiar. (F.3)" (SCHUBERT, 2014).

É necessário que o professor esteja atento a sua ação pedagógica, pois todo diagnóstico abre-se para as possibilidades de trabalho. Quando relacionado ao surdo, exige o conhecimento de quem é o sujeito e suas características visuais estão destacadas no Decreto 5626/05(BRASIL, 2005), bem como o uso da língua de sinais. 0 professor mesmo deve ser usuário desta língua e manter uma parceria com a fonoaudiologia, de modo que essa lhe sirva de base para conhecimentos clínicos a respeito do estudante, mas sem interferências diretas no modo de ensinar. Os pais precisam ter informações educacionais sobre os filhos surdos e não apenas clínicas, para que a qualidade de interações linguísticas seja ampliada e favoreça a aprendizagem presente e futura dos estudantes em qualquer espaço, idade e nível escolar. Os surdos precisam estar atentos as novas gerações, pois com a intensificação da inclusão, os surdos adultos, com formação vêm sendo solicitados para trabalhos mais especializados de ensino da língua de sinais e não percebem o distanciamento e a desmobilização dos movimentos em prol da educação, das identidades e da própria cultura surda.

Ainda que a fonoaudiologia pareça inimiga, ela não é! Deve contribuir para a melhoria da educação de surdos em todos os setores, como parceira, paralela, mas sem interferência em sala de aula como no passado, considerando que sua formação é clínica e a do professore é pedagógica. Destacamos que acreditamos na tecnologia (se assim for da vontade dos pais), como meio de melhorar a audição do sujeito, mas, ressaltamos que o fato de não ouvir, não deve ser motivo de desespero e escolhas invasivas de normalização, pois ser surdo é ser sujeito de vontades, de singularidades, é ter uma cultura, identidade e principalmente ser humano, independente de como a sociedade os veja, surdos são sujeitos com potencial, usuários de uma língua tão importante que faz parte da formação oficial do povo brasileiro. Não somos contra o implante, apenas destacamos que as tecnologias se aperfeiçoam a cada ano, ou meses, portanto ao ultrapassá-la, como dar conta de renová-la naqueles que já adquirem o que lhe foi ofertado. Enfim, o maior anseio é sermos reconhecidos como sujeitos de aprendizagem, que querem máximo que a educação historicamente produzida é capaz de oferecer a todos, independente de suas especificidades, que desejam: que o professor possa interagir diretamente com o estudante, ter pares com quem possam interagir, sem ter que repetir constantemente o dito e o não dito, que sonham com uma educação bilíngue de fato... e não somente de direito, e não nos importamos se alguém não quer... afinal, a Lei já nos permite. Queremos apenas o cumprimento das promessas feitas na Lei. 


\section{REFERÊNCIAS}

[1] Brasil. Lei de Diretrizes e Bases da Educação Nacional- Lei no 9394/96. Brasília, 1996.

[2] Brasil. Plano Nacional da Educação 2014-2024. Lei no 13.005, de 25 de junho de 2014. Brasília: Câmara dos Deputados, Edições da Câmara, 2014.

[3] Constituição $1988 . \quad$ Brasil $1988 . \quad$ Disponível $\quad$ em: <http://www.planalto.gov.br/ccivil_03/constituicao/constitui\%C3\%A7ao.htm>. Acesso em: 16 Jun. 2015. Brasília, 5 de outubro de 1988.

[4] _._. Decreto 5626, de 22 de dezembro de 2005. Regulamenta a Lei no 10.436, de 24 de abril de 2002, que dispõe sobre a Língua Brasileira de Sinais - Libras, e o art. 18 da Lei no 10.098, de 19 de dezembro de 2000. Disponível em: < http://www.planalto.gov.br> Acesso em 16 jun. 2015. Brasília, 22 de dezembro de 2005.

[5] __ Lei n. 10.436/02. Disponível em: <http://www.planalto.gov.br/ccivil_03/leis/2002/L10436.htm>. Acesso em: 16 abr. 2015. Brasília, 24 de abril de 2002.

[6] Kosik, Karel. Dialética do Concreto. Tradução de Célia Neves e Alderico Toríbio. 2. ed. Rio de Janeiro, Paz e Terra,1976.

[7] Lane, H. A máscara da Benevolência: a comunidade surda amordaçada. Tradução: REIS, C. Coleção: Horizontes pedagógicos. Lisboa: Instituto Piaget - Divisão Editorial, 1992.

[8] Facci, Marilda Gonçalvez Dias. Valorização ou esvaziamento do trabalho do professor? Um estudo críticocomparativo da teoria do professor reflexivo, do construtivismo e da psicologia vigotskiana. Campinas, S.P: Autores Associados, 2004

[9] Sacks, O. Vendo vozes: uma viagem ao mundo de surdos. São Paulo: Cia das Letras, 1990.

[10] Saviani, D. Sistema Nacional de Educação e Plano Nacional de Educação: significado, controvérsias e perspectivas. Campinas, SP: Autores Associados, 2014.

[11] Skliar, Carlos. A Surdez: um olhar sobre as diferenças. Porto Alegre: Editora Mediação, 2005.

[12] C Carlos. Atualidade da educação bilíngue para surdos/ Carlos Skliar, organizador. - Porto alegre: Mediação, 1999.

[13] Schubert, S. E. M.; Coelho, L. A. B. Políticas Públicas e a Surdez, quando os discursos se (Des)constroem. In: X Congresso Nacional de Educação. Educere (Anais, comunicação oral), PUC- Curitiba. 2011. p.12046-12053.

[14] Schubert, Silvana Elisa de M. Cultura Surda. Faculdade Educacional da Lapa. Editora FAEL. Curitiba- Paraná. 2012a.

[15] Schubert, Silvana Elisa de M. Notas de sala de aula- Araucária. Paraná. 2012b.

[16] Schubert, S. E. M.; Dutra Lins. E. G. S.; Coelho, L. A. B. Surdos: contradições na inclusão cultural e identitária na escola.In: XI Congresso Nacional de Educação. Educere (Anais, comunicação oral), PUC- Curitiba. 2013a. p.7014-7031.

[17] Schubert, S. E. M.; Dutra Lins. E. G. S.; Coelho, L. A. B. Quando a escola recebe a cultura surda. In: XI Congresso Nacional de Educação. Educere (Anais, comunicação oral), PUC- Curitiba. 2013b. p. 6793-6810.

[18] Schubert, Silvana Elisa de M. Entrevistas com fonoaudiólogos e pedagogos em foração- referências para teseatividade de pesquisa. Curitiba- Paraná. 2014.

[19] Strobel, K. As imagens do outro sobre a cultura surda. Florianópolis: UFSC, 2008.

[20] Unesco. Declaração de salamanca- $1994 . \quad$ Disponível <http://portal.mec.gov.br/seesp/arquivos/pdf/salamanca.pdf > Acesso em: 15 abr. 2015. Salamanca, Espanha, 7-10 Jun. 1994.

[21] Vigotsky, L.S. Pensamento e Linguagem. Rio de Janeiro: Martins Fontes 1996.

[22] Vigotsky, L.S. A Formação Social da Mente: o desenvolvimento dos processos psicológicos superiores. Tradução Neto, J. C.; Barreto, L.S.M.; Afeche, S. C. 6oed. São Paulo: Martins Fontes 1998.

[23] Vigotski, L.S. Pensamento e palavra. In: Vigotski, L. S. A construção do Pensamento e da Linguagem. São Paulo: Martins Fontes 2001. 


\section{Capítulo 13}

\section{Ensino de Português para criança surda na escola regular: Um estudo de caso}

\section{Ana Carla Severo Andrade \\ Pascoal Eron Santos de Souza \\ Ricardo José Rocha Amorim}

Resumo: Este trabalho discute sobre o ensino de português escrito para surdos, abordando os desafios e dificuldades encontrados por professores e por familiares de uma criança com surdez envolvida nesse tipo de processo educativo. 0 trabalho traz 0 resultado de um estudo de caso desenvolvido em torno do processo de ensino da língua portuguesa para um menino surdo de 11 anos, matriculado na rede pública de ensino de uma cidade do interior da Bahia. Além da criança, foram sujeitos da pesquisa sua mãe, uma professora da escola regular e uma professora que faz atendimento educacional especializado (AEE) na sala de recursos multifuncionais da escola. Os dados foram construídos ao longo do processo de observação participante e por meio de entrevistas. O estudo revela a importância da aprendizagem da língua brasileira de sinais - Libras, pelo sujeito surdo, como primeira língua, para tornar viável o aprendizado da escrita do português, que é uma segunda língua para ele. 0 uso de Libras pelos adultos que convivem com a criança, revela-se como fator essencial para o desenvolvimento escolar. Para que o surdo aprenda o português, não é suficiente frequentar aulas em uma escola regular. Este estudo reafirma que é indispensável garantir a ele um atendimento especializado, para que barreiras linguísticas sejam superadas. Os resultados apontam que o domínio do português na modalidade escrita não pode ser tratado como algo menos importante ou como mera exigência escolar; precisa ser assumido pela escola que trabalha com surdos como um instrumento cultural indispensável para a vida em sociedade.

Palavras-chave: Educação de surdos, Ensino de Português para Surdos, Libras. 


\section{INTRODUÇÃO}

0 processo de educação de surdos nas escolas comuns tem sido marcado por barreiras linguísticas que, sem o devido envolvimento da comunidade escolar, dificilmente são superadas pelo aluno com surdez. Práticas comunicativas entre ouvintes e surdos com uso da Língua Brasileira de Sinais (Libras) nas escolas, ainda é uma realidade distante de ser concretizada. Um número significativo de professores em formação inicial tem contato com temáticas relacionadas aos surdos ainda nos cursos de licenciatura, quando obrigatoriamente estudam Libras, mas, não conseguem desenvolver fluência nesta língua, visto que é um contato meramente introdutório que não possibilita um aprofundamento real de seu uso para fins de comunicação.

A pesquisa que deu origem a este trabalho surgiu a partir de alguns questionamentos provocados pelo contato com surdos no ambiente escolar: quando as crianças ouvintes são alfabetizadas, já têm uma experiência linguística como falantes da língua. 0 processo de alfabetização, por tanto, está associado ao desenvolvimento de uma consciência fonológica e é baseado na pauta sonora, ou seja, na associação entre fonemas e grafemas. E a criança surda? Como aprende a escrever uma língua (o português) que os surdos, por sua especificidade sensorial, não falam?

Algumas respostas para estes questionamentos puderam ser encontradas a partir do estudo de um caso específico de uma criança surda matriculada na rede municipal de ensino de uma cidade de pequeno porte, localizada na região do semiárido no interior do estado da Bahia. A pesquisa desenvolvida buscou compreender de que forma acontece o ensino de língua portuguesa na modalidade escrita como segunda língua para uma criança surda, identificando os desafios e dificuldades encontrados pelos professores e pela família envolvidos nesse processo educativo.

\section{METODOLOGIA}

Esta pesquisa foi desenvolvida como estudo de caso por se perceber que este enfoque pode revelar, nas entrelinhas de um contexto único, questões gerais relacionadas ao processo de educação de surdos, sobretudo aquelas diretamente ligadas ao processo de ensino do português nas escolas. As implicações apresentadas estão expostas a partir da relevância de algumas falas dos sujeitos envolvidos no estudo, coletadas por meio de entrevistas semiestruturadas. Neste trabalho, os resultados da pesquisa são apresentados e analisados ao longo do texto, tentando articular as discussões teóricas, baseadas em literatura específica do problema em foco, com os dados empíricos construídos ao longo do desenvolvimento do próprio estudo de caso.

Fizeram parte do estudo, como sujeitos diretos da pesquisa, quatro participantes: um aluno surdo, a mãe do aluno surdo, a professora da escola regular e a professora que atua em uma sala de recursos multifuncionais que faz o atendimento educacional especializado do aluno surdo. Visando a garantia do anonimato da identidade desses sujeitos, são utilizados códigos e/ou nomes fictícios quando for necessário fazer referências a qualquer um deles ao longo deste texto. Sendo assim, a criança surda, principal sujeito deste estudo de caso que, não participou de entrevistas, mas foi observada no ambiente escolar, será identificada como nome de João Pedro; a mãe da criança será indicada apenas pelo codinome "Mãe de J.P.", a professora da criança surda será chamada de "Professora de J.P", e vamos nos referir à professora da sala de recursos multifuncionais como "Professora da S.R."

\section{RESULTADOS E DISCUSSÃO}

\subsection{CARACTERÍSTICAS DOS SUJEITOS DO ESTUDO DE CASO}

João Pedro é um garoto surdo, de onze anos de idade, que vive com sua mãe e irmão ouvintes; é o único surdo de sua família. Estuda em uma escola pública de pequeno porte localizada em um município baiano. Até a última etapa de construção de dados para esta pesquisa, no ano de 2015, ele estava frequentando o quarto ano do ensino fundamental, em uma classe de trinta e cinco (35) alunos. Ele era o único aluno com surdez de toda a escola. As aulas aconteciam no turno matutino de segunda a quinta-feira. A sexta-feira estava reservada para planejamento escolar do corpo docente da instituição; os alunos não tinham aulas neste dia.

A mãe de J.P. é uma senhora com idade entre 35 e 40 anos, tem dois filhos, sendo João Pedro, o mais velho. Segundo o que foi constatado na pesquisa, ela não tem trabalho remunerado, porque acompanha o garoto, semanalmente, a Salvador-Bahia (distante cerca de $400 \mathrm{~km}$ do município onde reside), para fazer 
acompanhamento médico ou para estudar Libras em um centro especializado em educação de surdos da capital baiana. Ela também estuda Libras para contribuir com o desenvolvimento do filho.

A Professora de J.P. tem trinta e cinco anos de experiência e trabalha quarenta horas semanais, em turmas diferenciadas, sendo João Pedro o único aluno surdo com quem, até então, trabalhou em sua carreira. A professora não sabe Libras.

A Professora da S.R. possui um tempo de experiência menor do que a Professora de J.P. (10 anos). Tem conhecimento básico de Libras e é formada em Filosofia. Atua em uma sala de recursos da escola onde o estudo foi desenvolvido. João Pedro é atendido por ela duas vezes por semana.

\subsection{O APRENDIZADO DE LIBRAS COMO PRIMEIRA LÍNGUA}

A Libras não é uma língua universal falada por todo e qualquer surdo. Há, pelo mundo inteiro, várias línguas de sinais. Dessa forma, ela é apenas uma dessas tantas línguas, como esclarece Gesser (2009, p.12): "nos Estados Unidos, os surdos 'falam' a língua americana de sinais; na França, a língua francesa de sinais; no Japão, a língua japonesa de sinais; no Brasil, a língua brasileira de sinais, e assim por diante".

A Língua Brasileira de Sinais possui um sistema linguístico de comunicação gestual-visual, com estrutura gramatical própria, sendo construída a partir de comunidades surdas de outros países (NASCIMENTO, 2006). Essa língua é uma língua natural, que abrange regras morfológicas, sintáticas, semânticas e pragmáticas próprias, assim como o português. É uma língua completa, com uma estrutura independente da língua portuguesa (GESSER, 2009).

Assim como as línguas orais são aprendidas em contextos sociais de interação entre os sujeitos, a Libras também precisa ser aprendida pelos surdos por meio da convivência com falantes dessa língua. De acordo com os relatos da Mãe de J.P., "ele aprendeu Libras, quando começou a frequentar um instituto especializado em criança com necessidades educativas especiais, localizado em uma cidade vizinha ao município onde mora." Inicialmente, segundo ela, os sinais utilizados por ele, eram sinais criados pelos próprios membros da família, para que, dessa forma, se comunicassem e compreendessem o que ele queria dizer. Depois do acompanhamento de João Pedro pelo referido instituto, iniciou-se o aprendizado de Libras por ele e por todos os membros do seu núcleo familiar. Com o passar do tempo, o desenvolvimento de João Pedro acerca da Libras foi se tornando mais significativo e mais complexo. Os gestos que antes eram criados aleatoriamente por ele e por sua família, passaram a ser substituídos por sinais de Libras. Desse modo, conforme os relatos da Mãe de J.P., o aprendizado de Libras envolveu toda a família, possibilitando que ele ampliasse suas possibilidades de interação com a comunidade e com o mundo que o cercam.

\subsection{A EDUCAÇÃO BILÍNGUE COMO MODELO INACESSÍVEL NA ESCOLA DE J.P.}

No modelo de educação bilíngue, proposto para a educação de surdos, defende-se que sejam aprendidas duas línguas: a língua de sinais como primeira língua, e, secundariamente, a língua do grupo ouvinte majoritário. Para que as influências mútuas possam fluir, o surdo deve ser exposto, o mais cedo possível, à língua de sinais, aprendendo a sinalizar tão rápido quanto a criança ouvinte aprende a falar. Ao sinalizar, desde cedo, a criança desenvolve mais plenamente sua competência linguística, que lhe servirá como suporte para aprender outras línguas (FERNANDES, 2008; QUADROS, 2007).

A proposta bilíngue compreende o sujeito surdo como ser integrante de duas realidades, como por exemplo, um estrangeiro em seu próprio país, onde vivencia ao mesmo tempo a realidade da língua materna, na qual tem sua visão de mundo construída e aprimorada, e a realidade de uma segunda língua, nesse caso o português escrito que é utilizado no cotidiano da comunidade a que pertence.

Quando uma instituição busca oferecer uma educação bilíngue, ela está assumindo uma política linguística em que duas línguas passarão a fazer parte da realidade do espaço escolar, sendo que será definida a primeira língua e a segunda língua; nesse caso, a Libras passará a ser a primeira língua e a língua portuguesa será tomada como segunda. Neste sentido, Quadros (2007) afirma que:

0 fato de passar a ter contato com a língua portuguesa trazendo conceitos adquiridos na sua própria língua possibilitará um processo muito mais significativo. A leitura e a escrita podem passar a ter outro significado social se as crianças surdas se apropriarem da leitura e da escrita de sinais, isso potencializará a aquisição da leitura e da escrita do português (p.33). 
0 aluno surdo pode ser prejudicado pela falta de estímulos linguísticos adequados para o desenvolvimento do seu potencial cognitivo, socioafetivo, político e cultural, podendo ter perdas consideráveis no desenvolvimento.

O usuário João Pedro está inserido em escola regular sem professor intérprete, porém observo que o mesmo se encontra na $1^{\circ}$ fase do desenvolvimento linguístico, e isso implica diretamente na necessidade urgente de ser reabilitado linguisticamente em LIBRAS, com aulas de L1 [primeira língua]e L2 [segunda língua] conforme a lei de inclusão e a LDB. Sem a terapia e os atendimentos, João Pedro poderá desenvolver atraso na cognição e distúrbios emocionais (Professora da S.R.).

O ensino bilíngue defende a convivência compartilhada, desde os primeiros anos iniciais, tornando possível (re)construir novas formas de ensinar e aprender, adquirindo novos saberes e valores, compartilhando, dentro do mesmo espaço, interesses e necessidades. Segundo Silva e Nembri (2008), uma educação bilíngue para surdos deve inserir em seu currículo a língua de sinais e a escrita da língua portuguesa como segunda língua em sua plenitude, juntamente com métodos de ensino que tenham características visuais e faça parte da cultura desses sujeitos.

Na educação de surdos, é crucial desenvolver as estratégias de ensino a partir de uma base visuoespacial, já que os sons não têm significação para esses sujeitos. Em alguns momentos das aulas de João Pedro, esta perspectiva é realizada.

No regular [ensino regular] comecei a trabalhar as letras o "E" maiúsculo e minúsculo, já sabem diferenciar. Eu comecei trabalhar com imagens de pessoas para que aquelas letras maiúsculas sejam utilizadas, aí eles descobriram que existem dois "e", eles foram observando, passando a compreender que são dois (Professora de J.P.).

É importante destacar que o uso de algumas estratégias visuais nas aulas, não garante que o ensino seja bilíngue. Na verdade, a escola onde João Pedro está inserido não possui uma proposta bilíngue, isso ficou evidente nas observações feitas durante visitas frequentes à escola. As metodologias e as aulas foram totalmente estruturadas para uma sala de ouvintes. Segundo a fala das professoras entrevistadas, uma das maiores dificuldades para se conseguir avanços na educação de surdos no município em que João Pedro estuda, é encontrar pessoas capacitadas para atuar nessa área, ou seja, intérpretes e professores de Libras. A Professora da S.R., por exemplo, não possui formação específica nessa língua.

\subsection{O ATENDIMENTO EDUCACIONAL ESPECIALIZADO DE J.P.}

A lei de Diretrizes e Bases da Educação Nacional n 9394/96 estabelece, em seu Art.58, que a educação dos alunos com necessidades especiais, deve acontecer preferencialmente na rede regular de ensino e prevê o apoio especializado nas escolas regulares para atender as peculiaridades dos alunos surdos. 0 atendimento disponibilizado pelas escolas, por meio das salas de recursos multifuncionais, deve acontecer em horários que não coincidam com os horários em que a criança está frequentando aulas na escola regular.

0 atendimento educacional especializado na escola de João Pedro é feito em uma destas salas de recursos. A profissional que trabalha naquele espaço atende, em horários específicos, alunos com diferentes deficiências e necessidades. 0 trabalho desenvolvido com João Pedro é voltado para a aprendizagem da língua portuguesa na modalidade escrita.

É notória a empolgação de João Pedro quando chega à sala de recursos. 0 aluno percebe que, naquele espaço, ele é compreendido e sua mãe participa de todas as aulas, para aprender e contribuir com sua aprendizagem. No entanto, há certa dificuldade na execução das atividades propostas para o aprendizado do português, como pontua a Professora da S.R,

Se eu focar só na questão da escrita para eles aprenderem, eles começam achar muito chato, tem vezes, que eles fazem assim (sinal com a cabeça que não aguentam mais) por que de manhã já copiam, para, de tarde, fazer a mesma coisa. Geralmente, eu coloco no computador, ou montamos um quebra-cabeça; mas, sempre utilizando o português [...] vou variando. 
O ensino significativo da escrita, para além da mera reprodução pela cópia descontextualizada, ocupa ainda ínfimo lugar, se compararmos com sua importância no processo educativo da criança surda; pois, em muitos casos, se revela como uma prática reducionista e mecânica sem uma função social clara. Ainda é comum encontrar nas escolas, práticas pedagógicas voltadas para o treino repetitivo com o traçado de letras ou com a repetição de sílabas, que se tornam para os surdos atividades sem sentido.

\subsection{APRENDIZADO DA ESCRITA PELO SURDO}

O surdo, ao ser matriculado na escola comum, geralmente não possui um conhecimento sistemático da Libras, o que dificulta a aquisição da língua portuguesa como uma segunda língua (FERNANDES, 2008). Neste sentido, é preciso criar oportunidades educacionais adequadas, utilizando o ensino simultâneo de ambas às línguas, ou seja, buscar aperfeiçoar sua primeira língua para que seja um facilitador da segunda. Trabalhar a aquisição da língua portuguesa com os surdos e utilizar, a todo o momento, recursos visuais nas estratégias de aprendizagem pode ser um caminho favorável para o desenvolvimento desses sujeitos.

É preciso fazer atividades constantes para ver em que nível ele [o aluno surdo] está. Quando se trabalha com imagens eles aprendem, pois, eles utilizam a visão, agora eu não posso estar passando uma coisa que ele não sabe (Professora da S.R.).

Diante disso, é possível afirmar que não é a surdez que impedirá o processo de aprendizagem do português escrito pelo aluno surdo. No entanto, é preciso que esta aprendizagem seja fundamentada na primeira língua (Libras), dando a ele subsídios no processo de alfabetização.

A aquisição da escrita por João Pedro tem sido um processo lento. A professora tem que mostrar figuras e, em seguida, mostrar os sinais em Libras e a escrita em português. Muitos alunos surdos têm dificuldade no aprendizado, mas isso não significa que não possam aprender. Por isso, é importante que os alunos com surdez, aprendam primeiro a sua língua materna, ou seja, a Libras.

A leitura e a escrita para o aluno surdo são a base para sua inserção no mundo letrado, ampliando seu potencial para interação social e para o processo de construção do conhecimento (PEREIRA, 2008; OLIVEIRA, 2007). A organização didática para o ensino de surdos, nas classes comuns ou no atendimento educacional especializado, implica o uso de muitas imagens e de todo tipo de referências visuais que possam contribuir com o aprendizado dos conteúdos trabalhados. 0 que torna esse aprendizado um desafio ainda maior, no caso de João Pedro, é a falta de pessoas com formação específica para trabalhar com a educação de surdos. A Mãe de J. P. vivencia essa problemática com frequência:

Eu acho que o problema é na escola, porque...Tem professor que vai pedir explicação para ela (professora da sala de recursos), outras vezes, é a de recurso que vai, mas não ajuda muito, ele já andou em duas escolas diferentes. (Mãe de J.P.).

Para permitir às crianças surdas o domínio da língua, é fundamental que exista um ambiente de leitura e escrita, no qual a participação constante delas seja garantida. Dessa forma, poderão compartilhar a língua escrita como uma prática social. Ensinar uma língua escrita para quem desconhece a oralidade é um desafio para todos os professores com alunos surdos em suas turmas.

As principais dificuldades não decorrem da surdez em si, mas da falta de conhecimento da língua portuguesa, o que dificulta o processo de aprendizado.

De certa forma, o ouvinte tem a voz, a fala, ele consegue absorver o som(...), Ele até vai falando as palavras, assim se você está trabalhando as sílabas, "ba, be, bi, bo e bu".0 "ba" de bala, se eu disser qual sílaba começa a palavra bala, o ouvinte vai responder começa com Ba; já o surdo, mesmo que ele esteja vendo, é um processo para que eles assimilem, por que o dele é tudo visual.. Então, existem essas questões. (Professora da S.R).

Superando esta perspectiva de aprendizagem pela silabação, Soares (2005) defende que a alfabetização ocorre por meio de práticas sociais de leitura e de escrita, ou seja, através de atividades de letramento, e esse, por sua vez, só se realiza verdadeiramente a partir da compreensão das relações entre fonemas e grafemas. Cabe esclarecer que a apropriação da linguagem escrita ocorre, inicialmente, com um processo complexo de primeira ordem, momento em que os signos escritos identificam os sons e palavras da linguagem oral, que, por sua vez, representam os signos de objetos e relações reais (VYGOTSKY, 2005). 
Apesar das afirmações do parágrafo anterior fazerem pleno sentido em relação ao fenômeno da aprendizagem da escrita por crianças ouvintes, para os surdos, essa aprendizagem não tem relação nenhuma com a ideia de grafar fonemas a partir da oralidade. É indispensável que outras estratégias sejam encontradas. Tentar alfabetizar os sujeitos surdos como se alfabetizam os sujeitos ouvintes, tem sido um erro recorrente nas escolas desde quando este grupo de alunos começou a frequentar as instituições de ensino (NASCIMENTO, 2006; QUADROS, 2007).

A escola que não se prepara para atender alunos surdos acaba agindo de forma negativa no desenvolvimento dessas crianças, podendo prejudicá-las. É interessante repensar os espaços da escola em suas várias dimensões, levando em consideração não só a inserção de novos métodos de ensino e aprendizagem, como também a qualificação de profissionais.

É importante lembrar que, mesmo que não alcancem os mesmos resultados obtidos pelos alunos ouvintes num primeiro momento, os estudantes com surdez precisam participar sistematicamente de todas as aulas. O recomendado, no entanto, é que as aulas nas classes comuns sejam enriquecidas com elementos visuais. Sobre este aspecto, destaca uma das professoras de João Pedro:

O surdo não ouve o professor. Teria que ter a imagem, para na hora que ele colocar lá no quadro o assunto, teria que ter uma imagem para representar, ou um cartaz. O desenvolvimento do surdo para ouvinte existe uma diferença. Porque o aluno surdo é tudo na visualização e Libras (Professora da S.R.).

Dessa forma, infere-se que os professores são constantemente desafiados a tornar suas aulas significativas para todos os alunos. Há um ganho qualitativo quando a escrita começa a ter um significado simbólico de valor social para o sujeito surdo. Nesse momento, a criança passa a refletir sobre o que deve anotar; ela compreende que pode usar signos para escrever qualquer coisa, embora ainda não consiga fazê-lo plenamente. Peixoto (2006), ao estudar as interfaces entre a Libras e o português escrito, afirma que a diferença é que a língua de sinais constitui um apoio, um lugar de reflexão e de atribuição de sentido ao texto escrito o qual possibilita um diálogo entre os elementos e as características dos dois sistemas da língua.

Durante esse processo, é indispensável entender o que significa ensinar e aprender a escrever. Esse questionamento, muitas vezes, é esquecido pela maioria dos educadores; o que resulta, quase sempre, em práticas pedagógicas nas quais os alunos são submetidos a uma perspectiva de abandono e solidão. Os alunos devem ser sempre participantes ativos no processo de aprendizagem da linguagem escrita para sua formação como construtores de frases e textos, tornando-se capazes de interagir pela escrita em diferentes momentos de sua vida.

O caso de João Pedro possibilita perceber que as dificuldades encontradas no processo de ensino do português para uma criança surda, não estão necessariamente relacionadas a eventuais deficiências do aluno, mas a fragilidades das instituições de ensino que não dão conta de qualificar adequadamente os profissionais para desenvolverem um trabalho pedagógico mais significativo, seja no aprendizado da língua escrita, seja na participação em processos de construção do conhecimento com os sujeitos surdos.

\section{CONSIDERAÇÕES}

As discussões suscitadas ao longo deste estudo de caso permitem destacar que, ao ensinar português para uma criança surda, o professor não está apenas ensinando esse sujeito a ler e a escrever, está contribuindo para a construção de pontos norteadores indispensáveis para a significação da leitura e da escrita por esse aluno, ampliando suas possibilidades para a construção do conhecimento e seu pleno desenvolvimento. João Pedro, apesar de não ter dominado completamente a escrita do português durante a realização da pesquisa, demonstrou avanços qualitativos na sua relação com a escola e com a comunidade da qual faz parte.

Por outro lado, percebe-se a necessidade de reconhecer que o maior equívoco cometido no ensino da escrita para surdos é, de certo modo, utilizar estratégias baseadas na oralidade ou na reprodução mecânica de palavras, sem levar em conta a necessidade da escrita a partir de uma base visual, tornando-a significativa para o sujeito surdo. 0 domínio da língua portuguesa na modalidade escrita não pode ser tratado como algo menos importante ou como uma exigência da escola, mas precisa ser apresentado à criança como um instrumento cultural indispensável para a vida em sociedade.

Diante do exposto, é importante destacar que este estudo de caso não teve a pretensão de abordar todos os aspectos relacionados ao aprendizado da escrita do português pelo surdo; mas, os recortes aqui 
abordados, construídos a partir da experiência concreta dos sujeitos desta pesquisa, abrem possibilidades para que outros estudos sejam desenvolvidos, buscando responder questões que possivelmente ficaram em aberto ou surgiram como resultado do próprio ato de pesquisar.

\section{REFERÊNCIAS}

[1] Baptista, C. R. Ação pedagógica e educação especial: sala de recursos como prioridade na oferta de serviços especializados. Rev. bras. educ. espec., Marília, v. 17, n. spe1, p. 59-76, Ago. 2011.

[2] Carvalho, M. Guia prático do alfabetizador. São Paulo: Ática, 2010.

[3] Damázio, M. F. M. (2005). Educação escolar de pessoa com surdez: uma proposta inclusiva. 2005. 121 f. Tese (Doutorado em Educação) Universidade Estadual de Campinas - UNICAMP, Campinas - São Paulo.

[4] Brasil. Declaração de Salamanca e linhas de ação sobre necessidades educativas especiais. Brasília: Cortez, 1994.

[5] __ Lei Federal no 10.436, de 24 de abril de 2002.

[6] Falcão, L. A. B. Educação de surdos: ensaios pedagógicos. Recife: Ed. do Autor, 2012.

[7] Fernandes, E. Surdez e bilingüismo. 2. ed. Porto Alegre: Mediação, 2008.

[8] Gesser, A. Libras? Que língua é essa?: crenças e preconceitos em torno da língua de sinais e da realidade surda, 2009.

[9] Nascimento, L. C. R. Um pouco mais da história da educação de surdos. Educação Temática Digital, Campinas, v.7, n.2, p.253-262, jun. 2006.

[10] Oliveira, J. B. A. Comissão de educação e cultura. Grupo de trabalho alfabetização infantil: os novos caminhos: relatório final. 2.ed. Brasília: Câmara dos Deputados, Coordenação de Publicações, 2007. (Série Ação Parlamentar; n. 246).

[11] Peixoto, R.C. Algumas considerações sobre a interface entre a língua brasileira de sinais (Libras) e a língua portuguesa na construção inicial da escrita pela criança surda. Cadernos Cedes, 26, n. 69, p. 205-29, 2006.

[12] Pereira, R. C. Surdez: aquisição de linguagem e inclusão social, 2008.

[13] Perlin, G. T.T. Identidades Surdas. In: SKLIAR, C. (org.). A surdez: um olhar sobre as diferenças. Porto Alegre: Mediação 1998.

[14] Quadros, R. M.; Perlin, G. (orgs.). Estudos surdos II. Petrópolis, RJ: Arara Azul, 2007.

[15] SILVA, A. C. Surdez, educação de surdos e sociedade. In: ; Nembri, A. G. (orgs.). Ouvindo o silêncio: surdez, linguagem e educação. Porto Alegre: Mediação, 2008.

[16] Silva, M.P.A. A construção de sentimentos na escrita do surdo. São Paulo: Plexus, 2001.

[17] Skliar, C. B. A surdez: um olhar sobre as diferenças. 3. ed. Porto Alegre: Mediação, 2005.

[18] Soares, M. Letrar é mais que alfabetizar. In: Nossa língua, nossa pátria. Rio de Janeiro: Jornal do Brasil, 26/11/2005. Entrevista. Disponível em <http://intervox.nce.ufrj.br/ edpaes/magda.htm> Acesso em: maio 2016.

[19] Vygotsky, L.S. A formação social da mente. São Paulo: Martins Fontes, 2005. 


\section{Capítulo 14}

\section{Inclusão de deficientes visuais na escola: Um paradoxo}

\section{Heloisa Valeria Mangia Torres \\ Maria Roselene Soares Marques}

Resumo: Este trabalho pretende, por meio de dois depoimentos (de uma professora e de uma estudante), exprimir as angústias em relação ao processo de inclusão de estudantes com deficiência visual no Colégio Pedro II, no Rio de Janeiro. A análise das experiências refletidas entre os dois sujeitos agentes deste processo busca registrar o paradoxo que se esconde por trás da ideia de inclusão, tendo em vista o despreparo, a desinformação e a falta de cuidado por parte das autoridades. Tanto para a professora quanto para a estudante, os sentimentos dominantes são de ansiedade, dúvida, luta constante pela concretização de um direito que é oferecido ao mesmo tempo que é negado. 0 sucesso escolar de um deficiente visual fica na dependência de sua força pessoal, de sua coragem e determinação e da flexibilidade e criatividade de professores que insistem na educação como arma transformadora, como veículo de ressignificação de si mesmos enquanto profissionais e enquanto seres humanos.

Palavras-Chave: inclusão, Colégio Pedro II, experimentação, paradoxo. 


\section{INTRODUÇÃO}

A realidade da sala de aula absorve e, muitas vezes, nubla as possibilidades de reflexão acerca do próprio processo que se experimenta no cotidiano escolar, de modo que pode se abrir uma espécie de vácuo entre o vivido e o pensado, entre o concreto e os múltiplos abstratos dos diferentes contatos com o humano, o pessoal, o particular de cada professor e de cada estudante. A sala de aula, como espaço-síntese da sociedade como um todo, serpeia um continuado movimento de expansão e retração a partir da oportunidade de expressão de cada segmento humano que a habita ou de sua negação. 0 objetivo deste trabalho é propor a discussão acerca desta realidade que, de modo geral, funda-se como falta, como uma sequência de silêncios que formalizam a precariedade da educação pública verdadeiramente inclusiva.

Observa-se que há, entre a ideologia da inclusão e sua consumação, um degrau irregular, talvez alto demais para pequenas pernas, uma vez que a escola que recebe o estudante com deficiência visual, de acordo com nossa experiência, não consegue se flexibilizar para atendê-lo plenamente em todas as suas necessidades, deixando-o à mercê não só da vontade ou da disposição de professores, mas também de suas condições e habilidades pessoais, de suas dificuldades e limitações.

Na prática, o que se observa é a distância entre os primeiros planejamentos da proposta de inclusão, os conceitos e objetivos iniciais e sua efetivação, uma vez que esta depende da percepção do outro - do estudante sujeito de seu processo de aprendizagem, mas, ao mesmo tempo, objeto de análise e estudo para o professor, assim como do professor, igualmente sujeito-objeto de análise, quase tão frágil e sem amparo técnico e administrativo.

Em princípio, enfrentamos o silêncio como se ele fosse a única possibilidade, ponte absoluta para o que estávamos prestes a viver. E nos calamos também. Romper o silêncio, portanto, é a intenção deste texto, que tem valor de depoimento sem embasamento científico e sem estudos preliminares, mas se oferece para a busca por compreensão de muitos erros, para a reflexão do professor em seu papel de se desdobrar entre ser aquele que transmite conhecimento, e, principalmente, tenciona adquirir os meios de realmente poder incluir sem distinção. Neste sentido, somamos os depoimentos: estamos juntas, a professora Heloisa e a estudante Maria Roselene, expostas e dispostas a contar essa história que, de algum modo, foi significativa, segundo acreditamos, para construir a nossa história individual dentro do processo de inclusão do estudante deficiente nas escolas, mas pode representar também a história de muitos outros professores e alunos na mesma situação.

\section{METODOLOGIA}

Este trabalho é resultado de dois olhares: o meu, como professora que vivenciou dois anos de experiência com estudantes deficientes visuais (anos de 2016 e 2017), no Colégio Pedro II, Unidade Realengo II, Rio de Janeiro e o da estudante Maria Roselene, minha aluna neste período e, hoje, cursando Letras na UFRJ.

De minha parte, é uma resposta surpreendentemente feliz para a ausência de teorização e de estudo sobre práticas pedagógicas inclusivas, visto que estas não aconteceram. Eu estava concluindo o Doutorado em Literatura Comparada e não conseguia planejar aulas ou preparar material nem para as turmas regulares nem para os estudantes com deficiência. A Metodologia, portanto, caracteriza-se pela falta - não houve método. 0 que houve foi a necessidade imperiosa de responder ao apelo dos estudantes, entre os quais a Maria Roselene. Movida pela urgência da presença desses estudantes em minhas aulas, pela ansiedade diante da iminência do fracasso, trabalhei com eles em tempos vagos com leituras e redações extras.

Já eu, Maria Roselene, como estudante, compartilho com enorme alegria essa história que, embora tenha se iniciado mediante a muitas dúvidas, medos e inseguranças, se solidificou em bases fortes de afeto e gratidão.

Fui aluna da Professora Heloisa no segundo ano do ensino médio. Embora meus colegas e eu já estivéssemos no colégio há um ano, o medo de fracassar e decepcionar os que acreditavam em nós, ainda nos assombrava. Com pouco mais de um mês de aula, a professora Heloisa passou a dar aulas para meus colegas e eu no Núcleo de Atendimento às Pessoas com Necessidades Específicas (NAPNE). No início, estávamos todos muito perdidos, mas não demorou muito, tanto ela quanto nós, conseguimos romper todas as dificuldades que nos separavam e juntos construímos todas as aulas que deram mais do que certo. 0 resultado veio pouco tempo depois: além de ter despertado o meu interesse pela leitura e desenvolvido a minha escrita, as aulas da Heloisa deram tão certo, que consegui passar no vestibular para duas universidades públicas com notas acima da média nas redações. A sensação final foi de muito orgulho, gratidão e missão cumprida. 
Atualmente, curso Letras na UFRJ e sou grata por meus colegas e eu sermos frutos de um trabalho de troca de aprendizado que valeu muito a pena.

\section{RESULTADOS E DISCUSSÃO}

Primeiro olhar:

O Colégio Pedro II recebe estudantes deficientes visuais do Instituto Benjamin Constant, situado no Rio de Janeiro e os direciona às séries e turmas regulares com o apoio do Napne - Núcleo de apoio a pessoas com necessidades especiais. Os estudantes têm direito a um computador dotado do sistema DOSVOX, baseado no uso intensivo de síntese de voz, desenvolvido pelo Instituto Tércio Pacitti (Núcleo de Computação Eletrônica (NCE) da Universidade Federal do Rio de Janeiro (UFRJ) (BORGES, J. A.; BORGES, P.P. 2019). Além disso, têm, além das aulas convencionais, junto com a turma em que estão inseridos, aulas extras com professores em horários de contraturno. A gentileza e o carinho dos profissionais do grupo do Napne de Realengo merecem destaque, especialmente em virtude do diferencial que representam na experiência dos estudantes e de professores. São profissionais que lutam contra o grande número de estudantes com realidades e necessidades muito diferentes; o déficit no quantitativo de funcionários e mais problemas de ordem estrutural. Lidam, assim, com um sistema minado segundo o qual a proposta de inclusão se estabelece como paradoxo - os estudantes estão alocados na instituição de ensino e, portanto, teoricamente, incluídos, porém, estão envoltos em um silêncio de desinformação e despreparo que os exclui e limita, abandonando-os, na prática, à sua força pessoal, à sua coragem e impulso de transformar a sua realidade de vida através da educação.

Sou professora de Português e Literaturas e trabalho com o Ensino Médio há mais de trinta anos. Minhas aulas procuram ser simplesmente centradas na leitura e interpretação de textos. Leio para os meus alunos e leio com os meus alunos. Desta forma, tenciono provocar o prazer da leitura, despertar a compreensão das metáforas que vestem o texto como símile do mundo. Recebi os estudantes deficientes visuais com grande apreensão: como seria a leitura deles a partir de estímulos auditivos? Como seria a escrita sem os modelos prévios e convencionais? Minhas dúvidas foram respondidas com o silêncio, com a sensação (que carrego ainda e que motiva este texto) que é a de que toda a ideia de inclusão se faz de modo experimental, no jogo de tentativa e erro, contando com os múltiplos gatilhos e improvisos que longos anos de trabalho me proporcionaram.

O silêncio se instalou como surpresa e susto mesmo, quando eu não fui comunicada de que encontraria, em minha sala de aula de segunda série do Ensino Médio, estudantes com deficiência visual. Os estudantes pareciam tensos e eu recebi sua tensão e a engoli tímida. Recebi dos jovens instruções rápidas, em voz baixa, sobre como eu deveria fazer para que eles acompanhassem minhas aulas - comandos simples: falar alto e pausadamente tudo o que eu escrever no quadro. Passei a trabalhar sob a manta dessa tensão que aquecia o medo do fracasso. Suas demandas me fizeram continuamente repensar, remoer as possibilidades de transpor as barreiras das minhas limitações: eu não sabia como fazer. Dependia dos estudantes para me ensinarem a trabalhar com eles. Tinha de aprender a me posicionar em sala de modo que minha voz ficasse clara e acessível para todos; a formatar os textos e salvar em TXT; a adaptar as provas para facilitar sua leitura; a construir com eles uma linha de compreensão. Enfim, mesmo depois de tantos anos de prática, tive de aprender tudo. Passei a olhar minha sala de aula como espaço de um grande aprendizado pessoal onde aprendi mais do que ensinei.

Ao contrário do que se poderia imaginar, eles não esperavam que eu lhes desse mais oportunidades do que as que eram naturalmente dadas aos estudantes regulares. Eles me exigiam tratamento igualitário e, quando o resultado não era muito bom, explicavam-se como adolescentes normais que às vezes não gostam muito de estudar. 0 preconceito fechado ao redor de pessoas com deficiência que eu nem sabia que tinha foi se quebrando em função dessa atitude - eles me ensinaram mais essa lição: eles não são diferentes. São jovens com os mesmos anseios, as mesmas buscas, sonhos e esperanças de todos os outros de sua idade. No entanto, o mundo não os reconhece assim e precisávamos vencer o mundo. Passei a ler mais para eles e a cobrar mais leitura. Fui dura e rigorosa muitas vezes. Exigia que escrevessem mais redações que os demais estudantes. 0 fracasso, felizmente, não veio: esses jovens superaram todas as expectativas e foram aprovados no ENEM. Hoje são universitários. 


\section{Segundo olhar:}

Não há dúvidas de que a escola desempenha um papel fundamental na formação de qualquer indivíduo. As experiências vivenciadas neste ambiente, sejam elas positivas ou negativas, tornam-se aprendizados que os alunos levarão consigo durante toda a sua trajetória. Por isso, é importante que a experiência escolar seja a mais agradável possível. É compreensível que existam problemas nesse processo, mas não que a escola seja um deles. Quando a inserção do aluno se torna um problema, porque ela, a escola, não se é capaz de atender a todos os seus estudantes de forma igualitária, fazendo com que um grupo tenha que lidar com contratempos além dos comuns, é perceptível que chegamos a um ponto nebuloso e tenebroso, em que o aluno precisa se adaptar à escola e não o contrário. Assustadora ou não, essa é uma situação que se faz presente diariamente na vida de diversos estudantes, em especial, na vida do estudante com deficiência, pois este, além de lidar com todos os empecilhos comumente enfrentados por qualquer outro estudante, ainda tem que lidar com outras mazelas como o preconceito e a falta de preparo para recebê-lo.

Muito se tem falado sobre inclusão, no entanto, de que forma ela acontece? Ela ocorre da melhor forma possível? O cenário que vivenciamos atualmente responde por si só a essas perguntas: existem alunos aprovados automaticamente, devido ao despreparo evidente dos professores; a infraestrutura da escola diz permitir a estadia do aluno naquele espaço, mas, ao mesmo tempo, oferece riscos que comprometem diariamente a sua mobilidade; os materiais muitas vezes não são adaptados, isto é, não são disponibilizados de forma acessível - o que não significa que devam ter conteúdo mais fácil, privilegiando o aluno com deficiência, como algumas pessoas podem pensar, mas que neutralizem a deficiência de modo a posicionar o estudante deficiente em condição de igualdade com os demais. Inclusão não deve, ou, pelo menos, não deveria, apenas inserir um aluno com deficiência no meio escolar - isso é forjar uma falsa inclusão. Isso nada mais é que um reflexo da hipocrisia da sociedade, em que a pessoa com deficiência é vista como super-heroína, mas ao mesmo tempo, incapaz de aprender e ser tratada como um aluno dito "normal".

O que deveria ocorrer, para além da inserção, é a inclusão destes alunos, uma vez que se compreende que a deficiência do aluno se torna inversamente proporcional ao preparo da escola frente a suas dificuldades, ou seja, quanto mais recursos a instituição oferecer para o aluno, menos deficiente ele se torna. 0 dicionário nos informa que deficiência é a falta de algo, portanto, se a escola oferecer condições suficientes para que o aluno possa ter a mesma qualidade de ensino de um colega de classe que não possua qualquer deficiência, esta falta será suprida, tornando-o menos deficiente. Por exemplo, no caso da deficiência visual, a presença de pisos táteis e materiais em braille ou áudio reduzem consideravelmente as dificuldades enfrentadas, já que com esses recursos ocorre uma maior independência do aluno, visto que ele, assim, pode circular sozinho pela escola e estudar por conta própria, sem que alguém tenha que estar ao seu lado para ler os textos ou ajudá-lo em atividades semelhantes. É notório que há uma deficiência também por parte das instituições, pois estas carecem de recursos e metodologias para inserir de fato o aluno nesse ambiente.

A inclusão praticada de forma errônea acaba gerando muitas vezes uma enorme insegurança no estudante com deficiência, pois este passa a se enxergar como o diferente, o intruso, aquele que é pretensioso e está ocupando um espaço que não é dele. No entanto, enquanto aluna com deficiência, tenho a certeza de que não sou pretensiosa e que apenas ocupo um espaço que foi conquistado ao longo do tempo por gerações anteriores e que deve ser cada vez mais ocupado, para que as demandas cresçam e para que nossa voz possa ser ouvida não mais como murmúrios de reclamação, mas sim como gritos por igualdade.

Para que a educação inclusiva ocorra de maneira eficiente, é imprescindível que os professores estejam, assim como a escola, dispostos a mudar, a investir no novo e nas reinvenções de metodologias de ensino. Como estudante com deficiência visual, posso dizer que ainda há muito que ser melhorado no que diz respeito à inclusão. No entanto, durante todo esse processo de aprendizado, entendi que a inclusão é um processo de via de mão dupla, em que o incluído trabalha junto com quem inclui. Com a troca de experiências entre ambas as partes, o processo além de enriquecedor, torna-se também mais eficaz.

\section{CONSIDERAÇÕES FINAIS}

Entende-se, portanto, que o processo inclusivo, apesar dos grandes avanços, ainda tem muito que progredir. Os receios e as incertezas não podem mais continuar constituindo o processo como elementos principais. Além disso, a falta também não pode continuar se configurando como a única metodologia dos professores. Aqui, entre nós duas, a experiência deu certo e tivemos um resultado feliz. No entanto, sabemos que nem sempre ocorre dessa maneira, posto que a ausência de preparo dos professores, 
juntamente com o medo carregado pelos alunos, converte-se, muitas vezes, nesse silêncio. Silêncio que, quando não rompido, reverbera paradoxalmente em ecos crescentes de perguntas sem respostas que se findam em um resultado falho.

A educação é arma de transformação. É preciso acreditar nela e no todo que a compõe. É preciso investir nas novidades e quebrar antigos paradigmas. Vemos que podemos seguir em busca de mudança e lutar pela igualdade, de modo a fazer o processo valer a pena. Assim, quando a inclusão ocorrer de fato dentro das escolas, poderemos esperar por uma sociedade mais empática, em que o colocar-se no lugar do outro possa se tornar uma atitude recorrente.

Com cada vez mais deficientes ocupando as escolas e as universidades, é certo que caminharemos, mesmo que em passos lentos, para um grande progresso educacional, de forma que a inclusão de fato se consolide e não se mostre apenas a integração praticada por um ou outro profissional.

O sucesso de estudantes como Roselene e seus colegas se deve a uma entrega de vida. É uma resposta ao descaso, ao silêncio e à falta, pois nega o paradoxo em que se estabelece este texto. Apesar de todos os impedimentos e do sonoro "não" que a estrutura social e, especialmente, a base que fundamenta a escola lhes oferece, eles seguem armados com bengalas e sorrisos, como guerreiros de uma batalha, em princípio, condenada pelo preconceito. Como professora, considero que a luta que enfrentamos pode servir como exemplo de contestação para todas as vezes em que o "não" se manifestar - é a prova viva da possibilidade de passagem para o "sim". É, portanto, a confirmação, a certeza, de que a escola pode se configurar como espaço de superação de si própria, a partir do momento em que ela decidir abrir suas entranhas, analisar suas práticas, refletir sobre o passado e suas chances de futuro.

\section{REFERÊNCIAS}

[1] Borges, J. A.; Borges, P.P. Matemática para alunos cegos. Revista Ciência Hoje. Disponível em: http://cienciahoje.org.br/artigo/matematica-para-alunos-cegos/. Acesso em: 28 fev. 2019.

[2] Guimarães, D. N.; Melo, D. C. F. Educação e direito: inclusão das pessoas com deficiência visual. Campos dos Goytacazes, RJ: Brasil Multicultural, 2016.

[3] Rocha, A.B.O. O papel do professor na educação inclusiva. Ensaios Pedagógicos, v.7, n.2, Jul/Dez 2017. Disponível em: file://C:/Users/Acer/Downloads/n14-artigo-1-0-Papel-do-Professor-na-Educacao-Inclusiva.pdf. Acesso em: 20 fev. 2019. 


\section{Capítulo 15}

\section{A contribuição do rádio para formação cidadã de pessoas com deficiência visual}

\section{Rosane da Silva Nunes \\ Erlane Cristhynne Felipe dos Santos}

Resumo: A formação do indivíduo envolve práticas de sociabilidade para as quais plataformas de comunicação são um campo relevante na contemporaneidade. Em se tratando de pessoas com deficiência visual, o rádio se destaca como um meio eficaz de socioeducação. Esse trabalho aborda o uso do rádio por locutores com deficiência visual. Para tanto, segue procedimentos metodológicos de natureza qualitativa, amparados nos instrumentos da pesquisa bibliográfica e entrevistas semiestruturadas. 0 estudo aponta que o rádio contribui para a formação cidadã de pessoas com deficiência visual que saem da posição de receptores e passam a emitir mensagens.

Palavras-chave: formação cidadã, comunicação radiofônica, pessoas com deficiência visual. 


\section{INTRODUÇÃO}

A unisensorialidade do rádio o torna um veículo peculiar em linguagens e narrativas, pois carrega um potencial semiológico bastante propício à interatividade e à imaginação. Não é por acaso que mesmo sendo o pioneiro na comunicação de massa, com quase um século de existência, ainda alcance consideráveis audiências em todas as faixas etárias. Trata-se de um veículo que se aproxima do público por meio da coloquialidade, da regionalização cultural e da emoção traduzidas principalmente pela performance vocal dos locutores. A voz é o principal elemento da linguagem radiofônica que, acompanhada da música, dos efeitos sonoros e até mesmo do silêncio, tecem narrativas que despertam a atenção do ouvinte (SILVA, 1999). Além disso, o veículo guarda o potencial que pertence a todos os meios de comunicação: o de canal para o exercício da cidadania, tanto do emissor quanto do receptor.

No caso do rádio, devido à relativa facilidade técnica de veiculação, o acesso à produção de conteúdos é mais simples que na televisão e bem próximo da acessibilidade da internet, fato que torna o veículo rádio o mais propenso à comunicação e mobilização populares. Em sua gênese, o rádio foi instrumento de educação, e ao longo de sua história, continua sendo um meio bastante utilizado por movimentos sociais em ações formativas de indivíduos ou grupos vulneráveis socialmente. Nas escolas, as rádios escolares são importantes instrumentos de educomunicação. Exemplo disso foram as Escolas Radiofônicas no município de Natal, experiência promovida pelo Serviço de Assistência Rural (SAR) que se tornou modelo para o Movimento de Educação de Base (MEB) em todo o Brasil (CARVALHO et al, 2009). Sendo assim, esse meio de comunicação pode ser uma ferramenta de formação cidadã e inclusão social, inclusive para pessoas com deficiência visual. É sobre a relação entre esses sujeitos e o rádio que trata o presente trabalho.

Nosso objetivo é identificar o impacto da prática radiofônica na vida de pessoas com deficiência visual, quais as possíveis contribuições nos aspectos sociais, políticos e educacionais. Salienta-se que existe ainda pouca pesquisa e literatura quanto à relevância do rádio na comunicação de tais grupos, embora o uso desse veículo possa ser mais conveniente do que o uso de outros meios de comunicação como a televisão, tendo em vista que a linguagem audiovisual deixa algumas lacunas na informação, pois em sua maioria mostra imagens sem utilizar o recurso da audiodescrição. Esse recurso midiático, seja na plataforma convencional de transmissão por ondas ou via internet, pode ser utilizado também na educação a distância de pessoas com deficiência visual. Além disso, por meio desse instrumento, a transmissão de informações factuais vem sendo gerada de forma conveniente a um público desprovido do recurso visual.

Esse trabalho, realizado em decorrência de pesquisa de campo desenvolvida na disciplina Educação Brasileira do Programa de Pós-Graduação em Educação (PPGED) na Universidade Federal do Rio Grande do Norte (UFRN), ancora-se em pesquisa de abordagem qualitativa, uma vez que trará subjetividades das interpretações das autoras acerca dos dados levantados na pesquisa bibliográfica, uma das bases metodológicas dessa pesquisa. Também apresentaremos resultados de entrevistas semiestruturadas realizadas com locutores radiofônicos na condição de deficiência visual sobre suas vivências com o rádio. Tais percepções apoiarão reflexões teóricas sobre a relação entre rádio e formação cidadã.

Por se tratar de um trabalho que aborda o potencial educativo do rádio por pessoas com deficiência visual, reflexões teóricas sobre educomunicação e educação inclusiva serão norteadoras do trabalho, bem como a historicidade da relação entre comunicação e educação no Brasil e da educação especial. Pode-se considerar, com o desenvolvimento desta pesquisa, a relevância social e científica do assunto abordado, por ser uma área de estudo com intuito de buscar instrumentos que favoreçam a inclusão social para serem aplicados no âmbito escolar, sendo um campo de prioridade da ciência e de emergência nos estudos em educação.

\section{UM BREVE HISTÓRICO DA EDUCAÇÃO DE PESSOAS COM DEFICIÊNCIA VISUAL NO BRASIL: DESAFIOS E RECURSOS ACESSÍVEIS.}

A partir da década de 1970 surgem as organizações "de" e "para" pessoa com deficiência. Segundo Santos (1995, p. 24), "[...] até os anos 80 a integração desenvolveu-se dentro de um contexto histórico em que pesaram questões como igualdade e direito de oportunidades". Isso implica dizer que começaram a surgir os movimentos de pessoas com deficiências que deram visibilidade à questão perante a sociedade, pois até então era como se esses indivíduos não existissem. Antes desse período, as pessoas com deficiência visual eram mais reservadas ao âmbito familiar. Pode-se assim dizer que aos olhos da sociedade mereciam caridade e não cidadania.

A criação da primeira instituição especializada, o Instituto Imperial de Meninos Cegos no Brasil, em 1854 hoje Instituto Benjamin Constant na cidade do Rio de Janeiro (BRASSI, 2007) foi um marco. Vale destacar 
que contribuiu para a criação desse instituto a iniciativa de um jovem cego chamado José Álvares de Azevedo, que deflagrou, em 1850, um movimento por todo o Brasil em prol das pessoas que sofriam exclusão social apenas porque não enxergavam. Com esta iniciativa alavancou-se o processo de inclusão das pessoas com deficiência visual na sociedade (BRASIL, 2016). Nesse período, o modelo de educação adotado para a pessoa cega e com baixa visão tinha no Instituto Imperial o único educandário. Fernandes (2002) corrobora a pertinente contribuição do já citado José Álvares de Azevedo, pois este brasileiro que estudou em Paris, trouxe o sistema braile para o Brasil. Com isso, o imperador Dom Pedro II, entusiasmado como o que viu, criou o referido instituto e deu início ao período da história tendo como protagonistas as pessoas cegas na história da educação no Brasil. Foi de grande impacto a criação do Instituto Benjamin Constant, pois foi o primeiro da época no qual as pessoas com deficiência visual começaram a ter educação formal. Isso foi um marco, mesmo sabendo que ainda era uma minoria a ter acesso a esse equipamento educacional. Tempos depois, as escolas começam a acolher pessoas com deficiência em salas comuns, instaura-se o processo de inclusão que até hoje está em curso.

Nessa longa trajetória histórica educacional da pessoa com deficiência visual existiram os desafios que estão diretamente relacionados ao preconceito e desconhecimento de suas condições, além das questões dos recursos utilizados por essas pessoas no processo de formação educacional, sobre o qual é imprescindível destacar que esta já tem um déficit em relação aos ditos "normais". Tendo em vista os vários fatores que dificultam a inclusão plena de tais pessoas, o preconceito figura como o maior deles. Como consequência, muitas pessoas nessa condição sofrem discriminação nas escolas, assim como em diversas esferas sociais.

Isso se explica em razão da cultura que permeia a sociedade, uma vez que somos criados para não reconhecer as diferenças, uma problemática que vem sendo tratada pela educação para os direitos humanos, que atualmente se pauta não apenas pela igualdade de direitos, mas pelo direito a serem respeitadas todas as diferenças (CANDAU, 2008). 0 preconceito vem atuando como um sentimento ou opinião arraigado que tem influenciado o comportamento humano em diversos aspectos. Uma circunstância na qual a busca pela desintegração da discriminação ao diferente representa uma ação de difícil alcance, considerando-se a necessidade de mudanças no comportamento das pessoas perante o entorno das diferenças e do desconhecido no âmbito social. Candau et al. (2012) enfatiza que os preconceitos e as discriminações encontram-se radicados nas mentalidades e no imaginário coletivo da sociedade, impregnando o cotidiano, os comportamentos, as atitudes e as práticas sociais. Para os autores:

Desintegrá-los exige um processo consciente, cuidadoso e sistemático de desnaturalização, sensibilização, reflexão e ação no plano pessoal e coletivo, que trabalhe os âmbitos cognitivo, afetivo, simbólico, cultural e político-social. [...] Somente na articulação entre práticas educativas, culturais e político-sociais é possível avançar. Trata-se de um processo complexo e de longo prazo. (CANDAU et al., p. 79).

Na condição da pessoa com deficiência, o preconceito é uma das principais barreiras enfrentadas, pois se encontra alicerçado na falta de conhecimento da deficiência em si, por ser vista como uma incapacidade que limita as pessoas a diversas esferas sociais. De acordo com Melo (2010), o desconhecimento e os estigmas formados em torno da deficiência contribuem para que essas pessoas sejam vistas como seres interpretáveis.

Além do maior desafio que é enfrentar o preconceito, existem diversas barreiras, entre elas o acesso aos dispositivos eletrônicos de altos custos, como por exemplo, o JAWS, leitor de tela que permite a pessoa com deficiência visual ter autonomia diante de um computador. Existem ferramentas que propiciam acessibilidade, tanto no que se refere ao mundo cultural quanto científico. A falta dessas ferramentas provoca o acesso restrito à informação. Esse fato ocorre em razão da necessidade de materiais adaptados, sejam estes em braile, escrita ampliada, sintetizadores de voz, áudio livros, dentre outros.

Pensando a educação em outros contextos, a realidade é a mesma, visto que a precariedade de recursos permanece. Nessa conjuntura, o rádio pode constituir um instrumento relevante na educação, por se tratar de um veículo de comunicação essencialmente falado. Desta forma, traz para o cotidiano da sociedade, assim como para a vida das pessoas com deficiência visual, grandes contribuições. Salienta-se que apesar de vários formatos midiáticos atualmente disponibilizados, o rádio ainda hoje é umas das principais fontes para que a pessoa com deficiência se mantenha informada acerca do que ocorre na sociedade, posto que muitas vezes tais pessoas não dispõem de outro veículo condizente com suas necessidades de acordo com as possibilidades existentes. 


\section{O PAPEL DOS VEÍCULOS DE COMUNICAÇÃO NA FORMAÇ̃̃O SOCIOEDUCACIONAL DO INDIVÍDUO}

Antes de abordar a questão específica da afinidade do rádio com a formação cidadã da pessoa cega, necessário é destacar a relação estreita entre comunicação e educação - seja formal ou informal, pois em tempos em que os meios de comunicação interferem tão diretamente na leitura de mundo das pessoas, como alerta Caldas (2006, p. 118), "[...] não há mais como negar a importância de pesquisas integradas entre esses dois campos de estudo [comunicação e educação]". No Brasil, o hibridismo de práticas educativas com técnicas da comunicação surgiu mais fortemente na década de 1970 (SOARES, 2011). Os debates acadêmicos acerca desses dois campos problematizaram a interdependência entre eles e, nesse contexto, foi consolidado, na década de 1990 "um novo campo do saber, absolutamente interdisciplinar e com certa autonomia em relação aos tradicionais campos da educação e da comunicação" (SOARES, 2011, p. 35). Esse novo campo epistemológico aproxima áreas que até pouco tempo eram consideradas com especificidades e finalidades distintas, possibilitando novas leituras, questionamentos, investigações e construção de saberes. Esse segmento de estudo da interface entre educação e comunicação conta com um vasto arcabouço de pesquisas (BACEGGA, 2003; CALDAS, 2006; SOARES, 2011; BALTAR, 2012 entre outros). Além destes, autores clássicos como Kaplun (1999) e Freire $(1996,1997)$ trazem importantes contribuições para o tema; o primeiro para criticidade para com os discursos da mídia e formação de uma recepção ativa e o segundo na vertente da educação dialógica.

O uso da educação dialógica, princípio definido por Freire (1967), pressupõe que para existir conhecimento é necessária uma relação social igualitária que promova práticas sociais transformadoras. As criações audiovisuais e as rádios comunitárias são exemplos de projetos criados por meio de dispositivos tecnológicos que são utilizados no processo educativo de determinado grupo social e, em grande parte, fora do âmbito escolar, no espaço cotidiano vivido, pois segundo Freire (1997) a sala de aula não é lugar exclusivo de aprendizagem e a comunicação potencializa a formação na medida em que promove a troca de conhecimentos, o que antes era apenas um fluxo informativo passa a ter uma dimensão educativa.

Para além do viés comunicativo da educação dialógica, há que se atinar para o fato de que vivenciamos hoje o que Rubim (2000) denomina Idade Mídia, uma sociedade cuja ambiência se estrutura e se fundamenta no arcabouço da comunicação midiática. Passamos por mudanças socioculturais advindas com novos modos de circulação da informação, processo que Martin-Barbero (2014) classifica como descentramento do livro como eixo de todo acesso ao saber, fazendo com a que a escola precise conviver com "saberes-sem-lugar-próprio". 0 autor considera que esse processo não significa o desaparecimento do espaço-tempo-escolar, mas alerta que "[...] as condições de existência desse tempo se veem transformadas porque os saberes que nela se ensinam encontram-se atravessados por saberes do ambiente telecomunicativo" (MARTIN-BARBERO, 2014, p.83), referindo-se aos conteúdos gerados através das plataformas de telecomunicação, rádio, televisão e telefonia. Portanto, os saberes mediados pelos veículos de comunicação constituem hoje um lugar de formação, inclusive no que tange a assuntos relacionados aos Direitos Humanos, entendido nesse trabalho como tangencial à inclusão de pessoas com deficiência visual, tanto na escola como no mundo do trabalho - segundo o relatório Mídia e Direitos Humanos (ANDI, 2006) questões de diversidade ocupam o segundo lugar na abordagem de Direitos Humanos feita pela imprensa brasileira.

No entanto, o potencial socioeducativo dos veículos de comunicação não reside somente no acesso às informações midiáticas, mas também na possibilidade de gerar conteúdos. No caso do rádio, a emissão de mensagens se torna ideal para as pessoas com deficiência visual, já que este meio é unisensorialmente auditivo. Ademais, o rádio possui expressiva popularidade e alcance geográfico. As características desse veículo estão representadas, principalmente, pelo tipo de linguagem utilizada, pela mobilidade que permite tanto ao ouvinte como ao emissor, pelo baixo custo investido na transmissão e na recepção. No tocante à linguagem, destaque-se a oralidade mediatizada (Silva, 1999), cuja mensagem é transmitida através da linguagem da fala acrescida dos demais elementos da linguagem radiofônica - música, silêncio e ruídos - e mediada por um meio de comunicação eletrônico, permitindo que o público possa decodificála sem dificuldade, uma vez que a linguagem do rádio possibilita a aplicação da performance vocal sobre a mensagem textual, formando um texto verbal-oral que gera identificação com o ouvinte. Esta é uma vantagem perante o meio impresso e também uma facilidade frente à televisão, a qual várias vezes se utiliza da escrita para complementar a mensagem, inclusive com legenda de entrevistados e apresentação de dados. A coloquialidade inerente à linguagem radiofônica, responsável pela espontaneidade que cativa os ouvintes, é também um ponto forte de atração às pessoas cegas, que sentem na voz a aproximação necessária à identificação com o locutor e por consequência, ao acolhimento da mensagem emitida. 
Godoy (2003), em pesquisa sobre a relação entre o rádio e o deficiente visual, constatou que as características que esse público mais admira no locutor são a espontaneidade, a simplicidade e a forma simpática e sincera de tratar o ouvinte. 0 uso correto de técnicas de redação radiofônica, como a ordem direta nas frases e períodos curtos, também foi apontado pelas pessoas com deficiência visual como recursos que facilitam o entendimento da mensagem. Outro aspecto relevante apontado na pesquisa é que os demais veículos discriminam quem pode enxergar, conforme relato de um dos entrevistados pela pesquisadora: "[...] é discriminação quando dizem ligue para o número em sua tela. No rádio a pessoa fala e repete a informação... para mim não tem nada que o substitua" (GODOY, 2003, p. 8). Uma característica valorizada por muitos no rádio é servir como companhia, sendo este um atributo indicado pelos entrevistados também: "eu concordo com a ideia de que o rádio chega mais perto das pessoas, através do rádio você consegue transmitir muitas coisas para as pessoas, mais que a televisão" (GODOY, 2003, p, 9). Essa sensação de proximidade, de companhia, dá-se tanto pelas características supracitadas do veículo como pelo potencial do som de mediador entre o mundo material e o invisível, fazendo com que os conteúdos transmitidos pela oralidade mediatizada do rádio tenham uma carga emocional, como frisa Kaseker (2012, p. 33), "[...] uma característica bastante comum é associação da escuta a condição de solidão. 0 rádio é companheiro e conecta o ouvinte a vozes familiares que sempre estarão por perto".

Com base nas considerações até aqui destacadas, nota-se que o rádio pode ser largamente utilizado por pessoas cegas, tanto na qualidade de ouvintes como de locutores. É sobre esse último segmento que trata o recorte empírico desse trabalho, o qual iremos apresentar a seguir.

\section{PERCEPÇÕES DE PESSOAS COM DEFICIÊNCIA VISUAL SOBRE O USO DO RÁDIO NA FORMAÇÃO CIDADÃ}

Considerando que o trabalho aborda questões referentes ao rádio e a pessoa com deficiência visual, é imprescindível saber a opinião de tais pessoas a respeito desse veículo de informação e comunicação. Para tanto, trazemos percepções de dois locutores, por meio de entrevistas realizadas em maio de 2016. A amostragem não tem suporte quantitativo, pois optamos por uma abordagem qualitativa, base maior da pesquisa social. 0 instrumento metodológico foi questionário semiestruturado, que apontou para quatro pontos-chave: o que o rádio representa para o entrevistado, na condição de ouvinte e na condição de locutor; como se tornou locutor; quais as dificuldades enfrentadas e qual a influência da locução radiofônica para a formação cidadã. As entrevistas, com cerca de 60 minutos cada, foram transcritas e analisadas segundo categorias previamente definidas: representação do rádio; historicidade - trajetória de vida como locutor; dificuldades inerentes à deficiência visual, influência do veículo para formação social. Foram entrevistados dois locutores ${ }^{33}$, sobre os quais discorremos a seguir.

José Veríssimo dos Santos, 54 anos, é divorciado, cursou o ensino médio e reside em Juazeiro do Norte, Ceará. Possui cegueira congênita, é ouvinte de rádio desde os nove anos de idade e sempre gostou de ouvir programas de forró. Foi com eles que aprendeu a tocar sanfona, sozinho, apenas ouvindo o rádio. É locutor de rádio há 17 anos, começou na rádio comunitária Líder FM, em Juazeiro do Norte e atualmente trabalha na Rádio Verde Vale AM, localizada no mesmo município e detentora de larga audiência na região. É fundador e presidente da Associação de Pessoas com Deficiência Visual do Cariri. A entrevista com Veríssimo foi realizada presencialmente, em 27 de maio de 2016.

Humberto Pires do Carmo, 49 anos, é solteiro, cursou até o ensino médio e reside em Salvador, Bahia. Sua condição de deficiência visual é congênita, causada por glaucoma, o que o fez com cinco anos perder a visão por completo. É ouvinte de rádio desde os cinco anos de idade e sempre gostou de ouvir programas de notícias e de música sertaneja, mas gostava de Jazz e Blues também, aproximando-se depois do Rock e do estilo Pop. É locutor de rádio há dois anos, militante e ativista do Movimento Visibilidade Cegos Brasil (VCB), que defende a efetivação dos direitos das pessoas com deficiência, em especial das que possuem deficiência visual. Esse movimento fundou uma rádio em $2014^{34}$.

${ }^{33}$ Os entrevistados assinaram termo de autorização de uso de depoimentos e imagens.

${ }^{34}$ Disponível em www.visibilidadecegosbrasil.com.br. Acesso em 17 jun 2016. 
Indagados sobre o que o rádio representa para si na condição de ouvinte, Veríssimo é taxativo: "Representa tudo. Ele foi e continua sendo meu companheiro". Sua resposta reafirma o caráter educativo não formal do rádio, além de seu potencial de fazer companhia aos ouvintes, como frisou Kaseker (2012). Já Humberto usou um tom poético, mas sucinto, dizendo: "Um veículo maravilhoso de comunicação. É a diferença entre ter o mundo ou não ter." Essa opinião sobre o rádio vai ao encontro do pensamento de Godoy (2002), para a qual os veículos de comunicação podem manter informados todos dos cidadãos de forma crítica, incluindo-os na sociedade. Muito embora em diversos momentos esse papel social deixe algumas lacunas - como em diversas situações em que as pessoas com deficiência visual se deparam com um noticiário posto na televisão, não permitindo uma compreensão exata do que está acontecendo.

Sobre o sentido do rádio para os entrevistados, Veríssimo destaca o apoio desse veículo na promoção de seu trabalho como músico, pois além de sanfoneiro, é também compositor e cantor, tendo gravado um CD: "em primeiro lugar eu sou artista e sem o rádio, o artista não vai a lugar nenhum, é ele quem divulga nosso trabalho". Nessa resposta, o entrevistado aponta para uma característica do veículo ainda não considerada na pesquisa, o potencial de afirmação social que o meio de comunicação dá ao locutor e, tendo esse deficiência visual, tal exposição pode ajudá-lo a superar barreiras e firmá-lo como cidadão que tem uma profissão, no caso, a de músico. O locutor Humberto destaca que também é músico, sanfoneiro, tecladista, compositor e cantor. Frisou sobre a importância do rádio para o seu trabalho como locutor, dizendo: "É uma forma de expressão que não tem barreiras".

Conhecer a forma de ingresso na profissão de locutor é importante para compreender quais os possíveis canais de acesso da pessoa com deficiência visual em um mundo marcado pela exclusão. No caso de Veríssimo, a porta para esse mundo foi a música. Começou tocando em bandas de forró, em seguida gravou seu primeiro CD. Desse modo veio sua proximidade com os bastidores do rádio e conseguiu liderar um programa musical em uma rádio comunitária. Notamos aqui a importância do acesso à arte e cultura para afirmação da pessoa, pois foi através dela que uma pessoa na condição de deficiência chegou à profissão de radialista. Para Humberto, tendo em vista o movimento VCB, surgiu a necessidade de se criar um espaço virtual de interação para tratar de assuntos do interesse deste público. Como afirma Humberto, o movimento "precisava de um locutor que tivesse coragem de dizer o que muitos locutores não poderiam jamais falar... eu me coloquei na posição de voluntário e deu certo."

Quanto às dificuldades enfrentadas para exercer a profissão, Veríssimo afirmou que não possuía nenhuma dificuldade. Já Humberto enfatizou que os softwares mais novos de rádio não permitem acesso pleno à pessoa com deficiência visual. Questionamos o porquê dessa falta de acessibilidade e ele prontamente respondeu:

As mais modernas ferramentas de produção de rádio que funcionam no computador, elas possuem cronômetro para que as inserções dos comerciais aconteçam na hora exata e essa inserção já gera automaticamente os custos. Todo o sistema de gerenciamento de uma rádio, desde os discos que a rádio toca até o holerite que paga as pessoas... 0 sistema de cobrança de direitos autorais, tudo isso é gerenciado por um só programa. Esse programa é inacessível. Eu só posso dizer da seguinte forma: a rádio, desde a discoteca até sair no pagamento do presidente da rádio é automatizado. É baseado em cálculos dentro do próprio programa. E esse programa é inacessível. Assim como os códex são inacessíveis, também o transmissor de streaming ${ }^{35}$ é inacessível. Tudo isso é inacessível, nos novos programas, nas novas plataformas. Enfim, as novas plataformas de transmissão de rádio no computador, quer seja rádio $\mathrm{FM}$ ou rádio $\mathrm{WEB}$, são plataformas totalmente inacessíveis para a pessoa com deficiência visual. Por essa razão usamos as ferramentas antigas, tendo em vista que as atuais são inacessíveis. E até mesmo essas antigas são parcialmente acessíveis.

Cabe destacar que Veríssimo é apenas locutor, não faz uso das ferramentas radiofônicas. Já Humberto Pires, é locutor e operador de mesa, tanto faz a locução como também opera diretamente com as ferramentas, tendo, portanto, maior vivência nessa área para expressar sua opinião quanto a acessibilidade das mesmas.

\footnotetext{
35 Forma de transmissão de som e imagem que dispensa efetuar download, a transmissão ao usuário é direta.
} 
Por fim, indagados sobre qual a influência do rádio para a formação cidadã, Veríssimo apontou que foi o respeito adquirido ao tornar-se locutor:

Antes de eu trabalhar no rádio, era muito desrespeitado por algumas pessoas que me tratavam por cego. Primeiro eu fico pensando: eu não sou "cego", pois os "cegos" pra mim são aquelas pessoas que estão vendo uma coisa errada e não procuram fazer de forma correta; segundo, porque para se fazer determinadas coisas, mesmo sem estar vendo nada, eu faço. Como por exemplo: trocar uma tomada, mexer em eletricidade... Sei como colocar um cano d'água, subir num telhado para consertar uma goteira; eu sei as ruas, as lojas... Diante disso, como vou me colocar como uma pessoa "cega"? E frente a isso o rádio me trouxe esse respeito, porque hoje as pessoas me consideram por Veríssimo, quando não sabem o meu nome, me chamam por o radialista, o sanfoneiro... Mas ninguém mais me chama de cego não. Isso foi depois que eu comecei a trabalhar no rádio. Por isso que o rádio pra mim é tudo.

Na fala de Veríssimo, é possível identificar o pilar do discurso inerente aos direitos humanos: "o respeito ao outro." Foi com o rádio que ele obteve esse direito de ser respeitado pelo que se é. No caso de Humberto, destacou: "Tem toda influência para minha formação de cidadão... me tornei uma pessoa mais consciente da cidadania e dos seus reflexos sobre a sociedade, depois que me tornei um locutor de rádio."

Com base nas percepções dos entrevistados, podemos inferir que o rádio representa para a pessoa com deficiência visual a possibilidade de inclusão nas relações de sociabilidade, fato que por si só, já denota o potencial socioeducacional dessa plataforma de comunicação.

\section{CONSIDERAÇÕES FINAIS}

Na condição da pessoa com deficiência o preconceito é uma das principais barreiras enfrentadas, pois se encontra alicerçado na falta de conhecimento, por ser vista como uma incapacidade que limita as pessoas a diversas esferas sociais. De acordo com Melo (2010), o desconhecimento e os estigmas formados em torno da deficiência, contribuem para que essas pessoas sejam vistas como seres interpretáveis. Além do maior desafio que é enfrentar o preconceito, existem diversas barreiras, entre elas o acesso aos dispositivos eletrônicos de altos custos. Existem ferramentas que propiciam acessibilidade, tanto no que se refere ao mundo cultural quanto científico. A falta desses dispositivos provoca o acesso restrito à informação. Esse fato ocorre em razão da necessidade de materiais adaptados, sejam estes em braile, escrita ampliada, sintetizadores de voz, áudio livros, dentre outros.

Pensando a educação em outros contextos, a realidade é a mesma, visto que a precariedade de recursos permanece. Nessa conjuntura, o rádio pode constituir um instrumento relevante na educação, por se tratar de um veículo de comunicação essencialmente falado. Desta forma, traz para o cotidiano da sociedade, assim como para a vida das pessoas com deficiência visual, grandes contribuições. Salienta-se que apesar de vários formatos midiáticos disponibilizados, o rádio ainda hoje é umas das principais fontes para que a pessoa com deficiência se mantenha informada acerca do que ocorre na sociedade, posto que muitas vezes tais pessoas não dispõem de outro veículo condizente com suas necessidades de acordo com as possibilidades existentes.

Buscamos trabalhar os pontos nodais entre esferas importantes na tessitura complexa dos debates em torno da educação inclusiva, ao aproximar a temática da educação não formal proporcionada pelo acesso a um veículo de comunicação de caráter fortemente popular que é o rádio. Portanto, os elementos teóricos e empíricos aqui apresentados lançam luz sobre questões relativas aos direitos humanos e a importância do exercício destes para a formação social do indivíduo, tendo como fio condutor desse processo formativo a prática da comunicação midiática, a qual ingressou definitivamente no campo da educação desde o surgimento da sociedade da informação.

As percepções dos entrevistados corroboram a forte interface entre comunicação e educação ao apontar para o viés formativo desse veículo para os locutores com deficiência visual. Entendemos que os resultados obtidos constituem um recorte delimitado da questão e que, devido a ainda baixa produção científica sobre o uso do rádio por pessoas com deficiência visual, o trabalho pode contribuir para a construção de conhecimento nessa área. No entanto, há muito o que se vislumbrar nessa relação entre educação inclusiva, comunicação e cidadania. Esse trabalho oferece uma contribuição ao trabalho realizado dentro e fora da academia no sentido de fortalecer essa tríade. 


\section{REFERÊNCIAS}

[1] Agência Nacional Pelos Direitos da Infância. Mídia e direitos humanos. Brasília: Andi, Secretaria Especial dos Direitos Humanos, Unesco, 2006. 372 p.

[2] Baccega, Maria Aparecida. Televisão e escola: aproximações e distanciamentos. In: Congresso brasileiro de Ciências da Comunicação, 25., 2002, Salvador, Anais... Salvador, 2002. p 1-22.

[3] Baltar, Marcos. Rádio escolar: uma experiência de letramento midiático. São Paulo, Cortez, 2012. 163 p.

[4] Brasil. Ministério da Educação. Instituto Benjamin Constant: o IBC. 2016. Disponível em: <http://www.ibc.gov.br/o-ibc>. Acesso em: 05 mar. 2017.

[5] Brassi, Karla Bertacini. O papel do professor comum diante da cegueira. 2007. 52 f. Monografia (Graduação) - Curso de Pedagogia, Centro de Educação e Ciências Humanas, Universidade Federal de São Carlos, São

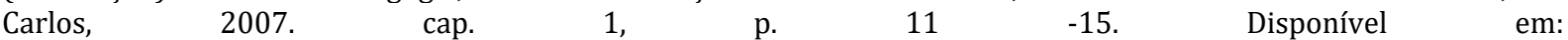
<http://www.ufscar.br/ pedagogia/novo/files/tcc/tcc_turma_2004/248967.pdf>. Acesso em: 09 jun. 2016.

[6] Caldas, Graça. Mídia, escola e leitura crítica do mundo. Revista Educação e Sociedade. 2006, v. 27, n. 94, p. 117-130, jan./abr. 2006

[7] Candau, Vera Maria. Direitos humanos, educação e interculturalidade: as tensões entre igualdade e diferença. Revista Brasileira da Educação [online]. Rio de Janeiro, v. 13, n.37, p. 45-56, jan./abr. 2008

[8] Candau, Vera Maria (coord.). Somos todos iguais? Escola, discriminação e educação em direitos humanos. Rio de Janeiro: Lamparina. 2012. p. 71-80.

[9] Carvalho, Maria Araújo Duarte. et al. Escolas radiofônicas de Natal: uma história construída por muitos. Brasília: Liber Livro Editora, 2009. 154 p.

[10] Fernandes, Carlos (Comp.). Só biografias. 2002. Disponível em: <http://www.dec.ufcg.edu.br/biografias/index.html?submit=Home+Page>. Acesso em: 16 jun. 2016.

[11] Freire, Paulo. Educação como prática da liberdade. Rio de Janeiro: Paz e Terra, 1967. 157 p.

[12] __. Paulo. Pedagogia da autonomia: saberes necessários à prática educativa. São Paulo: Paz e Terra, 1996. $148 \mathrm{p}$.

[13] _. Paulo. Pedagogia da esperança: um reencontro com a pedagogia do oprimido. São Paulo: Paz e Terra,1997.245 p.

[14] Godoy, Elisangela Ribas. Rádio: o informante dos que não enxergam. 2002. 107 f. Dissertação (Mestrado) Curso de Engenharia de Produção, Programa de Pós-Graduação em Engenharia de Produção da Universidade de Santa Catarina, Universidade Federal de Santa Catarina, Florianópolis, 2002. cap. 1. p.11-21. Disponível em: <https://repositorio.ufsc.br/bitstream/handle/123456789/87212/227678.pdf?sequence=1>. Acesso em: 21 maio 2016.

[15] ___. Elisâgela Ribas. Rádio: um companheiro do cego. In: Congresso de Ciências da Comunicação, 26., 2003, Anais... Belo Horizonte, MG, 2003.

[16] Kaplun, Mario. Processos educativos e canais de comunicação. 1999. Revista Comunicação e Educação, São Paulo, v. 14, n. 1, p. 68-75, jan./abr. 1999.

[17] Kaseker, Monica Panis. Modos de ouvir: a escuta radiofônica ao longo de três gerações. Curitiba: Champagnat, 2012. 299 p.

[18] Martin-Barbero, Jesus. A comunicação na educação. São Paulo: Contexto, 2014. 155 p.

[19] Melo, F. R. L. V. Interações com pessoas com deficiência : algumas orientações básicas. Natal, RN: Comissão Permanente de Apoio a Estudantes com Necessidades Educacionais Especiais, 2010.p. 1- 9.

[20] Rubim, Antônio Albino Canelas. Comunicação e Política. São Paulo: Hacker, 2000.

[21] Santos, M. P. Perspectiva histórica do movimento integracionista na Europa. Revista Brasileira de Educação Especial, n.3. Piracicaba: Unimep, 1995. p. 21-29, mai./ago. 1995.

[22] Silva, Júlia Lúcia de Oliveira Albano da. Rádio: oralidade mediatizada. São Paulo: Annablume, 1999. 116 p.

[23] Soares, Raquel Paiva Araújo. A mídia como educadora coletiva: cidadania ou apatia? In: Melo, José Marques. et al. Educomídia, alavanda da cidadania. São Bernardo do Campo: Cátedra Unesco; Universidade Metodista de São Paulo, 2006. 


\section{Capítulo 16}

\section{Classe hospitalar: Promoção da condição humana}

\section{Aparecida Ramazotti de Camargo}

Gláucia Pereira Lima Joaquim Braga

Mario César Alves Ferreira

Resumo: Esse estudo apresenta uma análise dos resultados escolares referentes à aprovação ou reprovação dos alunos atendidos pelo Serviço de Atendimento a Rede de Escolarização Hospitalar (SAREH) no Hospital Universitário Regional do Norte do Paraná (HURNP), Londrina, a partir de um levantamento de dados do ano 2014. Embora a internação, na maioria dos casos costume configurar-se como um período transitório, pode alterar significativamente as atividades cotidianas. Em relação à escolarização essas alterações vão desde o afastamento das atividades pedagógicas e prejuízo no desenvolvimento cognitivo pela não frequência às aulas até a perda do contato direto com seus pares. Na presente pesquisa foi utilizada a metodologia quantitativa, foi verificada a quantidade de atendimentos oferecidos a alunos internados por um período igual ou superior a sete dias, cruzando em seguida esses dados com os dados do Sistema Estadual de Registro Escolar - SERE, verificando a aprovação ou não desses alunos no ano letivo referido. Verificou-se que durante o ano letivo de 2014 foram atendidos com aulas um total de 415 alunos. Desse total 54 estiveram internados por um período igual ou superior a sete dias e $79,63 \%$ foram aprovados para a série seguinte ao final do período letivo. Foi possível concluir que a atuação do SAREH foi importante para os resultados obtidos pelos alunos. Os atendimentos pedagógicos durante a internação contribuíram para a apropriação de conteúdos e atuaram também como incentivo para sua volta à escola ao propiciar-lhes as condições para retomarem seus estudos sem prejuízo, como comprovou o índice de aprovação obtida por eles.

Palavras-chave: Atendimento educacional hospitalar. Sareh. Educação inclusiva. 


\section{INTRODUÇÃO}

A educação é a provedora das ferramentas que os indivíduos necessitam para compreender o mundo a sua volta, as mudanças ocorridas com o mesmo tanto no aspecto social quanto profissional, desse modo a escola e a educação estão intimamente ligadas à evolução do ser humano em suas potencialidades através da apropriação dos conhecimentos historicamente produzidos pela humanidade. Segundo a Organização Mundial da Saúde - OMS (1946) a saúde é o completo estado de bem estar físico, mental e social do indivíduo, e não apenas a inexistência de enfermidades, assim sendo a manutenção da saúde está também ligada à educação.

Quando alguém em idade escolar passa por internação hospitalar é privado do acesso à educação na escola, em vista disso os serviços de educação dentro dos hospitais como o Serviço de Atendimento à Rede de Escolarização Hospitalar - SAREH vem de encontro à necessidade desse indivíduo de continuar com seus estudos ao ofertar a possibilidade do atendimento escolar dentro da unidade de saúde.

Esse estudo apresenta uma análise dos resultados escolares referentes à aprovação ou reprovação dos alunos atendidos pelo SAREH no Hospital Universitário Regional do Norte do Paraná (HURNP), Londrina, a partir de um levantamento de dados do ano 2014. Para tanto foram analisadas as situações dos alunos que estiveram internados e, portanto afastados da escola, por sete dias ou mais. Levou-se em consideração que um período prolongado de afastamento justifica de forma mais contundente a relevância da classe hospitalar.

No desenvolvimento da análise, através de pesquisa, verificou-se que durante o ano letivo de 2014 foram atendidos com aulas um total de 415 alunos. Desse total 54 estiveram internados por um período igual ou superior a sete dias o que perfaz um percentual de $13,01 \%$ dos atendimentos com aulas considerando-se apenas os alunos do ensino regular.

\section{OBJETIVOS}

- Verificar o resultado final dos alunos que em 2014 ficaram afastados da escola por um período significativo devido à internação hospitalar e que receberam atendimento escolar pelo SAREH;

- Qualificar o trabalho do SAREH e produzir subsídio para incrementar o Plano Pedagógico Hospitalar- PPH.

\section{MARCO TEÓRICO}

A educação hospitalar está no rol das conquistas sociais do século XX. Desde a primeira classe na Escola Hospital Menino Jesus do Rio de Janeiro em 1950 até os dias de hoje muito se caminhou, mas o caminho é ainda bastante longo no intuito de garantir o acesso à educação para todos em qualquer circunstância. $\mathrm{Na}$ intenção de atingir de forma mais eficaz tal atendimento e buscando garantir a sua legalidade, na última década do século passado, com a aprovação da nova Lei de Diretrizes e Bases da Educação Nacional (LDBEN), também os estados e municípios elaboraram alguns dispositivos legais que tratam do assunto. Segundo o portal Dia a Dia Educação (2015) do Governo do Paraná no Estado a base legal do SAREH está assim constituída:

Constituição Federal de 1988 - Institui o Estado Democrático Brasileiro.

Deliberação do Conselho Estadual de Educação no 02/03 - Fixa normas para a Educação Especial para o Sistema de Ensino de Estado do Paraná.

Instrução no 006/2008 - Sued/Seed - Estabelece procedimentos para a implantação e funcionamento do Serviço de Atendimento à Rede de Escolarização Hospitalar.

Instrução no 016/2012 - Seed/Sued - Estabelece procedimentos para a implantação e funcionamento do Serviço de Atendimento à Rede de Escolarização Hospitalar.

Lei de Diretrizes e Bases da Educação Nacional n. 9.394/96 - Estabelece as Diretrizes e Bases da Educação Nacional.

Lei n. 8.069/90 - Estatuto da Criança e do Adolescente de 1990.

Lei n. 6.202/75 - Atribui à estudante em estado de gestação o regime de exercícios domiciliares instituído pela Lei 1.044/69. 
Lei n. 1.044/69 - Dispõe sobre tratamento excepcional para os alunos portadores das afecções.

Parecer no 17/2001 do Conselho Nacional de Educação - Estabelece as Diretrizes Nacionais para a Educação Especial na Educação Básica.

Resolução no 2527/2007 - Institui o Serviço de Atendimento à Rede de Escolarização Hospitalar - Sareh no Estado do Paraná.

Resolução n. 01/02 do Conselho Nacional de Educação/CP - Institui as Diretrizes Curriculares Nacionais para a Formação de Professores da Educação Básica.

Resolução no 02/01 do Conselho Nacional de Educação/CEB - Institui as Diretrizes Nacionais para a Educação Especial na Educação Básica.

Resolução no 41/95 do Conselho Nacional de Defesa dos Direitos da Criança e do Adolescente - Direitos da Criança e do Adolescente Hospitalizados.

Como consta da Resoluçãodo Conselho Nacional de Educação, Câmara de Educação Básica (CNE/CEB) no 02, de 11 de setembro de 2001 em seu artigo 13:

os sistemas de ensino, mediante ação integrada com os sistemas de saúde, devem organizar $o$ atendimento educacional especializado a alunos impossibilitados de frequentar as aulas em razão de tratamento de saúde que implique internação hospitalar, atendimento ambulatorial ou permanência prolongada em domicílio.

Presente em 18 hospitais, o SAREH, é considerado como se atendesse a todo o Paraná já que está presente nos maiores hospitais regionais, entretanto essa oferta ainda é pequena em vista da necessidade de se garantir o acesso à educação para todos. 0 ideal seria a existência de equipes itinerantes de professores, a presença de equipes fixas nos demais hospitais e por fim a possibilidade da escolha por parte dos pais de enviar seus filhos para hospitais atendidos pela rede do SAREH em casos de internação prolongada.

O Hospital Universitário Regional do Norte do Paraná em Londrina é um hospital público de grande porte, classificado como nível terciário por atender a uma macrorregião com serviços ambulatoriais e hospitalares especializados e de alta complexidade. Atua em prestação de serviço de assistência à saúde em praticamente todas as especialidades médicas, formação de recursos humanos, educação continuada, pesquisa e desenvolvimento tecnológico, cooperação técnica e científica com a rede de serviços. (UEL, 2015)

É Centro de Referência Regional para o SUS. Atende pacientes de cerca de 250 municípios do Paraná e de mais de 100 cidades de outros Estados. Realiza atendimentos de alta complexidade nas áreas de Tratamento de Queimados, Transplante de Medula Óssea, Ortopedia, Gestantes de Alto Risco e UTIs (Adultos, Pediátrica e Neonatal). (UEL, 2015)

Segundo a interface voltada para o público (UEL, 2015) o HURNP tem como missão "Prestar assistência integral à saúde, com excelência e qualidade, participando na prática do ensino, pesquisa e extensão, integrados ao Sistema Único de Saúde, contribuindo para melhoria da qualidade de vida da população". É um Hospital Estratégico para o SUS por se tratar do único hospital público de grande porte no norte do Paraná. (UEL, 2015)

0 atendimento pedagógico ocorre através de convênio entre a Secretaria Municipal, a Secretaria de Estado de Educação (SEED) e a Universidade Estadual de Londrina (UEL). As secretarias de educação mantêm o serviço como um programa especial e disponibilizam os professores e pedagoga para atuarem no hospital, que por sua vez cede o local e material de uso diário, bem como um computador e linha telefônica como sua parte no convênio. 0 paradigma é o da inclusão e a via de consecução é a do cuidado integral.

Crianças e adolescentes ou jovens enfermos e afastados da escola, em consequência dessa condição, têm na classe hospitalar um porto seguro, uma forma de manterem-se vinculados ao mundo exterior e além da doença. Como diz Taam (2004, p.139): "No ambiente hospitalar, emoções intensas e desorganizadas impregnam o ambiente, afetando profundamente o comportamento e a disposição dos pequenos pacientes, de seus acompanhantes e da equipe médico-hospitalar".

Embora a internação, na maioria dos casos costume configurar-se como um período transitório, pode alterar significativamente as atividades cotidianas. Em relação à escolarização essas alterações vão desde o afastamento das atividades pedagógicas e prejuízo no desenvolvimento cognitivo pela não frequência às aulas até a perda do contato direto com seus pares. Ao voltar após um período significativo de 
afastamento o aluno precisa refazer seus vínculos, dar explicações e acompanhar a turma que não deixou de vivenciar o processo escolar e nem de conviver diariamente. Juntando-se à debilidade física que normalmente acompanha o processo da doença e do convalescer há que se enfrentar ainda a defasagem de conteúdos e processos.

Atualmente a tecnologia oferece muitas oportunidades de manutenção de contato e os alunos são grandes usuários destas. Mesmo no hospital, desde que suas condições permitam, estão em contato virtual permanente com amigos e familiares através de celulares e computadores. Entretanto mesmo utilizando tal aparato ele não é suficiente, uma vez que o conteúdo escolar e os procedimentos metodológicos não podem ser construídos ou apropriados de forma satisfatória e significativa sem a mediação de um profissional capacitado para tal.

O papel do professor no âmbito hospitalar reveste-se ainda de um aspecto subjetivo. É um encontro pessoal. Em seus atendimentos no HURNP os professores e a pedagoga vão até as enfermarias e atendem o aluno no próprio leito e sua família nas unidades. Antes das aulas há que se estabelecer um contato empático que predisponha o aluno a realizar as atividades e seus familiares ou acompanhantes a perceberem que estas fazem parte de uma preocupação e cuidado com seus filhos ou pupilos. A primeira impressão pode ser de sobrecarga e muitos pais ou responsáveis podem querer poupá-los. Vencer essa resistência inicial quando ocorre, e promover aprendizagens significativas faz parte da dinâmica diária da equipe que atua no hospital.

Superar o medo decorrente da internação e da doença e o estresse da condição enferma são contribuições da educação hospitalar. Nas palavras de Taam (2004, p.142):

outro aspecto a ser considerado, no caso da educação da criança hospitalizada, é o caráter contagioso das emoções. A emoção define a eficiência postural, a tonicidade muscular, a qualidade expressiva, a plasticidade dos gestos, sendo, portanto, visível; por ser visível, é captada pelo outro, que sofre um efeito de contágio. [...] Se o professor através da ação pedagógica afetar positivamente as emoções das crianças e dos adultos que a rodeiam obterá resultados mais efetivos do que se centrar sua ação exclusivamente na criança.

No HURNP a forma de atendimento dada pelos professores acontece diretamente nas enfermarias de internação, no próprio leito, sempre de forma individualizada tendo em vista a complexidade dos diagnósticos e especificidade do hospital. Realizam intervenções a partir dos conteúdos escolares sem perder de vista o ser humano que está à sua frente, em uma situação diversa da escola, onde nem sempre o aluno pode ter contato com material pedagógico convencional como livros e cadernos. Dessa forma além de atender aos pressupostos pedagógicos específicos vinculados ao currículo, toda ação pedagógica no hospital orienta-se pela condição de enfermidade e internação conforme Ceccim (2007, p. 35)

as necessidades educacionais a serem atendidas pelas classes hospitalares correspondem ao restabelecimento de ligações com a vida em casa e na escola (como no cotidiano e com colegas); realização da mediação didático-educativa do desenvolvimento; promoção da maior segurança aos pais e às aprendizagens complexas; e, finalmente, oportunidade à manutenção ou recuperação ou, ainda, ao início dos vínculos com a escolaridade.

0 atendimento da forma como é praticado agrega ainda uma maior possibilidade de retomada de conteúdos e conhecimentos em que os alunos/pacientes apresentam dificuldades ou falta de prérequisitos já que ocorrem de forma individual.

\section{METODOLOGIA}

Na presente pesquisa foi utilizada a metodologia quantitativa, desse modo foi verificada a quantidade de atendimentos oferecidos a alunos internados por um período igual ou superior a sete dias, cruzando em seguida esses dados com os do Sistema Estadual de Registro Escolar - SERE, verificando a aprovação ou não desses alunos no ano letivo supracitado. Assim sendo a seguir tem se os passos detalhados da metodologia:

- $\quad$ Levantamento dos atendimentos efetuados no ano de 2014 pelo SAREH no HURNP;

- Verificação de quais e quantos alunos receberam atendimentos e ficaram internados por sete dias ou mais; 
- $\quad$ Pesquisa no SERE por meio eletrônico verificando se esses alunos atendidos pelo SAREH obtiveram sucesso na conclusão do ano letivo;

- $\quad$ Caso o aluno não constasse no Sistema a verificação deveria ser feita a partir de contato via telefone diretamente com as escolas desses alunos.

- $\quad$ Análise dos resultados e conclusões.

No total geral, foram realizados 2262 atendimentos com aulas para 415 alunos. Destes, aqueles que ficaram por um período superior a sete dias hospitalizados e fazem parte deste este estudo foram 54 alunos.

\section{RESULTADOS E DISCUSSÕES}

Como resultado, visando a um detalhamento das situações finais apresentadas, a partir dos dados coletados elaborou-se a Tabela 1 demonstrativa que dá conta de expor a quantidade de alunos reprovados ou aprovados para a série seguinte.

Tabela 1 - Resultados finais dos alunos atendidos pelo SAREH em 2014 com internação igual ou superior a sete dias

\begin{tabular}{|c|c|c|c|}
\hline \multirow{2}{*}{ PERÍODOS } & QUANTIDADE & \multicolumn{2}{c|}{ RESULTADOS } \\
& DE ALUNOS & APROVADOS & REPROVADOS \\
\hline 07 a 10 dias & 15 & 12 & 3 \\
\hline 11 a 20 dias & 14 & 12 & 2 \\
\hline 21 a 30 dias & 10 & 7 & 3 \\
\hline Mais de 30 dias & 15 & 12 & 3 \\
\hline TOTAL & 54 & 43 & 11 \\
\hline
\end{tabular}

Fonte: Dados organizados pelos autores com base no SERE-Sistema Estadual de Registro Escolar e contato telefônico com as escolas

De posse das informações levantadas foi possível determinar as seguintes discussões.

A maioria dos alunos não foi prejudicada em seu resultado final pela situação de enfermidade já que $79,63 \%$ deles foram aprovados para a próxima etapa, provavelmente esse sucesso tem ligação com a intervenção do SAREH durante o período que o aluno esteve internado.

A escola e o sistema educacional necessitam melhorar o acompanhamento dos alunos que ficaram afastados da sala de aula por conta de enfermidades como evidenciam dois casos de alunos que reprovaram pela terceira vez. Já que, o aluno se mantém na escola mesmo que não alcance o sucesso enquanto a escola não foi capaz de atender as necessidades desse aluno afim do mesmo atingir a promoção de série. Percebe-se uma lacuna no sistema educacional quando não propicia a busca ativa do aluno após a alta hospitalar para retorno às aulas ou ainda nas dificuldades para a oferta efetiva dos atendimentos domiciliares. Percebe-se muitas vezes que há desconhecimento por parte da sociedade, e também da comunidade escolar, acerca desse direito dos alunos de receber atendimento domiciliar acarretando prejuízos tanto a estes quanto à educação que vê comprometida a sua função emancipadora. Esse desconhecimento acarreta por um lado a não-oferta e por outro a não-procura.

Destacamos a relevância do SAREH ainda quando consegue significar o ato educativo e contribui para a reinserção de jovens que estão fora do sistema formal de ensino. Após conquistar o paciente e transformálo em aluno no hospital houve três casos de reinserção. Há também situações em que até mesmo pais e acompanhantes sentiram-se sensibilizados para a importância e necessidade da educação formal manifestando a percepção e o desejo de retomar seus estudos.

\section{CONSIDERAÇÕES FINAIS}

Ao término deste levantamento de dados e análise dos mesmos foi possível concluir que a atuação do SAREH foi importante para os resultados obtidos pelos alunos. Os atendimentos pedagógicos durante a internação contribuíram para a apropriação de conteúdos e atuaram também como incentivo para sua volta à escola ao propiciar-lhes as condições para retomarem seus estudos sem prejuízo, como comprovou 
o índice de aprovação obtida por eles.

Como sugestão para trabalhos futuros indica-se aumentar a abrangência do estudo incluindo os indivíduos que estão fora do sistema educacional e que não foram atendidos pelo SAREH, as causas das desistências e formas de reinserção desses indivíduos à vida acadêmica. Outra sugestão é aplicar um estudo qualitativo com a mesma base de dados, alterando a metodologia, como por exemplo a utilização de entrevistas com os alunos, familiares e escola.

A presença do SAREH nos hospitais tem-se mostrado a cada ano uma intervenção de suma importância na qualidade de vida dos alunos internados, muitas vezes auxiliando sua melhora não apenas na questão educacional como também em suas enfermidades. Determina- se então a necessidade de ampliação dessa rede nos hospitais, além de promover melhoras no atendimento dos alunos após sua saída da instituição de saúde quando o mesmo fica afastado da escola se recuperando em sua residência. Comprovou-se a eficácia do programa demonstrando assim que o mesmo merece receber mais atenção da parte dos tomadores de decisão e ser ampliado. Por fim conclui-se que essa é uma área de trabalho promissora e de grande interesse.

\section{REFERÊNCIAS}

[1] Brasil. Resolução do Conselho Nacional de Educação, Câmara de Educação Básica (CNE/CEB) no 2 de 11 de setembro de 2001. Disponível em:<http://portal.mec.gov.br/seesp/arquivos/pdf/res2_b.pdf>. Acesso em: 20 de jul. de 2015.

[2] Ceccim, Ricardo B. Classes Educacionais Hospitalares e a Escuta Pedagógica no Ambiente Hospitalar. In: Paraná. Secretária de Estado da Educação. Serviço de Atendimento à Rede de Escolarização Hospitalar (SAREH). Curitiba: Seed-PR, 2010.p.33-37.

[3] Paraná. Portal dia-a-dia Educação. Programas e Projetos - Sareh - Legislação. Curitiba, 2015. Disponível em:<http://www.gestaoescolar.diaadia.pr.gov.br/modules/conteudo/conteudo.php?conteudo=464 . Acesso em: 21 de jul. de 2015.

[4] Taam, R. Pelas trilhas da emoção: A educação no espaço da saúde. Maringá: Eduem, 2004.

[5] Universidade de São Paulo. Biblioteca Virtual de Direitos Humanos. Constituição da Organização Mundial da Saúde - 1946. São Paulo, 2015. Disponível em:<http://www.direitoshumanos.usp.br/index.php/OMSOrganiza\%C3\%A7\%C3\%A3o- Mundial-da-Sa\%C3\%BAde/constituicao-da-organizacao-mundial-da-saudeomswho.html> Acesso em: 21 de jul. de 2015.

[6] Universidade Estadual De Londrina. Hospital Universitário. Missão. Londrina, 2015. Disponível em: <http://www.uel.br/hu/portal/> Acesso em: 20 de jul. de 2015. 


\section{Capítulo 17}

\section{Exercício artístico: Revistas e Lamentos, Grupo de Teatro Luz/Apadevi/Guarapuava}

\section{Eglecy do Rocio Lippmann}

Resumo: Este artigo busca discorrer sobre a proposta do grupo de teatro "Luz" da APADEVI, nestes 25 anos de existência, voltado para o resgate da efetiva inclusão que acontece através da arte. A pesquisa fundamenta-se na trajetória de execução de inúmeras peças, apresentadas por pessoas cegas e com baixa visão, com apresentações nos três estados da região sul do Brasil, em mais de 20 cidades atingindo uma platéia de aproximadamente 20 mil pessoas. Este trabalho surgiu da necessidade de registrar esta trajetória, uma vez que se apresenta como eficiente contribuição para a efetiva inclusão tanto pela proposta pouco convencional tanto quanto pelos resultados obtidos, uma proposta bastante consolidada no cenário cultural de nosso país, uma vez que em 2011 obteve no concurso de Arte Inclusiva, versão Albertina Brasil, do Ministério da Cultura (Minc) a maior nota como apresentação artístico cultural do sul do Brasil, obtendo a segunda maior pontuação no ranking nacional. Utilizou-se para tanto a pesquisa qualitativa com abordagem etnográfica. Assim sendo, podemos afirmar que é uma proposta que preenche a lacuna de práticas inclusivas consolidadas a partir da área de Arte, proposta pelo exercício sensível, como eficiente contribuição para realização da efetiva inclusão.

Palavras-Chave: Teatro, deficiência visual, inclusão 


\section{INTRODUÇÃO}

Ainda que se considere as discussões nas últimas décadas, da exigência de uma educação verdadeiramente para todos, percebe-se ainda a grande lacuna estabelecida entre o que se proclama e a realidade que se pratica em se tratando da realização da efetiva inclusão. Neste sentido, necessário se faz refletir sobre o exercício da nossa sensibilidade que não é um fim em si mesmo, mas um meio de conhecimento da própria realidade, em que se forjam as convenções ou atividades aceitas socialmente. Nosso desafio, enquanto pesquisadores e educadores, consiste na instrumentalização para que sejamos capazes de superar os condicionamentos impostos pelos estereótipos tanto reforçados na escola como por exemplo, ainda referendar de forma preconceituosa, os alunos como "normais ou deficientes".

Situamos aí a tarefa do educador, segundo NOGUEIRA (2008), em objetivar o desenvolvimento da percepção humana, entendendo que ela é construída histórica e culturalmente, condicionada à moldura de modelos impostos e passíveis de modificações. 0 que se propõe, portanto, a partir desta reflexão, é uma análise dos padrões culturais que comunguem com uma educação no sentido de trans-formação. Almejase a superação dos modelos a partir de uma educação estética.

Neste sentido a prática inclusiva a partir do teatro pelo grupo Luz, é proposto numa sensibilização estética e dos sentidos, no conhecimento artístico, estreitando relações de homem/mulher - corpo/mente e, ao mesmo tempo, homem/mulher-mundo, resgatando, a partir daí, o prazer, a alegria e a dinamicidade há tanto perdidas no cenário em que vivemos, possibilitando, assim, o rompimento com padrões culturais pré-estabelecidos; comungando, portanto, da educação estética no sentido de transformação e superação dos modelos a partir da arte estendendo-se a outros campos de conhecimento: Linguístico e literário, histórico, geográfico.

Nossa formação dentro do velho paradigma dominante há muitas centenas de anos, consolida no ser humano a insensibilidade, que o transforma num bloco olha sem ver, escuta sem ouvir, toca sem sentir, estuda sem saber, trabalha sem pensar, vive sem refletir. Necessário se faz restaurar esse ser fragmentado de volta à unidade. A cultura, enquanto conjunto de práticas que constituem o viver do ser humano em sociedade. Registrar e disseminar esta experiência no cenário acadêmico é possibilitar um repensar de práticas bem sucedidas que possibilitam o exercício de uma efetiva inclusão, mostrando o quanto é possível, finalmente, praticarmos aquilo que tanto proclamamos, e esta não é uma ação isolada, no entanto, são incipientes ainda, o registro de exercícios, metodologias e práticas pedagógicas no cenário científico com o resgate da dimensão estética do ser humano, como fator determinante para inclusão.2.metodologia

Compreendendo que o conhecimento se processa a partir de necessidades concretas de sobrevivência, de domínio sobre o real, ou desejos, sonhos, fantasias, igualmente importantes, porque as práticas deste presente trazem a perspectiva de futuro, optou-se assim pela pesquisa qualitativa - bogdan e biklen, numa abordagem etnográfica, pois valemo-nos dos registros documentais e vivenciais do grupo de teatro da apadevi (associação de pais e amigos dos deficientes visuais)/guarapuava, com início na década de 90, com o auto natalino o amor teima em nascer: pessoas cegas e com baixa visão, num palco, contracenando, e muito mais que um texto, trazendo possibilidades de quebrar esta barreira comunicacional humana, numa atividade cênica, tratando assim da compreensão de mundo que passa pela corporeidade, ou seja, pela vivência corporal, pela incorporação de significados, os apropriando do que lhes é impedido pela ausência de visão.

Na montagem das peças seguintes, o boi e o burro a caminho de belém (maria clara machado) e quem roubou meu futuro (sílvia ortoff) os aspectos pertinentes ao domínio do espaço, construção do pensamento e linguagem e somados às possibilidades de projeção social destes atores, atinge-se a predominância de sua eficiência e respectiva capacidade, no que se refere ao reconhecimento pelo outro de seus aspectos positivos, o que facilita a construção de uma auto-estima positiva.

"os gnomos de gnú" livre adaptação de umberto eco, atingiu o domínio dos padrões culturais que vigoravam, numa proposta de crítica social, repensando a lógica produtiva de nossa sociedade.

Na sequência foi montada com o grupo a peça "entre nós a nossa história", autoria dos próprios componentes, interação esta que trouxe tanto aos participantes propositores como ao público, um maior conhecimento e domínio de sua realidade existencial, interação com a realidade, refletindo sobre suas relações afetivas, familiares, sociais, culturais. 
A peça "ex turvo com/sensibilidade", inspirada no romance de chico buarque de holanda intitulado "estorvo". Neste momento, propõem-se trazer as questões de uma parcela da população que possuem deficiência visual, e diariamente são chamados a viver no mundo dos que enxergam, e isto se impõe como sobrevivência. No período de realização da peça, inverte-se o cenário e os ditos "videntes" tem seus olhos vendados e passam a protagonizar num mundo dos que não enxergam, e assim, pelos cegos são assistidos. Esta peça, que atingiu mérito pela sua pontuação no cenário nacional, foi convidada a ser apresentada na semana da primavera em setembro de 2013 no museu oscar niemayer em curitiba/pr. Além obviamente, de sua apresentação em cidades do rg do sul, santa catarina e paraná.

Finalmente com a peça "constructos sensíveis: fragmentos estéticos para inclusão" confundem-se o fazer artístico numa superação dos limites sensoriais da deficiência numa produção estética. "o exercício da curiosidade, convoca a imaginação, a intuição, as emoções, a capacidade de conjecturar, de comparar, na busca da perfilização do objeto ou do achado de sua razão de ser" (freire, 1996, p.98)

\section{RESULTADOS E DISCUSSÃO}

Neste contexto, é possível analisar as inúmeras visões imbricadas na questão da arte e da inclusão em nossa sociedade. Enquanto sujeitos de investigação tomou-se uma população específica da inclusão, quais sejam os/as portadores/as de cegueira, pelo fato de ser essa a área de atuação da pesquisadora e também por isso permitiu uma certa intimidade para tratar do assunto também como dos equívocos da visualidade de nossa cultura extremamente visual.

Tendo como direção que o exercício de formação da nossa sensibilidade não é um fim em si mesmo, mas um dos meios de superação da própria realidade, em que se forjaram as convenções ou atividades aceitas como estéticas, eis a questão que (im)põe - opõe! - as diferenças humanas. A questão da inclusão e seus equívocos são intencionalmente trabalhados do ponto de vista dos excluídos do sistema social, caminhando por um tênue fio entre o utópico e o real, e isto é possível e previsível no teatro, em sua manifestação enquanto espaço.

A arte, nesse contexto, mostrou-se como um aparato eficientíssimo para discutir a inclusão. Mas, antes de tudo e primordialmente, poderá mostrar ao mundo que existem outras dimensões de mundo: dos que não ouvem, dos que não vêem. Todavia um mundo em que todos sentem de maneiras diversificadas. Somente através reflexão a partir da sensibilidade é possível entender as diferenças entre um ser humano e outro, entre um ser humano e o mundo.

\section{CONSIDERAÇÕES FINAIS}

Percebe-se neste estudo que a atividade atinge seu propósito de resgar o inteiro, da construção da beleza em seu caráter universal, possibilitando com a desinibição, a autonomia, a liberdade de comportamento, a consciência de um existir no pertencimento, na consciência de que somos um só.

É possível afirmar nesta trajetória, que no longo destas produções artísticas, houve o resgate da auto estima e dignidade, trazendo com isto uma criatividade em bem viver, mostrando possibilidades de inclusão pela arte que trabalha a partir das capacidades e eficiências há tanto deixadas de serem desenvolvidas por nossa cultura da exclusão.

Há que se considerar também a dimensão social e transformadora que se propõe quando no centro, no palco, grupos minoritários passíveis de exclusão, apropriam-se desta tribuna para anunciar através da arte, suas capacidades e eficiências. Um existir na sua mais completa compreensão enquanto "Ser" humano.

\section{REFERÊNCIAS}

[1] Bogdan, R. e Biklen, S.K. Investigação Qualitativa em Educação. Porto: Porto Editora, 1994

[2] Buarque, C. Estorvo. 10 ed. São Paulo: Companhia das Letras, 1991

[3] Eco, U. Gnomos de Gnú. Barcelona: Editorial Lumen, 1994

[4] Freire, P. Pedagogia da autonomia: saberes necessários à prática educativa. Rio de Janeiro: Paz e Terra, 1996

[5] Machado, M.C. O Boi e o Burro a Caminho de Belém. Rio de Janeiro, enciclopédia Itaú Cultural, 1971 
[6] Nogueira, M.A. Teoria crítica, estética e educação. São Paulo: Cortez, 2008

[7] Orthof, S. Quem roubou o meu futuro? São Paulo: Editora Atual, 1996

[8] Vygotsky, L. A formação social da mente. Tradução José Cipolla Neto, Luis Silveira Menna Barreto, Solange Castro Afeche. São Paulo: Martins Fontes, 2005 


\section{Capítulo 18}

\section{O Proeja na educação do campo: Uma análise curricular da disciplina de Educação Física}

\section{Sâmmya Faria Adona Leite}

Resumo: 0 presente trabalho teve como objeto de pesquisa a análise da inclusão da disciplina de educação física na matriz curricular do Programa Nacional de Integração da Educação Profissional com a Educação Básica na Modalidade de Educação de Jovens e Adultos - PROEJA - em uma escola da zona rural de Boa Vista - Roraima. Os objetivos da pesquisa foram: conceituar as bases que fundamentam o currículo da educação física escolar na perspectiva da educação do campo e dos alunos do PROEJA; compreender de que maneira a disciplina de educação física pode se tornar significativa para o aluno do PROEJA dentro da realidade do campo; e relatar sobre a aplicabilidade da inclusão da disciplina de educação física no currículo do PROEJA da referida instituição. A questão norteadora baseou-se nas inquietações da autora ao considerar duas vertentes: o ensino médio - na modalidade de educação de jovens e adultos- alicerçado a formação profissional (curso técnico em agropecuária) e os propósitos de uma educação do campo; já que a instituição mencionada está localizada na zona rural do município de Boa Vista no Estado de Roraima. Quanto aos procedimentos metodológicos, utilizou-se a etnometodologia como método, por se considerar mais adequada para avaliar uma situação em determinado momento que ocorre em um grupo social; evidenciando quais as influências derivadas de experiências práticas e teóricas. Esse processo metodológico é de natureza qualitativa, constituído por uma pesquisa documental, bibliográfica e de campo, onde foram realizadas entrevistas com gestores da Instituição e a aplicação de questionários com os alunos do PROEJA. As considerações teóricas apresentam especificidades da compreensão dos alunos e gestores em relação à educação física, seus conteúdos e sua prática no âmbito escolar.

Palavras-chave: Educação do Campo. PROEJA. Educação Física. 


\section{INTRODUÇÃO}

O presente artigo derivou da inquietação ao ponderar a relação prática existente entre os propósitos da educação do campo e o ensino médio agregado à formação profissional (curso técnico em agropecuária), especificamente na modalidade de educação de jovens e adultos da Escola Agrotécnica da Universidade Federal de Roraima - EAGRO/UFRR, localizada na área rural da cidade de Boa Vista - Roraima.

Para tanto, analisou-se duas projeções históricas que delimitam o teor do enfoque: a educação do campo e a disciplina de educação física no âmbito escolar. Essas duas perspectivas são vinculadas ao Programa Nacional de Integração da Educação Profissional - PROEJA da Instituição em questão.

É fato que nem sempre a educação seguiu as diretrizes impostas nas legislações vigentes e ainda nos dias atuais percebemos falhas no processo do cumprimento efetivo. Por isso, cabe a preocupação: 0 currículo levado ao homem do campo é adequado ao que ele vivencia? A realidade do homem do campo é retratada no currículo? As diretrizes impostas pela legislação são efetivadas na prática?

Para o delineamento das respostas de tais indagações, foi construído um aporte teórico sobre 0 Currículo e suas Perspectivas apresentando uma abordagem sobre 0 Currículo da Educação do Campo, 0 Currículo da Educação Física, 0 currículo do PROEJA em normativas e O Currículo do PROEJA da referida instituição que conta com o posicionamento de autores como Boiago e Oliveira (2012), Souza Filho (2009), Ciavatta (2005) e outros.

0 método da análise do processo utilizado desta pesquisa foi a etnometodologia, condizente com o objeto de estudo, focando a relação do grupo social a ser pesquisado e os processos do meio. Para a legitimidade do aporte teórico, abordamos as diretrizes de Garfinkel (2006) onde o autor traça os caminhos da Etnometodologia.

Para explanar sobre esse aspecto em foco, um questionário foi aplicado com os alunos do PROEJA da EAGRO/UFRR e com os gestores educacionais diretamente envolvidos. Entendemos que por meio desse procedimento, tornou-se possível retratar a realidade dos sujeitos em questão e o posicionamento da Instituição diante de suas propostas curriculares.

Ao final da pesquisa chegou-se às considerações que a disciplina de educação física deve ser incluída na matriz curricular do Programa Nacional de Integração da Educação Profissional com a Educação Básica na Modalidade de Educação de Jovens e Adultos - PROEJA - da Escola Agrotécnica da Universidade Federal de Roraima - EAGRO/UFRR; enfatizando a necessidade de ampliação da abordagem deste debate na construção da prática de propostas educacionais condizentes com uma educação eficaz.

\section{METODOLOGIA}

Para nos orientar sobre a metodologia, autores como Gerhardt e Silveira (2009) e Fonseca (2002) sustentam os processos e métodos abarcados durante a pesquisa de campo. Já especificamente no tópico sobre o método, Garfinkel (2006) descreve a importância da etnometodologia neste tipo de análise.

0 tipo de pesquisa utilizado foi de natureza qualitativa, bibliográfica e documental, onde o enfoque etnográfico apresentou a etnometodologia como abordagem metodológica. 0 objeto de pesquisa foi: a inclusão da disciplina de educação física no currículo do PROEJA - sob a ótica da Educação do Campo.

Como método científico, foi aplicado a etnometodologia. Nas palavras de Garfinkel (2006), criador da pesquisa etnometodológica, tais estudos:

[...] tratam as atividades e circunstâncias práticas, e o raciocínio sociológico prático como se fossem temas de estudo empírico. Ao prestar a mesma atenção tanto às atividades banais da vida cotidiana, quanto aos acontecimentos extraordinários, vamos procurar apreendê-las como fenômenos de pleno direito. (GARFINKEL, 2006, p. 1)

Nessa linha, a etnometodologia analisa as crenças e os comportamentos do senso comum como componentes necessários para toda conduta socialmente organizada. 


\subsection{CURRÍCULO E SUAS PERSPECTIVAS}

O currículo é algo que está no cotidiano da escola, de forma expressiva e oculta. De forma expressiva, por meio da missão e valores da escola, e diretamente no PPP-Projeto Político Pedagógico; e de forma oculta, por meio dos agentes da educação, que às vezes, mesmo sem perceber, afetam o andando do processo escolar em sua forma de pensar e agir. Segundo Silva:

0 currículo oculto nas escolas serve para reforçar as regras que cercam a natureza e o uso dos conflitos. E estabelece uma rede de suposições que visa determinar regras sobre a conduta dos estudantes. (2003, p. 78)

Sabemos que além do professor que lida com o aluno diretamente em sala de aula, outros agentes da educação colaboram com o currículo. Diante disso, para esclarecimento, precisamos conceituar o que é currículo. Para Veiga Neto:

Currículo é uma construção social do conhecimento, pressupondo a sistematização dos meios para que esta construção se efetive; a transmissão dos conhecimentos historicamente produzidos e as formas de assimilá-los, portanto, produção, transmissão e assimilação são processos que compõem uma metodologia de construção coletiva do conhecimento escolar, ou seja, o currículo propriamente dito. (2002, p.7)

Logo, para que o currículo tenha alcance concreto, é preciso estar inserido dentro da realidade do aluno. Não basta apenas o conteúdo pedagógico propor isso, é preciso a efetivação na prática.

\subsection{CURRÍCULO DA EDUCAÇÃO DO CAMPO}

Mesmo as escolas do campo tendo seus arranjos de funcionamento próprios, a educação do campo ainda não se constitui em uma modalidade de ensino, como no caso da educação indígena. Mas grandes mudanças foram e estão sendo pleiteadas nos dias atuais, como as Diretrizes Operacionais para a Educação Básica das Escolas do Campo, do Parecer n ${ }^{\circ} 36 / 2001$ da relatora Edla de Araújo Lira Soares, e instituída pela Resolução CNE/CEB no 1, de 3 de abril de 2002.

A concepção de Educação do Campo proposta pelas Diretrizes Operacionais para Educação Básica nas Escolas do Campo (2001) vai além da concepção de educação rural que se tinha, a saber, uma educação que considerava apenas a dimensão econômica. A nova concepção abrange a emancipação humana, o atendimento as especificidades do campo, levando em consideração aspectos da cultura campesina, da identidade dos sujeitos em questão, das relações sócio-ambientais e também das organizações políticas. (BOIAGO e OLIVEIRA, 2012, p. 5)

Em 2008, a Resolução no 2 do CNE/CEB estabeleceu diretrizes complementares, normas e princípios para o desenvolvimento de políticas públicas de atendimento da Educação Básica do Campo. Em seu Art. 1o:

Art. 1ํ A Educação do Campo compreende a Educação Básica em suas etapas de Educação Infantil, Ensino Fundamental, Ensino Médio e Educação Profissional Técnica de nível médio integrada com o Ensino Médio e destina-se ao atendimento às populações rurais em suas mais variadas formas de produção da vida - agricultores familiares, extrativistas, pescadores artesanais, ribeirinhos, assentados e acampados da Reforma Agrária, quilombolas, caiçaras, indígenas e outros. (MEC, 2008) 
Essas Diretrizes, aprovadas pelo Conselho Nacional de Educação, refletem a preocupação na organização da educação do campo e as características específicas de cada região. Em 2013, com a publicação das Novas Diretrizes Curriculares da Educação Básica, também tratou das Diretrizes Operacionais para a Educação Básica nas escolas do campo:

(...) Ao lado disso, observa-se que algumas Cartas estaduais trazem referências mais específicas à educação rural, determinando, na oferta da educação básica para a população do campo, adaptações concretas inerentes às características e peculiaridades desta. É o que ocorre nos Estados de Alagoas, Bahia, Ceará, Maranhão, Sergipe e Tocantins, que prescrevem sejam os calendários escolares da zona rural adequados aos calendários agrícolas e às manifestações relevantes da cultura regional.

(...) Essa orientação também é identificada nos Estados do Pará, Paraíba, Roraima, Santa Catarina, Sergipe e Tocantins, que determinam a fixação de currículos para a zona rural consentâneos com as especificidades culturais da população escolar. (MEC, 2013, p. 274)

O mesmo documento, ao se tratar de Roraima revela:

A Constituição de Roraima, no art. 149, II, diz que os conteúdos mínimos para o ensino fundamental e médio serão fixados de maneira a assegurar, além da formação básica, currículos adaptados aos meios urbanos e rural, visando ao desenvolvimento da capacidade de análise e reflexão crítica sobre a realidade. (MEC, 2013, p. 275)

Logo, ao se pensar em um currículo para uma escola do campo, é preciso pensar na realidade dos sujeitos e a contribuição das disciplinas para a formação básica e profissional.

\subsection{CURRÍCULO DA DISCIPLINA DE EDUCAÇÃO FÍSICA}

Diante de tantos benefícios já concretizados pela educação física é indiscutível sua atuação no âmbito escolar. A Lei no. 9394, de 20 de dezembro de 1996, que estabelece a Lei de Diretrizes e Bases da Educação Nacional traz em seu texto a obrigatoriedade da educação física escolar como currículo obrigatório em todo o ensino básico. E determinada que ela seja facultativa para os alunos que:

I. que cumpra jornada de trabalho igual ou superior a seis horas;

II. maior de trinta anos de idade;

III. que estiver prestando serviço militar inicial ou que, em situação similar, estiver obrigado à prática da educação física;

IV. amparado pelo Decreto-Lei no 1.044, de 21 de outubro de 1969;

V. (VETADO);

VI. que tenha prole.

Em 2012 novas Diretrizes Curriculares Nacionais foram lançadas. Estas são fixadas pelo Conselho Nacional de Educação (CNE) com o proposito de orientar as políticas educacionais e implementar propostas curriculares em todo o Brasil. Em cooperação com as DCN's estão os PCN's - Parâmetros Curriculares Nacionais - que são referenciais de qualidade elaboradas pelo Governo Federal e oferecem embasamento teórico para nortear as escolas na execução do currículo.

Estes Parâmetros propagam os princípios da base curricular e orientam os profissionais ao propor abordagens e metodologias. Os PCN's abarcam desde a organização dos conteúdos de cada disciplina quanto à forma de abordagem, auxiliando os docentes da área numa perspectiva de conduta positiva para múltiplas situações.

É importante salientar que, nem as Referenciais Curriculares Nacionais da Educação Profissional e nem as Diretrizes Curriculares Nacionais para a Educação Profissional de Nível Técnico orientam sobre as disciplinas da educação básica, como a educação física, e sim sobre as disciplinas de cada curso da área técnica. 
Mas alguns autores revelam a importância da disciplina em nível técnico, é o caso de Souza Filho (2009 apud GUIMARÃES; VALDEZ). 0 autor esclarece sobre a educação física no PROEJA:

[...] para a Educação Física consolidar-se como componente curricular no PROEJA e colaborar para que o sujeito EJA se reconheça como ser pensante e atuante na sociedade, as aulas deveriam ser desenvolvidas a partir da perspectiva dos alunos, das suas representações, de suas ideias e dos seus interesses de modo que esses aspectos promovessem uma ação pedagógica afirmativa, tanto no processo de ensino orientado quanto no processo de aprendizagem participante (2009, p. 119-120).

O próprio autor ainda acrescenta em suas falas sobre a aplicabilidade da educação física para jovens e adultos, muito além de uma disciplina, um meio de inserção social.

[...] seria relevante para a Educação Física estar presente no processo de inclusão sócio-educacional e cultural dos alunos da EJA e, nesse processo, analisar, discutir e valorizar a história de vida desses sujeitos, as marcas tatuadas na sua corporeidade, os seus valores, as suas concepções políticoideológicas e econômicas, a sua dimensão cultural e a sua percepção de mundo (SOUZA FILHO, 2009, p. 120).

Outra fonte que orienta o caminho da educação física no PROEJA, é a Proposta Curricular de Educação Física para a EJA, que foi criada em 2002 pela Secretaria de Educação Fundamental com base na Resolução no 01/2000 (Estabelece as Diretrizes Curriculares Nacionais para a Educação e Jovens e Adultos) e no Parecer CNE/CEB no 11/2000 (Diretrizes Curriculares Nacionais para a Educação de Jovens e Adultos). A Proposta é composta por dois volumes, que se dividem em disciplinas e áreas e estabelece as competências, com o objetivo de:

[...] promover a integração e a inserção de todos os alunos nas práticas corporais; valorizar, apreciar e desfrutar dos benefícios advindos da cultura corporal de movimento; perceber e compreender o papel do esporte na sociedade contemporânea; usufruir do tempo livre de lazer, resgatando o prazer enquanto aspecto fundamental para a saúde e melhoria da qualidade de vida; valorizar, por meio do conhecimento sobre o corpo, a formação de hábitos de cuidado pessoal; compreender e ser capaz de analisar criticamente valores sociais como padrões de beleza, relações entre os sexos e preconceitos (BRASIL, 2002, p. 205-206).

Atualmente, almeja-se que as aulas de Educação Física possam oportunizar o aluno a vivenciar a diversidade das práticas corporais por meio de conhecimentos que enfatizam a cultura corporal de movimento, considerando a evolução individual de cada educando.

\subsection{CURRÍCULO DO PROEJA}

O currículo escolar constitui a organização de conteúdos diante das relações que acontecem entre os agentes da educação. Para integrar o currículo básico com a formação profissional, é preciso coerência nos processos de ensino-aprendizagem. Ao se falar no currículo que integra a formação básica com a formação para o trabalho, tem-se:

Como formação humana, o que se busca é garantir ao adolescente, ao jovem e ao adulto trabalhador o direito a uma formação completa para a leitura do mundo e para a atuação como cidadão pertencente a um país, integrado dignamente à sua sociedade política. Formação que, neste sentido, supõe a compreensão das relações sociais subjacentes a todos os fenômenos (CIAVATTA, 2005, p. 85). 
Os cursos do PROEJA podem ser oferecidos da seguinte forma, de acordo com a construção do projeto pedagógico integrado:

1- Educação profissional técnica integrada ao ensino médio na modalidade de educação de jovens e adultos.

2- Educação profissional técnica concomitante ao ensino médio na modalidade de educação de jovens e adultos.

3- $\quad$ Formação inicial e continuada ou qualificação profissional integrada ao ensino fundamental na modalidade de educação de jovens e adultos.

4- Formação inicial e continuada ou qualificação profissional concomitante ao ensino fundamental na modalidade de educação de jovens e adultos.

5- $\quad$ Formação inicial e continuada ou qualificação profissional integrada ao ensino médio na modalidade de educação de jovens e adultos.

6- $\quad$ Formação inicial e continuada ou qualificação profissional concomitante ao ensino médio na modalidade de educação de jovens e adultos. (BRASIL, Decreto 5.840/2006)

O Decreto no 5.840, de 13 de julho de 2006 que institui, no âmbito federal, o Programa Nacional de Integração da Educação Profissional com a Educação Básica na Modalidade de Educação de Jovens e Adultos - PROEJA, estabelece em seu Art. 3ํㅡㄹ e Art. 4ำ que:

Art. 3o Os cursos do PROEJA, destinados à formação inicial e continuada de trabalhadores, deverão contar com carga horária mínima de mil e quatrocentas horas, assegurando-se cumulativamente:

I - a destinação de, no mínimo, mil e duzentas horas para formação geral; e

II - a destinação de, no mínimo, duzentas horas para a formação profissional.

Art. 4ํㅡ Os cursos de educação profissional técnica de nível médio do PROEJA deverão contar com carga horária mínima de duas mil e quatrocentas horas, assegurando-se cumulativamente:

I - a destinação de, no mínimo, mil e duzentas horas para a formação geral;

II - a carga horária mínima estabelecida para a respectiva habilitação profissional técnica; e

III - a observância às diretrizes curriculares nacionais e demais atos normativos do Conselho Nacional de Educação para a educação profissional técnica de nível médio, para o ensino fundamental, para o ensino médio e para a educação de jovens e adultos. (BRASIL, 2006)

Segundo o mesmo decreto:

§ 3ํㅡㄴ 0 PROEJA poderá ser adotado pelas instituições públicas dos sistemas de ensino estaduais e municipais e pelas entidades privadas nacionais de serviço social, aprendizagem e formação profissional vinculadas ao sistema sindical. (BRASIL, Decreto 5840/2006, art. 1ํ)

Nas Diretrizes Curriculares Nacionais para a Educação Profissional Técnica de Nível Médio, criada pelo parecer CNE/CEB № 11/2012 consta que o Decreto 5.154/2004 integrou novamente o ensino médio à educação profissional técnica de nível médio, fazendo com que a CNE - Conselho Nacional de Educação reformulasse as Diretrizes Curriculares Nacionais para o Ensino Médio e as Diretrizes Curriculares Nacionais para a Educação Profissional Técnica de Nível Médio, por meio da Resolução CNE/CEB no 1/2005, com fundamento no Parecer CNE/CEB no 39/2004. No texto, as Diretrizes enfocam que:

Espera-se que o mundo do trabalho avance na direção de relações trabalhistas mais justas. Isso implica numa maior participação dos trabalhadores nos destinos e nos processos de trabalho. Para que isso aconteça é necessário que o trabalhador tenha conhecimento da tecnologia, da ciência e dos processos necessários em sua produção. A escola especializada ou voltada para a 
formação profissional deve atentar para essa necessidade.(BRASIL, 2013, p. 208)

Em 2008, a LDB teve uma Seção acrescida pela Lei no 11.741, a Seção IV-A, que demanda sobre a Educação Profissional Técnica de Nível Médio. Em seu paragrafo único é retratado que:

Parágrafo único. A educação profissional técnica de nível médio deverá observar:

I - os objetivos e definições contidos nas diretrizes curriculares nacionais estabelecidas pelo Conselho Nacional de Educação;

II - as normas complementares dos respectivos sistemas de ensino;

III - as exigências de cada instituição de ensino, nos termos de seu projeto pedagógico. (BRASIL, 1996)

Assim, impossível pensar em educação com distanciamento da formação profissional do sujeito, essa formação intrínseca com a cultura, a econômica, a política e as questões sociais, fazendo com que o aluno, seja um cidadão atuante na sociedade.

\subsection{PROEJA NA ESCOLA AGROTÉCNICA DA UFRR - EAGRO}

A Escola Agrotécnica da Universidade Federal de Roraima - EAGRO/UFRR - possibilita a formação na educação profissional técnica integrada ao ensino médio na modalidade de educação de jovens e adultos. 0 curso técnico proposto é de Agropecuária, e foram organizados com base nas Resoluções CEB/CNE 3/98, que institui as diretrizes curriculares nacionais para o ensino médio, e CEB/CNE 6/12, que define as diretrizes curriculares nacionais para a educação profissional técnica de nível médio.

Na modalidade PROEJA os alunos tem aulas durante os turnos matutino e vespertino, com o currículo de três (03) anos organizados em séries anuais e estágio obrigatório.

(...) 360 horas para o ensino médio integrado e 240 horas para na Modalidade PROEJA e o tempo máximo para integralização da matriz curricular, incluindo o estágio, será de 05(cinco) anos. Durante os três anos de duração são ofertadas todas as disciplinas necessárias para a base técnica e do ensino médio aos alunos. 0 curso busca promover a articulação entre os saberes que devem contemplar a formação geral desenvolvida pelo ensino médio articulado às necessidades e expectativas conceituais da formação profissional. $\mathrm{Na}$ Modalidade PROEJA, busca-se ainda, a valorização dos saberes adquiridos em espaços de educação não-formal. (Projeto Pedagógico do Curso Técnico em Agropecuária, atualizado em abril de 2013)

O Projeto Pedagógico da EAGRO/UFRR foi atualizado em abril de 2013 e dispõe sobre a matriz curricular do Curso Técnico em Agropecuária Integrado ao Ensino Médio na Modalidade de Educação de Jovens e Adultos (PROEJA) com uma parte comum, uma parte diversificada, uma parte da formação profissional e o núcleo completar referente ao estágio supervisionado. Esta matriz não adere a disciplina de educação física na grade curricular.

\section{RESULTADOS E DISCUSSÕES}

Foi realizado um questionário aplicado com os alunos do PROEJA da EAGRO/UFRR e também uma entrevista com os gestores da referida instituição para que informações gerenciais ficassem evidentes no processo de análise. Considerando as respostas do questionário o que mais se destaca no entendimento dos alunos perante a disciplina de educação física são conteúdos esportivos, que gerem gasto energético para proporcionar uma melhor qualidade de vida.

Contudo, é importante lembrar que a educação física não é somente para atletas ou para a descoberta deles. A sua dimensão na formação humana é bem maior. Claro, que o esporte tem papel de ênfase na disciplina, mas como uma fonte de diversão, lazer e bem-estar, possibilitando o trabalho de concentração, raciocínio e disciplina nas tarefas propostas. Como acentua De Marco (1995):

Mais do que formar atletas, a educação física pode contribuir com o desenvolvimento pleno da pessoa, com a formação de uma consciência crítica, 
com o conceito de cidadania e com o próprio desenvolvimento da consciência corporal (DE MARC0, 1995, p. 33)

O que se percebe é que eles não vivenciaram a prática esportiva na escola, já que se trata de um público em que não cursou o ensino regular. Em virtude da ausência dessas práticas, procuram interligar o esporte aos momentos de lazer, de jogos, ressaltando sempre a preocupação com a qualidade vida. Muitas vezes esses quesitos podem ser proporcionados não somente pelo esporte, mas por atividades lúdicas que trazem a realidade social de cada um, valorizando a cultura corporal de movimento e deixando de lado a esportivização.

Embora um dos gestores acredite ser desnecessário a inclusão da disciplina de educação física no PROEJA, sob a legação que já praticam atividade física nas ações das disciplinas técnicas, as questões corporais não se baseiam apenas no gasto energético. Suas dimensões são ampliadas quando nos referimos aos aspectos conceituais, atitudinais e procedimentais que a educação física propõe de acordo com cada atividade. Essa atividade evidenciada pelo movimento corporal de cada sujeito, o fazendo repensar sobre como mesmo se vê e sua imagem corporal diante dos outros. Darido S.C. et al (2001), dispõe sobre isso quando se refere nas dimensões sobre os conteúdos:

Neste sentido, o papel da Educação Física ultrapassa o ensinar esporte, ginástica, dança, jogos, atividades rítmicas, expressivas e conhecimento sobre o próprio corpo para todos, em seus fundamentos e técnicas (dimensão procedimental), mas inclui também os seus valores subjacentes, ou seja, quais atitudes os alunos devem ter nas e para as atividades corporais (dimensão atitudinal). E, finalmente, busca garantir o direito do aluno de saber porque ele está realizando este ou aquele movimento, isto é, quais conceitos estão ligados àqueles procedimentos (dimensão conceitual). (DARIDO S.C. et al, 2001, p.21)

Para que isso se efetive é preciso pensar sobre o público-alvo a quem a educação física se destina e que os conteúdos propostos se tornem significativos com o intuito da inserção desses alunos. No caso específico, são alunos que não puderam concluir o ensino médio regular e tiveram ao longo da trajetória escolar, interrupções no reconhecimento das mudanças corporais e cognições relativas a esse processo.

(...). Na história da EJA, encontraremos uma constante: partir dessas formas de existência populares, dos limites de opressão e exclusão em que são forçados a ter de fazer suas escolhas entre estudar ou sobreviver, articular o tempo rígido de escola com o tempo imprevisível da sobrevivência. Essa sensibilidade para essa concretude das formas de sobreviver e esses limites a suas escolhas merece ser aprendida pelo sistema escolar se pretende ser mais público. Avançando nessas direções, o diálogo entre EJA e sistema escolar poderá ser mutuamente fecundo. Um diálogo eminentemente político, guiado por opções políticas, por garantias de direitos de sujeitos concretos. Não por direitos abstratos de sujeitos abstratos (ARROYO, 2005, p. 49)

Para um dos gestores, a disciplina de educação física não deveria ser incluída já que os alunos possuem uma grade curricular diminuída, onde outras disciplinas também tiveram redução da carga horária. Mas para o outro gestor, a disciplina deve ser incluída apenas com a reformulação de conteúdos, nos quais entre eles sugere: corporeidade (recomendação energética, hidratação, alimentação saudável, obesidade, anorexia); ergonomia; doenças; ginástica laboral; relaxamento; expressão corporal (imagem corporal)

Assim, diante das interpretações dos resultados obtidos e no embasamento teórico legitimado, entende-se que não é possível desassociar a educação física na formação do aluno como sujeito, esse, necessitando se reconhecer dentro da realidade que o cerca por meio de sua compreensão corpórea.

Contudo, ao enfatizar a inclusão, não deixamos de lado a preocupação com os instrumentos necessários para a integração com o currículo, agregando o aluno na cultural corporal de movimento e no exercício da cidadania e no sua condução crítica de sujeito, papel este do próprio ambiente escolar. Esses instrumentos referem-se aos conteúdos propostos pela instituição escolar, a carga horária destinada a esse meio e a metodologia empregada para tal.

Uma escola que assume por missão consolidar a capacidade e a vontade dos indivíduos de serem atores e ensinar a cada um a reconhecer no outro a mesma liberdade que em si mesmo, o mesmo direito à individualização e à defesa de interesses sociais e valores culturais, é uma escola de democracia,... (TOURAINE 1999, p.339). 
Nessa perspectiva, propomos como caminho para a organização do ensino-aprendizagem a flexibilidade do currículo, a interdisciplinaridade, as ponderações dos alunos e a reflexão sobre o contexto social e profissional.

\section{CONSIDERAÇõES FINAIS}

Desde Platão é indiscutível que a escola é essencial na formação humana, não como um conjunto de salas e pessoas; mas como um lugar em que se aprende a ética e a moral pelos conteúdos escolares, pelas regras, pela burocracia, pelo currículo, pelos agentes educacionais, pela gestão, pela solidariedade, pelo afeto. Pois a escola é um lugar social, político, econômico e cultural.

Da infância a fase adulta a escola tem o compromisso com a formação humana e isso compreende muito mais que a mecanização de disciplinas em um rígido tempo para assimilação de saberes. Além de possibilitar a formação profissional, a escola deve instigar o sujeito a boas ações, de caráter, respeito ao próximo e legalidade de seus atos pela constituição, tornando-o um ser crítico e participativo na sociedade.

Ao refletir sobre a inclusão da disciplina de educação física na matriz curricular do Programa Nacional de Integração da Educação Profissional com a Educação Básica na Modalidade de Educação de Jovens e Adultos - PROEJA - da Escola Agrotécnica da Universidade Federal de Roraima -EAGRO, possibilita-se um olhar sobre os ensino-aprendizagem direcionado a formação do sujeito-aluno.

Nessa perspectiva pedagógica, há uma demanda de fatores intrínsecos e extrínsecos do processo educacional, como a relação de educação-trabalho, perfil dos alunos, opiniões de gestores, currículo do PROEJA, fundamentação legal sobre a educação do campo e a prática da educação física no ambiente escolar.

Nesse contexto, ao analisar o objeto em questão, outros fatores também foram evidenciados como o resgate da cidadania dos sujeitos em formação, o EJA como política educacional do governo, a profissionalização, e as desigualdades sociais resultantes da falta de políticas públicas para a área rural. Por isso é primordial que a escola discuta com seus agentes envolvidos sobre as problemáticas em evidência e retorne à sociedade soluções; e isso só será possível com diálogo, pesquisa e conhecimento.

Quando falamos em jovens e adultos que não cursaram o ensino regular, no caso em questão o ensino médio, abordamos aspectos peculiares de cada sujeito, em vivências histórias heterogêneas. Adicionamos aí, as condições educacionais nada satisfatórias para o público-alvo, o aluno do campo.

Nessa dimensão, a inclusão da educação física como disciplina obrigatória deve favorecer a relação educação-homem-trabalho, colocando-o como sujeito cultural, histórico, político e econômico que é, e precisa se reconhecer como membro social.

Por isso, a instituição escolar inserida dentro dos parâmetros da educação do campo, deve elaborar o currículo em consonância com os anseios dos alunos diante da realidade que os cerca. Percebe-se assim a relevância que uma disciplina aponta em direção aos conteúdos proposto em harmonia com a concepção integral do ser humano; fundamentando um currículo efetivo de inclusão social, formação básica e capacitação profissional; construindo instrumentos pedagógicos enriquecedores para a melhoria do processo de ensino-aprendizagem.

Diante disso, a disciplina de educação física deve ser inserida na matriz curricular do Programa Nacional de Integração da Educação Profissional com a Educação Básica na Modalidade de Educação de Jovens e Adultos - PROEJA - da Escola Agrotécnica da Universidade Federal de Roraima - EAGRO/UFRR; fomentando ainda o estudo e as colaborações nessa área para que se tornem fonte de aprimoramento e qualidade na educação para o homem do campo, por isso propomos a continuidade dessa relevante pesquisa como forma de aprofundamento do trabalho apresentado.

\section{REFERÊNCIAS}

[1] Arroyo, M. G. Educação de jovens - adultos: um campo de direitos e de responsabilidade pública. In: Soares, L. (Org.). Diálogos na educação de jovens e adultos. São Paulo: Autêntica, 2005.

[2] Brasil. Diretrizes Operacionais para a Educação Básica nas Escolas do Campo. Brasília, Mec/Secad, 2002.

[3] Brasil, Lei de Diretrizes e Bases. Lei no 9.394/96, de 20 de dezembro de 1996. 
[4] Brasil. Parecer 16/1999. Diretrizes Curriculares Nacionais para a Educação Profissional de Nível Técnico. Brasília, Mec/Ceb, 1999.

[5] Brasil. Parâmetros Curriculares Nacionais: Educação física Secretaria de Educação Fundamental. Brasília: Mec/Sef 1997.

[6] Brasil. Decreto no 5.478, de 24 de junho 2005 (Revogado). Institui, no âmbito das instituições federais de educação tecnológica, o Programa de Integração da Educação Profissional ao Ensino Médio na Modalidade de Educação de Jovens e Adultos - Proeja. Diário Oficial da União. Poder Executivo. Brasília, DF, 27 de junho de 2005.

[7] Brasil. Decreto no 5.840, de 13 de julho 2006. Institui, no âmbito federal, o Programa Nacional de Integração da Educação Profissional com a Educação Básica na Modalidade de Educação de Jovens e Adultos - PROEJA, e dá outras providências. Diário Oficial da União. Poder Executivo. Brasília, DF, 14 de julho de 2006.

[8] Brasil. Mec. Conselho Nacional de Educação. Diretrizes Operacionais para a Educação Básica nas Escolas do Campo. Brasília, dez. 2013.

[9] Brasil, Mec. Resolução № 2 do Cne/Ceb, de 28 de abril de 2008. Estabelece diretrizes complementares, normas e princípios para o desenvolvimento de políticas públicas de atendimento da Educação Básica do Campo.

[10] Boiago, D. L.; Oliveira, C. M. Bases legais para uma educação do e no campo e as experiências educativas de uma escola de agroecologia na região norte do Paraná. IX Anped SUL - Seminário de Pesquisa em Educação na Região Sul. Caxias do Sul. Universidade de Caxias do Sul, 2012.

[11] Ciavatta, M. A formação integrada: a escola e o trabalho como lugares de memória e de identidade. In: Frigotto, Gaudêncio; Ciavatta, Maria; RAMOS, Marise (Orgs.). Ensino médio integrado: concepção e contradições. São Paulo: Cortez, 2005.

[12] Darido, S.C. Os conteúdos da Educação Física escolar: influências, tendências dificuldades e possibilidades. Perspectivas da Educação Física escolar. UFF, v.2, n.1, p. 5- 25, 2001.

[13] De Marco, A. Educação Física ou Educação Motora? In: Pensando a Educação Motora. Campinas: Papirus, 1995. p. 27-35.

[14] Fonseca, J. J. S. Metodologia da pesquisa científica. Fortaleza: UEC, 2002.

[15] Garfinkel, H. Studios en Etnometodología. Barcelona: Anthropos, 2006.

[16] Gerhardt, T; Silveira, D. T. (Org.). Métodos de pesquisa. Porto Alegre: Ed. da Ufrgs, 2009. (Série Educação a Distância).

[17] Roraima. Ministério da Educação. Universidade Federal de Roraima - Ufrr. Conselho de Ensino, Pesquisa e Extensão -Cepe. Resolução 006/2008 - Regimento Interno da Escola Agrotécnica - Eagro/Ufrr. Boa Vista - RR, 2008.

[18] Silva, T. T. Documentos de Identidade: uma introdução às teorias do currículo. Porto Alegre: Artmed, 2003.

[19] Souza Filho, M. S. A Educação Física e o processo de inclusão dos alunos do Proeja no Ifrn - Uma experiência pedagógica no campus Zona Norte de Natal RN, 2009 In Guimarães, Cristina; Valdez, Guiomar (Org.). Dialogando Proeja: algumas contribuições. Campos dos Goytacazes (RJ): Essentia Editora, 2009.

[20] Touraine, A. Poderemos viver juntos? Iguais e Diferentes. Petrópolis: Vozes, 1999.

[21] Veiga Neto, A. De Geometrias, Currículo e Diferenças IN: Educação e Sociedade, Dossiê Diferenças-2002. 


\section{Capítulo 19}

Representações de si sobre o processo de alfabetização em alunos da Educação de Jovens e Adultos

\section{Kelly Jessie Queiroz Penafiel}

Valéria Leite da Silva

Resumo: 0 presente trabalho teve por objetivo compreender as Representações de si no processo de alfabetização dos alunos da Educação de Jovens e Adultos (EJA). A pesquisa foi realizada em uma escola pública da região periférica do município de Vilhena, Rondônia. 0 estudo contou com a participação de 12 alunos com idades entre os 22 e os 69 anos e teve como metodologia uma abordagem qualitativa, estruturada em entrevista semidirigida, diário de campo e pesquisas bibliográficas. Compreende-se que a apresentação deste trabalho tem por desafio discutir de forma sucinta as representações que determinados indivíduos têm de si e que refletem as exigências que a sociedade letrada e capitalista lhes impõe diariamente, seja no preparo para as funções do mercado de trabalho, seja também para a vida diária. Os resultados da pesquisa permite-nos considerar que $91,7 \%$ dos entrevistados se sentem mais felizes, valorizados e independentes após a apropriação da leitura e escrita. Observou-se, durante a entrevista, a referência a sentimentos positivos e a uma elevada expectativa em relação à conquista de novos objetivos e ao domínio da leitura e da escrita. Por fim, é possível afirmar que os entrevistados têm uma Representação de si positiva, após se perceberem pertencentes a uma sociedade letrada. Para que se possa compreender mais sobre as representações de si, necessita-se de um maior aprofundamento e mais pesquisas na área da Psicologia. Entender o que motiva ou desmotiva um ser humano é algo muito particular e individual e, portanto, apontamos a necessidade de outras pesquisas.

Palavras-chave: Educação de Jovens e Adultos. Psicologia da Educação. Alfabetização de Jovens e Adultos. 


\section{INTRODUÇÃO}

Considerando a produção e a pesquisa sobre Representações de Si e sobre o aluno da Educação de Jovens e Adultos (EJA), o presente trabalho tem por intuito responder aos seguintes questionamentos: quais as representações que o aluno da EJA tem de si após a apropriação da leitura e escrita? Como ele se percebe fazendo parte desta sociedade letrada?

A pesquisa realizada objetivou compreender as Representações de si sobre o processo de alfabetização em alunos da EJA, investigando também como tais representações se relacionam com habilidades de leitura e escrita. Prioriza-se, assim, a pesquisa com metodologia qualitativa e descritiva, utilizando-se de diário de campo, entrevistas semidirigidas e averiguação bibliográfica. Importa destacar que a presente pesquisa passou pela apreciação de um Comitê de Ética em Pesquisa (CEP), tendo sido aprovada sob o Certificado de Apreciação e Avaliação Ética (CAAE) n.o 33863.1149.0000.5300. Deseja-se, com este estudo, obter uma visão direcionada especificamente ao aluno da EJA que, por algum motivo, não frequentou ou desistiu da instituição escolar, construindo, assim, uma visão científica na área educacional destinada ao aluno adulto.

0 trabalho tem, pois, por desafio apresentar de forma sucinta as Representações que determinados indivíduos têm de si diante de uma sociedade letrada e capitalista e que refletem as exigências que a sociedade letrada e capitalista lhes impõe diariamente, seja no preparo para as funções do mercado de trabalho, seja também para a vida diária.

\section{AS EXIGÊNCIAS DE UMA SOCIEDADE LETRADA}

Nossa atual sociedade exige do indivíduo que, além de saber ler e escrever, ele tenha domínio de certas habilidades ligadas à leitura e à escrita, tais como compreender e interpretar diferentes tipos de texto. De fato, conforme afirma Ferraro (2002, p. 30):

[...] a alfabetização tornou-se tão importante na sociedade americana que ser incapaz de ler e escrever causa profundos sentimentos de isolamento, de ser diferente e inferior, o que com frequência conduz os analfabetos a juntarem-se a grupo em que essa deficiência é desconhecida e em que eles podem obter algum status.

Com as atuais mudanças no mundo, sendo a informática uma das principais, nossas vidas têm sido afetadas. Os aparelhos eletrônicos, tais como celulares com capacidade de processar informações e armazenar arquivos, aparelhos de televisão cada vez mais sofisticados com imagens 3D, notebooks com inúmeras funções, vêm se incorporando às nossas vidas, fazendo com que o ser humano passe a ter mais contato com o mundo digital. 0 sujeito tem que estar atualizado e o domínio da leitura e da escrita passa a ter importância distinta da que tinha décadas antes. A chamada "era digital", no mínimo, exige a leitura para que o sujeito possa também pertencer a essa sociedade informatizada.

Esses avanços tecnológicos significativos convivem, no Brasil, com o fato de que o país ainda não conseguiu erradicar o analfabetismo, embora o venha tentando desde o extinto Movimento Brasileiro de Alfabetização (MOBRAL). Após tantos anos de luta, ainda temos um nível elevado de analfabetos no país. Em matéria publicada no portal do Ministério da Educação (MEC) em 2013, é possível constatar que o analfabetismo de jovens e adultos no Brasil passou de 11,5\% em 2004 para 8,7\% em 2012, na Pesquisa Nacional por Amostra de Domicílio (PNAD). A redução, embora significativa, ilustra a condição de desigualdade a que muitos são submetidos.

Considerando os pressupostos freirianos, o processo de leitura e escrita pode ser visto de forma "integradora ou separatista". Muitas vezes, o indivíduo, ao ser alfabetizado, passa a se integrar à sociedade capitalista; do outro lado da moeda, percebemos que essa sociedade que oferece inclusão também é separatista - o sujeito pode ser excluído por não saber ler e escrever. Assim, para Freire (2000, p. 24) "[...] do ponto de vista crítico, não é possível pensar sequer em educação sem que se pense na questão de poder.".

Em nossa sociedade ocidental, capitalista e neoliberal, o indivíduo acaba sendo discriminado por não saber ler, sendo a ausência do domínio da leitura e da escrita um indicativo de que ele não tem um poder aquisitivo que lhe garanta ter acesso a essa sociedade capitalista, levando o sujeito a sentir-se rejeitado e menos autônomo. Conforme afirma Gadotti (2013, sem paginação), "[...] quando falamos de educação já não discutimos se ela é ou não necessária. Parece óbvio, para todos, que ela é necessária para a conquista da liberdade de cada um e o seu exercício da cidadania, para o trabalho, para tornar as pessoas mais autônomas e mais felizes.". 
De acordo com pesquisa divulgada pelo Instituto Nacional de estudos e Pesquisas Educacionais Anísio Teixeira (INEP), em 2013, houve um crescimento no Índice de Desenvolvimento da Educação Básica (IDEB) nos anos iniciais de $0,3 \%$ do primeiro ao quinto ano. Entendemos que o país que investe na educação automaticamente está colaborando com a economia, mas compreendemos que este mesmo país pode ter um índice elevadíssimo de desigualdade social, favorecendo a elite e desfavorecendo a grande massa. Aranha (2006, p.343) afirma que, “[...] na sociedade dividida em classes, a posse do saber não se dá de maneira homogênea, mas excludente, privilegiando alguns poucos".

É nesta desproporção que se encontra o aluno da EJA. Ao analisarmos o processo de constituição dessa modalidade de ensino, deparamo-nos com os seguintes questionamentos: quem é o sujeito que frequenta a EJA?, Como ele se vê diante de uma sociedade que o exclui por não ter domínio do saber escolarizado?, Qual a representação que ele tem de si mesmo?. A reflexão sobre essas questões estimulou-nos a delinear a presente pesquisa, que tenta compreender como se representa este aluno.

\section{AS REPRESENTAÇÕES DE SI, AUTOESTIMA E A EJA}

La Taille e Harkot-de-La Taille (2004, p. 72, grifo dos autores) assim compreendem as Representações de $\mathrm{Si}:$

[...] "si mesmo" será entendido no nível das representações que as pessoas têm de si. Não se trata, portanto, de um diagnóstico objetivo das características que definem a personalidade de alguém, mas sim, de como este alguém concebe a si próprio. Para empregarmos um conceito cuja formulação verbal é mais explicita, "si mesmo" é um conjunto de representações de si.

O conceito de "Representação de $\mathrm{Si}$ ", portanto, está relacionado a uma autoavaliação, na qual o julgamento de si mesmo é inevitável. La Taille (2002) afirma que as Representações de si apresentam juízo de valor, sendo que podem ou não representar realmente o que a pessoa é ou podem refletir como o sujeito se imagina vista pelo outro. Logo, Miras (2004, p. 210) afirma que:

[...] o autoconceito postula a ideia do eu como objeto de conhecimento em si mesmo e atualmente tende a ser concebido como uma noção pluridimencional, que engloba representações sobre diferentes aspectos da pessoa (aparência e habilidades físicas, capacidades e características psicológicas diversas, capacidades de relação interpessoal e social, características morais [...]).

A sociedade, por sua vez, exige do sujeito qualificações para as quais muitas vezes não oferta tais possibilidades. Consequentemente, o indivíduo se constrói da forma que a ele convir. Por outro lado, questiona-se se a sociedade intervém na construção das Representações de si. La Taille e Harkot-de-La Taille (2004, p.77) afirmam que "[...] é na interação com o meio que o sujeito constrói suas representações, sem afirmar que simplesmente interioriza valores culturais, mas que os assimila de forma singular".

Às Representações de si estão, portanto, implícitos valores que refletem costumes, ética, moral e virtudes. No conjunto das Representações de si, o indivíduo sempre se perceberá como pessoa possuidora de valores positivos, mesmo que para o outro seja um indivíduo que fuja das convenções tradicionais.

A partir do momento em que estamos nos conhecendo, passamos a ser objeto de nós mesmos. Surge, então, a indagação de como o outro nos percebe e/ou nos julga, e se realmente somos o que queremos ser, ou se nos tornamos alguém que o outro quer que sejamos. Para La Taille (2004, p. 65-66, grifos do autor):

[...] se as representações de si são sempre valorativas, o ser objeto para o outrem deve também ser pensado no domínio dos valores. Se pensamos em nós mesmo como valor, a fortiori também pensamos os outros como valor e sabemos que somos assim pensados por eles. Portanto, a consciência fatual de si (a existência em si) é relacionada ao ser percebido pelos outros; e a consciência de si como valor (o EU) é relacionada ao ser julgado pelos outros. Todo problema reside em saber como se articulam o julgar a si próprio e o ser julgado por outrem.

La Taille (2004) destaca que os comportamentos dos indivíduos são complexos e que os seres humanos tendem a apresentar ao outro apenas o seu lado positivo - as qualidades e as virtudes, ou seja, apenas as condutas aceitáveis, mesmo que elas não correspondam verdadeiramente ao que a pessoa representa. Isso se dá uma vez que os seres humanos concedem muita relevância aos juízos de outrem, dando-lhe a oportunidade de julgamento. Nesse jogo de ser e parecer, a pessoa procura ser bem vista, ser alguém influenciável ou ser aceitável. Ainda segundo La Taille (2004, p. 72 grifos do autor), “[...] a busca de 
representações positivas é uma das motivações básicas das condutas humanas.”. O ser humano está constante modificação, buscando sempre o aperfeiçoamento, o conhecimento e o reconhecimento perante uma cultura ou sociedade. Passamos a ser juízes de nós mesmos, nos avaliando de forma positiva ou negativa e, assim, consequentemente assumindo Representações de si diversas.

\section{A AUTOESTIMA E A ALFABETIZAÇÃO DE JOVENS E ADULTOS}

No longo percurso estudantil de um indivíduo, percebe-se a importância da autoestima no processo de alfabetização. Em alunos da EJA, o sujeito, muitas, vem carregado de opressão e de deveres do dia a dia, ou seja, encontra grandes obstáculos para que consiga ser alfabetizado. Para Traversini $(2009$, p. 583) “o sentimento de opressão e de inferioridade, a vergonha, o estigma por não saber ler e escrever e o temor do preconceito são condições geradoras de baixa autoestima.".

Salientando, assim, a relevância da autoestima para o desenvolvimento do indivíduo compreende-se que quando ele consegue aprender a ler e escrever desenvolve o sentimento de superação e rompimento de barreiras. Travesini (2009, p. 584), nesse sentido, aponta que "[...] quando o analfabeto ingressa no curso de alfabetização e inicia a aprendizagem da leitura e da escrita, passa a 'se gostar, se respeitar e se valorizar' e, aos poucos, vai resgatando sua autoestima.".

Conforme afirma ainda Traversini (2009), desde os anos 1980, começou-se a relacionar autoestima com aprendizagem, assim focando a pedagogia construtivista. Nos adultos, as práticas de educação emancipatória desenvolvem a conscientização e a transformação de suas realidades, contribuindo para que não venham a se desestimular dos estudos, ocorrendo neles o sentimento de inferioridade e vergonha. De acordo La Taille (2004, p. 73) "a vergonha é o sentimento de queda original, não porque eu tenha cometido tal ou tal falta, mas simplesmente pelo fato de que 'caí' no mundo, e no meio das coisas e que preciso de mediação de outrem para ser o que sou.".

Atualmente, percebe-se que a autoestima do adulto encontra-se ligada a todos os desenvolvimentos, principalmente ao social, e para que o indivíduo alcance destaque exige-se dele a leitura e a escrita. Contudo, as dificuldades do dia a dia (desemprego, sustento familiar, jornada de trabalho, entre outros) são motivos que podem vir a desanimar os não alfabetizados a prosseguirem nos estudos.

Conforme afirmam Medeiros e Costa (2012), pode-se compreender que a autoestima é a leitura positiva de si mesmo, ou seja, se o sujeito conseguir se relacionar consigo mesmo de forma favorável passará, a viver melhor consigo e, consequentemente, com o outro e estará predisposto a compreender suas vitórias e derrotas. Terá, assim, uma representação positiva de si. Porém, os autores (2012, p. 126) expõem que "lamentavelmente nem sempre os adultos formam vínculos que favoreça a construção de um autoconceito sólido e isso poderá repercutir em problemas de relacionamentos, em reconhecer seu valor e suas potencialidades".

Seguindo essa concepção de que a autoestima contribui para a vida do ser humano, principalmente para o aluno que se encontra desmotivado em continuar, retomar ou iniciar os estudos, é que se faz necessário o incremento de pesquisas na área, proporcionando-nos um olhar e uma compreensão do outro.

\section{UMA PESQUISA SOBRE REPRESENTAÇÕES E EJA}

Conforme orientam Bogdan e Biklen (1994) a investigação qualitativa caracteriza-se por ter o ambiente natural como fonte dos dados e o pesquisador como seu principal instrumento.

Uma pesquisa que visa a investigar as Representações de si de alunos que frequentam a EJA deve se voltar para essa modalidade de ensino. No município de Vilhena/RO, ela é oferecida nas seguintes instituições: Um Centro Educacional, que, no ano de 2014, contava com uma turma de nove alunos, e um segundo Centro Educacional, com duas turmas - uma no período vespertino com 19 alunos e outra no período noturno com 22 alunos matriculados. Das escolas da rede municipal de ensino, duas atendem a demanda pela EJA: na primeira escola, é ofertado ensino de 1. ao 5. ano, sendo uma turma para cada ano, totalizando 40 alunos. Na segunda escola, nove alunos no 1. o ano, sete no 2.. , quatro no 3.o e onze no $4 . .^{\circ}$, sendo que nessa instituição o atendimento é multiseriado.

A escola onde se realizou a pesquisa encontra-se na região periférica do município e possui o diferencial de contar com duas salas atendendo a turmas do 1. ao 5.. ano do ensino fundamental de jovens e adultos,

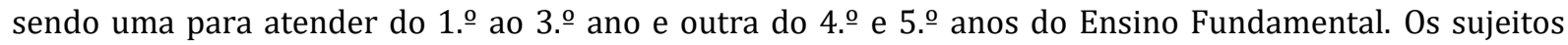
entrevistados foram alunos maiores de 18 anos que se encontravam em processo de alfabetização. As 
entrevistas ocorreram com sujeitos com a faixa etária de 22 a 69 anos, propiciando uma visão ampla e diferenciada da importância da leitura e escrita na vida dos participantes do estudo.

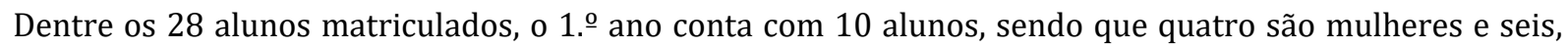
homens. Os alunos do 2. ano são duas mulheres e um homem; o 3.o ano contava somente com uma aluna. Já na turma do $4 .^{\circ}$ ano, eram cinco homens e três mulheres e, no 5.ํano, há quatro mulheres e dois homens.

Após um convite, 12 alunos se prontificaram a fazer parte da pesquisa. Foi-lhes, então, individualmente entregue o termo de consentimento livre e esclarecido, que foi lido pela pesquisadora. Após a leitura do documento, todos concordaram com o seu conteúdo e assinaram-no. Para garantir o sigilo e preservar a identidade dos participantes, os seus nomes foram substituídos por identificações que aqui serão apresentadas como Aluno 1 (A1), Aluno 2 (A2) e assim por diante até o Aluno 12 (A12).

No quadro 01, apresentamos os dados de caraterização dos participantes do estudo.

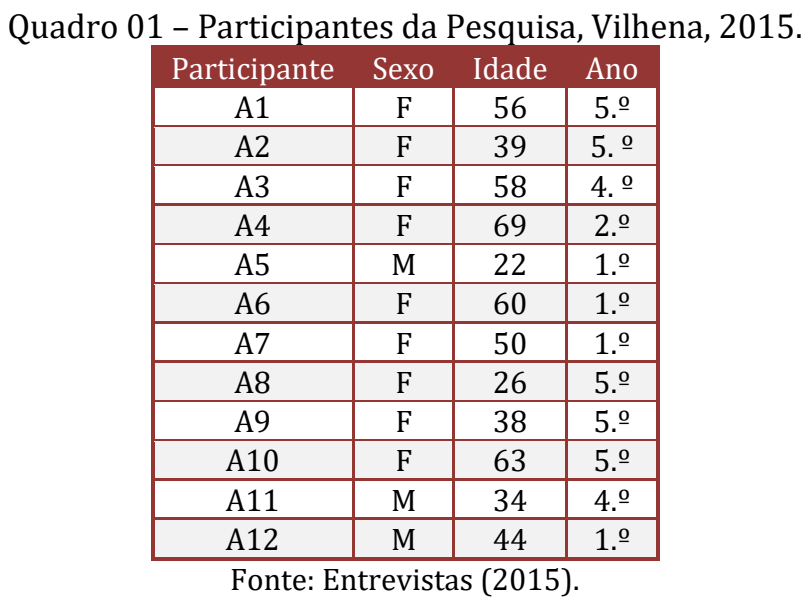

O quadro acima apresentou uma porcentagem significativa de mulheres frequentando a EJA - 75\% são mulheres e $25 \%$ são homens. Dos 12 entrevistados, quatro frequentam o primeiro ano, um, o 2.ำ ano, dois

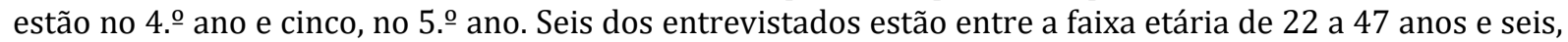
entre 48 a 69 anos. Os dados coletados por meio da entrevista permite-nos apontar que todos os participantes percebem a importância da leitura e da escrita em suas vidas, porém 45\% dos alunos não tiveram nenhum acesso à escola na idade considerada certo. Entre os 12 sujeitos, apenas cinco estudaram na infância/adolescência, três não estudaram, dois não informaram e apenas dois informaram que tiveram acesso à instituição escolar entre 15 dias a 04 meses atrás.

No quadro a seguir, são descritas, resumidamente, as respostas obtidas durante a entrevista no que diz respeito ao que estes indivíduos sentem, produzem, reproduzem sobre uma sociedade grafocêntrica que exige deles certas habilidades.

0 quadro 2 demonstra os objetivos e sentimentos dos indivíduos em relação à nova experiência da leitura e da escrita. Para expormos com riqueza de detalhes, apresentamos, em seguida, algumas questões feitas durante a entrevista, as quais têm trechos transcritos na íntegra da fala do entrevistado.

Dentre as questões feitas aos entrevistados, uma solicitava que nos informasse se havia apoio da família para se retornar aos estudos, ao que todos os doze entrevistados apontaram que pelo menos uma pessoa de sua família os apoiavam. Podemos citar como exemplo a resposta obtida com os entrevistados A8 e A10 - ambos responderam:

A minha mãe, meus familiares todinhos me ajudam bastante a permanecer e a não largar a escola. (A8, 26 anos).

Ah! Meus filhos, né?, sempre foram ao meu favor de estudar. (A10, 63 anos). 
Quadro 02 - Sentimentos e objetivos dos sujeitos, Vilhena, 2015.

\begin{tabular}{|c|l|l|}
\hline \multirow{2}{*}{ Participante } & $\begin{array}{c}\text { Sentimento após se apropriar da } \\
\text { leitura e escrita }\end{array}$ & \multicolumn{1}{c|}{$\begin{array}{c}\text { Objetivos/habilidades adquiridas após se } \\
\text { apropriar da leitura escrita }\end{array}$} \\
\hline A1 & $\begin{array}{l}\text { Independência } \\
\text { Maravilhada }\end{array}$ & $\begin{array}{l}\text { Escrever o nome no RG } \\
\text { Tirar CNH. }\end{array}$ \\
\hline A2 & Importante & $\begin{array}{l}\text { Ler a Bíblia } \\
\text { Cursar faculdade }\end{array}$ \\
\hline A3 & Vencedora, útil & Ler a Bíblia \\
\hline A4 & Independência & $\begin{array}{l}\text { Ler a Bíblia } \\
\text { Viajar sozinha }\end{array}$ \\
\hline A5 & Felicidade. & Deixar de ser dependente \\
\hline A6 & Felicidade & Aprender e trabalhar em órgão público \\
\hline A7 & Normal & Escrever o próprio nome \\
\hline A8 & Não informou & $\begin{array}{l}\text { Arrumar bom emprego } \\
\text { Ver as coisas de outro ângulo }\end{array}$ \\
\hline A9 & Está gostando & $\begin{array}{l}\text { Emprego melhor } \\
\text { Ler a Bíblia } \\
\text { Viajar }\end{array}$ \\
\hline A10 & Independência & $\begin{array}{l}\text { Pegar ônibus } \\
\text { Ler as placas } \\
\text { Usar celular e computador }\end{array}$ \\
\hline A11 & Independência & $\begin{array}{l}\text { Saber ler } \\
\text { Melhorar no trabalho }\end{array}$ \\
\hline A12 & Alívio e valorização & Renovar a CNH \\
\hline & & Fonte: Entrevistas (2015). \\
\hline
\end{tabular}

Como demonstram as respostas aqui reproduzidas, a família é a base e tende a colaborar e incentivar a pessoa a não desistir de seus objetivos. Compreende-se, assim, que as instituições da família e da escola devem ter e manter uma relação intrínseca de apoio e de auxílio.

Considerando a história de vida do aluno que frequenta a EJA, podemos imaginar diferentes situações que o fazem abdicar do ensino regular: necessidade de trabalhar para ajudar no sustento doméstico, dificuldades de acesso e permanência na escola, dentre outras. A próxima questão investiga o que levou esse sujeito, excluído do sistema escolar regular, a retornar para a escola. A7 responde:

Ah filha, que é ruim a gente ser assim não saber ler, né? Que eu sei só assinar meu nome só [...], só, esse aí onde eu chegar assino em qualquer lugar. Aí, eu pensei de voltar, não que eu vá arrumar emprego lá essas grande coisa, num vai, que a idade da gente vai chegando, vai ficando mais difícil, né? Mas a gente tem vontade... Naquela época, os pais da gente não dava essas coisas assim, o negócio deles era trabalhar, né?, trabalhar, trabalhar e trabalhar, num ligava com esse negócio de escola, mas se isso fosse no tempo de hoje já era diferente, né? Hoje em dia se um pai deixar um filho sem estudar, pelo amor de Deus, Deus o livre, aí não dá certo. (A7, 50 anos).

Através da fala da aluna A7 e de toda sua lembrança de um passado sofrido e não tão distante, podemos constatar e refletir sobre a dura realidade imposta a muitos brasileiros e brasileiras de diferentes regiões do país. 0 acesso à educação de qualidade ainda não é realidade na vida de todos.

Quando questionados sobre qual era a importância da leitura e escrita na sociedade, todos os 12 alunos informaram que as duas competências eram de suma importância. Temos que considerar que essa resposta possa ser fruto de um senso comum de que a escola é a única forma de as camadas populares alçarem outros níveis sociais. Procurando problematizar melhor essa questão, indagamos quais os motivos os levaram a iniciar os estudos na EJA. Todos responderam de formas diferentes, porém, suas respostas temem comum a ideia de que o estudo é necessário e responde às exigências de qualificação para o mercado de trabalho e para os usos sociais diários das habilidades de leitura e escrita.

É altura de refletimos sobre a leitura e a escrita na vida cotidiana sob uma diferente perspectiva: não apenas no domínio do saber escolarizado, mas acerca da capacidade de elas abrirem novos horizontes e possibilitarem as mais diversas experiências na vida de um ser humano. Para Silva e Arena (2014, p. 318): 
[...] pensar no ensino e na aprendizagem da leitura dos jovens e adultos, retirados durante a infância, é assumir um compromisso ainda maior, porque aprender a ler e escrever é um instrumento importante para se inserir no mundo e fazer parte dele porque a escrita e a leitura possibilitam a expressão do sujeito, a comunicação, a apropriação de diferentes conhecimentos que circulam na sociedade, que a movimentam e que a determinam. A escrita não é a única linguagem humana, mas, certamente, é a linguagem que permite acesso às mais diversas fontes do conhecimento.

A leitura e a escrita têm funções extraordinárias, podendo o sujeito, através delas, conhecer novas culturas, solucionar conflitos pessoais e sociais, expressar ideias e sentimentos, passando a desenvolver não só a leitura formal, mas também a "leitura de mundo", e a se perceber como sujeito que é valor e que tem valor diante de uma sociedade que gira em torno da leitura e da escrita sob múltiplos aspectos.

\section{0 QUE SENTEM OS ENTREVISTADOS?}

Falar de sentimentos não é tarefa fácil. 0 tema é carregado de subjetividade, o que o torna difícil de ser lido e interpretado pelo pesquisador. 0 que passamos a apresentar e a discutir em seguida é o resultado do que nos relatam os entrevistados sobre seus próprios sentimentos. A partir do que dizem, iremos trabalhar as questões.

Ao serem indagados sobre quais sentimentos eles apresentavam após terem se apropriado da leitura e escrita, quatro responderam que se sentem independentes e dois que se sentem felizes. Um expressou sentimento de valorização/alívio ao estar aprendendo cada vez mais, apenas um expressou o que chamou de "normalidade", um outro afirma "gostar" e dois se afirmam vencedores. Um entrevistado não informou. Percebemos aqui a importância da autoestima na vida de um aluno adulto, expressa na persistência, no sentimento de satisfação e na felicidade ao retomar os estudos após anos de vivência e experiência de mundo.

A EJA vem sendo cada vez mais valorizada, prestando atendimento a uma maioria de frequentadores que pessoas de baixo poder aquisitivo e que foram de certa forma privados de seus direitos básicos. Considerando essas questões, procuramos saber como os sujeitos se sentem após estarem aprendendo mais a leitura e escrita. $\mathrm{A} 12$ responde:

Tenho sentimento de alívio e valorização. A gente viver sem estudo é igual viver com uma venda nos olhos. (A12, 44 anos).

Conforme afirmam Soligo e Prado $(2005$, p. 37) "[...] não há nada que possa substituir nossa própria experiência de escrita - e leitura. Essa é uma experiência intransferível. Incomunicável. Pessoal. Única”. A leitura e a escrita começam a fazer parte do sujeito, que se percebe como se estivesse cego perante tanta beleza, destaque e valorização após a adaptação ao mundo letrado.

No contexto de nossa pesquisa, falar de sentimentos é falar também de Representações de si. Como vimos com La Taille (2004), a busca de representações positivas de si é uma das condutas básicas dos seres humanos. Procuramos, em seguida, compreender como se representam nossos entrevistados e quais habilidades foram desenvolvidas e/ou aprimoradas pelo aprender a ler e escrever.

\section{HABILIDADES DESENVOLVIDAS E/OU APRIMORADAS PELA LEITURA E ESCRITA}

A leitura vem passando a ser um exercício cada vez mais utilizado como forma de distração, fonte de informação e, principalmente, como terapia na vida de um sujeito. A cada dia, ela passa mais a assumir outros espaços além do escolar - passa também a ser coletiva durante as rodas de leitura e em panfletos informativos, por exemplo. Essencialmente intelectual e reflexiva, a leitura, contudo, não é ainda um hábito de todos, pois nem todos têm acesso a ela e/ou condições de adquirir matérias de escrita em abundância. De acordo com Lajolo (1993, p. 106):

Numa sociedade como a nossa, em que a divisão de bens, de rendas e de lucros é tão desigual, não se estranha que a desigualdade similar presida também à distribuição de bens culturais, já que a participação em boa parte destes últimos é mediada pela leitura, habilidade que não esta ao alcance de todos, nem mesmo de todos aqueles que foram à escola. 
Quando os alunos da EJA foram indagados sobre quais habilidades ou objetivos que queriam realizar após a aquisição da leitura e escrita, dentre os 12 sujeitos, quatro responderam que o objetivo era ler a Bíblia; quatro afirmaram estão desenvolvendo melhores habilidades no trabalho; dois afirmaram ter o objetivo de aprender; um, de futuramente conseguir cursar nível superior; três deram a mesma resposta: que gostariam de conseguir viajar sozinhos; um declarou ter a meta de fazer a Carteira Nacional de Habilitação (CNH); e um conseguir de renovar a CNH.

Atentemos, agora, para os pelos trechos a seguir:

Antigamente quando eu não sabia ler, eu ficava soletrando aquelas letrinhas. Às vezes, eu ia de ônibus lá pra baixo pro centro, eu sempre gostei de olhar nas placas, né?, que quando eu morava em São Paulo eu tinha que prestar atenção àqueles números pra não se perder, né? Eu tinha maior vontade e ficava soletrando, agora passa e eu leio tudo! (risos intensos). Agora eu falo pra minha neta: "olha, aquele vai pra tal lugar e tal vai pra tal lugar". (A3, 58 anos).

Tudo começou a melhorar, tenho que renovar minha habilitação, pois de antigamente a gente podia tirar a habilitação sem ter estudo, era só saber escrever o nome e vou ter que ir renovar. Então, vou precisar da habilidade da escrita e principalmente da leitura. (A12, 44 anos).

Conforme evidenciam os trechos citados, a leitura e a escrita passam a ser algo do cotidiano, tornando-o mais feliz, e incutindo no sujeito o sentimento de ser capaz, fazendo com que ele se perceba como uma pessoa independente, disposta a aprender coisas fora de seu cotidiano:

Hoje é tudo digital, mais fácil, né? Já tô aprendendo a mexer no celular, já vejo no Facebook (gargalhadas), estou aprendendo. (A10, 63 anos).

Para que se logre isso, a sociedade exige dos sujeitos qualificação - que se saiba não apenas ler e escrever, mas que se seja capaz de interpretar, informar, de estar preparado para essa sociedade digitalizada. A partir dessas bases, a pessoa terá que criar condições de automotivação para continuar aprendendo e ter novas ambições de vida. Percebemos, assim, que o indivíduo inicia um processo de participação na sociedade, que consegue desenvolver habilidades práticas e teóricas com mais reflexão, automaticamente se sentido mais preparado para qualquer situação que surgir, e construindo, como consequência, uma representação de si positiva.

\section{CONSIDERAÇÕES FINAIS}

É consensual que o aluno desmotivado vai se afastando da escola e acaba por desistir e passa a ser um forte candidato à EJA; esse aluno, por desistir da escola, poderá se sentir desvalorizado. Há, por outro lado, os alunos que não tiveram oportunidade de ter uma vida escolar, por motivos diversos, dentre eles, desconhecimento de seus pais da importância da leitura e escrita ou a necessidade de trabalhar para ajudar em casa. Assim, considera-se que o aluno que tem acesso à leitura e a escrita tem uma Representação de si positiva e automaticamente sua autoestima tende a ser alta, corroborando a perspectiva de que essas habilidades capacitam para resolver problemas, traçar mais objetivos e desenvolver habilidades que antes não se tinha ou que não eram aprimoradas.

Para que se possa compreender mais sobre as Representações de si, é necessário um maior aprofundamento e pesquisa na área da psicologia - entender o que motiva ou desmotiva um ser humano é algo muito particular e individual, assunto sobre o qual outras pesquisas são necessárias.

Visto que fatores internos e externos influenciam na vida do ser humano e na construção das Representações de si, compete à escola também a valorização do aluno, trabalhando de forma interpessoal, facilitando a convivência, a autoestima e a permanência deles na instituição, preparando-os para as mais diversificadas situações do cotidiano. Em se tratando de um estudante adulto, ele traz consigo toda uma carga emocional advinda da sua trajetória de vida. 


\section{REFERÊNCIAS}

[1] Aranha, Maria Lúcia de Arruda. História da educação e da pedagogia: geral e Brasil. 3. ed. São Paulo: Moderna, 2006.

[2] Bogdan, Robert; Biklen, Sari. Investigação qualitativa em educação: uma introdução à teoria e aos métodos. Porto: Porto Editora, 1994.

[3] Ferraro, Alceu Ravanello. A especificidade do fenômeno analfabetismo. In: ___ Analfabetismo e níveis de letramento no Brasil: 0 que dizem os censos? Campinas, vol. 23, n. 81, p. 21-47, dez. 2002. Disponível em: <www.scielo.br/pdf/es/v23n81/13930.pdf>. Acesso em: 23 set. 2014.

[4] Freire, Paulo. A importância do ato de ler. São Paulo: Cortez, 2000.

[5] Gadotti, Moacir. Educação de Adultos como Direito Humano. EJA em Debate, ano 2, n. 2, jul. 2013. Disponível em: <http://períodicos.ifs.edu.br/index.php/EJA>. Acesso em 25 set. 2014.

[6] Lajolo, Marisa. Do mundo da leitura para a leitura do mundo. São Paulo, SP: Ática, 1993.

[7] La Taille, Yves. Vergonha, a ferida moral. Petrópolis: RJ: Vozes, 2002.

[8] _ _ _ LA Taille, Elizabeth Harkot. A construção ética e moral de si mesmo. In: Souza, Maria Thereza Costa Coelho de. Os sentidos de construção: o si mesmo e o mundo. Casa do Psicólogo, 2004.

[9] Medeiros, Michelle Karinne Martins Roberto; Costa, Efigênia Maria Dias. A autoestima de alunos de Educação de Jovens e Adultos. Revista Movimenta, Vol.5 n1, p.119-133, 2012. Disponível em: <http://www.nee.ueg.br/seer/index.php/movimenta/article/viewFile/589/428>. Acesso em: 24 jan. 2015.

[10] Miras, Mariana. Afetos, emoções, atribuições e expectativas: o sentido da aprendizagem escolar. In: Coll, César; Marchesi, Álvaro; Palacios, Jesús (Orgs). Desenvolvimento psicológico e educação: psicologia da educação escolar 2. ed. Porto Alegre: Artmed, 2004.

[11] Silva, Greice Ferreira da; Arena, Dagoberto Buim. Ensino e Aprendizagem da leitura e escrita na educação de jovens e adultos: diálogos com a educação infantil. Educação, Santa Maria, v. 39, n. 2, p. 315-324, maio/ago. 2014.

[12] Soligo, Rosaura; Prado, Guilherme do Val Toledo. Leitura e escrita: dois capítulos desta história de ser educador. In: Prado, Guilherme do Val; Soligo, Rosaura (orgs.). Porque escrever é fazer história. Campinas, SP: Graf. FE, 2005.

[13] Traversini, Clarice Salete. Autoestima e alfabetização: o que há nessa relação? Cadernos de Pesquisa, v. 39, n. 137, p. 577-595, maio/ago. 2009. Disponível em: < http://www.scielo.br/pdf/cp/v39n137/v39n137a12.pdf>. Acesso em: 24 jan. 2015. 


\section{Capítulo 20}

O perfil do estudante de educação de jovens e adultos na rede municipal de ensino de Viçosa/MG

\section{Anmaly Natália Miguel Monteiro Gilbert \\ Eleusy Natália Miguel \\ Nádia Marota Minó}

Resumo: Este artigo buscou discutir resultados obtidos na pesquisa acerca da Educação de jovens e adultos- EJA, na cidade de Viçosa (MG). Para tal, optou-se pela pesquisa com abordagem descritiva, quantitativa no tocante aos dados relativos aos indivíduos concernentes do segmento educacional e bibliográfica para amparar os resultados encontrados na fase quantitativa. 0 principal objetivo deste estudo foi caracterizar o perfil dos alunos da EJA, vinculada a rede municipal de ensino. Os resultados apontaram para um quadro recorrente no Brasil, jovens entre 15 e 18 anos são os maiores frequentadores dessa escola, especialmente em função do formato educacional excludente em que são expostos. Ademais, este trabalho traz luz à urgência de políticas educacionais para esse segmento.

Palavras-chave: EJA, Viçosa (MG), Educação municipal. 


\section{INTRODUÇÃO}

Em princípio, é válido ressaltar que educação é um direito de todo cidadão brasileiro garantido pela Constituição Magna. Nesse sentido, entende-se a importância desse processo ser construído com qualidade e acesso para todos os segmentos que compõe o cenário da educação no Brasil.

A educação é composta por quatro segmentos: Educação Infantil, Ensino Fundamental I (anos iniciais), Ensino Fundamental II (anos finais) e Educação de Jovens e Adultos (EJA).

Para tal, optou-se pela pesquisa com abordagem descritiva, quantitativa no tocante aos dados relativos aos indivíduos concernentes do segmento educacional e a pesquisa bibliográfica para apoiar os resultados encontrados na fase quantitativa. Segundo Gil (2010), a pesquisa descritiva é baseada na explicação das características do objeto, o que vai ao encontro da proposta desta pesquisa. Para tal, foram utilizados os materiais dos bancos de dados, livros, teses e dissertações das universidades.

O principal objetivo deste estudo foi caracterizar o perfil dos alunos da EJA, vinculada a rede municipal de ensino. Dentro desse debate, problematiza-se que a população idosa portuguesa cresce a cada ano, e que a moradia tem importância relevante na vida do idoso. As questões relacionadas à casa têm repercussões em sua vida, interferindo diretamente no bem-estar, autonomia e independência. Nesse sentido, as políticas públicas podem ter relevante contribuição na solução de problemas e melhoria de vida das famílias, especialmente quando bem elaboradas e adequadas à realidade de seu público alvo.

Face ao exposto, busca-se com este artigo a discussão que engloba uma política pública: PCHI - Programa de Conforto da Habitação do Idoso em Portugal na perspectiva do envelhecimento ativo.

\section{A CIDADE DE VIÇOSA E SUA REDE MUNICIPAL DE ENSINO}

Ocorrida na primeira metade do século XIX, a colonização de Viçosa iniciou-se durante o declínio do ciclo do ouro em Mariana e Ouro Preto. Os pioneiros que se assentaram nessa região foram, em sua maioria, famílias vindas das zonas auríferas em busca de terras férteis para agricultura e pecuária, devido à crescente escassez de alimentos naquelas cidades.

A partir da criação da ESAV (Escola Superior de Agricultura e Veterinária), em 1922 pelo então Presidente da República, Arthur Bernardes, até a atual UFV - Universidade Federal de Viçosa, com base em que AMORIM (2006) descreve:

A cidade passou a se desenvolver significativamente, onde a ocupação e intervenções nas edificações aconteceram na medida em que fossem necessárias, sem ordenamento de crescimento (AMORIM, 2006, p 51).

Nos últimos anos, o crescimento da cidade foi alavancado pela pressão imobiliária, pressão essa caracterizada pela grande demanda principalmente oriunda da expansão da UFV, pelo aumento das escolas técnicas e pelo surgimento das faculdades particulares.

0 município de Viçosa, com área de $279 \mathrm{~km}^{2}$, está situado na região da Zona da Mata Mineira e limita-se com os municípios de Teixeiras, Guaraciaba, Paula Cândido, Coimbra, Porto Firme, São Miguel do Anta e Cajuri. Estas cidades formam a chamada microrregião de Viçosa por dependerem em alguma instância da cidade, seja em forma de parcerias entre as prefeituras e o consórcio de saúde, seja por parte dos moradores, que utilizam o comércio e os serviços, e de profissionais liberais e de ensino.

Atualmente, a população de Viçosa possui cerca de 80 mil habitantes, cerca de $92 \%$ de sua totalidade predominantemente urbana. É uma cidade de caráter estudantil, onde o potencial produtivo compõe-se do ensino e de serviços. Considerando sua população flutuante, de acordo com o último censo do Instituto Brasileiro de Geografia e Estatística (IBGE), em 2010 a cidade possuía 72.220 habitantes, sendo que dos 7.976 idosos (11,2\% do total) 55,5\% eram homens e 44, 5\% mulheres. A população estimada em 2016 foi de 77.863 habitantes.

A Rede Municipal de Ensino da cidade de Viçosa-MG é composta por 17 escolas. São quase cinco mil crianças, jovens e adultos atendidos; e os estabelecimentos se encontram tanto no centro da cidade, como nas periferias e em zonas rurais.

A Educação de Jovens e Adultos está presente em 03 estabelecimentos de ensino do município de Viçosa. Em 2017, são 280 estudantes matriculados em 14 turmas, que compreendem os anos iniciais e os anos finais da Educação Básica, e são divididas em 04 períodos por semestre: o primeiro segmento do ensino 
fundamental (anos iniciais) e o segundo segmento do ensino fundamental (anos finais), ambos com 04 períodos cada.

\section{RESULTADOS E DISCUSSÃO}

A cidade de Viçosa oferece, na modalidade de ensino para jovens e adultos, escolas da rede municipal, estadual e particular. Segundo o IBGE (2010), havia 146 alunos matriculados na alfabetização, 683 no ensino fundamental e 697 no ensino médio. Esses números contemplavam o total dos estudantes da EJA, ou seja, alunos matriculados nas escolas públicas e privadas no ano de 2010.

Na rede municipal, a Escola Municipal Coronel Antônio da Silva Bernardes está localizada no centro da cidade e possui um público de 564 estudantes. Nessa escola, a EJA atende 123 alunos em 06 turmas. A Escola Municipal Ministro Edmundo Lins, também localizada no centro da cidade, com 471 estudantes, possui um público de 88 alunos distribuídos em 04 turmas da EJA. Já a Escola Municipal Padre Francisco José da Silva, localizada em um bairro periférico do município de viçosa, possui 707 estudantes, sendo 69 em 04 turmas da EJA.

A Educação de Jovens e Adultos é uma modalidade educativa destinada àqueles que, por alguma razão, não frequentaram a escola na idade própria. É um segmento que exige dos envolvidos profissionalmente um olhar diferenciado daquele comumente direcionado aos estudantes do ensino regular.

Nesse sentido, pode-se afirmar: é chegada a hora de se desconstruir a ideia de que a educação básica deva, obrigatoriamente, acontecer na infância e/ou adolescência. A educação é um exercício que deve ser desenvolvido ao longo de toda uma vida. Sem tempo ou datas preestabelecidas. (SILVA, et al, 2012, p. 53).

Sabe-se que, na maioria dos casos, o estudante da EJA, ao retornar aos espaços de educação formal, carrega consigo marcas de vivencias relacionadas com suas dificuldades. Sendo assim, as trajetórias humanas desses educandos se sobrepõem às escolares e, levando esse fator em consideração, se a primeira não for compreendida, a segunda também não será (SILVA, et al, 2012, 57).

No caso do município de Viçosa/MG, é possível perceber a maior adesão de adolescentes e jovens nas salas de aula da EJA, enquanto o número de adultos é menor e o número de idosos é extremamente escasso. Esses dados podem ser analisados na tabela seguinte.

\begin{tabular}{|c|c|c|c|c|c|}
\hline \multirow{3}{*}{ Idade } & \multicolumn{5}{|c|}{ Idade dos Alunos da EJA em 2016} \\
\hline & \multicolumn{2}{|c|}{$\begin{array}{l}\text { Escola Municipal Coronel Antônio da Silva } \\
\text { Bernardes }\end{array}$} & \multirow[t]{2}{*}{$\begin{array}{l}\text { Escola Municipal } \\
\text { Ministro Edmundo } \\
\text { Lins }\end{array}$} & \multicolumn{2}{|c|}{$\begin{array}{l}\text { Escola Municipal Padre José } \\
\text { Francisco da Silva }\end{array}$} \\
\hline & Masculino & Feminino & & Masculino & Feminino \\
\hline 15 anos & 22 & 09 & 19 & 07 & 08 \\
\hline 16 anos & 13 & 20 & 59 & 06 & 08 \\
\hline 19 anos & 06 & 03 & 13 & 0 & 01 \\
\hline 20 anos & 03 & 03 & 14 & 01 & 01 \\
\hline 21 anos & 02 & 10 & 04 & 01 & 01 \\
\hline 22 anos & 02 & 0 & 02 & 07 & 08 \\
\hline 23 anos & 02 & 0 & 0 & 0 & 0 \\
\hline 24 anos & 0 & 03 & 0 & 01 & 0 \\
\hline 29 anos & 01 & 0 & 01 & 0 & 0 \\
\hline 30 anos & 0 & 0 & 0 & 01 & 0 \\
\hline 31 anos & 0 & 0 & 01 & 0 & 01 \\
\hline 33 anos & 0 & 02 & 0 & 0 & 0 \\
\hline 35 anos & 0 & 01 & 01 & 0 & 01 \\
\hline 36 anos & 0 & 0 & 03 & 03 & 0 \\
\hline
\end{tabular}


(Continuação ...)

\begin{tabular}{|c|c|c|c|c|c|}
\hline \multirow[t]{2}{*}{ Idade } & \multicolumn{2}{|c|}{$\begin{array}{l}\text { Escola Municipal Coronel Antônio da } \\
\text { Silva Bernardes }\end{array}$} & \multirow[t]{2}{*}{$\begin{array}{l}\text { Escola Municipal Ministro } \\
\text { Edmundo Lins }\end{array}$} & \multicolumn{2}{|c|}{$\begin{array}{l}\text { Escola Municipal Padre José } \\
\text { Francisco da Silva }\end{array}$} \\
\hline & Masculino & Feminino & & Masculino & Feminino \\
\hline 37 anos & 0 & 0 & 0 & 0 & 02 \\
\hline 38 anos & 0 & 0 & 01 & 01 & 0 \\
\hline 39 anos & 0 & 0 & 02 & 04 & 02 \\
\hline 40 anos & 0 & 02 & 0 & 01 & 0 \\
\hline 41 anos & 02 & 02 & 0 & 0 & 0 \\
\hline 43 anos & 0 & 01 & 02 & 0 & 0 \\
\hline 44 anos & 0 & 2 & 01 & 0 & 0 \\
\hline 46 anos & 01 & 01 & 0 & 0 & 01 \\
\hline 49 anos & 0 & 02 & 01 & 0 & 0 \\
\hline 50 anos & 0 & 0 & 01 & 0 & 0 \\
\hline 51 anos & 0 & 0 & 0 & 01 & 0 \\
\hline 52 anos & 01 & 0 & 0 & 0 & 0 \\
\hline 55 anos & 0 & 01 & 0 & 02 & 01 \\
\hline 61 anos & 0 & 02 & 0 & 0 & 0 \\
\hline 77 anos & 01 & 0 & 0 & 0 & 0 \\
\hline \multirow{2}{*}{ Total } & 88 & 79 & 189 & 40 & 43 \\
\hline & \multicolumn{2}{|c|}{167} & 189 & \multicolumn{2}{|c|}{83} \\
\hline
\end{tabular}

Fonte: Elaboração Própria.

O perfil do educando da EJA vem se modificando com o passar dos anos, mas, de maneira geral, são excluídos social, cultural e economicamente. As pessoas que frequentam as salas de aula desse segmento são, em sua maioria, trabalhadores, pobres, negros, subempregados. Apesar desse perfil, a realidade do município de Viçosa, em 2016, contempla um cenário com mais jovens do que adultos.

Atualmente há uma tentativa de atender de forma harmônica todos os sujeitos que compõem a demanda de Educação de Jovens e Adultos. Além disso, há também um processo de ressignificação, que vem sendo construído com base no perfil do jovem e do adulto que demanda escolaridade, bem como suas necessidades de escolaridade (SILVA, et al, 2012, p. 57). Deve-se levar em consideração algumas especificidades de jovens e adultos, como a diversidade social, cultural, sexual, religiosa, étnica, geracional, entre outras.

Esses dados foram disponibilizados pelas escolas envolvidas e também foi apresentado o resultado final do ano letivo de 2016. Assim, é possível perceber a elevada a taxa de evasão/desistência, se aproximando às taxas de aprovação e reprovação. Segue a tabela com os dados supracitados.

\begin{tabular}{|c|c|c|c|c|}
\hline \multirow[b]{2}{*}{ Situação final dos alunos } & \multicolumn{3}{|c|}{ Resultados dos Alunos da EJA em 2016} & \multirow[b]{2}{*}{ TOTAL } \\
\hline & $\begin{array}{c}\text { Escola Municipal Coronel } \\
\text { Antônio da Silva } \\
\text { Bernardes }\end{array}$ & $\begin{array}{l}\text { Escola Municipal } \\
\text { Ministro Edmundo } \\
\text { Lins }\end{array}$ & $\begin{array}{c}\text { Escola Municipal } \\
\text { Padre José Francisco } \\
\text { da Silva }\end{array}$ & \\
\hline Aprovação & 64 & 74 & 39 & 177 \\
\hline Reprovação & 44 & 49 & 11 & 104 \\
\hline Evasão/Desistência & 52 & 66 & 30 & 148 \\
\hline Transferência & 03 & 0 & 1 & 4 \\
\hline Outros & 04 & 0 & 02 & 06 \\
\hline Total & 163 & 189 & 81 & 433 \\
\hline
\end{tabular}

Fonte: Elaboração Própria.

Portanto, o desafio que vem sendo vivenciado na EJA do município de viçosa é a evasão dos alunos dessa modalidade. Esse fenômeno muitas vezes é decorrente da infantilização, o que pode ser percebido na linguagem utilizada, bem como nas propostas pedagógicas. Além da infantilização, a didática para trabalhar, tanto com jovens, como com adultos e idosos na mesma sala de aula, muitas vezes é um desafio 
para o docente ali presente e as propostas pedagógicas não tem suprido a diversidade que os sujeitos trazem para o ambiente.

A formação não específica dos educadores, a falta de uma metodologia especializada e a heterogeneidade das turmas culmina em problemas recorrentes na EJA. Além disso, refletem diretamente nos educandos, gerando um desestimulo e insegurança, como Ressalta Pocaro (2011):

- A falta de uma formação específica para o educador, no que se refere às diversidades dessa modalidade e em relação ao tratamento especifico dos conteúdos trabalhados.

- A heterogeneidade de níveis de aprendizagem dentro de cada turma, na qual o educador da EJA tem de atender, ao mesmo tempo, educandos que se encontram no início do processo de alfabetização e educandos que se encontram no final do processo.

- A grande diversidade entre os educandos, no que se refere às suas expectativas em relação aos estudos e as diferenças geracionais, religiosas, valorativas e de suas crenças.

- A grande diferença de idade entre os educandos jovens e adultos, o que gera conflitos de interesses e de posturas entre eles e, ate mesmo, uma impaciência recíproca, ocasionando a desmotivação para os estudos e, consequentemente, a evasão escolar.

- A baixa autoestima dos educandos, que não acreditam em sua capacidade de aprender, o que acaba por gerar bloqueios em seu processo de aprendizagem.

- A institucionalização do processo, gerando a rigidez própria do sistema regular.

- 0 processo de certificação dos educandos adultos, que gera a perda da qualidade no processo, devido a necessidade de sua padronização. (POCARO, 2011, p. 50)

Outro aspecto importante a ser observado com relação à EJA, é o idoso que participa. A velocidade do processo de envelhecimento no Brasil acarreta profundas mudanças no país em termos de demandas da população por saúde, habitação, previdência, lazer e educação. Esta se comporta como um dos componentes preponderantes para um envelhecimento ativo, sendo um dos quatro pilares sociais. Os outros três são saúde, participação social e proteção (BERNIZ e BORGES, 2012; ILP-BRASIL, 2015).

De acordo com o Instituto de pesquisa Aplicada (IPEA, 2010), a renda é o principal fator que define o analfabetismo no Brasil. Dados do IBGE confirmam que nas regiões, Sudeste, Centro-oeste, Norte e Nordeste, há uma relação direta entre alfabetização e renda.

Importante destacar o baixo nível educacional dos idosos. 0 analfabetismo no Brasil está concentrado na população mais velha, reduzindo apenas por meio do óbito, já que não há programas educacionais específicos para esta população (GOULART, 2010).

0 baixo número de idosos no programa, apenas 3 , no universo de 439 , é sem dúvida um indicativo que tanto o formato, quanto a metodologia utilizada na EJA não favorecem o ingresso e nem a permanência desse idoso no decorrer do período letivo. Para Rosa Porcaro (2011), o sistema educacional continua bastante exclusivo nos dias de hoje, não tendo tido modificações importantes no decorrer do tempo. Para o idoso, a juventização das classes, a dificuldades de acesso a escola, muitas vezes no período noturno, a baixa autoestima gerada pelos colegas e familiares e, por fim, a infantilização do idoso são fatores que agravam e justificam essa baixa demanda na EJA.

\section{4. À GUISA DE CONCLUSÃO}

Os resultados apontaram para um quadro recorrente no Brasil, jovens entre 15 e 18 anos são os maiores frequentadores dessa escola, por motivos variados, especialmente em função do formato educacional excludente em que são expostos. Ademais, este trabalho traz luz a urgência de novas metodologias, diretrizes e políticas educacionais para esse segmento.

Além disso, foi possível perceber que a taxa de evasão/desistência no segmento da EJA é extremamente elevada, quase se igualando às taxas de aprovação e/ou reprovação. Por se tratar de uma pesquisa de cunho qualitativo, não foi possível identificar as causas reais desse fenômeno, e por isso é oportuno 
ressaltar que o presente estudo não julga estar finalizado, desejando-se um aprofundamento que pretende abrir caminhos para o debate em torno das novas possibilidades que devem permear a Educação de Jovens e Adultos no município de Viçosa/MG.

\section{REFERÊNCIAS}

[1] Amorim, Ivana Costa. Patrimônio histórico-História, cultura e valores. Monografia de fim de curso do Departamento de Arquitetura e Urbanismo. UFV. Set 2006.

[2] Gil, A. C. Como elaborar projetos de pesquisa. Atlas São Paulo, 2010.

[3] Goulart, N. No Brasil, erradicar o analfabetismo é tarefa da natureza, não da educação. 2010 [acesso em 23 de março de 2014. Disponível em: <http://www veja. abril.com.br/noticia/educação/no-brasil-erradicar-o analfabetismo e tarefa da natureza-nao-da- educaçao $>$

[4] ILC-Brasil. Envelhecimento Ativo: um marco político em resposta à revolução da longevidade. Rio de Janeiro, 2015.

[5] Instituto Brasileiro de Geografia e Estatística, 2011 Acesso em 12 de junho de 2014. Disponível em: http://www.ibge.gov.br/home/estatistica/populacao/censo2010/sinopse/default_sinopse.shtm

[6] IPEA - Analfabetismo ainda é desigual entre regiões do Brasil. 2010, Acesso em 28 de março de 2014 .Disponível em: <http://ipea.gov.br/portal/index.php?option=comcontent\&view=article\&id=6542>.

[7] Poraro, R. C.. EccoS - Rev. Cient., São Paulo, n. 25, p. 39-57, jan./jun. 2011.

[8] Silva, Adelson Ferreira da; et al. As especificidades do sujeito da educação de jovens e adultos. In: Educação de jovens e adultos. Ilhéus, BA: Editus, 2012, 153p. (Pedagogia - módulo 6 - volume 3 - EAD). 


\section{Capítulo 21}

"Papagaio velho não aprende mais a falar": A educação humanística numa perspectiva libertadora

\section{Francinilda Rufino de Souza}

Jomar Ricardo da Silva

Resumo: 0 presente artigo tem como finalidade divulgar o desenvolvimento das atividades de alfabetização pautadas no método freireano, desenvolvidas pelo Programa de Extensão - Educação, Leitura e Arte: por um diálogo entre a cultura popular e a universidade - PROELART, financiado pelo PROEXT/SESu/MEC/UEPB). O Programa atualmente concluído, teve como objetivo contribuir para a diminuição dos índices de analfabetismo de jovens e adultos em comunidades da periferia de Campina Grande PB. As ações foram promovidas em torno da perspectiva de uma "pedagogia humanista e libertadora". Por isso o exercício inicial dos educadores foi visitar as comunidades atendidas pelo programa para conhecer suas realidades e fazer um levantamento das palavras geradoras a partir do universo e das identidades dos educandos para posteriormente fomentar neles, o domínio das habilidades de leitura e escrita a partir dos conteúdos advindos de suas leituras de mundo. Dessa forma, a alfabetização não se deu somente no campo cognitivo, acontecendo essencialmente nos campos social e político, tendo em vista que o alfabetizando é desafiado a refletir sobre seu papel na sociedade e levado a repensar a sua história. Portanto, de forma direita, constata-se impactos de ordem social, tendo em vista a contribuição que o programa proporcionou na melhoria de vida das populações atendidas, já que atuou na melhora da autoestima, e na formação crítica de sujeitos pensantes e capazes de reivindicar por seus direitos.

Palavras-chave: Alfabetização, Pedagogia Humanista e Libertadora, Educandos 


\section{INTRODUÇÃO}

A história da educação brasileira sempre esteve atrelada aos interesses das classes dominantes, que majoritariamente ditaram as regras no contexto de uma sociedade regulada pelos interesses do capital. Dessa forma, na relação entre políticas educacionais e sociedade, promoveu-se a exclusão de uma grande parcela da população, do espaço escolar e da cultura letrada. Essa trajetória fortaleceu o surgimento e a manutenção de uma oposição entre os sujeitos pensados como os que deveriam se voltar para o trabalho intelectual e aqueles ideais para o trabalho braçal. Esses brasileiros que, por sua vez, ficaram à margem do sistema escolar desaguam hoje nos programas de alfabetização do Estado.

o Brasil ainda possui uma triste realidade no que se refere as taxas de analfabetismo com cerca de 11,8 milhões de analfabetos, o que corresponde a $7,2 \%$ da população a partir da faixa etária dos 15 anos. 0 que indica que o Brasil não alcançou a meta 9 do Plano Nacional de Educação (PNE), que determinava a redução do analfabetismo a 6,5\% até 2015, sendo uma das metas intermediárias estabelecidas pelo PNE em relação à alfabetização da população com 15 anos ou mais. A Lei que regulamenta o Plano, diz ainda que em 2024 o analfabetismo deve estar erradicado do país ${ }^{36}$.

Na Paraíba taxa de analfabetismo mensurada no ano de 2017 representa o dobro daquela registrada no Brasil, além de estar acima da média estimada para d o Nordeste, que por sua vez, é a região do país com a maior taxa de pessoas que não sabem ler ou escrever. Enquanto na Paraíba foi de 16,5\%, a média de analfabetismo brasileira encontrada pelo IBGE foi de $7 \%$ e a média nordestina foi $14,5 \%{ }^{37}$.

Diante disso constatou-se a necessidade da criação e execução de um conjunto de ações que se contraponham a permanência destes índices a nível estadual, e a condição educativa que os produz ao mesmo tempo em que perpetua desigualdades sociais. E considerando fundamental que o mundo acadêmico desperte para o compromisso com a educação básica, reafirmando o aspecto extensão da tríade que norteia os objetivos da instituição de ensino superior e buscando promover o impacto social positivo. Tendo por base esse norte é que se construiu essa proposta que, no âmbito do campus I da Universidade Estadual da Paraíba (UEPB), buscou construir uma parceria com as comunidades localizadas nos bairros de: Bodocongó, onde trabalhamos especificamente na Vila dos Teimosos; São Januário II; Tambor; Novo Bodocongó; Ramadinha II; Mutirão; Monte Castelo e Bela Vista, em sua maioria situadas no entorno de Campina Grande-PB. Por meio do Programa de Extensão - Educação, Leitura e Arte: por um diálogo entre a cultura popular e a universidade - PROELART, financiado pelo PROEXT/SESu/MEC/UEPB).

O Programa que contou com uma equipe formada por dois Coordenadores (Jomar Ricardo da Silva e Maria José Guerra), dois professores educadores (Francinilda Rufino de Souza e Jociano Coêlho de Souza) e dezesseis alunos bolsistas que atuaram diretamente nas comunidades. Foram desenvolvidas atividades que contemplaram alfabetização, roda de leitura e teatro entre os meses de agosto de 2013 e agosto de 2014. Porém, neste artigo, serão contempladas apenas as ações de alfabetização.

Ao longo do desenvolvimento das atividades do Programa contamos com o apoio da Universidade Estadual da Paraíba, por meio da Pró-Reitoria de Extensão e Assuntos Comunitários e os departamentos de história, sociologia, comunicação social, pedagogia e letras. A equipe trabalhou com um público composto por homens e mulheres, trabalhadores formais e informais (comerciantes, soldadores de aço, domesticas, serviços gerais, manicures e etc.), cuja renda familiar é complementada pelo programa Bolsa Família.

Atualmente concluído no que concerne as ações de alfabetização, o Programa de Extensão teve como objetivo contribuir para a diminuição dos índices de analfabetismo de entre jovens e adultos nas comunidades carentes da periferia de Campina Grande - PB, favorecendo o exercício da cidadania. Este artigo, por sua vez, busca divulgar as ações desenvolvidas em torno desta proposta. As atividades tiveram como perspectiva metodológica a educação sob a perspectiva da "pedagogia humanista e libertadora" (FREIRE, 1981). Assim, pautadas no método freireano as ações estiveram intrinsecamente ligadas ao ideal de exercício de cidadania, haja vista que no processo de alfabetização concebido, os educadores estavam

36 O globo. Brasil ainda tem 11,8 milhões de analfabetos, segundo ibge. Disponível em: https://oglobo.globo.com/sociedade/educacao/brasil-ainda-tem-118-milhoes-de-analfabetos-segundo-ibge22211755. Acessado em: 20 de jul. De 2018.

37 g1 paraíba. População da paraíba tem 518 mil analfabetos, aponta estudo do ibge. Disponível em: https://g1.globo.com/pb/paraiba/noticia/populacao-da-paraiba-tem-518-mil-analfabetos-aponta-estudo-doibge.ghtml. Acessado em: 20 de jul. De 2018. 
claramente voltados a uma opção de construção de sociedade que se contraponha as diferentes formas de exclusão social ora vivenciadas.

O exercício inicial dos educadores foi o de visitar as comunidades atendidas pelo programa para conhecer suas realidades, para com isso fazer um levantamento das palavras geradoras a partir da realidade social dos educandos. Freire (1987, p.6):

Estas palavras são chamadas geradoras porque, através da combinação de seus elementos básicos, propiciam a formação de outras. Como palavras do universo vocabular do alfabetizando, são significações constituídas ou reconstituídas em comportamentos seus, que configuram situações existenciais ou, dentro delas, se configuram. Representativos das respectivas situações, que, da experiência vivida do alfabetizando, passam para o mundo dos objetos. 0 alfabetizando ganha distância para ver sua experiência: "admirar". Nesse instante, começa a descodificar.

Nesse momento a equipe percorreu a comunidade de casa em casa apresentando a proposta do Programa e convidando as pessoas a participar como alunos. Como ferramenta de coleta de dados para a elaboração de planos de ação específicos para cada grupo envolvido, os educadores elaboraram e aplicaram um questionário que foram preenchidos com dados daqueles que desejassem participar. Este instrumento contemplava dados pessoais para contato e perguntas como: "por que não estudou?"; "por que parou de estudar?"; "por que quer voltar a estudar?" e "em que trabalha?" Tal atividade teve como objetivo investigar o universo vocabular (FERREIRO, 2013) e os modos de vida específicos a cada comunidade. Essa investigação ia se aprofundando nas conversas informais estabelecidas entre a equipe de trabalho e os membros das comunidades, por meio das quais buscava-se perceber as suas vivências e experiências dos colaboradores/educandos nas esferas: familiar, religiosa, política, de lazer, de trabalho etc. esses contatos sempre forneciam a equipe de alfabetizadores um rol de palavras de uso comum em cada comunidade e que representavam o universo vocabular local (GUERRA, 2006).

Para operacionalização desta perspectiva, os educadores/bolsistas tinham em cada comunidade 4 (quatro) encontros semanais de segunda à quinta-feira nas comunidades atendidas pelo projeto de alfabetização de jovens e adultos. A duração do Programa PROELART foi de 12 (doze) meses, onde se pôde sistematizar os conhecimento prévios, advindos da pesquisa de campo e das experiências de mundo dos educandos, ponto de partida para a construção de saberes críticos a respeito do universo e do processo de intervenção. Desta forma, cada educador participou ativamente dos primeiros encontros/contato com as comunidades e com os educandos.

Esse exercício prático teve por objetivos:

- Instigar uma problemática para introduzir a palavra geradora que se aproximasse da realidade dos educandos;

- Introduzir a palavra geradora através da descoberta e não da imposição;

- Proporcionar a conceituação coletiva dos temas apresentados, sistematizando as palavras utilizadas pelos educandos em seu cotidiano;

- Trabalhar a leitura a partir deste conceito;

- Trabalhar a matemática ligada ao tema apresentado em sala de aula além de outras disciplinas do contexto escolar;

Na sequência das aulas, após a introdução da palavra geradora o(a) educador(a) procurou:

- Dinamizar a aula, incentivando no educando a oralidade para melhorar sua expressão e seu desenvolvimento intelectual através do diálogo;

- Trabalhar atividades que valorizassem a participação, a intervenção, a opinião, a crítica, entre outras qualidades suprimidas na sociedade oprimida e a margem.

Esse entendimento foi primordial para identificar o peso dos conteúdos programáticos que deveriam ser democraticamente escolhidos pelas partes interessadas no ato de alfabetizar, dentro de uma proposta mais ampla de educar. No intuito de fazer com que os sujeitos não sé fossem somente receptores passivos de conhecimentos, buscamos despertá-los para se verem enquanto indivíduos ativos e capazes de se apropriarem dos diferentes saberes. 
As atividades desenvolvidas em sala de aula promoviam uma sequência na qual fossem evidencializados os seguintes pontos:

1‥ A investigação da temática, ou seja, um estudo da realidade do universo vocabular dos educandos;

2o. A tematização, a escolha do tema geral ou temas geradores mediante o universo vocabular dos educandos;

3ํ. A problematização (as indagações, as discussões sobre a temática abordada).

4ํ․ A decodificação do código escrito, ou seja, a leitura da palavra e seus desdobramentos pelo método sintético (partindo da silaba, a palavra, a sentença e ao texto).

Dentro dos temas geradores ${ }^{38}$ e das palavras geradoras estudadas podemos destacar temas sociais como: Identidade, documentos pessoais, cidadania, direitos e deveres do cidadão, direitos humanos (saúde, educação, trabalho, moradia e segurança etc.) urbanismo, meio ambiente, temas sociais, e consumo, etc. A metodologia utilizava roda de conversa, diálogos, debates, conversas informais, dinâmicas, estudo de palavras, ditado de frases, produção de frases, trabalhando com bingo, alfabeto e silabas moveis, análise de jornais /rótulos/conta de água e luz/, elaboração de fichas com palavras grifadas com: c/ç, r/RR, ch/x, s/SS, g/j, s/com som de z, nh/lh, l/u; Elaboração do quadro silábico dentre outras atividades.

\section{LIBERTANDO SONHOS, CONQUISTANDO AUTONOMIA: A APRENDIZAGEM DOS SUJEITOS}

A finalidade da educação é a libertação, a transformação radical da realidade, para torná-la mais humana, para permitir que os homens e as mulheres sejam reconhecidos como sujeitos da sua história e não como objetos. Para isso a educação precisa ser vista não apenas como uma questão só pedagógica, mas também social e política.

Nesse contexto de liberdades Amartya Sen (2000) ressalta que para mudar as realidades de opressões é preciso remover os diferentes tipos de restrições, como nutrição adequada, saúde de qualidade, educação básica, água potável, liberdades políticas e sociais. Isto porque a atuação de sujeitos ativos e que reivindicam melhorias sociais é diretamente proporcional as liberdades de que esses desfrutam.

Dessa forma, a alfabetização não se dá somente no campo cognitivo, mas acontece essencialmente nos campos social e político, tendo em vista que o alfabetizando é desafiado a refletir sobre seu papel na sociedade e também desafiado a repensar a sua história. Nesses termos, o educando passa a questionar as condições que o impediram de ter acesso a escola, moradia digna, saúde, trabalho, etc. Porém, existem casos onde se encontra uma aceitação "cega" das condições de sobrevivência. Casos onde o diálogo se torna quase impossível pois, ao serem questionados os colaboradores tendem a responder que "esta é a vida que deus me deu" ou "deus quis assim". E ao se tentar romper as barreiras construídas surgem frases como: "a essa idade aprender pra quê?" e "papagaio veio não aprende mais a ler".

Na prática, os educandos que não dominam as habilidades da leitura e da escrita desconsideram saberes históricos e cotidianamente construídos e adquiridos, se colocando em lugares de inferioridade no âmbito social, ratificando o processo estruturante de exclusão por meio da naturalização da interdição do seu acesso a ferramentas que garantam os direitos humanos básicos. Assim, se auto denominam incapazes de transpor as barreiras sociais e galgar novos espaços. Contudo, a educação é o principal mecanismo promovedor de mudanças sociais, pois como destaca Brandão (1985, p. 11) a educação possui força, uma vez que:

Ajuda a pensar tipos de homens. Mais do que isso, ela ajuda a criá-los, através de passar de uns para outros o saber que os constitui e legitima. Mais ainda, a educação de crenças e ideias, de qualificações e especialidades que envolvem as trocas de símbolos, bens e poderes que em conjunto, constroem tipos de sociedades.

Acreditando no papel essencial que a educação tem na vida dos sujeitos sociais, bem como sua capacidade de legitimar e construir sociedades, fazer os sujeitos refletirem não apenas a respeito de sua falta de domínio da leitura e da escrita, mas principalmente do quanto isso corrobora para a manutenção das estruturas sociais e as implicações desse processo nas suas vidas, foi o ponto chave do Programa

38 "no processo de busca da temática significativa, já deve estar presente a preocupação pela problematização dos próprios temas, Por suas vinculações com outros por seu envolvimento histórico-cultural” (FREIRE, 1987, p. 5). 
PROELART. Pois, o fato dos sujeitos não se sentirem capazes de aprender algo novo reflete o quadro de absoluta miséria educacional em que se encontram inúmeras pessoas no Brasil.

Durante a atuação do Programa foi possível observar que algumas pessoas passaram por um processo de naturalização, no qual foi introjetado de forma sutil e/ou por meio de espaços sociais desprovidos da garantia dos direitos sociais indispensáveis a condição humana, o estado de aceitação da sua condição social de marginalização. Ou seja, reconhecem os valores e saberes produzidos e administrados pela classe dominante e acreditam que sua exclusão das condições básicas de vida e do processo educativo não poderia ser modificado ou que suas condições de vida derivam de uma predestinação divina, como afirma o relato abaixo:

Estudar pra quê? Eu já tô veio não sirvo pra isso não. Quando era novo não estudei purque tinha qui trabaiá né? Agora não tenho mais cabeça pra isso não. Isso é prus jovens. E pra que vai sirvi isso pra mim? Além do mais minha fia se eu não estudei foi purque deus quis assim. (E.P.S. 2013) ${ }^{39}$.

Para mudar essa perspectiva sobre si mesmos que alguns dos educandos possuíam, demonstramos que o processo de educar não é algo pronto para ser imposto. Assim, pensando o homem e o mundo, Paulo Freire (1987) considera, nesta abordagem que o sujeito é elaborador e criador do conhecimento. 0 autor afirma ainda que o homem é o sujeito da educação. Portanto, não existem senão homens concretos, situados no tempo e no espaço, inseridos num contexto sócio-econômico-político-cultural, enfim num contexto histórico. Com isso, se pode dizer que o homem é um ser situado no e com o mundo.

Dessa forma, a verdadeira educação, para Freire, consiste na educação problematizadora que ajudará a superação da relação opressor-oprimido. Essa educação implica em um constante ato de des-velamento da realidade, e é um esforço permanente por meio do qual os homens vão percebendo criticamente como estão atuando no mundo. Sendo assim, para que se tornassem atos de conhecimento, nos processos de alfabetização de jovens e adultos, buscou-se durante toda a ação do Programa comprometer constantemente os educandos com a problemática de suas situações existenciais.

Nesse processo, o diálogo é desenvolvido ao mesmo tempo em que são oportunizadas a cooperação, a união, a organização, a solução em comum dos problemas. Os educandos participaram em todas as atividades conjuntamente com as ações dos educadores. 0 conhecimento, portanto, é uma construção dialógica diária na qual o educando é sujeito partícipe do processo de aprendizagem onde a educação:

[...] tem de ser forjada com ele, enquanto homens ou povos, na luta incessante de recuperação de sua humanidade. Pedagogia que faça da opressão e de suas causas objeto de reflexão dos oprimidos, de que resultará o seu engajamento necessário na luta por uma libertação, em que esta pedagogia se fará e se refará. (FREIRE, 1981, p. 17).

Portanto, todo aprendizado deve se encontrar intimamente associado à tomada de consciência da situação real vivida pelo educando. Esquece-se, muitas vezes, que grande parte da aprendizagem relacionada à formação de um ser humano acontece espontaneamente, fora da escola, e mesmo a transferência intencional de conhecimento não advém de uma instrução programada. Por esse ângulo a educação é entendida de forma abrangente, pois, engloba todos os processos formativos que se realizam nas práticas sociais relacionadas às diferentes manifestações de convivência humana. É indiscutível a importância que os diferentes níveis de participação possuem na formação dos educandos por meio das experiências vividas em seus cotidianos.

Ao se sentirem parte do processo, os educandos se sentiram valorizados e respeitados pela carga de saber que já possuíam. Isso os impulsionou a querer dominar as áreas da leitura e da escrita para com isso resolver problemas nas mais variadas situações como assinar o nome, ler uma notícia, uma bula de remédio, fazer uma lista, etc. Esse desejo de dominar essas práticas que se constituem como essenciais em suas realidades cotidianas tornou-se primordial para que os sujeitos se sintam participes da sociedade na qual se encontra inserido.

Quero estudar pruque faz falta né? Nos momentos em que preciso fazer compras né? Tem di lembrar tudinho de cabeça, as vezes se esquece. Eu tumbém quiria ler minhas oração. Eu num tive oportunidade de estudar antes,

\footnotetext{
${ }^{39}$ Resposta dada ao questionário realizado pela equipe do PROELART durante visita nas comunidades em 2013.
} 
casei nova. E meu sonho é puder assinar meu nome e num precisar colocar o dedo. Quem num sabe lê é cego fia! Tudo hoje precisa né? (M.A.S. 2013) ${ }^{40}$.

A educação se torna, portanto, instrumento fundamental de emancipação e transformação para as comunidades. Isso porque possibilita uma ampliação dos sonhos, o lugar de sujeito da sua história, bem como um olhar crítico sobre as instituições e sobre o exercício da cidadania. Sabendo que nenhum processo educacional é neutro, já que está sempre na defesa da construção ou permanência de determinados projetos de nação e sujeitos, buscamos possibilitar o respeito e a valorização do lugar social dos educandos, uma vez que, secularmente o movimento tem sido inverso materializando tentativas de imposições de uma 'memória social' sempre elitista.

Mediante o período de atuação do Programa PROELART foi possível constatar que os educandos tiveram um amplo desenvolvimento de aquisição da escrita e da leitura, domínio de oralidade e questionamento e leitura de mundo sobre a realidade social devido as práticas de letramento, pois: "a compreensão do texto a ser alcançada por sua leitura crítica implica a percepção das relações entre o texto e o contexto" (FREIRE, 1989, p. 09). Desta forma, tentou-se ao longo do programa não perder o foco de que no processo de alfabetização, na perspectiva freireana, o ponto de chegada da alfabetização (saber ler e escrever) está associado à elaboração de novos projetos de sociedade e à organização de espaços de participação popular.

Ademais, tendo em vista que o conhecimento só é conhecimento quando partilhado e quando se promove a troca de experiências vividas, foram produzidos alguns artigos científicos para promover a divulgação das ações implementadas e seus respectivos resultados. O Programa teve como resultado as seguintes produções científicas publicadas:

1. Artigo "Diagnóstico da prática de alfabetização em Freire: (re)conhecer o universo vocabular nas comunidades mutirão e invasão do distrito dos mecânicos" CONEDU - Congresso Nacional de Educação Campina Grande, 2014. (Autores: Flaviano Cirino de Souza e Maria José Guerra).

2. Artigo "Memória e aprendizagem: a aquisição e construção do conhecimento na alfabetização de adultos e idosos" CONEDU - Congresso Nacional de Educação - Campina Grande, 2014. (Autores: Jéssica Nascimento Silva e Maria José Guerra).

3. Artigo "O teatro como dispositivo educacional, autônomo e libertador: uma experiência com jovens e adultos da periferia". XVI Encontro Regional dos Estudantes de Letras - Fabrica de marginais: A construção da Identidade Linguística e literária da periferia, UFRJ: 2015. (Autores: Ednalda Ferreira da Silva e Josielio Pereira Marinho).

4. Artigo "Educação, cultura e desenvolvimento local: a contribuição do PROELART para a construção de liberdades” CINTEDI - Congresso Internacional de Educação e Inclusão - Campina Grande, 2014. (Autores: Francinilda Rufino de Souza; Almir Cláudio e José Cassimiro Leite).

5. Artigo "A formação de professores alfabetizadores no programa PROELART". II Seminário Internacional Diálogos com Paulo Freire - Natal, 2014. (Jociano Coêlho).

6. Artigo "As práticas discursivas de alfabetização de professores: uma experiência no programa PROELART”. II Colóquio Nacional de Professores em Educação - Mamanguape, 2014. (Jociano Coêlho).

7. Artigo "Práticas pedagógicas do educador popular na modalidade EJA". CONEDU - Congresso Nacional de Educação - Campina Grande, 2014. (Autores: Rárami Quaresma Zeferino Nascimento e Raísa Eliete Pereira de Almeida).

8. Artigo: "O significado da atividade física para homens e mulheres inscritos no PROELART/UEPB". IV Congresso Internacional de Envelhecimento Humano - Campina Grande, 2015. (Maria José Guerra).

9. Artigo "Alfabetizar Letrando: uma experiência de educação de jovens, adultos e idosos na Vila dos Teimosos - Campina Grande - PB (2013 - 2014)”. Artigo apresentado para obtenção do grau de Bacharel/Licenciado em Pedagogia. 2017. (Juliana Simplício Silva).

A equipe ao longo de toda a ação desenvolvida contou com o apoio dos coordenadores e dos professores educadores que davam suporte aos alunos/educadores. Para isso, foi criado um curso extensivo dentro do programa intitulado: A Construção e e Análise das práticas do Educador Popular: desafios, potencialidades

40 Resposta dada ao questionário realizado pela equipe do PROELART durante visita nas comunidades em 2013. 
e transformação social. Esse curso buscou dar suporte aos alunos bolsistas e atuar conjuntamente para minimizar as dificuldades encontradas para promover o desenvolvimento da prática de alfabetização nas comunidades assistidas pelo Programa.

\section{CONCLUSÕES}

Diante das discussões apresentadas sobre as ações desenvolvidas, nota-se que os fins alcançados satisfizeram aos objetivos do Programa, pois é notável que os educandos participantes do curso adquiriram uma autonomia do saber socialmente construído. Isso foi possibilitado a partir de uma prática pedagógica dialógica, na qual o educando se compreendeu como sujeito social e sujeito dialógico em sala de aula, além de contribuir com a redução do índice de analfabetismo de jovens, adultos e idosos, sendo evidente que aqueles que concluíram o curso mostram ter uma base para utilizar a leitura e escrita em determinadas situações do cotidiano.

Portanto, de forma direita, constata-se impactos de ordem social, tendo em vista a contribuição que o programa proporcionou na melhoria de vida das populações atendidas, já que atuou na melhora da autoestima, formação crítica de sujeitos pensantes e capazes de reivindicar por seus direitos. Bem como promoveu a inserção social de sujeitos por meio do letramento.

Os resultados, também se deram de forma positiva na própria formação dos educadores/bolsistas que tiveram a grata oportunidade de confrontar teoria e prática, refletir e aprimorar suas habilidades e desenvolver novos caminhos para suas futuras atuações docentes. Assim, instigou-os enquanto pesquisadores para não dissociarem em suas práticas o elo que existe entre a pesquisa, o ensino e a extensão. Gerando por sua vez, impactos nas suas ações intelectuais, onde produzem e socializam conhecimentos que visam melhorar as práticas docentes, mas também apontam possibilidades e caminhos que possam ser trilhados com vista a erradicação do analfabetismo no Brasil.

Diante do caminho percorrido ao longo do Programa com seus estímulos e dificuldades, aprendemos sobretudo a respeitar o conhecimento do nosso semelhante, não considerando maior nem menor apenas diferente. As diferenças vividas se deram não apenas no âmbito dos educandos, mas também dos educadores que contou com uma equipe diversificada, ou seja, alfabetizadores que já deram aulas, outros que nunca ocuparam o lugar de professores, assim como diversidade de áreas de conhecimento dos professores universitários. Diversidade dos alunos: jovens e adultos, homens e mulheres, alguns já iniciados na leitura e na escrita, outros que nem conheciam o alfabeto.

Se a diversidade que encontramos acarretou dificuldades, nos permitiu também a troca de experiências e saberes, uma abertura para os pontos de vista de colegas, a explicitação de divergências e até mesmo a revisão de preconceitos. Vale destacar que as estratégias didáticas, os materiais de leitura, os textos de apoio e os materiais de alfabetização recriados pelos alfabetizadores não foram padronizados e se originaram do diálogo, da reflexão e das trocas entre educadores, educandos e formadores. Sem serem criações inéditas, constituem produções pedagógicas nascidas da experiência, das limitações, possibilidades e necessidades do contexto.

Quanto aos aspectos políticos do programa, constatou-se que mais do que ensinar sobre injustiças sociais, educação bancária, opressão, discriminação em função de gênero, cor, local de residência e outros fatores de exclusão, os educadores passaram a enxergar a possibilidade de desenvolver uma educação pautada na humanização, no respeito e na troca de saberes que permitiu refletir não apenas sobre o ato de ensinar, mas principalmente sobre a dimensão política do exercício do magistério. Assim, espera-se que os educandos introduzidos no processo de letramento deem continuidade na busca de mais conhecimentos, que busquem aprimorar-se enquanto sujeitos de ação, que valorizem-se enquanto indivíduos e constituidores de uma sociedade. 


\section{REFERÊNCIAS}

[1] Brandão, Carlos Rodrigues. O que é educação. São Paulo: Abril Cultura; Brasiliense, 1985

[2] Ferreiro, Emília. Cultura escrita e educação: conversas de Emília Ferreiro com Jose Antonio Castorina, Daniel Goldin e Rosa Maria Torres. Tradução Ernani Rosa. Porto Alegre: Artmed, 2001.

[3] Freire, Paulo. Pedagogia da Autonomia: Saberes necessários à prática educativa. São Paulo: Paz e Terra, 1996. 18 Edição №. 3, Vol. 1, jan./dez. 2013. Inserida em: http://www.uel.br/revistas/lenpes-pibid/ .

[4] __ A importância do ato de ler: em três artigos que se completam/ Paulo Freire.- 23a ed. São Paulo: Autores Associados: Cortez, 1989.

[5] _ _ _. Pedagogia do Oprimido. 10. ed. Rio de Janeiro: Paz e Terra, 1987.

[6] __. Ação cultural para a liberdade. 5. ed. Rio de Janeiro: Paz e Terra, 1981.

[7] Guerra, Maria José. Experiência e vida, no domínio da aprendizagem necessária, em EJA: o que diz a pesquisa de professor-aluno da Alfasol. In: Revista da Alfabetização Solidária. São Paulo, 2006, v.6, n.6. 


\section{Capítulo 22}

\section{A educação escolar como direito dos povos indígenas: A conquista das crianças Sateré- Mawé}

\section{Elenice Maria Farias Mourão de Menezes \\ Simone Souza Silva}

Renner Douglas Gonçalves Dutra

Resumo: Este estudo resulta de uma pesquisa que investigou o impacto sociocultural na aprendizagem de crianças Sateré-Mawé em uma escola regular urbana em Parintins-AM. Trata-se de um estudo relevante, especialmente para professores que buscam aperfeiçoar sua didática e compreender as crianças em suas especificidades, ajudandoas a minimizar o impacto sociocultural existente no processo de aprendizagem das mesmas em relação à estruturação do pensamento, a partir da segunda língua. A pesquisa é de natureza qualitativa, com apoio da abordagem dialética e técnicas de documentação indireta e documentação direta. Para melhor compreensão, o estudo trata da educação escolar como direito e uma conquista dos povos indígenas no Brasil e traz à tona os diversos fatores que induziram os Saterés a perceberem a necessidade do aprendizado escolar e inserir suas crianças em escolas próximas de suas comunidades. Ao sair do seio de sua comunidade indígena, as crianças passam por grandes mudanças de adaptações ao adentrar no espaço urbano, rompendo um pouco das suas tradições, ocorrendo assim o impacto sociocultural devido as crianças, seus pais e escolas não estarem preparados para os desafios que surgem nesse processo de adaptação entre ambos. E constitui um dos motivos que levam os povos indígenas a lutarem pela Escola Indígena nas comunidades em que estão inseridos, desenvolvendo uma educação melhor e mais significativa, com métodos e conteúdos apropriados e direcionados conforme a legislação educacional. Os resultados do estudo apontam que ainda há dificuldades em lidar com as diferenças étnicas e sociais no espaço escolar no Brasil e o quanto se faz necessário conhecer a história e desconstruir o olhar etnocêntrico exacerbado em relação aos povos indígenas que existem entre nós.

Palavras-chave: Impacto Sociocultural, Escola Indígena, Educação, Intercultural, Crianças Indígenas. 


\section{INTRODUÇÃO}

A motivação para o desenvolvimento desta pesquisa iniciou com a participação em uma aula de Antropologia e Educação na Amazônia do Curso de Pedagogia da Universidade do Estado do Amazonas CESP/UEA, onde discutimos a temática de "Como o índio era visto? Exótico". Buscamos compreender como era o ambiente escolar onde as crianças indígenas estavam inseridas, visto que elas recebiam um olhar diferente em relação às outras não indígenas.

Trata-se de um estudo relevante, especialmente para professores que buscam aperfeiçoar sua didática e compreender as crianças em suas especificidades, ajudando-as a minimizar o impacto sociocultural existente no processo de aprendizagem das mesmas em relação à estruturação do pensamento, a partir da segunda língua. Nossas inquietações são muitas, no entanto, este estudo buscou compreender como as crianças indígenas conseguem ultrapassar essa problemática que está ligada ao encontro de duas sociedades diferentes, com culturas diversificadas, cujas diferenças afetam, sobremaneira, no processo de aprendizagem cognitivo das crianças Sateré- Mawé.

O lócus da pesquisa escolhido foi uma Escola Municipal de Parintins-AM, cujos sujeitos foram as crianças matriculadas nos anos iniciais do Ensino Fundamental. Para a pesquisa nos utilizamos das orientações propostas por Martins e Theóphilo (2007, p. 137), que nos ensinam "que os dados coletados devem ser predominantemente descritos; é necessário registrar a descrição [...] de pessoas, de situações e de acontecimentos, de reações, inclusive transcrições de relatos".

0 estudo parte da compreensão de que toda criança tem seus direitos, merece respeito como cidadã e deve ser aceita, inclusive, em seus aspectos socioculturais. Afinal, assim como todas as crianças, as crianças indígenas também têm seus direitos, que são amplos, principalmente no que trata a educação.

O Brasil é conhecido como um país sem preconceito e discriminação (VENERE, 2008). No entanto, em pleno século XXI ainda é possível esbarrar em conflitos referentes às diferenças de um cidadão, seja pelo status financeiro, raça ou cor.

Em Parintins, no Amazonas há crianças Hiskarianas e Saterés - Mawé que frequentam as escolas urbanas situadas na sede do município. E é para as crianças Sateré-Mawé que se volta o olhar desta pesquisa, devido à grande frequência das mesmas nas escolas do município de Parintins.

Em relação às crianças indígenas, os fatores que levam ao impacto sociocultural são diversos e, inclusive, podem interferir no aprendizado dessas crianças, principalmente das que frequentam a escola urbana, onde passam a conviver com uma cultura totalmente diferente da sua.

Diante disso surgiu a inquietação em saber como se dá o impacto sociocultural no espaço escolar no processo cognitivo das crianças Sateré-Mawé. Sabe-se que os desafios são amplos: financeiro, a saúde, transporte, moradia, alimentação, o convívio com os não indígenas entre outros, uma das questões que a inclusão discute atualmente, a aceitação das crianças indígenas em relação ao outro e isso deve ser primordial para se trabalhar no espaço escolar, para que todos possam perceber e reconhecer seus valores e a igualdade entre si.

E a escola é fundamental para haja essa formação cidadã e tem o dever de integrar e principalmente incluir todas as crianças numa socialização igualitária, ou seja, para que nenhuma criança seja discriminada ou excluída de sua vida social com um todo. Ao trabalhar métodos que possibilitem construir valores independente da criança ser indígena ou não, a escola estará respeitando a luta histórica dos indígenas que lutaram por seus direitos, inclusive, de ter e estar na escola. Da mesma forma, a escola estará fortalecendo os avanços socioculturais relacionados à sociedade e cultura como um todo, abrindo possibilidades para a valorização das lutas e também vitórias alcançadas, de forma que todas as crianças reconheçam seus valores e sua identidade independente da raça, da cor ou da cultura que cada uma carrega consigo.

Para tanto, consideramos eminentemente necessário compreender como se deu a luta pelo direito à educação escolar dos povos indígenas Sateré-Mawé, no Município de Parintins.

\section{METODOLOGIA}

Esta pesquisa é de natureza qualitativa, pois conforme nos esclarece Flick (2009, p. 23), os aspectos essenciais desta pesquisa "consistem na escolha adequada de métodos e teorias convenientes; no reconhecimento e na análise de diferentes perspectivas; nas reflexões dos pesquisadores a respeito de suas pesquisas como parte do processo de produção de conhecimento". Para nos aprofundarmos nessa 
temática optamos pelo método de procedimento Histórico, por meio do qual investigamos o passado dos indígenas com a intenção de compreender como eles são vistos atualmente para que possamos refletir em uma didática adequada para as crianças indígenas matriculadas em uma escola regular. Utilizamos ainda os pressupostos da pesquisa bibliográficas.

\section{RESULTADOS E DISCUSSÕES}

"Nossa cultura ameríndia teu povo engrandece das lutas travadas, teu solo não esquece e a mãe natureza por ti viverá, Sateré. A humanidade reflete teu rosto cansado das vidas vividas, do fardo pesado, histórias profundas que tens a contar, Parintintin, Tupinambá [...] (MEDEIROS, 1998).

A letra da toada de boi-bumbá "Lamento Ameríndio" composta por Tony Medeiros em 1998, retrata as lutas travadas pelos indígenas Sateré-Mawé, que perdurou por muitos anos por seus direitos, mas infelizmente como na maioria das leis no Brasil, estas nem sempre são colocadas em prática. Para compreender esse processo de luta histórica apresentamos, de forma breve, a Lei № 6.0001, de 19 de dezembro de 1973, a qual trata dos direitos conquistados pelos indígenas, especificamente no que diz respeito à educação, como destaca Azevedo (2016, p. 118-120):

Lei № 6.0001, de 19 de dezembro de 1973.

\section{Título I}

\section{Dos Princípios e Definições}

- Art. 1o Esta lei regula a situação jurídica dos índio ou silvícolas e das comunidades indígenas, com o propósito de preservar a sua cultura e integra-los, progressivamente e harmoniosamente, a comunhão nacional.

- Art. 2o / III - respeitar, ao proporcionar aos índios meios para o seu desenvolvimento, as peculiaridades inerentes a sua condição. / VI- respeitar, no processo de integração do índio à comunhão nacional, a coesão das comunidades indígenas e seus valores culturais, tradições, usos e costumes.

Quanto aos critérios que definem um cidadão indígena no Brasil, o artigo 3o da Lei № 6.0001/1973 prevê:

Art. 3ํㅜ Para efeito de lei, ficam estabelecidas as definições a seguir discriminadas:

I - Índio ou Silvícola - É todo indivíduo de origem e ascendência pré- colombiana que se identifica e é identificado como pertencente a um grupo étnico cujas as características culturais o distinguem da sociedade nacional;

II - Comunidade indígena ou Grupo Tribal- é um conjunto de famílias ou comunidades indígenas, quer vivendo em estado de completo isolamento em relação a outros setores da comunhão nacional, quer em contatos intermitentes ou permanentes, sem contudo estarem neles integrados.

Ainda com relação à educação, Azevedo (2016, p. 28) traz a Lei № 6.0001, de 19 de dezembro de 1973, a qual destaca que:

\section{Título V}

\section{Da Educação, Cultura e Saúde}

- Art. 47. É assegurado o respeito ao patrimônio cultural das comunidades indígenas, seus valores artísticos e meio de expressão.

- Art. 48. Estende-se à população indígena, com as necessárias adaptações, o sistema de ensino em vigor no país.

- Art. 49. A Alfabetização dos índios far-se-á na língua do grupo a que pertençam e em Português, salvaguardando o uso da primeira.

- Art. 50. A educação do índio será orientada para a integração na comunhão nacional mediante processo de gradativa compreensão dos problemas gerais e valores da sociedade nacional, bem como do aproveitamento das suas aptidões individuais.

- Art. 51. A assistência aos menores, para fins educacionais, será prestada, quando possível, sem afasta-los do convívio familiar ou tribal. 

aculturação.

Art. 52. Será proporcionada ao índio a formação profissional adequada, de acordo com seu grau de

- Art. 53. 0 artesanato e as industrias rurais serão estimulados, no sentido de elevar o padrão de vida do índio com a conveniente adaptação às condições técnicas modernas.

- Art. 54. Os índios tem o direito aos meios de proteção à saúde facultados à comunhão nacional.

Parágrafo único. Na infância, na maternidade, na doença e na velhice, deve ser assegurada ao silvícola, especial assistência dos poderes públicos, estabelecimentos a esse fim destinados.

Na mesma direção, trazemos alguns pontos da Lei de Diretrizes e Bases no 9.394/1996 - LDB, a qual prescreve no Título VIII- Das disposições Gerais direitos voltados para a Educação Indígena:

Art. 78. O Sistema de Ensino da União, com a colaboração das agências federais de fomento à cultura e de assistência aos índios, desenvolverá programas integrados de ensino e pesquisa, para oferta de educação escolar bilíngue e intercultural aos povos indígenas, com os seguintes objetivos:

I- $\quad$ Proporcionar aos índios, suas comunidades e povos, a recuperação de suas memórias históricas; a reafirmação de suas identidades étnicas; a valorização de suas línguas e ciências.

II- Garantir aos índios, suas comunidades e povos, o acesso às informações, conhecimento técnico e científicos da sociedade nacional e demais sociedades indígenas e não índias.

Art. 79. A união apoiará técnica e financeiramente os sistemas de ensino no provimento da educação intercultural às comunidades indígenas, desenvolvendo programas integrados de ensino e pesquisa.

§1ํo Os programas serão planejados com audiência das comunidades indígenas.

§2 Os programas a que se refere este artigo, incluídos nos Planos Nacionais de Educação, terão os seguintes objetivos:

I - fortalecer as práticas socioculturais e a língua materna de cada comunidade indígena;

II - manter programas de formação de pessoal especializado, destinado à educação escolar nas comunidades;

III - desenvolver currículos e programas específicos, neles incluindo os conteúdos culturais correspondentes às respectivas comunidades;

IV - elaborar e publicar sistematicamente material didático específico e diferenciado.

§3ํㅡㄹ No que se refere a educação superior, sem prejuízo de outras ações, o atendimento aos povos indígenas efetivar -se -á, nas universidades públicas e privadas, mediante à pesquisa e desenvolvimento de programas especiais.

Conforme exposto, há leis que tratam dos direitos dos povos indígenas no que concerne à educação, as quais precisamos conhece-las como forma de salvaguardar os direitos conquistados. Afinal, atualmente vivemos um momento de retrocesso em termos de perdas de direitos duramente conquistados. E, como nos ensina Medeiros (2009), "a terra não pode jamais ser um campo de guerra":

"Kaiapó, Andirá, Sapopé, nações guerreiras do Tronco Tupy, teu povo, teu chão, tua gente, Tupã dia e noite suplica por ti, tua terra não pode jamais ser um campo de guerra [...]” (MEDEIROS, 2009).

A toada de autoria do compositor Tony Medeiros em 2009, traz à tona a reflexão quanto às lutas dos povos indígenas. E no que trata à educação, esta questão não é diferente, pois devido a fatores de ordens diversas, os Saterés passaram a perceber a necessidade do aprendizado escolar, despertando o interesse em inserir suas crianças em escolas próximas de suas comunidades.

[...] depoimentos de familiares de crianças indígenas que, por motivos diversos, têm procurado essas escolas para a educação formal de seus filhos, fato este que vem ocorrendo cada vez mais em idade precoce. Diante das novas demandas da sociedade urbana e que estas famílias inserem, os pais ou os responsáveis experimentam a ruptura dos seus filhos com a cultura indígena tradicional e a inserção em uma nova cultura, o que vem causando preocupação e gerando angústia diante do despreparo da escola urbana em conviver com a diferença (VENERE; VELANGA, 2008, p. 176).

Ao sair do seio de sua comunidade indígena, as crianças passam por grandes rupturas, mudanças de adaptações, especialmente, ao adentrar no espaço urbano, rompendo, inclusive, com traços de suas tradições. Afinal, nem sempre as crianças, seus pais e principalmente as escolas estão preparadas para o 
enfrentamento de questões sociais e culturais que emergem em meio a esse processo de adaptação entre ambos. Essa adaptação torna-se importante e influi no avanço na educação e no aprendizado das mesmas.

0 impacto sociocultural pode estar presente entre as crianças saterés no âmbito escolar. Trata-se de crianças que não são acostumadas a cumprir regras e normas em excesso, visto que são criadas em sua comunidade, de maneira livre e natural e seus pais não interferem em seus aprendizados que acontecem de maneira espontânea.

[...] nas comunidades indígenas, muito raramente vamos encontrar punições, restrições à liberdade, opressões por parte dos mais velhos, que sempre demonstram grande tolerância, paciência e bom humor em relação às suas crianças. Os pais são os grandes responsáveis pela sua socialização, mas os parentes e as pessoas do convívio também se empenham para integrá-las à vida comunitária, transmitindo valores e tradições. Na verdade, a educação infantil no interior das comunidades indígenas não chega a ser um problema, ela ocorre espontaneamente e de maneira prazerosa, interativa, natural (VENERE; VELANGA, 2008, p. 179).

Ao adentrar o espaço escolar, existe uma mudança em vários aspectos da convivência com e das crianças indígenas, talvez por algumas escolas não estarem preparadas para recebe-las. Há uma necessidade de se ter orientações para toda comunidade do espaço escolar, de como receber, agir e ensinar as crianças indígenas, ou seja, como lidar com culturas diferentes, pois é na escola que se trabalha os aspectos culturais, articulados aos conteúdos escolares. E como argumenta Ferreira (2011, p. 03):

[...] o investimento no estabelecimento do diálogo na capacidade de resolução do conflito intercultural é o alicerce, é o que justifica mesmo a existência dessa escola, é o que dá a ela relevância política. Será que em um mundo tão globalizado como o de hoje, nossas escolas - principalmente aquelas nos grandes centros urbanos - também não deveriam adotar mais categoricamente a interculturalidade como tema transversal, de modo a melhor preparar nossas crianças e jovens para o sempre difícil encontro com o outro, com o diferente?

Essas e outras reflexões são pertinentes e necessárias no espaço escolar. Daí o sentido da luta dos povos indígenas por uma educação melhor e mais apropriada, principalmente nas comunidades indígenas, de modo que evite a evasão de suas áreas.

Para tanto, a proposta da escola indígena tem como foco a Educação, o métodos e conteúdos apropriados e direcionados, conforme a legislação educacional. Trata-se de uma proposta que pensa o trabalho na escola indígena através da interculturalidade, e o mais interessante é que além dos conteúdos de aprendizado de uma escola regular, nesta são trabalhados a língua materna de uma comunidade indígena específica, a arte, a cultura desses povos e suas crenças, para que estas não se percam no tempo, correndo o risco de serem extintas em algum aspecto.

Sobre isso, Repetto e Souza (2007, p. 38) trazem a fala de um indígena que expressa o sentido da luta por seus direitos:

Nós indígenas temos direito a conhecer nossas línguas e culturas e a escola não pode ser mais um lugar de imposição e submissão. Deve ser um espaço de reflexão e valorização da diversidade e do contexto intercultural, um espaço de libertação. Deve haver o ensino de nossas línguas: o macuxi, o wapichana, o taurepang, o ye kuana, dentre outras. Mas também o estudo da história dos povos indígenas e da colonização ou invasão dos "brancos" nos territórios indígenas e estudar e repudiar as violências e imposições que sofremos na história de Roraima e do Brasil. É importante estudar os conteúdos culturais indígenas (tradições culturais, história, literatura, artesanato, medicina tradicional, etc.).

Essas escolas são de suma importância para os povos indígenas, no entanto esses povos não querem apenas o atendimento em suas comunidades indígenas, querem ir além, e assegurar o que está previsto em lei. Exemplo disso são algumas comunidades Sateré- Mawé de Parintins, onde já existem escolas, embora algumas ainda atuando de acordo com a Escola regular, mas há outras em processo de quebrar esses paradigmas tornando-a em Educação Escolar Indígena.

Por outro lado não podemos ignorar que embora haja a luta escola por escolas na área indígena, muitos indígenas migraram para os centros urbanos, aumentando a demanda de indígenas em algumas cidades e municípios brasileiros, como argumentam Repetto e Souza (2007, p. 38):

[...] questionamos a legislação escolar indígena (Resolução 03/1991 CNE/MEC), que considera e define a escola indígena apenas como aquela localizada em terra indígena. Ora, fomos expulsos de nossos territórios e confinados a viver na cidade nos bairros periféricos. Agora podemos e queremos construir escolas indígenas na cidade, o que implica a devida consignação de recursos para os alunos indígenas. 
Afinal, a constituição Federal do Brasil garante aos povos indígenas o uso de seus próprios processos de construção e de criação de conhecimentos e não define que esteja limitada apenas às terras indígenas. É um direito reconhecido a todos os povos indígenas, inclusive a nós, que moramos na cidade.

Os estudos apontados por Repetto e Souza (2007) não diferem da realidade do Município de Parintins, onde há a necessidade de uma Escola Indígena para atender as crianças Sateré-Mawé, as quais manifestam enormes dificuldades, ao adentrarem numa escola urbana regular, onde permanecem caladas, inibidas, impostas a receber apenas a uma cultura onde os aspectos privilegiados são os saberes científicos, sem relação com os saberes de seus povos. Para tanto, trabalhar a interculturalidade é fazer a transmissão cultural e a troca de culturas, de experiências, onde o aspecto cultural seja considerado e articulado aos saberes escolares, tornando rico o espaço escolar, respeitando os direitos que foram conquistados pelos povos indígenas.

\section{CONCLUSÃO}

Este estudo buscou investigar o impacto sociocultural na aprendizagem de crianças Sateré-Mawé em uma escola regular urbana em Parintins-AM.

A partir dos resultados deste estudo, podemos inferir que a escola, juntamente com seus professores deve discutir o que é melhor para a construção de uma sociedade inclusiva, onde devemos respeitar e entender a cultura de outros povos como contribuição para o fortalecimento de sua identidade.

Afinal, o estudo mostrou que a dificuldade de lidar com as diferenças étnicas e sociais, ainda persiste na atualidade. Cabe à escola trabalhar essas questões de forma que cada criança, cada estudante compreenda a importância de não olhar o outro de maneira preconceituosa, pois, ao sair do seio de sua comunidade indígena, as crianças passam por grandes mudanças de adaptações ao adentrar no espaço urbano, rompendo um pouco das suas tradições, ocorrendo assim o impacto sociocultural devido as crianças, seus pais e as escolas não estarem preparados para os desafios que emergem nesse processo de adaptação entre ambos.

Os resultados do estudo apontam que ainda há dificuldades em lidar com as diferenças étnicas e sociais no espaço escolar no Brasil e o quanto se faz necessário conhecer a história e desconstruir o olhar etnocêntrico exacerbado em relação aos povos indígenas que existem entre nós.

\section{REFERÊNCIAS}

[1] Azevedo, Marlon Jorge Silva de. Minidicionário Trilíngue Indígena Sateré-Mawé em Libras e Língua Portuguesa. Universidade do Estado do Amazonas- UEA, 2015.

[2] Flick, Uwe. Introdução à pesquisa qualitativa. Uwe; tradução Joice Elias Costa. 3. ed. Porto Alegre: Artmed, 2009.

[3] Ldb: Lei de diretrizes e bases da educação nacional. Brasília: Senado Federal, Coordenação de Edições Técnicas, 2017.

[4] Ferreira, Edna. CECIs: um desafio intercultural. Anais Eletrônicos IX Encontro Nacional dos Pesquisadores Ensino de História- Florianópolis / SC. 2011.

[5] Martins, G.A; Theophilo, C. R. Metodologia da Investigação Científica para Ciências Sociais Aplicadas. São Paulo: Atlas, 2007.

[6] Medeiros, Tony; Ajuri. Lamento Ameríndio - Tambores Do Tempo. In: CD Boi-Bumbá Garantido: 500 anos do passado para construir o futuro. Rio de Janeiro: Polygran, 1998.

[7] Medeiros, Tony; Pontes, Alex. Andrada, Mario de. Tronco Tupy. In: CD Boi-Bumbá Garantido, 2009.

[8] Repetto, Marxim; souza, Eliandro Pedro de. Diagnóstico da situação dos indígenas na cidade de Boa VistaRoraima / Organização dos Indígenas da Cidade; ilustrações de Bartolomeu da Silva Tomas. Gráfica Ióris, Boa Vista: 2007.

[9] Venere, M. R; Velanga, C.T. A criança indígena e a educação infantil: as complexas relações entre a cultura e a escola na cidade. Tellus, ano 8, n. 15, p. 175-191, Campo Grande - MS: jul. / dez. 2008. 


\section{Capítulo 23}

\section{Escolarização e objetos: a troca no sentido das miçangas entre os Guarani- Mbyá do Rio de Janeiro}

\section{Danielle Bastos Lopes}

Resumo: Este artigo analisa a produção de objetos e a relação com a escolarização dos povos Guarani - Mbyá, sociedades do tronco Tupi, localizados no estado do Rio de Janeiro. Trata-se de uma etnografia que analisa os objetos e amuletos sagrados e que tem na relação com a escolarização uma relação com o Nhandereko ete, isto é, o conjunto de elementos e cosmologias que pertencem aos "modos de vida Guarani". Aproveitamos para falar dos grafismos produzidos com miçangas e extraídos de árvores específicas. A escolarização, nesse contexto, não se resume a documentos escritos ou protocolares, mas a toda produção de sentido que a escola e a vida dos objetos suscitam. 0 artigo divide-se em três eixos centrais: (1) a contextualização histórica Guarani, (2) a localização dos tekohas (território) no Rio de Janeiro e, (3) por fim, a reflexão sobre os objetos.

Palavras Chave: Currículo, Objetos, População Mbyá (Guarani). 


\section{INTRODUÇÃO}

Nas terras baixas da América do Sul a população Guarani é considerada a segunda maior população, somando perto de $9 \%$, cerca das 800 mil populações distribuídas nos centros urbanos, mercados e paisagens da América Latina (FUNASA, 2010; UNESCO, 2017). Os Guarani aparecem também mapeados, cabe destacar, nos territórios do Paraguai, Uruguai, Bolívia e Argentina. Na maioria das pesquisas estão divididos em três (sub) grupos ${ }^{41}$ distintos e interligados entre si, como os Nhandeva, Kaiowá e Mbyá, incluindo os chiriguanos, habitantes do Paraguai e Bolívia, localizados próximos às fronteiras do Império Inca (SCHADEN, 1954; LADEIRA, 2007; LITAIFF, 1999). Nesse artigo particurlamermente, analiso o povo Guarani - Mbyá, localizados ${ }^{42}$ no interior do estado do Rio de Janeiro.

Egon Schaden (1954) e depois Meliá (2010), sugerem que existiram até a Conquista, dez milhões de indígenas, além de dois milhões de populações Guarani, quantificadas as culturas e denominações equivocadas do período jesuítico. 0 quadro desemboca no genocídio que foi a sociedade civil colonial portuguesa - espanhola e os pós - contatos dos conseguidos séculos (RIBERO, 1977). Povos como os Tupi, por exemplo, herdaram não só o holocausto, como a morte por causas epidêmicas via disseminação de pestes e contágios, como a varíola, a febre amarela, malária, entre outras doenças disseminadas entre os anos 1950 - 1960 (SOUZA LIMA, 2012).

Na obra "Aldeamentos Indígenas do Rio de Janeiro", sobre a temática da escolarização, Bessa Freire (2009) aponta que no século XVI, os aldeamentos vivenciaram a fundação dos primeiros colégios internos para índios na região atlântica. Foram construídas escolas de "ler, escrever e contar", em malocas específicas para essa finalidade. A localização dos colégios era usualmente no centro dos aldeamentos, convivendo com porcos do mato, rebanhos de queixadas e outros animais.

Tem muitos anos que a gente está aqui já. Então nós fomos pro Espírito Santo, retornamos pra cá de novo (Paraty). Entendeu? Depois do sul fomos direto pro Espírito Santo, ficamos em São Paulo, não era, acho que não era o lugar pra gente ficar. Passamos em vários lugares, várias aldeias, e o que, andava, andava até que fomos pro Espírito Santo, fomos lá em Vitória, ficamos numa aldeia lá, em Boa Vista. Autora: Boa Esperança. Roque: Lá em Boa Esperança ficamos um ano só, e a falecida vovó ainda era viva ainda. Morava lá né, ai indicou essa aqui (Teko - Território) pra cá, pra voltar, indicou para nós, para o meu pai, ai viemos pra cá. Ficamos buscando aqui, ali não tinha ninguém na época né. Só tinha uma casa lá embaixo que era de um pessoal, até que conseguimos, demarcar essa área para nós. E estamos aqui até hoje. Todo mundo gosta daqui. É homologado, aqui é, ninguém nos tira. (Roque, Reserva de Itatim, Paraty, RJ, entrevista concedida à autora em fevereiro de 2015)

0 estado do Rio de Janeiro permaneceu sem população ameríndia, portanto, por toda a primeira metade do século XX até que um movimento de redes indígenas ocupou a região nos anos 1950. Centenas de comunidades teriam migrado do Vale do Rio Paraná à Serra da Bocaina, construindo malocas em uma antiga região habitada pela população Goianá, às margens do Parati-Mirim (LADEIRA, 2007; LITAIFF,1999). Nessa lógica, os Guarani, denominados apressadamente como mbyá (gente), teriam sido contactados exclusivamente em 1972, devido a abertura da estrada Rio - Santos.

\section{MUNDO POSSÍVEL, MIÇANGAS, AMULETOS DE PROTEÇÃO}

Entre os Guarani os maiores e melhores ensinamentos concentram-se na Casa de rezas (Opy) e nos xamãs (BENITES, 2012; DA SILVA, 2015; SILVA, 2013). 0 ensino individual que é repassado do xamã para o indivíduo, não pode ser transmitido a outros membros, o que desestrutura a lógica da aprendizagem coletiva, comumente aplicada em escolas não indígenas.

\footnotetext{
41 Esta é a classificação comum, embora não corresponda necessariamente aos etnônimos utilizados pelos Guarani de forma geral (MELIÀ, 2010, 2011). No Paraná, os Nhandeva se nomeiam Avá-Guarani ou Avá-Katú-Eté, os Kaiowá, são tidos como Pãi- Tavyterã ou Ava Kaiowá.

42 As 7 Terras Indígenas (TIs) concentram-se em : (1) T.I Bracuí (Angra dos Reis); (2) T.I Araponga (Paraty); (3) T.I Itaxim (Paraty) ;(4) T.I Arandú Mirim -Saco de Mamanguá (Paraty); (5) T.I Rio Pequeno (Paraty); (6) T.I Tekoa Mboyty (Maricá) ;(7) T.I Caminho do Céu (Itaipu). Dos sete territórios apenas três estão homologados, Bracuí, homologada em 1995, Araponga e Itaxim homologadas em 1995 e 1996. (CPI-SP, 2014). Ressalto que utilizarei, em vezes, a palavra $<$ aldeia>, por ser a forma frequente (em português) com que os Guarani se referem às suas terras.
} 
Todos os objetos e amuletos são produzidos por mulheres e podem conter padrões agrupados, como a cobra jararaca (mboi para) ou formas de coração (Py'a Tytya) e outros simbolismos. Os quadrados consagram a cosmologia representada por Nhanderu (Deus e creditador Guarani) que expressa mais especificamente, a proteção e o resguardo.

Appadurai ([1986] 2014) argumenta que os objetos que expressam constituições estéticas e servem de tração religiosa, são proibidos de ocupar o lugar de mercadoria (STRATHERN,1999, 2014). As mercadorias, de um modo geral, despertam de modo independente o interesse de diversos tipos de pesquisadores. Como observou Marilyn Strathern $(1999,2014)$, a troca exprime o valor e não o contrário, não é necessariamente a informação, mas a própria troca sugere como as relações se estabelecem no território. Podemos dizer que a escola e os territórios tanto quanto as miçangas, nesse sentido, constituem uma negociação ${ }^{43}$ (BHABHA,1994).

O primeiro objeto que recebi foi uma pulseira (poapy reguá), com losangos e semicírculos esculpidos. Mais tarde, soube que o losango, representa o padrão cobra jararaca (mboi para - cobra grande), que refere-se a um grafismo chamado Vida Longa (teko puku), cujo desenho é oferecido para que uma pessoa viva por muitos anos dentro de um grupo ou família. De acordo com Da Silva (2015), há precisamente dois tipos de grafismos que um Guarani produz ao longo da vida: Ypará, com significados mitológicos e Ta`anga, que registra os significados físicos, estes últimos representando simbologias que não associam-se à representação mítica.

Em relação aos desenhos sagrados, existem três tipos de grafismos: (1) Ypara Korava'e, em forma de losango; (2) Ypara kora jo'ava'e, em modelo de cruz; e (3) Ypara Ryxyva'e, em formato de S. Existem também outras variações com formas animais, como Ipara tanambi pepo, o esqueleto da asa de mariposa, que representa respeito e liberdade; cobra coral (mboi pytã), que exprime a cura do corpo e do espírito, cobra jararaca (mboi para), referindo-se às condições do parentesco e asteriscos, para os homens que conseguiram trazer a caça abatida para o consumo.

Todos esses modelos contêm padrões, que não fogem às três linhas de repetição (DA SILVA, 2015; CAMPOS, 2012). 0 cipó Imbé produtor da tinta escura e Katiguá que extrai o pigmento avermelhado, não são encontrados facilmente. A tinta acrílica está vinculada à troca mercantil para produzir e fomentar o que entende-se como a "vida social dos objetos" (APPADURAI, [1986] 2014). Na maioria das sociedades ditas não ocidentais, descobrirmos uma estrutura taxionômica que muda de acordo com os sentidos colocados pelos compradores. Na tinta acrílica utilizada pelos Guarani, apesar da escassa matéria prima, por exemplo, o produto é substituído, mas os objetos permanecem sagrados. Em "A vida social das coisas", Arjun Appadurai ([1986] 2014) procurou desconstruir o etnocentrismo de que as populações do Oriente não podem estabelecer relações comerciais sem perder suas culturas por exemplo.

Em Itaxim a troca ocorre por venda de objetos e rituais, propriamente ditos. Como diria Chakrabarty (1992, 2012), as coisas não estão divorciadas da capacidade das pessoas de agir e nem do poder de comunicação dos objetos. Não existe nesse sentido, um mundo de peças inertes e sem linguagem (APPADURAI, [1986] 2014; BHABHA, 2013; CHAKRABARTY, 1992, 2012). Entre os Mbyá, os valores e o apreço às mercadorias expressam "mundos possíveis" que circulam de uma família para outra.

A seguir Elaí analisa os objetos produzidos pelas mulheres vendidos nos mercados de Paraty:

Eu aprendi com a minha mãe. Ela produz com miçanga. Não tinha muito, mas eu comecei a aprender. Começei com onze anos. [...]. Eu deixo as crianças andando e faço de manhã até a noite. Eu faço almoço e depois faço a miçanga. Na verdade, as miçangas são minhas únicas fontes de renda. As mulheres mais idosas não podem vender, então outras pessoas vão vender para elas. Hoje em dia, muitos pedem os ta'anga, que são outros desenhos; não são os nossos tradicionais... [...] Muitos são de times, Botafogo, Flamengo. Isso os mais jovens, né [sic].

\section{Autora: E os Ypará [grafismo mítico]? Todos utilizam?}

Utilizamos. Os homens usam pulseiras de times, como proteção. Roque [referese ao seu marido cacique de Mamanguá] não entra para o mato sem o colar que a mãe deu a ele. Ainda usamos, mas tem enfraquecido muito. As pulseiras utilizam tanto os homens como as mulheres. Já os Oky Ra'anga [paus de chuva]

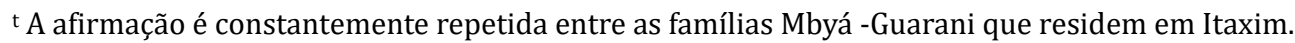


e os arcos e flechas pequenos fazemos mais para os juruá [branco] mesmo. Os nossos arcos são grandes. Não utilizamos esses objetos. Fazemos só para os brancos (Elay. Entrevista concedida em julho de 2014).

Figura 1 - Pulseira (poapy reguá) padrão Ypará (desenhos míticos). Aldeia Itaxim - Paraty- RJ

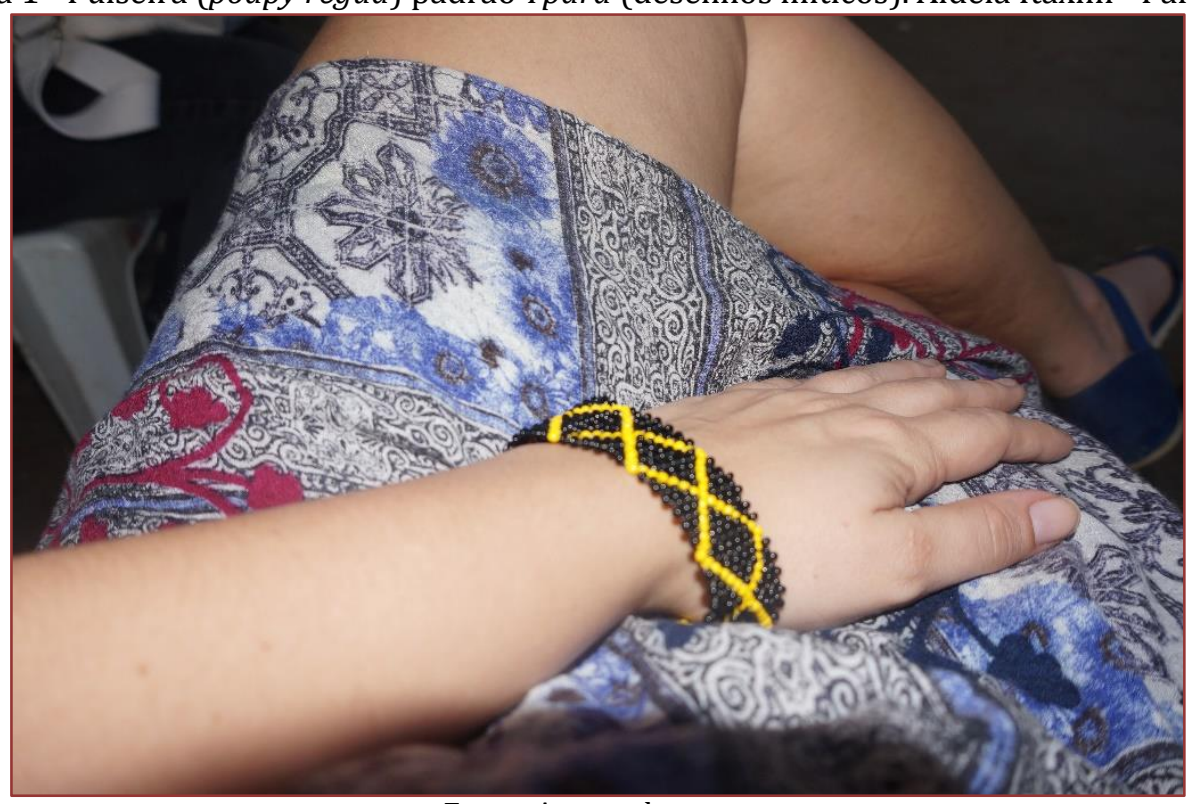

Fonte: Acervo da autora

Figura 2 - Elay trança miçangas. Aldeia Itaxim - Paraty- RJ

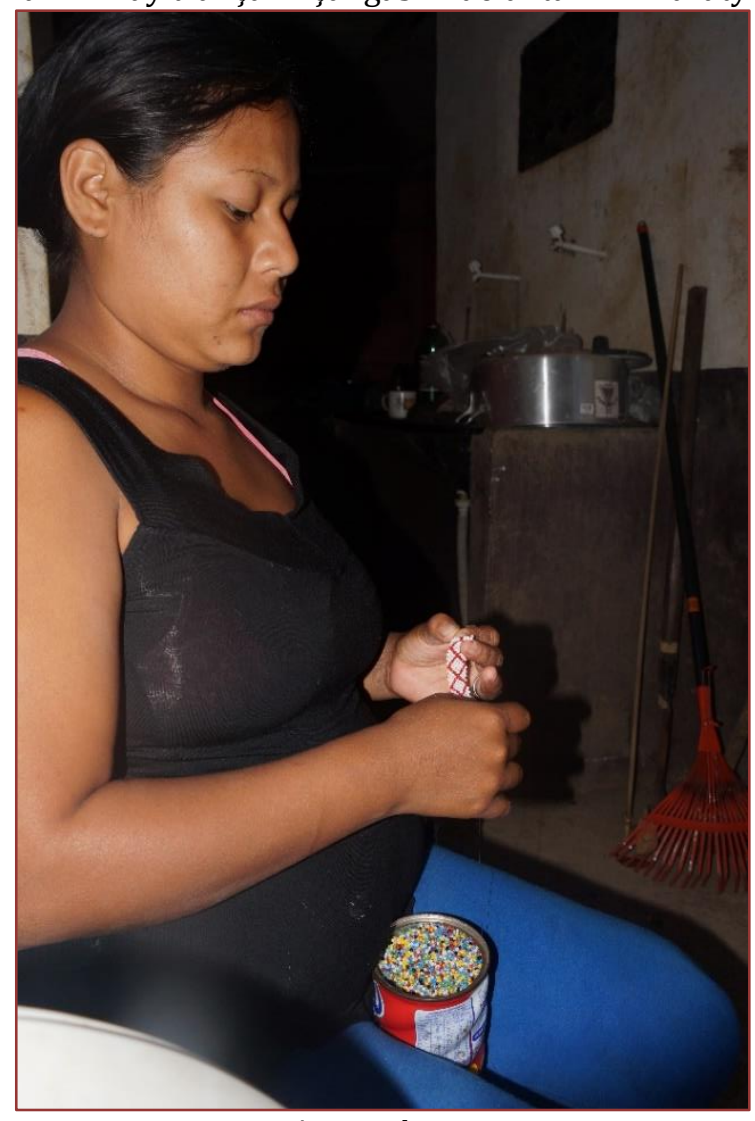

Fonte: Acervo da autora ${ }^{44}$

${ }^{44}$ Informo que todas as imagens utilizadas neste artigo foram autorizadas à pesquisadora por meio do (Termo de Consentimento Livre Esclarecido -TCLE). 
As miçangas variam desde o tamanho ao formato, dependendo do desenho. Muitos vão para outras aldeias procurando grafismos diferentes. Evy informou-me como obter o vermelho com tinta natural ${ }^{45}$, um tipo especial de madeira conforme ensinado por sua mãe Marii; um hábito de extração praticamente extinto tendo em vista a escassez do material e pouca agilidade no processo.

Os objetos fora dos padrões Mbyá ganham outra apropriação. Os grafismos quando vendidos, transmitem um aspecto encantado, ainda que afastados do uso original (CHAKRABARTY, 1992, 2010; BHABHA, 1994, 2013). Conta-se sobre os significados, que entre os Shipibo - Conibo, duas mulheres sentadas de lados opostos a um grande vaso, eram capazes de tecer o mesmo grafismo sem se verem ou acordar um desenho prévio (GEBHARDT-SAYER, 1986; CARNEIRO DA CUNHA, 2014).

De acordo com Appadurai ([1986] 2014, p. 42), “o desvio de mercadoria para rotas específicas é sempre um sinal de crise ou criatividade dependendo do contexto." Entre os Guarani as mercadorias expressam profundas percepções sobre o ritual e as negociações. Em um exemplo utilizado pela antropóloga Marilyn Strathern (2014), uma mulher turkana vende suas jóias em troca de comida em um campo de concentração; os hagens com dinheiros - conchas na Melanésia negociam braceletes por moedas francoinglesas. O sistema kula, oriundo da Melanésia, é um sistema regional extremamente complexo com circulação de objetos, normalmente entre homens de posses e estrangeiros no arquipélago do Massim, Costa Leste de Nova Guiné (STRATHERN, 1999, 2014).

Os mercados dos objetos sagrados, portanto, exibem um mercado de luxo que contém biografias específicas (APPADURAI, [1986] 2014; STRATHERN, 2014). Essas biografias circulam de um lugar para o outro à medida que os homens e mulheres trocam ou perdem valor em função das peças.

\section{A ESCOLA E O ATO DE PRODUZIR OBJETOS}

Elay afirma que a Arte Guarani aprendida na escola perde o sentido ainda que as legislações entendam a atividade como parte do currículo (BRASIL, 1998; BRASIL, 1999). A escolarização ocupa um lugar ambíguo, ora estratégico, ora como contraste a uma tradição anteriormente estabelecida (BASTOS LOPES, 2017; BENITES, 2012). Afirmar que a escolarização não é um "elemento novo entre índios", não é o suficiente tendo em vista que o externo - interno hibridizam-se em uma curiosa relação de violência, aproximação e negociação secular (BHABHA, 1994; DAS, 2011, 2015). 0 costume de produzir objetos como ressalta Roque, é uma função fundamentalmente feminina, embora mesma orientação não esteja associada exclusivamente ao gênero, mas a funções espirituais (MELIÀ, 2010, 2011).

Portanto, ao mesmo tempo que tornam - se explícita a natureza etnocêntrica de divisões analíticas como cultura-natureza, feminino-masculino, na qual se vêem visíveis as relações entre corporalidade, cosmologia e valor do conhecimento, como discutido pela Etnologia Perspectivista (VILAÇA, 2013; VIVEIROS DE CASTRO, 2012), a pouca análise sobre como o sagrado influencia a escolarização são desafios encontrados pelos Guarani. Os exemplos servem para interrogar generalizações principalmente quando analisamos políticas associadas a cosmologias (VIVEIROS DE CASTRO, 2012). É preciso assumir que as relações de troca com a escola não estão mediadas exclusivamente por condições externas, fixadas por uma relação com o entorno, nem simplesmente por fatores endógenos e incontaminados (BHABHA, 1994, 2013). 0 externo-interno hibridizam-se, nesse sentido, entre o que é um creditador Guarani (ete) e o que se refere às políticas dos "dos brancos" (juruá); termo fortemente empregado para se referirem à escola (BENITES, 2012; DA SILVA, 2015).

\section{CONSIDERAÇÕES - NOTAS CONCLUSIVAS}

Como argumentou Aracy Lopes (1995), é preciso analisar se as políticas curriculares estariam dispostas a abandonar as políticas de "modelo" 46 para pensar as distintas cosmologias e aprendizagens indígenas.

\footnotetext{
45 A árvore onde os Guarani extraem a tinta chama-se Catiguá. Primeiro raspam a madeira, em seguida, adicionam um pouco de cinzas ao caldeirão cheio de cascas, a cinza formada pela lenha sai vermelha com matizes de brasa. 0 padrão py'a tytya (formato de coração), além de ser utilizado para aproximar relações matrimoniais, o mesmo grafismo, é oferecido aos indivíduos com doenças cardíacas (DA SILVA, 2015).

46 Citarei o termo <brancos>, por ser assim o modo como os Guarani classificam os interlocutores não indígenas. Quando indaguei se haveria outra identificação para as demais culturas, foram enfáticos em afirmar que não, o termo que denomina o "não Mbyá" é representado como branco ou juruá (sinônimo de boca com cabelo, referente às características dos homens com barba). Ao referirem-se em português, utilizam frequentemente a expressão "os brancos", apesar da classificação "negro" ser denominada como kamba. Refere-se a modo de ser e morrer, cotidiano Guarani- Mbyá.
} 
Como constantemente afirmam, o "Português" e a "Matemática" aprendidos nas escolas, são preferencialmente os do "branco" para atender à relação com os não - mbyá. Assim, as trocas acontecem entre guaranis e estrangeiros, cujos membros não indígenas que passam pela escola são inseridos na relação do que pode ou não ser revelado e negociado com não indígenas.

Como explorei em outros artigos, a escola não funciona regularmente, o que é justificado pelo baixo orçamento e pelo desejo de terem "uma escola diferenciada e mais profundamente Guarani [sic]" (BASTOS LOPES, 2017; BENITES, 2012). Concordo, nesse sentido, com Camila Agostini (2011, p.179), quando afirma que "é preciso não apenas relativizar a noção de exotismo, mas encontrar os parâmetros para a tradução de uma realidade diversa, de natureza encantada, isto é, que tem a participação do sobrenatural como elemento constituinte da realidade." Existe uma correlação entre o divino e o sagrado e pensar nessas relações, portanto, nos afasta de modelos pré-concebidos para pensar a escolarização indígena.

\section{REFERÊNCIAS}

[1] Agostini, C. A vida social das coisas e o encantamento do mundo na Africa Central e na diáspora. MÉTIS: história \& cultura, Caxias do Sul, v. 10, n. 19, p. 165-185, 2011.

[2] Appadurai, A. The Social Life of Things: commodities in cultural perspective. New York: University Press, [1986] 2014.

[3] Bastos Lopes, D. A presença do invisível em escolas indígenas: escolarização, diferença e cosmologia entre os povos Mbyá (Guarani) do Rio de Janeiro. Cadernos Cimeac, Uberaba, v. 7. n. 2, p.1-17, 2017

[4] Benites, T. A escola na ótica dos Avá kaiowá: impactos e interpretações indígenas. Rio de Janeiro: Contracapa, 2012.

[5] Bessa Freire, J; Malheiros, M. Os aldeamentos indígenas do Rio de Janeiro. Rio de Janeiro: EdUerj/Mec/Fnde, 2009.

[6] Bhabha, H. K. The location of culture. London, New York: Routledge,1994.

[7] __ En la caverna de la acción. Nuevas ideas sobre el tercer espacio. In: BHABHA, H, K. Nuevas minorías, nuevos derechos: notas sobre cosmopolitismos vernáculos. Buenos Aires: Siglo Veintiuno Editores, 2013. p.79-88.

[8] Brasil. Referencial Curricular Nacional para as Escolas Indígenas. Ministério da Educação. Brasília: Mec, 1998. Disponível em: <http://portal.mec.gov.br/cne/>.

[9] Brasil. Diretrizes Curriculares Nacionais da Educação Escolar Indígena. Ministério da Educação, Brasília: MEC, 1999. Disponível em: <http://portal.mec.gov.br/cne/>.

[10] Campos, M. C. A arte do corpo Mbyá - Guarani: processos de negociação, patrimonialização e circulação de memória. Tese de Doutorado (Memória Social). Universidade Federal do Estado do Rio de Janeiro, 2012.

[11] Carneiro da Cunha, M. Políticas culturais e povos indígenas: uma introdução. In: Carneiro Da Cunha, M.; Cesarino, P. de N. Políticas Culturais e Povos Indígenas. São Paulo: Cultura Acadêmica, 2014.

[12] Chakrabarty, D. Postcoloniality and the Artifice of History: Who Speaks for "Indian" Pasts? Representations. Special Issue: imperial fantasies and postcolonial histories, New York, v. 1, n. 37, p. 100 -122, 1992.

[13] Chakrabarty, D. From civilization to globalization: the 'West' as a shifting signifier in Indian modernity'. Journal Inter-Asia Cultural Studies, v. 13, n. 1, p. 138-152, 2012

[14] Das, V. 0 ato de testemunhar: violência, gênero e subjetividade. Cadernos Pagu, São Paulo, v. 37, p. 9-41, 2011.

[15] Das, V. Affliction: health, disease, poverty. Nova Iorque: Fordham University Press, 2015.

[16] Da Silva, A. (Mbyá). O grafismo e significados do artesanato da comunidade guarani da linha gengibre: desenhos na cestaria. Trabalho de Conclusão do Curso de Licenciatura Indígena Intercultural do Sul da Mata Atlântica (Educação). Universidade Federal de Santa Catarina -UFSC, Florianópolis, 2015.

[17] Fundação Nacional de Saúde (Funasa). Disponível em: <http://www.funasa.gov.br/internet/index.asp>. Acesso em: 04 de março de 2014.

[18] Gebhardt-Sayer, A. Una terapia estética. Los disenos visionários del ayahuasca entre los Shipibo - Conibo. América Indígena, XLVI, 1986.

[19] Ladeira, M. I. O caminhar sob a luz: o território Mbyá à beira do oceano. São Paulo: Unesp, 2007.

[20] Litaiff, A. Les fils du soleil: mythes et pratiques des indiens Mbyá-Guarani du littoral du Brésil. Thése (Ph.D) Anthropologie. Université de Montréal. Montréal, Canadá, 1999. 
[21] Lopes da Silva, Aracy; Grupioni, Luís D. B. A Temática Indígena na Escola. Novos subsídios para professores de 1o e 2ºgraus. Brasília: MEC / /USP / Unesco, 1995.

[22] Melià, B. Passado, presente y futuro de la lengua guaraní. Asunción: Ceaduc/ISEHF, 2010.

[23] Melià, B. Mundo Guaraní. Asunción: Banco Interamericano de Desarrollo, 2011.

[24] Schaden, E. (Org.). Aspectos fundamentais da cultura Guarani. São Paulo: Difusão Europeia do Livro, 1954.

[25] Silva, A. Mboapy Nhanderuvixa Tenondé Guá'i Oexara'ú Va'é Kuery Tekoa Sapukai Py Guá: kaxo yma guare, nhe'ẽ ngatu, nhembojera [Três sonhadores do Tekoa Sapukai: história, oralidade, saberes]. Trabalho de Conclusão de Curso (Licenciatura em Educação do Campo), Universidade Federal Rural do Rio de Janeiro, Seropédica, 2013.

[26] Souza Lima, A.C. O exercício da tutela sobre os povos indígenas: considerações para o entendimento das políticas indigenistas no Brasil contemporâneo. Revista de Antropologia (USP. Impresso), São Paulo, v. 55, n.2, p. 781832, 2012.

[27] Strathern, M. Property Substance and Effect: anthropological essays on persons and things. London: Athlone Press, 1999.

[28] Strathern, M. O efeito etnográfico. São Paulo: Cosac Naify, 2014.

[29] Unesco (Organização das Nações Unidas Para a Educação Ciência e Cultura). Boletim de la infancia y adolescencia sobre el avance de los objetivos del desarrollo del milenio, Santiago. Desafíos, n. 32, p. 1-32, 2017.

[30] Vilaça, A. M. N. Two or threee things that I know about talking to the invisible. HAU: Journal of Ethnographic Theory, Chicago, v. 3, n.3 p. 359-363, 2013.

[31] Viveiros de Castro, E. Cosmological perspectivism in Amazonia and elsewhere. Hau - Journal of Ethnographic Theory (Masterclass Series), Chicago, v. 1, p. 45-168, 2012. 


\section{Capítulo 24}

Protagonismo nas produções textuais de alunos quissamaenses: Um desafio para todos os envolvidos na educação

\section{Edwilson da Silva Andrade}

\section{Martha Caroline Duarte de Brito Freitas}

Resumo: Ser atuante no seu próprio processo de aprendizagem, ganhando papel de destaque (e não de coadjuvante), é um desafio enriquecedor para o aluno do século vigente e uma proposta que há alguns anos já vem ganhando espaço no contexto educacional, mas que precisa de fato ser implementada, de modo que os discentes sintam-se realmente autores de suas próprias histórias, em todos os âmbitos. Partindo desse pressuposto, esse trabalho apresenta uma prática pedagógica bem-sucedida que colocou alunos de uma escola municipal de Quissamã em posição de protagonistas do seu processo educativo: com o objetivo de desenvolver as habilidades de leitura e de escrita, discentes dos $3^{\circ}$ e $5^{\circ}$ anos do Ensino Fundamental produziram textos e ilustrações, que se tornaram livros e posteriormente, foram apresentados numa Noite de Autógrafos. Nesse contexto, o referido artigo busca evidenciar que é possível transformar atividades corriqueiras no cotidiano escolar, como o momento da produção textual, em espaços de desenvolvimento do protagonismo, demonstrando a necessidade e a importância da reflexão a respeito da temática.

Palavras-Chave: Produção Textual, Protagonismo, Autoria, Educação.

Parte deste trabalho foi apresentado no Congresso Nacional de Práticas Inclusivas: Mediações e Apresentações (CONAPI), na Universidade Estadual do Norte Fluminense (UENF), em Campos dos Goytacazes, 2019. 


\section{PONTO DE PARTIDA}

Como professores da educação básica da rede pública de ensino, conhecemos e compartilhamos de uma realidade que não é unicamente das escolas na qual atuamos: as dificuldades na leitura, interpretação e produção textual. Esse é um fato que permanece penosamente nas séries iniciais. Mas, também nas séries finais do Ensino Fundamental. Entretanto, acreditamos que no cotidiano das escolas produzem-se diferentes saberes que nos dão pistas de que é possível oferecer diferentes oportunidades de aprendizagem aos alunos com mais dificuldade. Principalmente, quando o acompanhamento é sistemático e constante. Ele torna-se um indicativo que permite planejar atividades para aprimorar a qualidade da educação. Esse é um desafio para todos os envolvidos com/na Educação.

Esse tem sido o desafio da equipe gestora da Escola Municipal Professora Tânia Regina Paula, situada no município de Quissamã, no Estado do Rio de Janeiro, a qual atende crianças do primeiro segmento (1ํo ao 5ㅜ ano de escolaridade). E desde de 2017, a gestão atual da unidade escolar vêm trabalhando para garantir os direitos de aprendizagem em todos os anos de escolarização ofertado na instituição. Como resultado desse trabalho, a escola obteve média 6,2 no Ideb, sendo esse o maior índice de toda a história obtido pela escola, desde a sua criação.

"Se a qualidade de ensino é aluno aprendendo, é preciso que ele saiba disso: é preciso "combinar" com ele, envolvê-lo como protagonista de qualquer mudança educacional." (GADOTTI, 2007, p. 13). Por acreditarmos nesse pensamento, e por saber que "A escola não é só um espaço físico. É acima de tudo, um modo de ser, de ver. Ela se define pelas relações sociais que desenvolve. E, se quiser sobreviver como instituição, precisa buscar o que é específico dela."(GADOTTI, 2007, p.12). Desta forma, não apenas como escola, mas, como rede de ensino temos convidado nossas crianças a lerem, produzirem e refletirem sobre textos que circulam em diferentes esferas sociais. Sabemos que cada escola é única, fruto de sua história, trajetória, de sua localidade, de seus projetos e de seus agentes. Deste modo, a experiência aqui relatada é fruto de um projeto desenvolvido pela escola mencionada anteriormente, a qual após uma avaliação diagnóstica em todos os anos de escolaridade, se deparou com algumas questões mais urgentes, como: incentivar a leitura fluente daqueles que já liam, consolidar a escrita de outros alunos por meio de trabalho com textos, principalmente, no $3^{\circ}$ e 5ㅇa ano de escolaridade.

Foi pesquisando sobre o projeto da Estante Mágica e pensando a nossa realidade enquanto escola, é que a gestão escolar viu o projeto como uma ferramenta de incentivo à leitura e à escrita. Já que para estimular esse protagonismo por meio da escrita e leitura, a Estante Mágica oferece às escolas um projeto gratuito que torna cada criança autora do próprio livro, com direito a evento de autógrafos e tudo. Apesar de a atividade ser comum em unidades privadas, a escola abraçou o projeto e no ano de 2018 fechou parceria com a Estante Mágica, a qual culminou na noite de autógrafos "Pequenos Escritores" realizada na própria escola com a presença dos pequenos autores, seus responsáveis, equipe escolar, autoridades locais e de colaboradores do projeto.

\subsection{PROTAGONISMO COMO ESTRATÉGIA PEDAGÓGICA}

A temática não é nova na educação. Entretanto, com a implementação da Base Nacional Comum Curricular - BNCC, o tema tem sido recorrente nas pesquisas e tendências educacionais. Muitas pessoas e grupos buscam compreender o sentido desse termo para adequar, ou, até mesmo explicitar outras possibilidades de fomentar a participação dos estudantes no processo de ensino-aprendizagem. Embora seja uma questão frequente na área da educação, não existem muitas literaturas que trabalhem com este conceito e nem com uma metodologia de formação para preparar protagonistas. Por isso, quando nos referimos ao protagonismo, neste artigo estamos nos referindo a crianças de 8 a 12 anos de idade, como personagens principais de uma ação voltada para a solução de problemas reais, ou seja, a participação ativa e construtiva do (a) estudante, envolvendo-o em situações que o incentive a leitura fluente e consolide a escrita por meio de trabalho com textos.

De acordo com Scheineder (2015, p.10), "por Protagonismo Infantil entende-se a percepção da criança como alguém potente, capaz de criar formas de se comunicar e de se relacionar com o mundo desde o início da vida e, por isso, capaz de participar com autonomia de seus próprios processos de ensino e de aprendizagem".

Isso nos leva a concluir que, o protagonismo está relacionado com a construção de conhecimento, que é um processo individual e que depende tanto das condições do sujeito como das condições do meio a qual está inserido. Deste modo, a aprendizagem deve ser entendida como um processo dinâmico, no qual a 
participação ativa do indivíduo é fundamental. Daí a importância de estratégias de trabalho que valorizem a autonomia.

Sobre o protagonismo do estudante, a socióloga Helena Singer relata que:

O estudante é o centro de um processo que deverá levá-lo ao desenvolvimento em suas diversas dimensões - intelectual, afetiva, corporal, social, ética. Tal processo tem como ponto de partida e de chegada a autonomia. 0 sujeito tornase autônomo quando é capaz de pesquisar e aprender sobre qualquer assunto que lhe interessa, quando se relaciona consigo mesmo e com os próximos de maneira saudável e respeitosa, adota hábitos de autocuidado e vive de forma coerente com seus princípios e valores. (2017, p. 17)

Esta participação propositiva, proativa, só se desenvolve se a criança se apropriar do conhecimento por meio de interações, ampliando a aprendizagem, o desenvolvimento e a socialização. Neste sentido, o professor tem o papel de refletir, selecionar e organizar um conjunto de práticas e interações que sejam significativas para os estudantes. Sendo assim, "O êxito do ensino não depende tanto do conhecimento do professor, mas da sua capacidade de criar espaços de aprendizagem, vale dizer, "fazer aprender" e de seu projeto de vida de continuar aprendendo." (GADOTTI, 2003, p. 41).

Assim, o professor torna-se também um protagonista, o qual é responsável por proporcionar um ambiente propício à aprendizagem, como orientador, organizador, e motivador dos seus aprendizes. Conclui-se, então, que o professor tem um papel diferente do que normalmente se pensa. Requerendo do mesmo uma compreensão clara do significado social e político do seu trabalho.

Este é um desafio que envolve todos os envolvidos na Educação: Aprenderensinar. Principalmente, porque diante do dinamismo e da modernidade trazidos pelas novas tecnologias, é comum que os estudantes busquem informações mais rápidas e acessíveis, o que pode levar muitos deles a pensar que ler é perda de tempo. Diante disso, a escola e seus agentes devem prosseguir empreendendo em suas práticas pedagógicas, ações que demonstrem que a leitura e a produção textual continuam sendo uma importante ferramenta para melhorar o desempenho escolar.

Logo, elaborar estratégias pedagógicas que preparem os estudantes para agir com autonomia, solidariedade e responsabilidade; interagindo, participando, cooperando, convivendo com as diferenças; aprendendo e processando os conhecimentos, usando-os para o bem comum; utilizando-os para beneficiar-se das oportunidades oferecidas pela educação ao longo de toda a vida torna-se um desafio, porque "A escola precisa estar atenta às mudanças profundas que o contexto midiático contemporâneo está provocando na cabeça de crianças e jovens". (GADOTTI, 2003, p. 50-51). Isso requer também que a escola e seus agentes trabalhem o desenvolvimento de competências e habilidades.

Por isso, a educação do século 21 prever uma formação em que os estudantes sejam protagonistas, autor da própria história, considerando cada indivíduo, suas culturas, respeitando o modo de vida das pessoas e sua identidade. Este é o conceito básico de educação que nos fala a UNESCO, por meio do relatório Jacques Delors (1998), na qual nos revela a educação em quatro pilares básicos: Educar para ser, conviver, conhecer e fazer. Portanto, podemos sintetizar que o papel da escola é aprenderensinar com a finalidade de transformar a realidade social. Entretanto, observamos que estes fundamentos estão distantes do cotidiano pedagógico escolar, porém devemos tê-los como meta para uma educação baseada no desenvolvimento humano.

Portanto, a experiência aqui relatada teve como público-alvo cerca de 183 estudantes, com idade entre 8 e 12 anos, matriculados respectivamente no $3^{\text {o }}$ e $5^{-}$ano de escolaridade, vale ressaltar que deste quantitativo, 5 alunos são público da educação inclusiva. Ao se pensar no protagonismo e na perspectiva da educação inclusiva, percebemos que o projeto seria uma oportunidade de ampliar e potencializar as possibilidades de ensino desse grupo.

Para que os 5 alunos e os demais também ampliassem e potencializassem suas possibilidades de aprendizagem/de escrita, foi preciso que cada professor refletisse sobre sua prática e pensasse em um currículo que fosse capaz de atender as peculiaridades de todos discentes. Para isso, a escola, teve que romper com a perspectiva homogeneizadora e precisou adotar estratégias que assegurassem a participação de todos. A iniciativa para a realização deste projeto sob título "Pequenos Escritores", partiu da gestão da Escola que apresentou a sugestão à equipe pedagógica e aos docentes, os quais demonstraram-se engajados desde o primeiro momento. Tomando o projeto como uma prática pedagógica inovadora e uma fonte rica de possibilidade no que se refere ao incentivo a leitura e a 
produção textual, colocando literalmente a criança como protagonista de uma história e de um projeto que incentiva o seu desenvolvimento e que está em consonância com a proposta da BNCC.

Nesse contexto, é preciso considerar, que a autoria é um dos elementos fundamentais do protagonismo. Principalmente, se levarmos em consideração que a autoria começa com pequenas produções realizadas no cotidiano escolar, como atividades educativas. Assim, desenhos, cartazes, poemas, poesias e outras produções, ganham notoriedade se forem valorizadas pela escola e seus agentes. Uma vez que, os estudantes ao sentiram que suas criações estão sendo reconhecidas, buscam comprometer-se mais na sua aprendizagem, desenvolvendo diversas capacidades importantes, como criatividade, colaboração, participação, além de os aproximarem ainda mais da escola.

\section{PEQUENOS ESCRITORES}

No projeto Pequenos Escritores, desenvolvido na Escola Municipal Professora Tânia Regina Paula, o protagonismo foi trabalhado a partir do envolvimento dos alunos no projeto, na qual eles foram oportunizados a desenvolverem um produto, um livro. Esse trabalho exigiu do estudante uma série de capacidades relacionadas ao uso do Sistema de Escrita Alfabética, bem como outras competências relacionadas ao processo de produção como planejamento e revisão da própria escrita. Nesse sentido, o trabalho didático com o projeto tinha sobretudo a intenção de consolidar os direitos de aprendizagem, proporcionando situações em que a linguagem oral e escrita, leitura e produção de texto se interrelacionassem de forma contextualizada, promovendo a autoria, autonomia, responsabilidade e a solidariedade.

Sobre essa relação entre linguagem oral/escrita e leitura/produção textual (assim como da heterogeneidade da língua), Vacario e Silva, ao mencionarem a obra "Produção textual, análise de gêneros e produção" (Marcuschi, 2008), advogam que:

Ao se discutir a produção de texto, seja na modalidade oral ou escrita, faz-se necessário esclarecer ao leitor a noção de língua inicialmente adotada, e desde as primeiras linhas ele reitera a noção de língua sob a perspectiva sociointerativa, ao esclarecer que a língua é um conjunto de práticas sociais e cognitivas historicamente situadas de forma que o interlocutor não tenha dúvidas de que a língua não é um sistema abstrato, mas é heterogênea, social, histórica, cognitiva, indeterminada, variável, interativa e situada. (VACARIO e SILVA, 2017, p. 263)

Nesse contexto, ao longo do desenvolvimento do projeto Pequenos Escritores ficou evidente que a língua é reflexo de uma cultura, de vivências sociais e históricas. As produções textuais dos alunos, sem dúvida, carregam esse sentimento vivo da língua e, consequentemente, seus registros passaram a ganhar sentido, e não algo abstrato sem nenhuma ligação com o contexto dos mesmos.

Figura 3: Fragmento do Livro de um dos participantes do projeto "Pequenos Escritores"

Eu sou o querido

Moro no Goiabal com meus pais. Gosto muito do lugar onde moro e sou feliz nele.
Figura 4: Ilustração do livro de um dos participantes do projeto

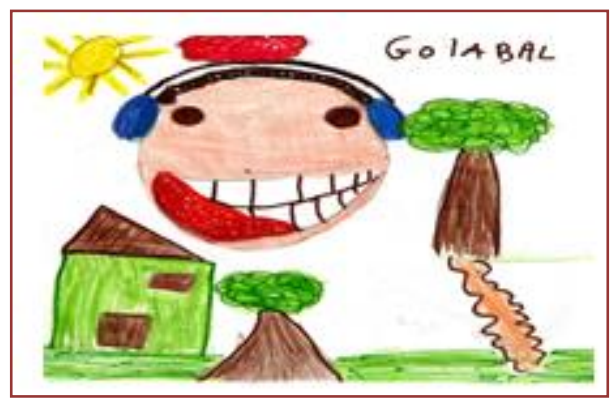

O projeto foi planejado para um tempo estimado de um bimestre. 0 tema do projeto foi escolhido pelos próprios alunos, a partir das opções apresentadas pelos professores. Sendo assim, cada turma foi oportunizada a escolher o tema que trabalhariam. Os temas escolhidos foram "Contos de fada modernos", "Família", "Amizade" e "Autobiografia". Desta maneira, foi possível perceber que quando os estudantes têm a oportunidade de escolher entre duas ou mais opções, não apenas encontram alternativas 
interessantes, mas igualmente sentem-se mais valorizados e envolvidos no desenvolvimento do projeto, além de terem a oportunidade de conhecer, experimentar e enveredar por diversos gêneros textuais relacionados à tipologia narrativa.

De acordo com Segate (2010, p.23),

o ensino com gêneros textuais é de fundamental importância no processo de ensino-aprendizado da língua. Afinal, o trabalho em sala de aula com os diversos gêneros contribui para o aluno ter acesso à língua em funcionamento, o que permite ao aprendiz maiores condições para receber e produzir diversos textos.

Durante as aulas, cada estudante recebeu o seu material, o qual consistiu numa folha para elaboração do texto mais as folhas para ilustração da capa e das 6 páginas que compõem o livro. Todo material foi desenvolvido pela Estante Mágica, o qual constava os dados da escola, do aluno e um código de identificação. Cada professor teve liberdade para desenvolver o projeto a partir da proposta disponibilizada na plataforma da Estante Mágica aos professores.

Sendo assim, através dos projetos temáticos elaborados pela Estante Mágica como uma ferramenta para auxiliar o professor durante o desenvolvimento do trabalho, os mesmos puderam ter clareza que uma das características centrais do projeto é a participação dos estudantes como forma de terem mais autonomia em suas aprendizagens. Por isto, o projeto Pequenos Escritores desenvolvido na instituição possibilitou uma série de atividades, tendo como objetivos principais:

- $\quad$ Compreender a funcionalidade da escrita;

- $\quad$ Ampliar e enriquecer o vocabulário;

- Produzir trabalhos de arte utilizando a linguagem do desenho e da pintura.

Portanto, foram propostas situações didáticas por meio das quais os estudantes sentiram a necessidade de ler e produzir textos diversos, tais como biografias, contos, diários, entre outros. Essa iniciativa despertou nos estudantes o interesse pela leitura e aflorou a imaginação como possibilidade criadora de recontar uma história, ou melhor, a sua história e/ou até mesmo a sua leitura de mundo, o que vai ao encontro do que Paulo Freire revela: "a compreensão crítica do ato de escrever não se esgota na decodificação pura da palavra escrita, mas se antecipa da inteligência do mundo" (2001, p.11).

É claro que muitos desafios surgiram ao longo do projeto. Um deles foi a recusa das crianças matriculadas no $3^{\circ}$ ano que ainda não haviam chegado no estágio alfabético. Todavia, os professores engajados na proposta, organizaram outras atividades para que esses estudantes pudessem produzir outro tipo de texto. Desse modo, durante os momentos de produção textual, os professores precisaram adotar estratégias para assegurar que todos os estudantes participassem. Tornando-se necessário um trabalho mais efetivo, voltado para os direitos de aprendizagem relacionados ao sistema de escrita.

Ao selecionar e adotar estratégias, de forma que todos discentes sejam participativos e atuantes, o professor possibilita ao estudante:

compreender e construir o conhecimento de maneira autônoma, responsável e atuante devido a diversidade de procedimentos utilizados, atendendo as especificidades dos alunos. Para tanto o papel do professor é significativo e crucial a fim de que os educandos possam engajar-se na própria aprendizagem como sujeitos automotivados; à medida que verbaliza aos sujeitos suas crenças, valores, estrutura as atividades e o ambiente pedagógico de maneira dinâmica, possibilitando a participação de todos enriquecendo as aulas com experiências (MOREIRA, 2015, p. 506)

Dentre os desafios, talvez o maior deles, foi de oportunizar as crianças públicos da educação inclusiva, a ter acesso, plena participação e igualdade de oportunidade como as demais crianças. Assim, a equipe pedagógica em parceria com as professoras, que tiveram que adotar estratégias que eliminassem as barreiras existentes. Principalmente, porque cada criança possui uma condição diferenciada. Portanto, em alguns casos permitiu-se que as crianças inclusas escrevessem espontaneamente. Nessa situação, os professores tomavam a leitura dos mesmos, para que pudessem reescrever o texto como escriba do autor. Em outras situações, não foi possível os próprios estudantes escreverem. Assim, as professoras aproveitaram alguns materiais disponíveis nos portfólios dos discentes para transformarem em livro, por meio de fotografias e do reconto de sua rotina escolar. 
Diante do exposto, podemos afirmar que a inclusão vai muito além de inserir alguém num espaço físico. Incluir demanda sensibilidade, respeito e entendimento, como Mantoan defende: "Inclusão é a nossa capacidade de entender e receber o outro e, assim, ter o privilégio de conviver e compartilhar com pessoas diferentes de nós. A educação inclusiva acolhe todas as pessoas, sem exceção" $(2005$, p.96).

Por concordarmos com a autora, queremos destacar a expressão "sem exceção", ressaltando que tal projeto foi desenvolvido em parceria com a Estante Mágica e o patrocínio para impressão dos livros partiu dos responsáveis pelos alunos bem como também de toda equipe escolar, visto que uma parte dos educandos não poderia arcar com os custos. Consequentemente, a escola precisou promover condições para que todos os pudessem participar deste projeto e ao final cada um pudesse ter pelos menos um exemplar do livro para assim realizarmos a grande noite de autógrafos.

Contudo, a escola que é de natureza pública de esfera municipal, buscou de todas as formas, soluções para que nenhum aluno ficasse sem o livro, levantando recursos através de rifas e campanhas para que os alunos fossem apadrinhados, a fim de promover condições para aqueles que não possuíam situação financeira em adquirir pelos menos um exemplar, assegurando assim, plena participação e possibilidade de aquisição da obra. Pois, entendemos que a inclusão é aquela que legitima as mesmas oportunidades para todos e que também é capaz, a partir de um olhar reflexivo e atencioso, de atender às especificidades de cada um. Independente, de se o estudante é público da educação inclusiva ou não.

Essa atitude de toda comunidade engajada em prol da participação efetiva de todos alunos dos anos contemplados também pode ser considerada uma prática inclusiva, visto que ao se pensar em inclusão nesse projeto foi considerado o que tal posicionamento frente ao diferente é de fato, conforme Dellani e Moraes advogam: "Inclusão engloba uma educação para todos, centrada no respeito e valorização das diferenças. Uma posição que reforça a necessidade do respeito à diferença, o conhecimento e o preparo para lidar com as potencialidades e limitações das pessoas" (2012, p.4).

Todavia, as estratégias adotadas dependeram das especificidades de cada aluno, da experiência e da criatividade, independente do discente ser público da educação inclusiva ou não, promovendo assim uma "educação para todos" (SASSAKI, 1997), ou melhor, um momento que todos puderam ser sujeitos ativos do conhecimento, por meio do resgate da autonomia e do desenvolvimento da criatividade.

O desenvolvimento do projeto na unidade escolar ocorreu simultaneamente com o desafio anual que a Secretaria de Educação do Município, através da Coordenação de Gestão Pedagógica (COGEP), propõem as equipes gestoras das unidades escolares, e que naquele ano, o desafio era a produção textual semanal, com o intuito de oportunizar o trabalho com diferentes gêneros textuais em sala de aula, possibilitando aos estudantes, um conhecimento de mundo mais amplo e favorável à sua construção de conhecimentos.

Nesse sentido, este trabalho torna-se relevante não apenas por enveredar pelo universo da inclusão, mas também por estimular e encantar os diversos alunos participantes através de uma prática escolar que proporcionou a aprendizagem, de forma lúdica e prazerosa, promovendo o incentivo à leitura e à escrita dos discentes, a partir do protagonismo dos mesmos nas produções textuais.

\section{CONSIDERAÇÕES FINAIS}

Refletir sobre o protagonismo a partir da experiência com o Projeto Pequenos Escritores provoca a percepção de que a melhor maneira de incentivar a educação é colocando luz em experiências inovadoras.

É de suma importância redimensionar os papéis de todos os sujeitos envolvidos no processo educativo: professores, além de outros direcionamentos, devem atuar como mediadores e o conhecimento apresentado/orientado será a ponte para que o aluno brilhe como protagonista em direção às suas conquistas, vivências e experiências.

Assim, o projeto Pequenos Escritores aponta uma possibilidade, dentre tantas outras, de configurar a atuação e o posicionamento do aluno frente às demandas escolares. Num país em que, conforme dados de pesquisas revelam, o índice de deficiência em leitura e escrita é preocupante, é urgente que aconteçam e se desenvolvam ações que possam sanar determinadas carências e lançar um olhar mais atencioso sobre o trabalho com as habilidades linguísticas, o qual poderá repercutir positivamente nas produções escritas dos nossos alunos, por meio de um texto coeso, coerente, segmentado, pontuado corretamente, atrativo e que também demonstre o protagonismo do aluno. Esse é o grande desafio. 
Nesse sentido, torna-se cada vez mais oportuno divulgar as práticas do cotidiano escolar, sobretudo, sobre as práticas dos sujeitos na escola como forma de validar o espaço da educação. Pois, a escola produz e consome diferentes saberes, sendo eles científicos ou não.

\section{REFERÊNCIAS}

[1] Corrêa, Maria Helena Calazans. A inclusão de alunos com necessidades educacionais especiais no ensino regular. 2010. 28f. Artigo apresentado no Curso de Especialização em Educação Especial (Especialização em Educação Especial). Universidade Federal de Santa Maria.

[2] Dellani, Marcos Paulo; MORAES, Deisy Nara Machado. Inclusão: caminhos, encontros e descobertas. Revista de Educação do Ideau: vol.7, no 15, jan-junho 2012.

[3] Delors, Jacques (Org). Educação: um tesouro a descobrir. Relatório para a UNESCO da Comissão Internacional sobre Educação para o século XXI. São Paulo: Cortez, 1998.

[4] Freire, Paulo. A importância do ato de ler. São Paulo: Cortez, 2001.

[5] Gadotti, Moacir. A boniteza de um sonho: ensinar e aprender com sentido. Novo Hamburgo: Feevale, 2003.

[6] Gadotti, Moacir. A escola e o professor: Paulo Freire e a paixão de ensinar. São Paulo: Publisher Brasil, 2007.

[7] Mantoan, Maria Teresa Eglér. Inclusão escolar: pontos e contrapontos. Rosangela Gavioli Prieto: Valeria Amorim Arantes (Org.). 5. Ed. São Paulo: Summus, 2006.

[8] Marcuschi, Luiz Antonio. Produção textual, análise de gêneros e compreensão. São Paulo: Parábola Editorial, 2008. 298p.

[9] Moreira, Ana Elisa da Costa. O papel docente na seleção das estratégias de ensino. In: XVI Semana da Educação e VI Simpósio de Pesquisa e Pós-graduacão em Educação do Departamento de Educação, 2015, Londrina (PR). ISBN: 978-85-7846-319-9, p 497 - 508

[10] Sassaki, Romeu Kazumi. Inclusão: construindo uma sociedade para todos. Rio de Janeiro: WVA, 1997

[11] Schneider, Mariângela Costa. O protagonismo infantil e as estratégias de ensino que o favorecem em uma turma de educação infantil. Dissertação de Mestrado. Centro Universitário Univates. Lajeado, 2015.

[12] Segate, Aline. Gêneros Textuais no Ensino de Língua Portuguesa. Linha D’Água, (23), 2010, p. 13-24. https://doi.org/10.11606/issn.2236-4242.v0i23p13-24

[13] inger, Helena. (2017) Pelo protagonismo de estudantes, educadores e escolas. In: Lovato, Antonio; Yirula, Carolina; Franzim, Raquel (orgs.) Protagonismo: a potência de ação da comunidade escolar. São Paulo: Ashoka/Alana, 2017

[14] Vacario, Marcia; Silva, Albina. Processos de produção textual e compreensão na perspectiva sociointerativa. Rev. Educ., Cult. Soc., Sinop/MT/Brasil, v. 7, n. 1, p. 262-268, jan./jun. 2017 


\section{Capítulo 25}

\section{A educação física como instrumento de inclusão escolar}

\section{Diego Soares Souza}

Julianna Mendes de Matos Souza

Silvana Carolina Fürstenau dos Santos

Wylker Souza Saraiva

\section{Glaydson de Oliveira Soares}

Resumo: A Educação Física como processo inclusivo favorece a construção de valores e atitudes fundamentados na cooperação e solidariedade, possibilitando aos alunos com necessidades educacionais especiais desenvolverem suas competências, ultrapassando os limites de sua situação. Diante disso, o estudo tem como objetivos principais verificar como a educação física cumpre sua especificidade ao possibilitar aos alunos com deficiência ampliarem suas potencialidades e, analisar, o conhecimento e a formação dos professores de educação física que atuam em escolas inclusivas. 0 procedimento metodológico utilizado nessa pesquisa foi o método qualitativo, uma vez este contribui para a sistematização e interpretação das informações construídas, neste sentido o estudo teve por base, observações e entrevistas semiestruturadas com os professores das turmas inclusivas. Com isso, a pesquisa permitiu concluir que, a educação física adaptada permite que todos vivenciem diferentes práticas corporais advindas das mais diferentes manifestações.

Palavras-chave: Educação física. Inclusão escolar. Alunos com deficiência.

*I Seminário Nacional de Educação Inclusiva e Acessibilidade, 2018, Goiás 


\section{INTRODUÇÃO}

Os alunos com algum tipo de deficiência, ao longo dos anos, começam a assumir seu papel na sociedade, muitos começam a criar raízes de identidade e autoestima, mas dependendo da sua limitação, muitos desses alunos precisam de uma educação toda especial e adaptada.

Pensando na Educação Física, em que, mesmo não tendo alguma deficiência, muitos alunos não conseguem participar das aulas, por vários motivos, falta de espaço, falta de material, falta de habilidade motora do aluno, falta de interesse dos alunos. (DARIDO e RANGEL, 2011). No caso dos alunos com deficiência é muito mais complexo participar dessas aulas, sendo assim é importante refletir sobre a Educação Física como instrumento de inclusão escolar.

Atualmente, o tema inclusão está sendo ampliado, principalmente nas escolas em geral. Porém, pouco se tem estudado sobre o processo de inclusão na prática da Educação Física escolar. Pouco se sabe como os alunos com necessidades educacionais especiais estão participando das atividades de Educação Física e, como os professores dessa modalidade estão lidando com essa nova realidade nas escolas. Desse modo, o objetivo principal da pesquisa é saber como a Educação Física pode ser um instrumento de inclusão escolar.

Como objetivos específicos procurou-se verificar como a Educação Física cumpre sua especificidade ao possibilitar aos alunos com deficiência a ampliação das suas potencialidades e, também, analisar o conhecimento e a formação dos professores de educação física que trabalham em escolas inclusivas. Diante disso, a pesquisa pode contribuir, no sentido de proporcionar respostas aos professores de Educação Física sobre a realidade da inclusão, e ampliar as formulações teóricas a esse respeito.

\section{FUNDAMENTAÇÃO TEÓRICA}

0 processo da inclusão educacional de alunos com necessidades educacionais especiais e de outros alunos com quem a escola tem dificuldade de lidar, tem muito a beneficiar com as propostas metodológicas dos professores de Educação Física que, com criatividade, podem usar o corpo, o movimento, o jogo, a expressão e o desporto como oportunidades de celebrar a diferença e proporcionar aos alunos experiências que realcem a cooperação e a solidariedade (RODRIGUES, 2003).

Para Carvalho (1998) e Oliveira e Poker (2002), a educação inclusiva pressupõe uma educação apropriada e de qualidade para todos os alunos. Sendo assim, a prática do ensino inclusivo tem como objetivo a inclusão de todos independente de seu talento, deficiência (sensorial, física ou cognitiva), origem socioeconômica, étnica ou cultural.

Sobre a educação inclusiva, Peter Mittler (2003), define a inclusão como um processo de reforma nas escolas, esse conceito de inclusão envolve um repensar radical da política e da prática e reflete um jeito de pensar fundamentalmente diferente sobre as origens da aprendizagem e as dificuldades de comportamento. (p. 25).

Com isso, o ambiente escolar tem que ser organizado e acolhedor, para que se transforme em um verdadeiro espaço inclusivo, rico e diversificado, já que a educação inclusiva tem como foco principal a escolarização de todos os alunos nos próprios espaços escolares.

Conforme Mantoan, (2006) é inegável o poder das ideias inclusivas para virar as escolas do avesso, das propostas para que as escolas se transformem e se abram-se às diferenças e assim possam ensinar aqueles que não estão se beneficiando com a escolarização e que estão sendo excluídos da escola. Nesse sentido a Educação Especial, vem valorizar as diversas formas de aprender.

A Educação Especial no período atual é marcada pelo movimento da inclusão que ocorre em âmbito mundial e refere-se a uma nova maneira de ver a criança, de excludente da diferença para a de contemplar a diversidade. (MIRANDA, 2008)

A Educação Especial, vem valorizar as diversas formas de aprender. No Brasil, as pessoas com deficiência tiveram seus direitos assegurados, primeiramente na Constituição Federal de 1988, em alguns artigos, tais como:

Art. 203 - A assistência social será prestada a quem dela necessitar, independentemente de contribuição à seguridade social, e tem por objetivos: 
IV - a habilitação e reabilitação das pessoas portadoras de deficiência e a promoção

de sua integração à vida
comunitária;

Art. 208 - 0 dever do Estado com a educação será efetivado mediante a garantia de:

III - atendimento educacional especializado aos portadores de deficiência, preferencialmente na rede regular de ensino;

Art. 227 - É dever da família, da sociedade e do Estado assegurar à criança e ao adolescente, com absoluta prioridade, o direito à vida, à saúde, à alimentação, à educação, ao lazer, à profissionalização, à cultura, à dignidade, ao respeito, à liberdade e à convivência familiar e comunitária, além de colocá-los a salvo de toda forma de negligência, discriminação, exploração, violência, crueldade e opressão.

A Lei № 9394/96 (Lei de Diretrizes e Bases da Educação Nacional/1996), aborda a Educação Especial afirmando que, os sistemas de ensino devem assegurar aos alunos, recursos, currículo, métodos e organização específicos para atender as necessidades dos alunos com deficiência.

Essa mesma Lei, traz em alguns artigos as seguintes normas com relação à Educação Especial:

Art. 58 . Entende-se por educação especial, para os efeitos desta Lei, a modalidade

de educação escolar, oferecida preferencialmente na rede regular de ensino, para educandos portadores de necessidades especiais.

Parágrafo único. 0 poder Público adotará, como alternativa preferencial, a ampliação do atendimento aos educandos com necessidades especiais na própria

rede pública regular de ensino, independentemente do apoio às instituições previstas neste artigo.

No parágrafo único, infere-se que, sendo o atendimento dos alunos com deficiência realizado na rede regular de ensino, a lei já traz uma grande abertura para a inclusão, já que esses alunos estarão em contato direto com alunos que não tem necessidades educacionais especiais.

A educação inclusiva como processo primordial para a formação educacional da pessoa com deficiência tem como objetivo favorecer uma educação voltada ao respeito às diferenças. Sabe-se que a Educação Especial possibilita o alcance de condições favoráveis à sua efetiva participação social (DISTRITO FEDERAL, 2010).

Nesse sentido, a Educação Física escolar, também sofre influência do processo inclusivo, e com isso, segundo Aguiar (2005), deve ter como eixo fundamental o aluno o qual precisa desenvolver as competências e condições para que todos tenham acesso aos conteúdos que propõe, com participação plena, adotando estratégias adequadas para evitar a exclu são ou alienação dos alunos (AGUIAR, 2005).

Para Betti (1999) e Darido (2001), os princípios da Educação Física devem considerar os alunos com deficiência presentes no ambiente escolar assumindo estratégias e ações que apoiem, estimulem, incentivem, valorizem e promovem o processo de inclusão dos alunos com deficiência nas atividades práticas das aulas de Educação Física.

Os Parâmetros Curriculares Nacionais para o Ensino Médio (BRASIL, 1999) referem- se ao conhecimento da Educação Física, apontando o esporte de cunho educativo como eixo norteador a ser trabalhado na escola e a prática deve atender a todos os alunos, respeitando suas diferenças e estimulando-os ao maior conhecimento de si e de suas potencialidades. Os Parâmetros, realçam ainda, o significado do trabalho em grupo, valorizando a interação aluno-aluno e professor-aluno como fonte de desenvolvimento social, pessoal e intelectual. Desta forma, deve-se considerar as diferenças individuais e de respeito aos outros, num exercício de ética e cidadania.

A Educação Física integra o currículo escolar, Darido e Rangel (2011), salientam que nem sempre fazer 
parte do currículo quer dizer que essa disciplina consiga oferecer igualdade de oportunidades a todos. Mas, as mesmas autoras entendem que se todos têm direitos de participar das aulas de Educação Física, o professor deve encontrar alterativas para a não exclusão.

De acordo com Mittler (2003), tanto os docentes como os coordenadores e os gestores escolares podem atuar como facilitadores, assegurando aos estudantes acesso ao currículo e a experiências favoráveis de aprendizagem, desenvolvimento e participação.

Então, para que a escola inclusiva cumpra o seu papel em respeitar e garantir o direito dos alunos com necessidades educacionais especiais, de terem acesso a uma educação de qualidade, é preciso que o professor de Educação Física esteja bem preparado. Nos Referenciais para a Formação do Professor (MEC 1999, 18-19), são definidos os seguintes pressupostos: "o professor exerce uma atividade profissional de natureza pública que tem dimensão coletiva e pessoal, implicando simultaneamente autonomia e responsabilidade". Sendo assim, é preciso que em seu desempenho profissional, os professores mostrem dedicação, carinho e profissionalismo.

Darido e Rangel (2011), afirmam também, que um professor que não acredita que seu aluno possa aprender acaba por convencê-lo disso. Para elas, mesmo que não se manifeste explicitamente, suas formas de agir, suas expressões, seu tom de voz entre outras coisas, podem conter mensagens que dizem muito aos alunos.

A Educação Física adaptada é essencial, já que o aluno com deficiência precisa aprender a desenvolver suas habilidades e capacidades motoras. É preciso que a escola que se quer inclusiva ofereça vivências de forma que a educação formal faça sentido para o aluno com necessidades educacionais especiais.

\section{METODOLOGIA}

A pesquisa se caracterizou como qualitativa. A abordagem qualitativa permite, explorar os dinamismos internos das situações com a tentativa de compreender a "perspectiva dos participantes", ou seja, a forma como os participantes da pesquisa encara as questões

investigadas (LUDKE; ANDRÉ, 1986, p. 12).

0 processo de construção de dados passou pelas seguintes fases: o estudo foi realizado na cidade satélite de Sobradinho - Distrito Federal, em escolas públicas e particulares, totalizando seis escolas, em que foram pesquisadas três escolas públicas e, outras três escolas particulares, todas escolas, consideradas inclusivas, já que atendem alunos com deficiência.

A pesquisa foi realizada com a participação de doze professores que atuam nos Ensinos Fundamental e Médio. 0 perfil destes docentes pode ser caracterizado por uma maioria do sexo masculino. Em termos de faixa etária, a maior parte está na faixa dos trinta anos, os outros estão na faixa dos quarenta e, apenas um, tem cinquenta anos de idade. Em relação à pergunta do questionário sobre a existência de alguma disciplina direcionada para a área da Educação Física adaptada em sua formação, destes, quatro não tiveram nenhuma disciplina específica e, não são formados em Educação Física, todos os outros são formados em Educação Física e tiveram disciplinas sobre Educação Especial.

A partir daí, foi analisado o preparo dos professores nas aulas de Educação Física adaptada e, feitas observações da participação dos alunos com deficiência física nas aulas de Educação Física. A pesquisa teve o intuito de analisar alunos com diversos tipos de deficiências, porém nas escolas pesquisadas só estudavam alunos com deficiência física, por isso o estudo ficou limitado a esse público. Foram seis alunos observados, no total.

Foi aplicado um questionário, em que o professor formado ou não em Educação Física, respondeu se realmente há um preparo do profissional para ministrar aulas adaptadas para pessoas com deficiência e, também, foram analisados, por meio de fichas de observação, as aulas de Educação Física em que os alunos com deficiência física participaram.

0 questionário aplicado foi um formulário de entrevistas semiestruturado, onde houve a análise de dados qualitativos e de questões básicas que consistiu nos dados quantitativos. Para análise das aulas foi usado um roteiro de observação participante, em que foi descrito o espaço, os materiais utilizados nas aulas, a atuação do profissional, a ação dos participantes e a relação do professor de Educação Física com os alunos com deficiência. 


\section{RESULTADOS}

Com relação às entrevistas realizadas com os professores e concordando com as ideias de Mauerberg-de Castro e Palla (2004), pode-se concluir que, tanto a carência de conteúdos de Educação Física adaptada na formação acadêmica dos docentes que atuam no ensino fundamental e médio, quanto a falta de experiência de trabalho com alunos com alguma deficiência traz a exigência e urgência de se desenvolver planos de ação incluindo a criação de cursos de capacitação profissional na Educação Física adaptada para os professores que atualmente estão na escola ou em outros setores da educação. 0 aumento da carga horária nas disciplinas de Educação Física com ênfase na Educação Especial, e a implantação de estágios supervisionados obrigatórios em Educação Física adaptada, se fazem necessários.

Ao analisar a questão sobre quais os conteúdos que facilitam ou dificultam as aulas de Educação Física, a maioria dos entrevistados, afirmaram que tanto os esportes coletivos quanto as atividades recreativas são facilitadores da participação e da inclusão das pessoas com alguma deficiência. Para Darido e Rangel (2011), o professor pode ter efetivamente uma prática inclusiva nos jogos, quando apoia, estimula, incentiva, valoriza, promove e acolhe o estudante.

A alternativa "esportes individuais" não foi assinalada por nenhum dos participantes da pesquisa, como sendo promotor da inclusão. Assim, como na pesquisa segundo Darido e Rangel (2011), no ambiente escolar, os esportes individuais têm encontrado pouco espaço, o que, de certa forma, representa uma limitação à aprendizagem dos alunos, pois eles auxiliam, dentre outras coisas a descoberta do próprio corpo inclusive suas limitações. Sendo assim, os esportes não coletivos também têm sua importância, porém não são tão valorizados, principalmente em um ambiente inclusivo.

Com relação às atividades recreativas, em alguns argumentos destaca-se a reflexão de que nessas atividades há mais integração e, os próprios alunos, podem ajudar seus colegas a se integrarem e entenderem as tarefas propostas, essencialmente aqueles alunos com limitações físicas. Contudo, há reflexões que embora admitam este potencial nas atividades recreativas, esta fica em desvantagem nas turmas de alunos mais velhos os quais preferem os esportes coletivos, com mais regras e técnicas que por sua vez, infelizmente, excluem mais as pessoas com deficiência.

Para tanto, acrescentam Cidade e Freitas (1997), é importante que o professor tenha os conhecimentos básicos relativos ao seu aluno como: tipo de deficiência, idade em que apresentou a deficiência, se foi repentina ou gradativa, se foi transitória ou permanente, as funções e estruturas que estão prejudicadas. Implica, também, que esse educador conheça os diferentes aspectos do desenvolvimento humano: biológico (físico, sensoriais, neurológicos); cognitivo; motor; interação social e afetiva emocional.

Concordando com os autores, Dias da Silva (apud DARIDO e RANGEL, 2011, p. 104), escreve algumas dicas para auxiliar o profissional de Educação Física, segundo ele, três aspectos são importantíssimos: o domínio do conteúdo e metodologia, o envolvimento e a apropriação da realidade dos alunos e o caráter reflexivo do trabalho docente. É preciso que a escola inclusiva ofereça aos professores espaços de reflexão e atitudes únicas, de forma que a educação motora faça sentido para os alunos com deficiência.

Sobre as observações, o principal objetivo foi saber como o aluno com deficiência era incluído nas aulas práticas de Educação Física. Conforme Ferreira (2006), o trabalho de Educação Física deve possibilitar aos alunos terem, desde cedo a oportunidade de desenvolver habilidades corporais e de participar de atividades culturais, com finalidade de lazer, expressão de sentimentos, afetos e emoções. Mas, muitas vezes, a falta de materiais adaptados para trabalhar com os alunos com deficiência e a falta de acessibilidade foram grandes barreiras para o desenvolvimento de um trabalho de qualidade, assim o trabalho do professor ficava abaixo do esperado.

Na maioria das escolas, os alunos com deficiência física, a maioria cadeirante, realizava jogos de tabuleiro, enquanto os outros alunos praticavam algum esporte. Em uma escola, observou-se a inclusão do aluno no início das aulas de Educação Física, na hora do alongamento, depois ele ia conversar com os colegas de turma ou ler algum livro. Quando o trabalho é realizado da maneira correta, por um professor consciente da sua prática, pode contribuir para o processo de socialização e integração escolar. 0 que não foi observado em algumas escolas.

Já em outra, foi realizado um projeto com os alunos, trazendo o basquete com cadeira de rodas, para que a aluna pudesse participar da atividade, foi um momento muito rico e divertido. Os alunos puderam se sentir incluídos no universo da aluna e ela na rotina de atividade deles. Ferreira (2006), infere que na prática, é importante que o aluno percebe a Educação Física como um instrumento facilitador da aprendizagem, entendendo os conteúdos propostos e estabelecendo relações nas suas diversas dimensões. É importante que o aluno com deficiência seja integrado nas aulas de 
Educação Física, para que assim ele se sinta parte importante da sociedade.

\section{CONSIDERAÇÕES FINAIS}

Com isso, conclui-se que, a Educação Física adaptada permite que todos vivenciem diferentes práticas corporais advindas das mais diferentes manifestações. Assim, a inclusão na escola regular é um processo pelo qual esta, se adapta e se transforma, para poder inserir em suas classes do ensino regular e nas diferentes modalidades, como a Educação Física, alunos com alguma deficiência. Contudo, para que a verdadeira inclusão aconteça e atenda às reais necessidades dos alunos é preciso garantir a formação dos professores e professoras que atuam na área, seja por meio de sua capacitação básica, seja em cursos e programas desenvolvidos pelas escolas que vivenciam situações de inclusão, ou por meio da própria vontade do profissional em buscar bibliografias para auxiliar no seu trabalho.

É importante também, que o profissional de Educação Física trabalhe a interdisciplinaridade na escola inclusiva, buscando o apoio dos demais profissionais da escola para o desenvolvimento de atividades cooperativas, em que todos participem efetivamente das atividades propostas. Outro aspecto que pode ser trabalhado, é a inserção de outras atividades no currículo e, não só aquelas esportivas que necessitam de habilidades motoras especificas.

A partir da pesquisa pode-se refletir, que ainda falta muito para a efetiva inclusão dos alunos com deficiência nas aulas de Educação Física, muitas escolas e a maioria dos profissionais não se sentem preparados para incluir atividades adaptadas na grade curricular, pois falta desde políticas públicas que efetivem a verdadeira inclusão, até espaços adaptados e bem conservados, há ainda a carência de materiais esportivos, além do pouco conhecimento de alguns profissionais, e a insegurança dos professores em trabalhar com a inclusão. Mas, de acordo com a Orientação Pedagógica do Distrito Federal (2010), não é apenas a qualificação profissional do professor, inicial e continuada, fator indicativo de sua competência para atuar com estudantes com necessidades especiais. É imprescindível que ele disponha de qualidades humanas e de desenvolvimento profissional que o capacite para essa atuação.

Por fim, a partir da pesquisa é possível aprender sobre a autonomia da elaboração de atividades adaptadas, a flexibilidade dos planejamentos, a capacidade de discutir metodologias de forma coletiva, modificar regras e estabelecer uma melhor utilização dos conhecimentos adquiridos nas aulas de Educação Física adaptada aos alunos com deficiência, com vistas a uma inclusão efetiva. Com a pesquisa foi possível, também aprender mais sobre o curso de Educação Física e, sobre a forma como é, e como pode ser realizado um trabalho de qualidade, com os alunos com necessidades educacionais especiais.

\section{REFERÊNCIAS}

[1] AGUIAR, João Serapião De; DUARTE, Édison. Educação Inclusiva: um estudo na área da Educação Física. Revista Brasileira de Educação Especial. Ed. Esp., Marília, Mai.-Ago. 2005, v.11, n.2, p.223-240.

[2] BETTI, M. Educação Física, esporte e Cidadania. Revista Brasileira de Ciências do Esporte. n. 20, pp. 84 92, 1999.

[3] BRASIL, Constituição (1988). Constituição da República Federativa do Brasil: promulgada em 5 de outubro de 1988.

[4] BRASIL. Lei de Diretrizes e Bases da Educação Nacional. Brasília, Câmara dos Deputados, 1996.

[5] BRASIL. Parâmetros curriculares nacionais - ensino médio - educação física. Brasília: Secretaria de Educação Fundamental, 1999.

[6] DISTRITO FEDERAL, Educação Especial: Orientação Pedagógica. Brasília, Secretaria de Estado e Educação do Distrito Federal, 2010.

[7] CARVALHO, R. E. Temas em Educação Especial. Rio de Janeiro: WVA, 1998.

[8] CIDADE, Ruth Eugênia, FREITAS, Patrícia Silvestre. Noções sobre Educação Física e Esporte para Pessoas Portadoras de deficiência. Universidade Federal de Uberlândia, Uberlândia-MG, 1997.

[9] DARIDO, Suraya Cristina: RANGEL, Irene Conceição Andrade. Educação Física na Escola: Implicações para a Prática Pedagógica. Guanabara Koogan, 2011.

[10] FERREIRA, Vanja. Educação Física: Interdisciplinaridade, aprendizagem e inclusão. Rio de Janeiro: Sprint, 2006. 
[11] LÜDKE, Menga e ANDRÉ, Marli E. D. A. Pesquisa em educação: abordagens qualitativas. São Paulo: EPU, 1986.

[12] MANTOAN, M.T.E. Ser ou estar, eis a questão: explicando o déficit intelectual. Rio de Janeiro: WVA. (2000).

[13] MAUERBERG-DE-CASTRO, Eliane, PALLA, Ana Cláudia. Atitudes de Professores e Estudantes de Educação Física em Relação ao Ensino de Alunos com Deficiência em Ambientes Inclusivos. Universidade Estadual Paulista, University of Virginia. Revista da Sobama. Dezembro 2004, volume 9, número 1, p: 25 - 34, São Paulo.

[14] MIRANDA, A.A.B. Educação Especial no Brasil: desenvolvimento histórico. Cadernos de História da Educação - n. 7 - jan./dez. 2008.

[15] MITTLER, Peter. Educação Inclusiva: Contextos Sociais. Editora: Artmed, São Paulo, 2003.

[16] RODRIGUES, David. A Educação Física perante a Educação Inclusiva: reflexões conceptuais e metodológicas. Universidade Técnica de Lisboa Faculdade de Motricidade Humana - Departamento de Educação Especial e Reabilitação. Boletim da Sociedade Portuguesa de Educação Física. 24/25, p. p: 73 - 8, Lisboa, 2003.

[17] OLIVEIRA, A. A. S.; POKER, R. B. Educação inclusiva e municipalização: a experiência em educação especial de Paraguaçu Paulista. Revista Brasileira de Educação Especial. Marília, v. 8, n. 2, p. 233-244, 2002. 


\section{Capítulo 26}

\section{Inclusão social e incentivo no processo de aprendizagem no brejo paraibano através das olimpíadas científicas}

\section{Márcia Verônica Costa Miranda \\ Williams Alves Xavier}

Resumo: 0 incentivo no processo de ensino-aprendizagem pode ser determinante para que um aluno tenha sucesso em qualquer disciplina, série ou ano escolar, independentemente de idade ou de classe social. As Olimpíadas Científicas são consideradas instrumento de auxílio nas diversas áreas, seja na Matemática, Informática ou Ciências em geral. São utilizadas com o intuito de estimular um crescimento na fixação dos conteúdos em sala de aula pelos alunos e promover sua autoconfiança e autoestima, sendo consideradas como ferramentas de aprendizagem e inclusão social. 0 objetivo do presente trabalho é apresentar as ações executadas no projeto "Olímpiada Paraibana de Informática-Sede Areia-PB", no auxílio e desenvolvimento dos alunos do Ensino Fundamental do município de Areia - PB, das zonas urbanas e rural. Em 2018, foi realizada a sexta edição da Olimpíada Paraibana de Informática (OPI), cujo objetivo, foi despertar nos alunos o interesse por jogos de raciocínio lógico, promovendo o desenvolvimento das habilidades individuais e em grupo dos participantes, facilitando o aprendizado interdisciplinar. 0 projeto é de grande importância, pois promove a inserção social de alunos carentes, visto que suas ações provocaram uma diminuição na evasão escolar, melhoria no desempenho escolar dos alunos e uma motivação aos estudantes carentes que vivem em estado de vulnerabilidade social. Os alunos areenses, nas últimas edições da OPI, têm ocupado lugares de destaque na competição em nível Estadual, colaborando com a inclusão social e aprendizado dos alunos das escolas públicas e privadas que residem na zona rural e urbana.

Palavras-chave: Olimpíadas Científicas, Educação, Informática, Inclusão social. 


\section{INTRODUÇÃO}

$\mathrm{O}$ incentivo no processo de ensino-aprendizagem pode ser determinante para que um aluno tenha sucesso em qualquer disciplina, série ou ano escolar, independentemente de idade ou de classe social. Os fatores que têm impacto no desempenho escolar dos alunos são, entre outros, a motivação pessoal, a combinação adequada de orientação do professor e interesse próprio, a jornada escolar e atividades extracurriculares motivadoras ao processo de aprendizagem.

Essas constatações oferecem elementos para o desenvolvimento de ações e atividades que possibilitem a melhoria da aprendizagem e a busca de inovações no campo educacional. No Brasil, observa-se ser necessária a utilização de artifícios que estimulem os alunos a terem uma melhor compreensão e fixação do conteúdo ministrado em sala de aula. (KLEIN, 2007) Neste aspecto, podem ser realizadas diversas atividades extracurriculares que auxiliem o aluno fora da rotina escolar, afastando-os do ócio e das ruas.

As competições escolares são atividades que podem impulsionar o desenvolvimento da autoconfiança e autoestima dos estudantes, como também suas habilidades de trabalhar em equipe (MONTEIRO et al., 2013) Atualmente, as olimpíadas científicas vêm tomando destaque no meio acadêmico, sendo utilizada por diversas áreas de conhecimento como ferramenta de aprendizado e inclusão. Mais do que medalhas, prêmios e diplomas de participação, as olimpíadas científicas brasileiras proporcionam a estudantes e professores novas descobertas, novos lugares, ideias, técnicas e conhecimentos. Anualmente é possível participar de diferentes olimpíadas científicas, regionais, estaduais ou nacionais. As olimpíadas, de forma geral, têm estimulado muitos jovens a descobrir mais sobre as ciências e as tecnologias, bem como tem possibilitado introduzir a motivação para a pesquisa, a procura e estudo extracurricular. Além disso, algumas competições procuram estabelecer um intercâmbio entre escolas e instituições de ensino superior, que também pode ser um estímulo para a escolha profissional do estudante.

Segundo Bzuneck e Guimarães (2004), a intenção das práticas que resultam na comparação entre os aprendizes é motivar os estudantes, influenciando que estes se dediquem mais aos estudos, participem das atividades escolares e usem estratégias mais eficazes para aprender. De acordo com Robinson (2003), coordenador das olimpíadas científicas do Ensino Médio de Nova Iorque, tais competições desafiam os estudantes, com problemas de raciocínio lógico e ciências, incentivando a criatividade e diversificando as formas de aprendizagem.

Hoje, é senso comum que a Informática é indispensável no que se diz respeito à informação e a comunicação dentro e fora do contexto educativo, a qual estimulou muitas mudanças no processo de aprendizagem. Atualmente, as crianças já nascem mergulhadas no mundo tecnológico, e, por esse motivo, a Informática vem sendo muito utilizada como ferramenta educacional, buscando fazer interações entre o dia-a-dia dos estudantes e o conteúdo visto em sala de aula, estimulando uma escola voltada para a realidade. Desta feita, a computação cada vez mais tem se sedimentado como um importante recurso pedagógico, e não apenas uma tecnologia a mais, pois é preciso direcionar conhecimentos e mecanismos que a integre à educação (MALFATTI et al., 2004).

Dentro do contexto de utilizar as ferramentas da Informática como recurso educacional e motivador na educação e no desenvolvimento local, o Projeto de extensão universitária "Olímpiada Paraibana de Informática - Sede Areia - PB", vem sendo desenvolvido desde 2013, no Centro de Ciências Agrárias (CCA) da Universidade Federal da Paraíba (UFPB). 0 projeto abrange desafios motivadores, troca de ideias e utilização dos conhecimentos e situações do cotidiano das crianças do brejo paraibano em contexto às aulas e atividades. Além disso, visou o despertamento pela busca da autoconfiança dos alunos em andamento a inclusão social, no sentido de mudar a vida das pessoas que foram atendidas por este projeto, em especial às escolas da zona rural, onde em muitas das vezes não eram inseridas igualitariamente em projetos extracurriculares similares a escolas urbanas. Vale destacar que, nos últimos 2 anos, o projeto tem direcionado suas atividades para atender crianças e adolescentes das escolas públicas de Areia-PB, cidade do brejo paraibano, tanto da zona urbana quanto da zona rural, no sentido de incluir social e educacionalmente camada vulnerável da sociedade, que ainda não possuem recursos educacionais equânime em comparação às escolas privadas.

Diante do conteúdo exposto, o objetivo do presente trabalho é descrever as atividades realizadas na $6^{\underline{a}}$ edição do projeto "Olimpíada Paraibana de Informática - Sede Areia", que busca despertar nos alunos da rede pública e privada de ensino fundamental de Areia-PB o interesse pelos jogos de lógica, matemática e computação, promovendo a inclusão social e competição saudável entre os participantes, tirando-os do ócio, das ruas e de ações infrutíferas, e provendo uma perspectiva incentivadora de dar continuidade em seus estudos. 


\section{METODOLOGIA}

Sob coordenação da equipe de informática do CCA-UFPB, desde 2013 o projeto Olimpíada Paraibana de Informática (OPI) - Sede Areia vem sendo executado anualmente no município de Areia-PB com crianças dos Ensinos Fundamentais I e II, consistindo nos níveis 1 e 2 desta competição.

As provas da Olimpíada Paraibana de Informática estão estruturada em três níveis:

- Iniciação I e II (1o ao 8o ano do Ensino Fundamental),

- Programação (9o ano do Ensino Fundamental ao Ensino Médio) e

- Avançado júnior (Ensino Superior).

A OPI-Areia optou por concentrar suas atividades nos níveis Iniciação I e II, para atender melhor as crianças e adolescentes mais necessitados, que carecem de uma assistência melhor no ensino, notadamente os alunos das escolas públicas, tanto da zona urbana quanto rural.

Em sua 1a edição, as escolas do município obtiveram $75 \%$ das medalhas destinadas a alunos de escolas públicas de todo o Estado da Paraíba. Em 2017 o desempenho dos alunos treinados pela equipe foi considerado excelente, destacando-se na segunda categoria de Iniciação em Escolas Públicas, onde 100\% das medalhas e premiações estaduais foram conquistadas por alunos da OPI Sede Areia.

Além da Olimpíada Paraibana de Informática (OPI), desde 2015 também é executada nos níveis 1 e 2 na cidade a Olimpíada Brasileira de Informática (OBI), que possui a mesma estrutura de níveis e séries escolares da OPI. Ambas as competições são fundamentadas em questões envolvendo assuntos de raciocínio lógico e analítico, nas quais são apresentadas situações-problemas que envolvam o cotidiano dos alunos.

Para melhor encaminhamentos dos trabalhos, foi planejado as atividades nas escolas do Município, identificando, através de visitas locais e reuniões com professores e diretores das escolas, os pontos de maior carência que deveriam ser abordados pela equipe. Inicialmente, foi realizada uma reunião com a comissão organizadora da OPI Sede Areia, onde foi estabelecido um cronograma (Tabela 1) para realização das atividades do projeto. Em contato com a Secretaria de Educação do Município de Areia-PB, foi firmada uma parceria, em que tal órgão deu o suporte necessário para realização das inscrições dos alunos da zona rural e urbana de toda cidade, com participação de alunos do Ensino Fundamental de escolas públicas e privadas.

Com o intuito de melhorar o desempenho dos alunos em suas escolas e de motivá-los na aprendizagem, o treinamento da OPI buscou por executar atividades com abordagem de métodos de interpretação de texto, aulas de Ciências e de Matemática, que por sua vez contribuíram relevantemente para a melhoria em seus desempenhos escolares.

Tabela 1. Cronograma de Atividades.

Atividade Período

- Planejamento do projeto;

- Definição de atividades;

- Reuniões com a equipe local;

- Estabelecimento de parcerias.

- Divulgação do projeto;

- Inscrições de alunos;

- Planejamento e execução dos cursos preparatórios;

- Aplicação das provas em Fase única para escolas públicas e Fases 1 e 2 para escolas privadas.

- Correção das provas;

- Divulgação dos resultados;

- Solenidade de premiação e entrega de certificados;

- Avaliação geral da equipe do projeto.

Fevereiro a Março/2018

Março a Setembro/2018

Outubro a Novembro/2018

Nesta edição, o projeto iniciou com sete turmas e as aulas preparatórias foram ministradas por universitários voluntários dos cursos de graduação do CCA-UFPB. As aulas ocorreram nas escolas, que tinham alunos inscritos na OPI, tanto para zona urbana quanto para a zona rural. Esta decisão, tomada 
pela equipe do projeto, evitou uma maiores despesas de transporte por parte dos alunos carentes, foco do atendimento. A grande maioria dos alunos participantes da zona rural são filhos de agricultores que, assim como alunos da zona urbana, residem nas áreas mais carentes do município de Areia, em estado de grande vulnerabilidade social, evidenciando o aspecto inclusivo e social do projeto. No intuito de facilitar a locomoção destes alunos na realização das provas, foram providenciados meios de transporte, em acordo com a Secretaria de Educação Municipal, que por sua vez fizeram o deslocamento de mais de 200 alunos ao CCA-UFPB para os simulados e para a realização das provas da competição.

Os recursos didáticos utilizados nas aulas foram projetor multimídia, quadro branco, listas de exercícios e simulados práticos para facilitar a melhor compreensão e fixação do conteúdo pelos alunos, como também estimulá-los ao desenvolvimento de atividades extracurriculares. Todas aulas foram preparadas de acordo com o conteúdo das provas aplicadas em Olimpíadas nacionais da área, onde, com o auxílio dos instrutores, foram apresentados e resolvidos situações-problemas de raciocínio lógico e analítico, envolvendo o cotidiano dos alunos. Além disto, foram disponibilizadas listas de exercícios para os alunos responderem em casa e nas semanas antecedentes às provas, foram aplicados simulados para que os alunos se acostumassem com o modelo das provas Estadual e Nacional, com distribuição gratuita de todo material aplicado.

As provas da OPI tiveram uma duração de 2,5 horas, conforme exigências estabelecidas pelas organizações estaduais e nacionais. A aplicação das provas foi realizada por uma equipe de voluntários e pela professora coordenadora do projeto na Central de Aulas do CCA-UFPB para todos os alunos, tanto da zona urbana quanto da zona rural.

\section{RESULTADOS E DISCUSSÃO}

Até o momento, desde que a OPI foi introduzida no município de Areia-PB em 2013, cerca de 1.400 alunos já participaram do projeto no decorrer dos anos de sua execução, em que aproximadamente 210 destes alunos participaram da edição no ano de 2018, sendo $87 \%$ alunos oriundos de escolas públicas e $13 \%$ oriundos de escolas privadas, como ilustra o Gráfico 1.

Gráfico 1. Total de alunos inscritos na OPI 2018.

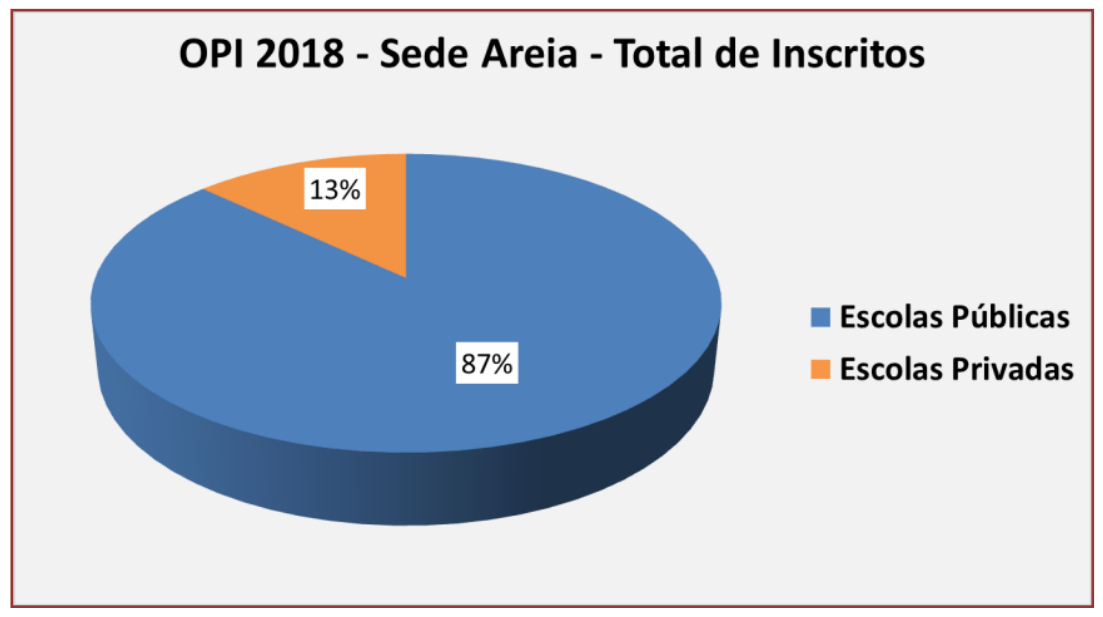

Em relação à premiação em nível Estadual, em 2013, com a aplicação da OPI, os alunos treinados no curso preparatório em Areia obtiveram 75\% das medalhas da competição Estadual na categoria Escolas Públicas. Nos anos 2014 a 2017, nesta mesma competição e também na categoria de Escolas Públicas, os alunos da OPI Sede Areia conquistaram 100\% das medalhas no nível Iniciação II. Tal fato é considerado grandioso, e reflete o trabalho de inserção social realizado pelo projeto com alunos carentes, destacando a utilização de conhecimentos interdisciplinares e aproveitamento por parte do público-alvo.

Pode-se observar, no Gráfico 2, o percentual de inscritos na OPI 2018 por nível, onde foram 67\% e 33\% inscritos nas Iniciação I e Iniciação II, respectivamente. A maior taxa de alunos inscritos na categoria Iniciação II se deu, principalmente, pelo fato de haver mais alunos matriculados no ensino Fundamental II nas escolas públicas de Areia-PB. 
Gráfico 2. Total de inscritos na OPI 2018 por modalidade de participação.

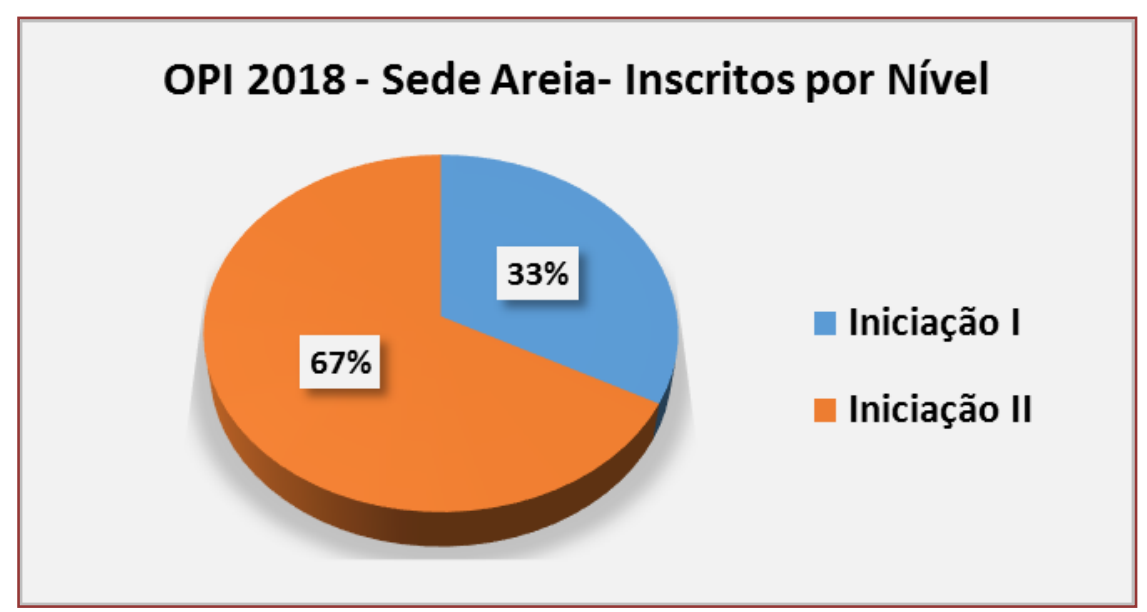

Após a aplicação das provas, nas instalações do CCA-UFPB, estas foram recolhidas pela equipe organizadora da OPI e encaminhadas para a Comissão Estadual da OPI, que se encontra na Sede da Universidade Federal de Campina Grande (UFCG), e foi realizada a correção das provas e divulgação dos resultados oficiais.

Após divulgação do resultado das provas, pode-se observar que o projeto em 2018 foi considerado de excelente aproveitament, visto que na Fase única de escolas públicas e Fase 1 de escolas privadas obtevese um ótimo rendimento e conquistas de premiações. De acordo com o Gráfico 3, podemos observar que, na categoria Iniciação I, os alunos treinados pelo projeto da Sede Areia obtiveram excelentes índices, 57\% de todas as medalhas e premiações destinadas à todas as cidades do Estado da Paraíba. Este fato evidencia os alunos areenses como destaque Estadual, engrandecendo a importância do treinamento para realização das provas da OPI.

Gráfico 3. Índice de alunos premiados na modalidade Iniciação I da OPI 2018.

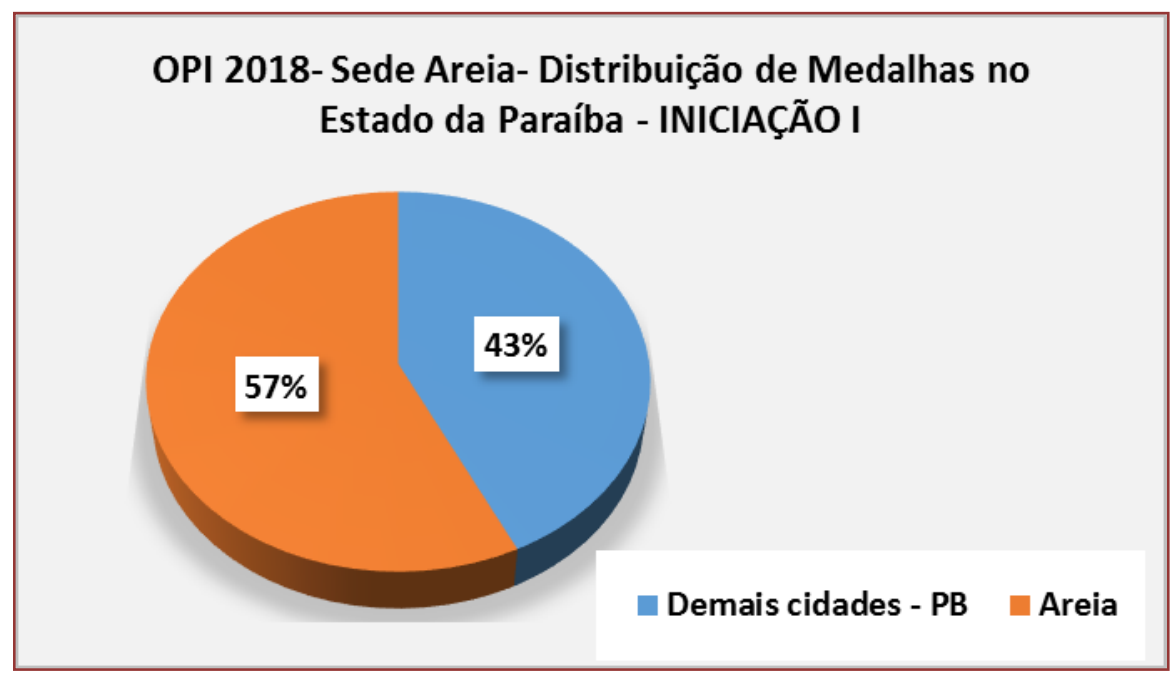

Na modalidade Iniciação II, os alunos da OPI Sede Areia também obtiveram um ótimo desempenho, visto que estes conquistaram 52\% das medalhas e premiações de todo o Estado da Paraíba, como ilustrado no Gráfico 4. 
Gráfico 4. Índice de alunos premiados na modalidade Iniciação II da OPI 2018.

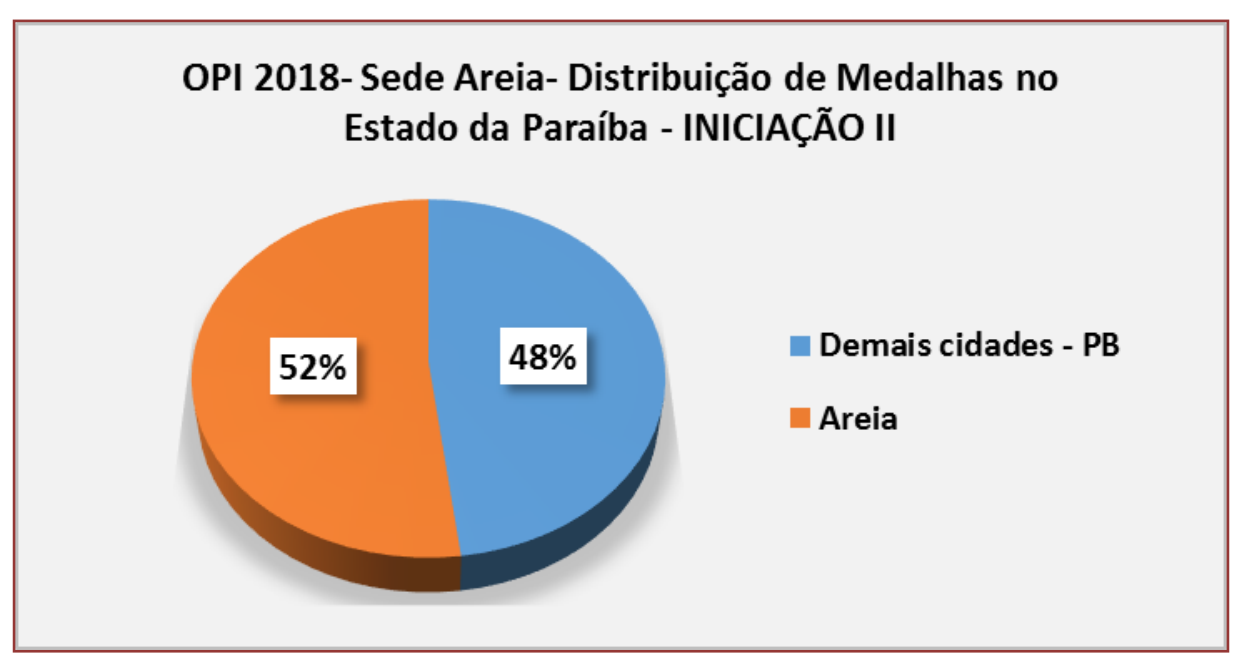

A participação dos alunos foi de fundamental importância para que viessem a obter êxito na competição, valorizando ainda mais as ações deste projeto. Na Figura 1, ilustra, na primeira foto, uma aula realizada na Escola Abel Barbosa, zona rural de Areia, que foi a escola que obteve o melhor desempenho dentre as escolas públicas do município.

Figura 1. Aulas preparatórias da Iniciação I e aplicação de provas da Iniciação II.

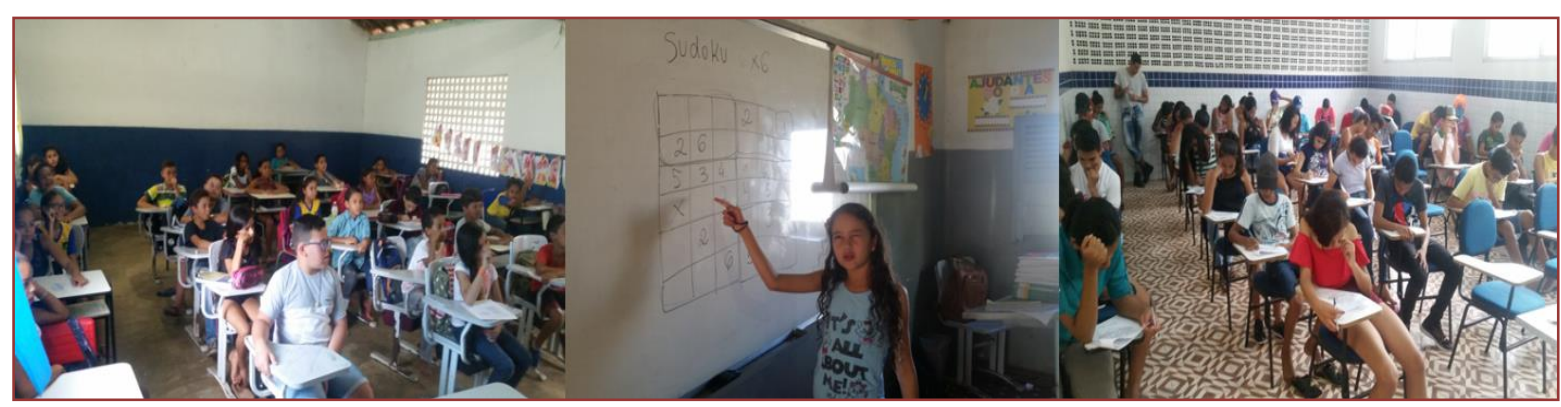

Através dos resultados expostos pode-se observar que o treinamento foi capaz de influenciar positivamente no desempenho dos alunos, tanto na prova da OPI, quanto em suas diversas atividades interdisciplinares em suas respectivas escolas, induzindo-os a praticar o raciocínio lógico de forma rápida e precisa.

Quando um aluno se prepara para a disputa de uma olimpíada, ele desenvolve o hábito da pesquisa, do estudo, da procura incessante pelo conhecimento, pela descoberta do novo. Enfim, desperta a vocação científica e passa a se sentir desafiado pelos concorrentes ou pelo próprio conhecimento, além de criar o hábito de trabalhar em equipe e de estudar objetivamente e com a parceria de um professor / tutor.

\section{CONCLUSÕES}

As atividades executadas pelo projeto de extensão universitária "Olimpíada Paraibana de Informática Sede Areia" contribuíram para a melhoria de desempenho escolar de alunos de escolas públicas e privadas do Município, solidificando-se como uma alternativa pedagógica e motivacional para que o aluno desperte o interesse em pesquisa, leitura, participação em sala de aula, bem como incluí-lo socialmente, provendo formas equânimes de estudos e compreensão de conteúdos que demandam raciocínio lógico, incluindo Ciências, Matemática, etc. Trabalhou-se com alunos carentes das zonas urbanas e rurais, possibilitando iguais oportunidades de participação para todos os alunos de escolas públicas e escolas privadas, que vivem em grande vulnerabilidade social. 
Os estudantes se sentiram motivados com o projeto e realmente participaram ativamente desta competição, demonstrando que os objetivos foram alcançados, ao estimular, nesses estudantes, o interesse e desejo pela busca de conhecimento na área da Computação e Ciências em Geral. A OPI conseguiu incentivar nos alunos a participação escolar, melhorar a qualidade do estudante que aprende e, assim como a vontade de continuar aprendendo, dependem diretamente da interação social entre os estudantes, dos objetivos que trazem à sala de aula e da motivação que deu origem a esses objetivos, onde este projeto contribui, como alternativa a essa motivação.

\section{REFERÊNCIAS}

[1] BZUNECK, J. A.; GUIMARÃES, S. E. R. Aprendizagem escolar em contextos competitivos. In: BORUCHOVITCH, E.; BZUNECK, J. A. (Org.). Aprendizagem: processos psicológicos e o contexto social na escola. Petrópolis: Vozes, p. 251$277,2004$.

[2] KLEIN, Ruben. Universalização do ensino básico. O Globo, p. 7-21, 2007.

[3] MALFATTI, S. M.; NUNES, M. A. N.; BRANCHER, J. D. \& ENGERS, E. M.; Aplicação de uma proposta pedagógica para a utilização do aplicativo Logo3D no processo de ensino aprendizagem da geometria. Simpósio Brasileiro de Informática em Educação - Sbie, Manaus-AM, 2004.

[4] MONTEIRO, L. A. et al. Olimpíada Paraibana de Informática Como ferramenta de contribuição na melhoria do aprendizado dos alunos de escolas públicas e privadas do município de areia, Areia PB, 2013.

[5] ROBINSON, S. Coaching a High School Science Olympiad Team. Academic Exchange, ed. Summer, p. 272-277, 2003. 


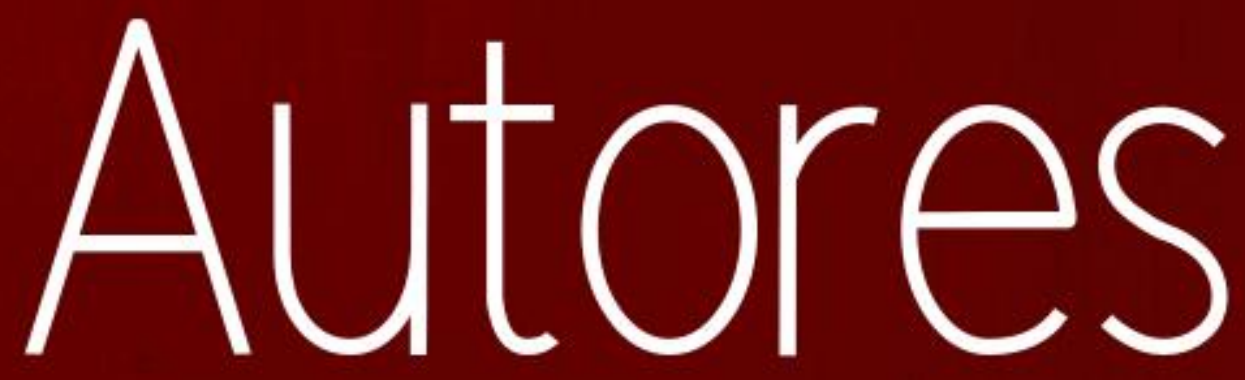




\section{ALINE ANTONIA SANTOS LINS}

Pedagoga. Psicopedagoga. Especialista em Atendimento Educacional Especializado. Cursando Especialização em Práticas Assertivas da Educação Profissional integradas à EJA. Técnica em Assuntos Educacionais no Instituto Federal de Ciência e Tecnologia do Maranhão-IFMA

\section{ALINE FROLLINI LUNARDELLI}

Professora do Departamento de Fundamentos da Educação da Universidade Estadual de Maringá UEM. Doutora em Psicologia Escolar e do Desenvolvimento Humano pela Universidade de São Paulo - USP- SP.

\section{ANA CARLA SEVERO ANDRADE}

Licenciada em Pedagogia pela Universidade do Estado da Bahia - UNEB (2016). Tem especialização em Libras - Educação de Surdos pela Universidade Norte do Paraná - UNOPAR (2017). Professora da UNILATUS e da Faculdade de Candeias - FAC e educadora dos anos finais do Ensino Fundamental. Desenvolve projetos de inclusão de surdos no Núcleo de Educação Especial de Itiúba - NEEI; Especialização em andamento em Letras/Libras - UNEB. Experiência na área de Linguística, com ênfase em Língua Brasileira de Sinais.

\section{ANMALY NATÁLIA MIGUEL MONTEIRO GILBERT}

Licenciada em Pedagogia pela Universidade Federal de Viçosa. Foi voluntária no projeto "Heart for Orphans", realizado com crianças carentes em duas instituições na Cidade do Cabo, África do Sul. Realizou Intercâmbio para a Universidade do Porto, Portugal, durante um semestre (seis meses), iniciado em setembro de 2014 e concluído em fevereiro de 2015. Foi bolsista do projeto "Percepção do ambiente degradado e propostas de intervenções a partir dos conhecimentos construídos pelos alunos assistidos pela APOV", onde atuou como professora. Realizou também estágios supervisionados em Educação Infantil, Ensino Fundamental, Educação especial e Gestão Escolar. Além disso, participou e organizou diferentes eventos durante o curso de Pedagogia. Exerceu o cargo de Coordenadora Pedagógica do Ensino Fundamental na Secretaria Municipal de Educação de Viçosa/MG. Está cursando o segundo ano do Mestrado em Educação pela Universidade Federal de Viçosa, onde atua na área de Metodologias Ativas.

\section{APARECIDA RAMAZOTTI DE CAMARGO}

Mestre em Geografia pela UEL. Especialista em Pedagogia para o Ensino Religioso pela PUCPR. Licenciada em Letras (Português e Inglês) pela FAFIPA e em Pedagogia pela ULBRA.

\section{CLAUDIA DE OLIVEIRA VALE}

Graduada em pedagogia pela Universidade Federal do Maranhão. Especialista em Educação Especial, Inclusão e Libras. Intérprete de Libras da rede estadual de educação, SEEDUC- MA. Mestranda em educação pela Universidade Federal do Maranhão- UFMA. Professora de libras do Instituto de Ensino Superior Franciscano- IESF. Concedido prazo até o dia 21/06/2019 para envio do cadastro. Informo que o titulo I MOSTRA SURDEZ E EDUCAÇÃO NA ESCOLA: UM OLHAR SOBRE A INCLUSÃO SURDO foi alterado para CONSIDERAÇÕES ACERCA DA I MOSTRA DE SURDEZ E EDUCAÇÃO DO IFMA CAMPUS VIANA - MA.

\section{DANIELLE BASTOS LOPES}

Professora adjunta (Dedicação Exclusiva) da Universidade do Estado do Rio de Janeiro (UERJ) no Instituto de Aplicação Fernando Rodrigues da Silveira e docente permanente do Programa de PósGraduação em Ensino de Educação Básica (PPGEB - UERJ). Doutora em Educação (PROPED - UERJ 2016); Mestre em História Social (PPGHS - UERJ - 2011) e possui graduação em Pedagogia pela mesma universidade (2005 - 2008). É coordenadora do projeto de pesquisa "Entre a terra e o céu ameríndio: currículo, cultura e diferença", financiado pela FAPERJ. Sua atual pesquisa concentra-se 
na educação entre os Mbyá (Guarani) do estado do Rio de Janeiro e aplicação da Lei 11.645/08 na educação básica. As pesquisas com influência pós-coloniais e deleuziana abrangem as grandes áreas da Educação, Filosofia e Antropologia. Tem como interesse os assuntos da cosmologia, processos de escolarização e ensino entre os povos ameríndios viventes nos territórios brasileiro e hispano-americano.

\section{DAYANE ALVES BARBOSA}

Graduanda do Curso de Gestão de Serviços de Saúde da UFMG. Foi bolsista do Projeto PIPA - Ação Multiplicadora: uma proposta de inclusão social e acessibilidade na Escola de Enfermagem da UFMG.

\section{DAYSE APARECIDA DOS SANTOS AZEVEDO}

Mestrado em Ciências da Educação pela Universidad Autónoma de Asunción -Paraguai. Professora de Pedagogia - INSTITUTOS SUPERIORES DE ENSINO DO CENSA (ISECENSA), Especialista em Psicopedagogia e Pedagogia Empresarial pelo ISECENSA (2010) e Secretária Escolar do CENTRO EDUCACIONAL NOSSA SENHORA AUXILIADORA -(CENSA). Tem experiência na área de Educação com Ensino Fundamental I, Didática Geral, Formação de Professores, Psicologia da Aprendizagem e Desenvolvimento Humano, Supervisão e Coordenação de Ensino Médio, Educação de Jovens e Adultos, Educação Especial e Reeducação Cognitiva, Modificabilidade Cognitiva Estrutural e Programa de Enriquecimento Instrumental (PEI).

\section{DIEGO SOARES SOUZA}

Graduado em Licenciatura e Bacharelado em Educação Física pela Universidade Católica de Brasília, Pós-graduação (Lato-sensu) em Educação Física Escolar pela Universidade Gama Filho (2013) e Pós-graduação (Stricto-sensu) em Mestrado em Educação Física pela Universidade Católica de Brasília (Cursando). Atualmente é professor - Secretaria de Educação do Distrito Federal e professor convidado na faculdade Mauá no curso de Educação Física em Goiânia. Tem experiência na área de Educação Física, com ênfase em Educação Física Escolar, educação, pedagogia dos jogos coletivos, natação, psicomotricidade, antropologia (estudo do corpo), biomecânica e anatomia humana.

\section{EDUARDO ALBERTO DA SILVA}

Doutor em Educação: Psicologia da Educação pela Pontifícia Universidade de São Paulo-PUC-SP (2018), Mestre em Psicologia pela Universidade Metodista de São Paulo-UMESP (2013), possui graduação em Pedagogia pela Faculdade Pitágoras de Londrina (2012), graduação em Artes Visuais pelo Centro Universitário de Jales-Unijales (2015), graduação em Psicologia pelo Centro Universitário Filadélfia (2000), especialização em Psicologia Clínica pela Universidade Estadual de Londrina (2006) e especialização em Educação Infantil pela Faculdade Dom Bosco (2015). Atualmente é professor colaborador na UNESPAR, professor em cursos de pós graduação. Atua principalmente nos seguintes temas: lúdico, arte, educação, psicologia da educação. Conferencista e palestrante em vários temas.

\section{EDWILSON DA SILVA ANDRADE}

Mestrando do Programa de Pós-Graduação em Educação da Universidade Federal Fluminense. É Especialista em Arte-Educação e Educação para Relações Étnico Raciais. Graduado em Pedagogia. É professor das séries iniciais do Ensino Fundamental da rede Municipal de Quissamã, atualmente exercendo a função de diretor pedagógico de unidade escolar. Tem experiência em tutoria, tendo atuado como bolsista no Sistema Universidade Aberta do Brasil (UAB) na categoria de Tutor a Distância, no curso de Especialização em Educação para as Relações Étnico-Raciais e também na graduação em Pedagogia ambos oferecidos pela Universidade Federal de São Carlos - UFSCar. Seus interesses de pesquisa concentram-se nos estudos do cotidiano, da educação popular e das relações étnico-raciais. 


\section{EGLECY DO ROCIO LIPPMANN}

Possui graduação em Pedagogia pela Universidade Estadual do Centro-Oeste (1983), graduação em Educação Artística pela Faculdade de Artes do Paraná (1986) e mestrado em Educação e Ensino de Professores Mestrado pelo Centro Pastoral Educacional e Assistência Dom Carlos (2002). Atualmente é professora Assistente D da Universidade Estadual do Centro-Oeste - UNICENTRO. Tem experiência na área de Artes, Educação e Educação Especial, atuando principalmente nos seguintes temas: educação, arte, ensino, arte-educação e inclusão.

\section{ELENICE MARIA FARIAS MORÃO DE MENEZES}

Licenciada em Pedagogia pelo Centro de Estudos Superiores de Parintins da Universidade do Estado do Amazonas. Especialização em Psicopedagogia pela FACIBRA/EDUCANORTE. É intérprete de Libras

\section{ELEUSY NATÁLIA MIGUEL}

Doutoranda em Economia Doméstica Universidade Federal de Viçosa (2018), Mestre em Economia Doméstica Universidade Federal de Viçosa (2016); Pós-Graduada Lato sensu de Cultura e Arte pela Universidade Federal de Ouro Preto (2016); Graduada em Arquitetura e Urbanismo pela Universidade Federal de Viçosa (2007) e Graduada em Economia Doméstica pela Universidade Federal de Viçosa (1997). Professora do curso de Arquitetura e Urbanismo da FACISA Viçosa/MG (UNIVIÇOSA) desde 2018.

\section{ELIANE MARINA PALHARES GUIMARÃES}

Graduação em Enfermagem e Obstetrícia pela PUCMINAS, doutorado em EERP/USP (2004) e mestrado em Ciências da Informação pela UFMG (1995). Professora associada II da Escola de Enfermagem da Universidade Federal de Minas Gerais/UFMG. Vice-Diretora Gestão 2010/2014 e Diretora Gestão 2014-2018 da Escola de Enfermagem da UFMG. Tem experiência na área de Enfermagem, com ênfase em Administração de Serviços de Enfermagem em Unidades de Saúde, atuando principalmente nos seguintes temas: gerência em saúde e na enfermagem, sistema de informação em saúde e na enfermagem, tecnologias educacionais, trabalho em rede e educação permanente mediatizada pela Internet.

\section{ELIENE NERY SANTANA ENES}

Mestre pelo Programa de Mestrado em Gestão Integrada do Território da Universidade Vale do Rio Doce (MG). Graduação em Psicologia pela Faculdade Dom Bosco de Filosofia, Ciências e Letras (1982), graduação em Pedagogia pela Faculdade de Filosofia Ciências e Letras de Governador Valadares (1976). Atualmente é professora dos cursos de Pedagogia e Psicologia na Universidade Vale do Rio Doce, atua também em Clínica de Psicologia/Psicanálise. Desenvolve trabalhos de ensino, pesquisa e extensão com as temáticas: Psicanálise e Educação, Diversidade e Inclusão, Território.

\section{ELTON ANDRÉ SILVA DE CASTRO}

Doutor em Psicologia (2017) pela Universidade Federal de Pernambuco (UFPE), Mestre em Desenvolvimento e Meio Ambiente (2004) e Graduado em Psicologia (2000) pela Universidade Federal de Alagoas (UFAL). É professor do Instituto Federal de Educação Ciência e Tecnologia de Pernambuco (IFPE) - Campus Afogados da Ingazeira e Líder do DesA (Grupo de Pesquisa "Processos de Desenvolvimento Humano e Aprendizagem: ambiente, cultura e subjetividade"). Tem interesse por práticas, pesquisas e reflexões sobre ciência, epistemologia, ética e bioética; produção de subjetividades contemporâneas; constituição do sujeito em diferentes contextos e a mediação da afetividade e, processos de significação e desenvolvimento humano. 


\section{ERI CRISTINA DOS ANJOS CAMPOS}

Ensino Médio (Magistério - Centro Educacional Vidal Ramos Júnior, concluído no ano de 1996). Em 2002 conclui-se graduação em Pedagogia Habilitação em Educação Infantil e Séries Iniciais, pela Universidade do Planalto Catarinense - UNIPLAC. Possui especialização em Psicopedagogia clínica e institucional e em Atendimento Educacional Especializado. Mestre em Educação pela Universidade do Planalto Catarinense - UNIPLAC. Atualmente trabalha na equipe da Educação Especial da Secretaria Municipal de Educação de Lages. Tem experiência na área de Educação, com ênfase em Ensino-Aprendizagem.

\section{ERIKA PATRÍCIA MARTINS FERREIRA}

Pedagoga e Especialista em Gestão Educacional, Educação Especial e no Ensino, Tradução e Interpretação da Língua Brasileira de Sinais; professora de Língua Brasileira de Sinais, no Instituto Federal de Educação, Ciência e Tecnologia do Maranhão - IFMA, Campus Viana.

\section{ERLANE CRISTHYNNE FELIPE DOS SANTOS}

Professora dos anos iniciais pela SEEC/RN. Mestre em Educação - UFRN/PPGED (2018), graduada em Pedagogia - UFRN (2015). Tem experiência na área de Educação, com ênfase em Educação Especial e Educação Inclusiva. Tem interesse acadêmico pela temática relacionadas à formação docente e aos processos de aprendizagem de estudantes com deficiência visual.

\section{FERNANDA COSTA SILVA}

Mestranda do Programa de Pós-Graduação em Administração do CEFET-MG. Possui Graduação em Secretariado Executivo pela Newton Paiva. Especialista em Administração Pública pela PUCMinas. Atualmente é Secretária Geral da Escola de Enfermagem da UFMG. Interesses de pesquisa ligados às áreas: Estudos Organizacionais e Estratégia, ênfase em análise institucional; Lei de Cotas; Pessoa com deficiência.

\section{FRANCINILDA RUFINO DE SOUZA}

Graduada em História pela Universidade Estadual da Paraíba - UEPB (2012). Mestra em Desenvolvimento Regional pelo Programa de Pós Graduação em Desenvolvimento Regional da UEPB/UFCG. Atuei como Professora Educadora no PROEXT MEC/SESu - UEPB (2013-2014). Fui pesquisadora do PROPESQ fazendo um levantamento sobre a implantação da Lei 10.639/03 na escola da comunidade quilombola Caiana dos Crioulos; e do PIBIC fazendo estudos sobre práticas de cura por meio de relatos orais de mulheres idosas na comunidade quilombola Caiana dos Crioulos. Tenho desenvolvido pesquisas, principalmente, nos seguintes temas: Educação, Formação Docente, História e Cultura Afro-brasileira e indígena, Memória Oral, Cultura regional nordestina e Políticas Públicas de Cultura.

\section{GISELI MONTEIRO GAGLIOTTO}

Pós-Doutorado em Psicologia (2015) pelo Observatório da Sexualidade da UNIDEP, no Departamento de Ciências Sociais e do Comportamento, do Instituto Universitário da MaiaPortugal. É Doutora em Educação (2009) pela Universidade Estadual de Campinas - UNICAMP/SP (PPG conceito 5 CAPES). Concluiu o Mestrado em Psicologia na UFSC - Universidade Federal de Santa Catarina - Florianópolis - SC no ano de 2000. Graduou-se em Psicologia na UFSC Universidade Federal de Santa Catarina - Florianópolis - SC no ano de 1997 e em Pedagogia na UDESC - Universidade do Estado de Santa Catarina em 1994. É Professora Associada A do Colegiado de Pedagogia e do Programa de Pós-Graduação Mestrado em Educação da Universidade Estadual do Oeste do Paraná - UNIOESTE, Campus de Francisco Beltrão. É líder do Laboratório e Grupo de Estudos, Pesquisas e Extensão: Educação e Sexualidade; - LABGEDUS, cadastrado no Diretório dos Grupos de Pesquisas do CNPq, coordenando a linha de pesquisa intitulada Estudos e Pesquisas Psicanalíticas e Educacionais sobre Infância, Sexualidade e Educação Sexual e sua importância para a formação docente\&quot;. Autora do livro: Educação Sexual na Escola e a 
Pedagogia da Infância: matrizes institucionais, disposições culturais, potencialidades e perspectivas emancipatórias. Paco Editorial, Jundiaí: 2014. Autora do livro: Contos de Fada e Desenvolvimento Psicossexual: o que pensam e dizem as crianças, o que fazem as professoras. Paco Editorial, Jundiaí: 2018

\section{GLAUCE VIRGINIA MOTTA REGIS}

Possui graduação em Biblioteconomia pela Universidade Federal do Estado do Rio de Janeiro (2007), graduanda Pedagogia pela Universidade Estadual do Norte- Fluminense Darcy Ribeiro (2017 até o momento), Pós graduanda em Educação Especial e Inclusiva e Neuropsicopedagogia Institucional e Inclusiva. Atualmente é bibliotecária do Instituto Superiores de Ensino do Censa. Tem experiência na área de Educação, com ênfase em bibliotecas: escolar, universitária.

\section{GLÁUCIA PEREIRA LIMA}

Especialista em Educação Especial pela UEL, Graduada em Ciências Sociais pela UEL. Professora do SAREH SME Londrina/PR.

\section{GLAYDSON DE OLIVEIRA SOARES}

Graduado em Nutrição pela Faculdade Católica Salesiana do Espírito Santo (2011) e Licenciando em Educação Profissional pelo Instituto Federal de Brasília (IFB), Mestrando em Educação Física pela Universidade Católica de Brasília (UCB), Especialista em Nutrição Clínica pelo Programa de Residência da Secretaria de Estado de Saúde do Distrito Federal/ ESCS (2016). Atua como nutricionista clínico em área hospitalar. Possui experiência como docente pela Secretaria de Estado de Educação do Distrito Federal. É integrante do Grupo de Estudo em Fisiologia do Exercício e Saúde (GEFES) da Universidade Católica de Brasília (UCB). Atualmente desenvolve pesquisa científica de suplementação nutricional em indivíduos com doença renal crônica em tratamento hemodialítico.

\section{HELOISA VALERIA MANGIA TORRES}

Professora do Colégio Pedro II desde 2010. Doutora em Literatura Comparada e Mestre em Literatura Brasileira pela Universidade do Estado do Rio de Janeiro (UERJ). No presente artigo, a paixão pela literatura se aliou ao prazer de ensinar e à busca de romper o paradoxo entre a enorme potencialidade de estudantes portadores de deficiência visual e as inúmeras dificuldades que enfrentam no dia a dia.

\section{JANAINA DA CRUZ MARTINS LIZZE}

Graduada em Pedagogia pela Universidade Estadual de Maringá. Especialização em Coordenação Pedagógica pela UFPR. Professora dos anos iniciais do ensino fundamental e pedagoga dos anos finais do ensino fundamental da rede pública.

\section{JAQUELINE TUBIN FIEIRA}

Graduada em Psicologia pela Universidade Bandeirantes (2009). Mestre em Educação pelo Programa de Pós-graduação da Universidade Estadual do Oeste do Paraná (2017). Possui especialização MBA em Recursos Humanos pela Univel (2011). Pesquisadora do grupo de estudos "Educação e Sociedade" (GEDUS) da UNIOESTE - Francisco Beltrão/PR. Tem experiência na área de Educação, atuado como orientadora educacional da educação infantil do Colégio Unisep e na Associação de Proteção aos Autistas de Dois Vizinhos (APADV). Atuou na área de Recursos Humanos, como psicóloga organizacional, com foco na educação corporativa na empresa Latreille. Atualmente é professora de Psicologia na União de Ensino do Sudoeste do Paraná (UNISEP) campus Francisco Beltrão e Dois Vizinhos, desde 2010 e na Pós-graduação desde 2017. Atua como Psicóloga clínica, com a abordagem psicanalítica, no Centro Clínico Oasis. Realiza palestras na área da educação, educação sexual e na área de gestão de pessoas. 


\section{JEFFERSON DIEGO DE JESUS}

Professor Surdo, Mestre na linha pesquisa políticas educacionais - UFPR. Especialista em Educação Bilíngue para surdos, graduado em Letras Libras. Professor na Universidade Federal do Paraná.

\section{JOAQUIM BRAGA}

Especialista em Educação Profissional Integrada à Educação Básica na Modalidade para Jovens e Adultos pela UTFPR. Licenciado em Letras pela UEL. Professor do SAREH-SEED/PR.

\section{JODELMA CASTELO BRANCO MENDES}

Graduada em Pedagogia pela Universidade Federal do Maranhão, Especialista em Gestão, Supervisão e Orientação Educacional pela Faculdade Santa Fé, Pedagoga no Instituto Federal de Educação, Ciência e Tecnologia do Maranhão. Exerce o cargo de Diretora de Desenvolvimento Educacional no IFMA Campus Viana desde 2016.

\section{JOMAR RICARDO DA SILVA}

Possui graduação em História (1991), Especialista em Brasil República (1995), Mestrado em Sociologia (1998), pela Universidade Federal da Paraíba (atualmente Universidade Federal de Campina Grande, UFCG, Campus I) e doutorado em Educação pela Universidade Federal do Rio Grande do Norte (2007). É professor Associado da Universidade Estadual da Paraíba. Tem experiência na área de Sociologia, atuando nos temas cidadania e participação social.

\section{JORDANA RABELO SOARES}

Possui graduação em Biblioteconomia pela UNIFOR (2003). Especialização em Biblioteconomia e Documentação (2010)Atualmente é bibliotecária na Escola de Enfermagem da Universidade Federal de Minas Gerais. Trabalha com normalização e correção dos artigos publicados na REME Revista Mineira de Enfermagem. Realiza a edição e indexação dos artigos da REME nas bases de dados BDENF e LILACS. Trabalha no controle bibliográfico da Biblioteca Virtual de Saúde Enfermagem (BVS) e coordenação dos bibliotecários da REDE Enfermagem Lilacs/ Bireme AL\&C. Tem experiência na área de Ciência da Informação, com ênfase em Biblioteconomia.

\section{JULIANNA MENDES DE MATOS SOUZA}

Possui graduação em Pedagogia pela Universidade de Brasília (2009). Especialização em Orientação Educacional pela Facibra (2013). Especialização em Docência na Educação Infantil pela Universidade de Brasília (2015). Mestranda em Educação Física pela Universidade Católica de Brasília (2019). Atualmente é professora - Secretaria de Educação do Distrito Federal. Tem experiência na área de Educação, com ênfase em Educação Infantil, Educação Especial e Educação Precoce.

\section{KELLY JESSIE QUEIROZ PENAFIEL}

Doutoranda em Educação pela Universidade Federal de Minas Gerais (UFMG). Integrante do Grupo de Estudos e Pesquisas em Psicologia Histórico-Cultural na Sala de Aula (GEPSA) e do Grupo de Estudos em Cultura, Educação e Infância (EnlaCEI), ambos da FaE/UFMG. Graduada em Pedagogia (2009) e mestre em Psicologia (2012) pela Universidade Federal de Rondônia (UNIR), com estágio sanduíche na Universidade de São Paulo (USP). Especialista em Educação Infantil pela Universidade Católica Dom Bosco (UCDB) e em Alfabetização e Letramento pela Universidade Municipal de São Caetano do Sul (USCS). Integrante do Grupo de Estudos Pedagógicos (GEP) na linha de pesquisa Psicologia e Aprendizagem Escolar. Professora da Universidade Federal de Rondônia (UNIR), campi Vilhena, na área de ensino-aprendizagem. 


\section{LETÍCIA JAFAR DA FONSECA}

Mestranda do Programa de Pós-Graduação em Administração do CEFET-MG. Possui Graduação em Ciências Biológicas pela PUCMINAS. MBA em Gestão de Projetos pela UNA. Atualmente é servidora TAE da UFMG. Interesses de pesquisa ligados às áreas: Estudos Organizacionais e Estratégia, ênfase em análise institucional; Lei de Cotas; Pessoa com deficiência.

\section{LUIZ ANDRÉ BRITO COELHO}

Professor surdo- UTFPR, especialista em educação bilíngue para surdos, pesquisador na área da surdez, graduado em matemática e Letras Libras; Mestrando pela UTFPR-PG (Mestrado Profissionalizante).

\section{LURDES CARON}

Possui graduação em Pedagogia pela Faculdade de Filosofia Ciências e Letras do Vale do Itajaí (1975), mestrado em Teologia Prática - Educação Cristã pela Escola Superior de Teologia Instituto Ecumênico de Pós Graduação (1995) e Doutorado em Educação: Currículo - pela Pontifícia Universidade Católica de São Paulo (2007), Pós-Doutoral em Educação e Religião pela PUCPR em 2016. É associada do Fórum Nacional Permanente do Ensino Religioso - FONAPER. Fez parte do Grupo de Assessoria e Pesquisa, do Setor de Ensino Religioso, da Conferência Nacional dos Bispos do Brasil - CNBB - (GRAPER/CNBB). Associada da Associação Catarinense de Professores de Santa Catarina. Docente Pesquisadora do Mestrado Acadêmico em Educação - da Universidade do Planalto Catarinense, é professora titular e, professora na graduação da Universidade do Planalto Catarinense. Faz parte da Comissão Institucional de Acessibilidade - CIA da UNIPLAC. Tem experiência na área de educação e gestão, com ênfase em Ciências Humanas, atuando principalmente nos seguintes temas: formação de professores, ensino religioso, metodologia e história do ensino religioso, educação especial, currículo, legislação, gestão, pesquisa e prática pedagógica e metodologia de pesquisa. Coordenadora do Grupo de Pesquisa: FORMAÇÃO DE PROFESSORES: POLÍTICAS CURRICULARES E PRÁTICAS INCLUSIVAS PARA A CULTURA DA PAZ NA EDUCAÇÃO - FORPAZ. Autora de vários livros sobre Formação de Professores de Ensino Religioso e Educação Especial, Avaliação: Políticas e Práticas.

\section{MARCELO ELISIO VASICKI}

Professor Surdo- UEPG, foi presidente da Associação de Surdos de Curitiba, graduado em Letras Libras pela UFSC, Atualmente cursa o Mestrado Profissionalizante na UTFPR/PG

\section{MARCIA RAIKA E SILVA LIMA}

Doutora em Educação/UFPI (2016), Mestrado em Educação/ UFPI (2010). Especialização em Educação Inclusiva e Especial com ênfase em Neurociência (cursando). Especialista em Supervisão Escolar/UFPI, em Gestão Educacional/ UNICESP e em Língua Brasileira de Sinais, possui Graduação em Licenciatura Plena em Pedagogia/UFPI. Professora Adjunta 1 da UEMA/ Centro de Estudos Superiores de Caxias. Professora do Mestrado Profissional em Educação Inclusiva UNESP/UEMA. Foi Gerente de Educação Especial do Estado do Piauí (2011-2014), trabalhou no Núcleo de Atividades de Altas Habilidades/Superdotação (2007-2008), professora substituta da UEMA -Timon-MA (2011-2012) e como professora convidada da Faculdade Santo Agostinho. Tem experiência na área de Educação, trabalhando com as diferentes disciplinas da área da Pedagogia, com ênfase em Educação Especial e Inclusiva e LIBRAS. Participou do Núcleo de Estudos e Pesquisas em Educação na Psicologia Sócio-Histórica (UFPI). Participa do Grupo de Pesquisas Interdisciplinares: educação, saúde e sociedade e do Grupo de Estudos e Pesquisas Interdisciplinar do Centro de Estudos Superiores de Caxias (GEPICESC). 


\section{MÁRCIA VERÔNICA COSTA MIRANDA}

Possui graduação em Técnico Em Nível Superior Em Processamento de Dado pela Universidade Federal da Paraíba (1985), hoje intitulado Sistemas de Informações, mestrado em Ciência da Computação pela Universidade Federal da Paraíba (1996) e doutorado em Doutorado em Engenharia Elétrica pela Universidade Federal de Campina Grande (2003). Atualmente, é professora associada da Universidade Federal da Paraíba. Tem experiência na área de Engenharia Elétrica, com ênfase em Engenharia da Computação, atuando principalmente nos seguintes temas: Tecnologia da Informação e Comunicação, Educação, Inclusão social, Informática e inclusão digital. Desenvolve e executa diversos projetos na área de extensão universitária, notadamente Extensão rural, com temática na Educação e Inclusão social e digital.

\section{MARIA APARECIDA PEREIRA}

Graduada em Serviço Social pela Universidade Federal da Paraíba - UFPB, com experiência na área da Educação, onde atuou em temas como Programa Bolsa Família e suas condicionalidades, Serviço Social, Inclusão Escolar, Bullying, Violência na Escola. Em 2015 foi colaboradora na primeira fase do Projeto de Extensão (PROBEX) intitulado O PROGRAMA BOLSA FAMÍLIA (PBF) E SUAS CONDICIONALIDADES NA EDUCAÇÃO: o acompanhamento e monitoramento dos(as) alunos(as) em descumprimento na Escola Municipal Nazinha Barbosa da Franca. Em 2016 foi bolsista na $2^{\text {a }}$ fase do supracitado Projeto de Extensão. Pesquisadora do Projeto de Pesquisa intitulado "Prisão e Educação um hiato histórico: da cela à sala de aula, um caminho para a educação ao longo da vida?". Autora do livro Violência Escolar - Aspectos que contribuem para essa prática, publicado em 2017 pela Editora Novas Edições Acadêmicas, Düsseldorf, Alemanha.

\section{MARIA DE FÁTIMA LEITE GOMES}

Possui graduação em Serviço Social pela Universidade Federal da Paraíba (1987), Especialização em Metodologia das Ciências pela Universidade Estadual da Paraíba (1991), Mestrado em Serviço Social pela Universidade Federal da Paraíba (1997) e Doutorado em Serviço Social pela Universidade Federal de Pernambuco (2011), na Área de Concentração em Serviço Social, Movimentos Sociais e Direitos Sociais. É professora da Universidade Federal da Paraíba atuando na Graduação e no Programa de Pós-Graduação em Serviço Social da Universidade Federal da Paraíba (UFPB).. Tem experiência na área de Serviço Social, com ênfase em Política de Assistência Social, Fundamentos do Serviço Social e Movimentos Sociais. Foi Chefe do Departamento de Serviço Social da UFPB, no período 2001-2006, e Vice-Presidente Regional da Associação Brasileira de Ensino e Pesquisa em Serviço Social (ABEPSS), no período 2003-2004. Ministrou disciplinas na PósGraduação (lacto-sensu) em Serviço Social da UFPB, além de participação em Cursos de formação de curta duração. Foi colaboradora do Conselho Municipal de Assistência Social (CMAS), de João Pessoa-PB., entre 2013-2014. Orienta e coordena projeto de extensão e projetos de iniciação científica (PIBIC e PIVIC), vinculados à UFPB e ao CNPQ, respectivamente. É a segunda líder do Grupo de Estudos e Pesquisas em Educação Popular, Serviço Social e Movimentos Sociais (GEPEDUPSS), vinculado ao Departamento de Serviço Social e ao Programa de Pós-Graduação em Educação (PPGE), da UFPB. Foi Membro da Associação Latinoamericana de Sociologia, no período correspondente a 2013-2015. É vice-chefe do Departamento de Serviço Social da UFPB, desde 2016.

\section{MARIA DE LOURDES ZACARIAS DA SILVA}

Graduada em Serviço Social pela Universidade Federal da Paraíba. Possui experiência nas Políticas de Saúde Mental, Política de Assistência Social e Política de Educação, atuando principalmente nas seguintes temáticas: Usuários Crônicos, Desinstitucionalização, Serviços Substitutivos, Violências e Violações de Direitos, Crianças, Adolescentes e Famílias, Vulnerabilidade, Proteção Social, Programa Bolsa Família e suas Condicionalidades. Participou como pesquisadora da pesquisa intitulada: Violação de direitos e vulnerabilidade social de crianças e adolescentes e famílias no Estado da Paraíba e as políticas de enfrentamento. Vinculada ao grupo de estudos e pesquisa sobre crianças, adolescentes e famílias (GEPAC), ao departamento de serviço social (DSS) e ao programa de pós-graduação e serviço social (PPGSS) da universidade federal da Paraíba (UFPB). 


\section{MARIA DO SOCORRO DE SOUSA}

Licenciada em Pedagogia e Especialista em Gestão de Políticas Públicas em Gênero e Raça (UFPI). Bacharel em Biblioteconomia (UESPI). Bibliotecária no Instituto Federal de Educação, Ciência e Tecnologia do Maranhão - IFMA, Campus Viana

\section{MARIA GORETTI RODRIGUES DE SOUSA OLIVEIRA}

Graduada em Serviço Social pela Universidade Federal da Paraíba (UFPB), experiência na Educação. Com ênfase nos seguintes temas: Educação, Programa Bolsa Família e suas condicionalidades, Serviço Social, Inclusão Escolar, Bullying, Violência na Escola. 2015 Colaboradora na primeira fase do Projeto de Extensão intitulado O PROGRAMA BOLSA FAMÍLIA (PBF) E SUAS CONDICIONALIDADES NA EDUCAC̄̃̃O: o acompanhamento e monitoramento dos(as) alunos(as) em descumprimento na Escola Municipal Nazinha Barbosa da Franca .2016, Bolsista na segunda fase do referido Projeto. 2016 Bolsista na segunda fase do Projeto supracitado; Desenvolveu atividade de Monitora Voluntária no PROJETO DE MONITORIA da disciplina Ética em Serviço Social, orientada pela Profa ${ }^{2}{ }^{a}$ M ${ }^{a}$ de Fátima Leite Gomes. Pesquisadora do Projeto de Pesquisa intitulado "Prisão e Educação um hiato histórico: da cela à sala de aula, um caminho para a educação ao longo da vida?". 2017- Autora do livro Violência Escolar - Aspectos que contribuem para essa prática, Editora Novas Edições Acadêmicas, Düsseldorf, Alemanha 2018.Graduanda em Psicopedagogia pela Universidade Federal da Paraíba (UFPB)2019.

\section{MARIA ROSELENE SOARES MARQUES}

Sou estudante de Letras Português Literaturas da Universidade Federal do Rio de Janeiro (UFRJ). Estou no quarto período da graduação e, até o presente momento, atuei como palestrante em algumas mesas que versavam sobre a relação da pessoa com deficiência visual e a literatura; a mulher com deficiência na sociedade e participei da mesa "Inclusão ou inserção". Participei também do Congresso Nacional de Práticas Inclusivas (CONAPI), palestrando sobre o conteúdo do presente artigo. Sou uma estudante que, aprende diariamente a lidar com os diversos desafios impostos pela sociedade. Transformo-os em incentivo para provar, não para o mundo, mas para mim o quão sou capaz de vencer as minhas limitações. Utilizar a literatura como meio de compartilhar um pouco dos desafios e aprendizados que me fizeram crescer bastante como pessoa é algo imensamente gratificante.

\section{MARIANA SANTANA FACINA}

Graduada em Pedagogia pela Universidade Estadual de Maringá. Especialização em Psicopedagogia, Neuropsicopedagogia e Educação Especial e Inclusiva pela Faculdade de Ensino Superior Dom Bosco. Especialização em Gestão Escolar Integrada e Práticas Pedagógicas pela Faculdade Eficaz. Professora mediadora na Unicesumar - EAD.

\section{MARINÊS DIAS GONÇALVES}

Possui graduação em Pedagogia Educação Especial (2001), Especialização em Educação Especial (2007) e Mestrado em Educação (2017). Proficiente no uso da Língua Brasileira de Sinais (Libras). Atualmente é docente no Instituto Federal Catarinense - Campus Rio do Sul. Tem experiência na área de Educação Especial, atuando principalmente nos seguintes temas: libras e educação inclusiva.

\section{MARIO CÉZAR ALVES FERREIRA}

Mestre em Educação pela UTFPR. Especialista em Educação Especial pela UNOPAR e em Educação de Jovens e Adultos pela UEL. Licenciado em História pela UEL. Professor do SAREH-SEED/PR. 


\section{MARTHA CAROLINE DUARTE DE BRITO FREITAS}

Mestre em Cognição e Linguagem (UENF). Professora de Língua Portuguesa, atuando com turmas do $2^{\circ}$ ciclo do Ensino Fundamental. Tutora presencial no curso de Licenciatura em Letras (UNOPAR). Experiência em Cursos Pré-Vestibular e Pré-Técnico. Licenciada em Letras pela Faculdade de Filosofia de Campos (2009). Possui Pós-graduação lato sensu em Língua Portuguesa e Literatura Brasileira pela FACEL/PR. Seus interesses de pesquisa concentram-se nos seguintes temas: crença de autoeficácia, linguagem, escrita, gramática, ENEM, literatura brasileira, autorregulação da aprendizagem (psicologia da aprendizagem) e metodologias de ensino.

\section{MAYCON CESAR PEREIRA WERNZ}

Atualmente, professor de Língua Portuguesa/ Inglesa do IFMA campus Viana. Tem experiência na área de Lingüística, com ênfase em Linguística Textual, atuando principalmente nos seguintes temas: gêneros e discurso, retextualização e leitura.

\section{NÁDIA MAROTA MINÓ}

Doutoranda (fase conclusiva) pelo Programa de Pós-Graduação em Economia Doméstica/PPGED (Famílias Políticas Públicas e Desenvolvimento Humano e Social) pela Universidade Federal de Viçosa (UFV). Bolsista da Fundação CAPES. Mestre pelo PPGED/UFV (2016). Licenciada em Pedagogia UFV (2013). Colaboradora voluntária do Projeto de Extensão "Esta Ruga tem História?" no Programa Municipal da Terceira Idade - PMTI/Parceria entre a UFV e Prefeitura Municipal de Viçosa. Período: 2013 à 2016.

\section{NISIA CAMARGO CAETANO DI NIZO FANTINELLI}

Mestranda pela Universidade Estadual do Norte do Paraná (UENP) Campus Cornélio Procópio Programa de Pós-graduação em Ensino (PPGEN) Mestrado Profissional em Ensino. Pós-graduada em Psicopedagogia Institucional, Clínica e educação Especial - Faculdade Venda Nova do Imigrante (FAVENI). Pós-graduada em Docência no Ensino Superior - Faculdade São Braz. Graduada em Pedagogia - Faculdade educacional da Lapa (FAEL).

\section{PASCOAL ERON SANTOS DE SOUZA}

Mestre em Educação e Diversidade pelo Programa de Pós-Graduação em Educação e Diversidade PPED/MPED pela Universidade do Estado da Bahia - UNEB (2017). Tem especialização em Educação, Cultura e Contextualidade pela UNEB (2010); especialização em Psicopedagogia pela Faculdade Internacional de Curitiba- FACINTER/IBPEX (2002) e em Ensino da Língua Inglesa pela Universidade de Pernambuco - UPE (2006). Licenciatura em Pedagogia pela UNEB (2001) e Licenciatura em Língua Inglesa e suas Literaturas pela UPE (2007). É professor do Departamento de Educação do Campus VII/UNEB. Desenvolve estudos na área de Educação, com ênfase em Educação Inclusiva, Didática, Educação de Surdos, Pesquisa e Prática Pedagógica, e Ensino da Língua Inglesa.

\section{RENATA GRECO DE OLIVEIRA}

Graduada em Pedagogia pela Universidade Vale do Rio Doce. Especialista em Docência do Ensino Superior. Mestre em Educação pela Universidade Federal do Rio Grande Sul. Professora no Ensino Superior desde 2002: Faculdade de Mantena (2002-2005), Universidade Presidente Antônio Carlos (2005-2009), Universidade Vale do Rio Doce - UNIVALE (2011-atual). Atuou como Coordenadora Institucional do PIBID-UNIVALE, e do curso de Pedagogia da UNIVALE e como representante do Ensino Superior no Conselho Municipal da Educação (CME) de Governador Valadares. Tem experiência na área de Educação, com ênfase em Pesquisa em Educação, nos seguintes temas: formação política, identidade, aprendizagem, universidade e educação à distância. Atualmente atua com extensão. 


\section{RENNER DOUGLAS GONÇALVES DUTRA}

Mestre em Educação e Ensino de Ciências na Amazônia pela Universidade do Estado do Amazonas (2014), Especialização em Educação de Jovens e Adultos pela Universidade Federal do Amazonas (1996), Bacharelado em Teologia pela Pontifícia Universidade Católica do Rio de Janeiro (1987), Licenciatura em Filosofia pela Universidade Estadual do Ceará (1996), Curso de Filosofia pela Faculdade Eclesiástica de Filosofia João Paulo II - Arquidiocese do Rio de Janeiro (1983). Professor concursado da Universidade do Estado do Amazonas. Tem experiência nas áreas de Filosofia e Sociologia com ênfase em Filosofia da Educação, Religião, Cultura e da Sociologia da Infância

\section{RICARDO JOSÉ ROCHA AMORIM}

Possui Pós Doutorado, Doutorado e Graduação em Ciência da Computação. Atualmente, exerce atividades docentes na graduação e em programas de pós-graduação Stricto Sensu. Coordena projeto de pesquisa no INES - Instituto Nacional de Ciência e Tecnologia para Engenharia de Software, atuando na área de Ciência da Computação com ênfase em Inteligência Artificial, Representação de Conhecimento e Engenharia de Software. Também, atua na área de Informática na Educação, com ênfase em Ontologia Educacional, Padrões de Metadados Educacionais, Objetos de Aprendizagem, Learning Design e Learning Analytics.

\section{RONALDO QUIRINO DA SILVA}

Mestre em Distúrbios da Comunicação e Linguagem, especialista em educação bilíngue para surdos, graduado em pedagogia, pesquisador da área da surdez. Professor no ensino superior e diretor da empresa Librandus "Excelência na Língua de Sinais".

\section{ROSANE DA SILVA NUNES}

Professora de Jornalismo da Universidade Federal do Cariri (UFCA), doutoranda em Educação (UFRN), mestra em Desenvolvimento e Meio Ambiente (UFC), especialista em Gestão da Comunicação (UFC), graduada em Comunicação Social - Jornalismo (UFC). Integrante do Grupo de Pesquisa Estudos de Mídia - Análises e pesquisa em cultura, processos e produtos midiáticos (UFRN).

\section{SÂMMYA FARIA ADONA LEITE}

Tem experiência na área de Educação, com ênfase em DIDÁTICA, PRÁTICAS DE ENSINO, ASPECTOS PEDAGÓGICOS, EDUCAÇÃO A DISTÂNCIA, COMUNICAÇÃO, PSICOMOTRICIDADE, ARTE E EDUCAÇÃO.

\section{SEPHORA SANTANA SOUZA}

Pedagoga formada pela Universidade Federal do Maranhão, atua como professora de educação infantil pela prefeitura de Icatu, atuou como: professora formadora do ESCOLA DA TERRA, professora (Educ. Infantil) em São José de Ribamar, técnico de educação - supervisão pedagógica no SENAI, professora e ex-extensionista do PRONERA/UFMA, pesquisadora e membro do NEPHECC( Núcleo de Estudos e Pesquisas em História,Politica e Educação do Campo).Onde participou enquanto pesquisadora da Pesquisa intitulada "Terra e Educação: a história da Participação dos Movimentos Sociais do Campo e das Familias Assentadas e Áreas de Reforma Agraria no Estado do Maranhão). Hoje atua principalmente nos seguintes temas: formação de professores, gestão escolar, escolas multisseriadas, Educação do Campo, PSICOLOGIA DA EDUCAÇÃO, ESCOLA DA TERRA, PRONERA, Projeto Político Pedagógico e Saber Social." 


\section{SILVANA CAROLINA FURSTENAU DOS SANTOS}

Cursa Doutorado em Educação Física, pela Universidade Católica de Brasília - UCB, bolsista PROSUC/CAPES. Mestre em Educação Física - UCB. Especialista em Psicopedagogia; Pedagogia Empresarial; Gestão e Orientação Educacional; Docência do Ensino Superior, Profissional e Tecnológico. Licenciada em Educação Física e em Pedagogia. Atua como docente da Universidade Paulista - UNIP, nos cursos de Gestão de Recursos Humanos, Pedagogia e Fisioterapia. É docente no Centro Universitário ICESP, nos cursos de Educação Física e Fisioterapia. Docente no Instituto Brasileiro de Ensino e Cultura - DF, no curso de Educação Física. É membro do Comitê de Ética e Pesquisa do Centro Universitário ICESP.

\section{SILVANA ELISA DE MORAIS SCHUBERT}

Doutora e mestre em educação, especialista em educação especial, educação infantil e educação bilíngue para surdos. Professora do ensino superior FAEL, UTP/PR, e educação básica na prefeitura de Araucária, pesquisadora e escritora na área da surdez e literatura infantil, psicanalista pela Associação Brasileira de Psicanálise INSIGHT.

\section{SIMONE SOUZA SILVA}

Doutora em Educação pelo Programa de Pós-Graduação em Educação da Universidade Federal do Amazonas. Mestre em Educação e Ensino de Ciências pelo Programa de Pós-Graduação em Educação e Ensino de Ciências na Amazônia pela Universidade do Estado do Amazonas. Licenciada em Pedagogia pela Universidade Federal do Amazonas. É professora de Graduação e de PósGraduação no Centro de Estudos Superiores de Parintins da Universidade do Estado do Amazonas, ministrando as disciplinas de Metodologia do Estudo, Didática, Epistemologia da Pesquisa Educacional, Pesquisa e Prática Pedagógica I, Pesquisa e Prática Pedagógica II e Estágio. Tem experiência na área de Educação, com ênfase em educação científica, currículo, formação inicial de professores, trabalho docente e educação do campo.

\section{VALÉRIA LEITE DA SILVA}

Graduada em Pedagogia pela Universidade Federal de Rondônia (UNIR). Pós-graduada em Práticas na Docência Infantil pela FAEL.

\section{WILLIAMS ALVES XAVIER}

Graduando em Agronomia pela Universidade Federal da Paraíba - Campus II, atualmente é voluntário em projetos de extensão universitária do Departamento de Ciências Fundamentais e Sociais, na área de inclusão rural através da informática. Também é estagiário do Departamento de Fitotecnia do centro e foi monitor bolsista das disciplinas de Informática e Química Orgânica. É Técnico em Administração formado pela Escola Técnica Miguel Arraes de Alencar - PE, e durante o ensino médio realizou intercâmbio na Harbour View High School - Canadá.

\section{WYLKER SOUZA SARAIVA}

Mestrando em Educação Física UCB- Universidade Católica de Brasília-Graduado em Educação Física 2001/1 no Centro Universitário UNIRG. Especialização em Educação Física com ênfase em treinamento Esportivo (Iep-Marabá-PA). Atualmente professor substituto do Curso de Educação Física do Centro Universitário Unirg e em 2015/2 começa a exercer sobre regime estatuário no Município de Gurupi o cargo de Professor de Educação Física. Professor destaque da área da Educação Física pelo Prêmio Professores do Brasil do ano de 2017. 


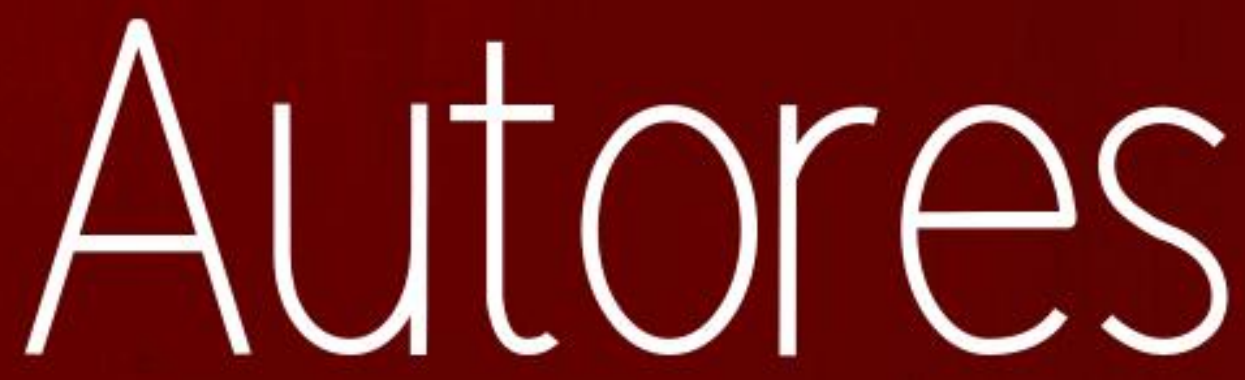




\section{ALINE ANTONIA SANTOS LINS}

Pedagoga. Psicopedagoga. Especialista em Atendimento Educacional Especializado. Cursando Especialização em Práticas Assertivas da Educação Profissional integradas à EJA. Técnica em Assuntos Educacionais no Instituto Federal de Ciência e Tecnologia do Maranhão-IFMA

\section{ALINE FROLLINI LUNARDELLI}

Professora do Departamento de Fundamentos da Educação da Universidade Estadual de Maringá UEM. Doutora em Psicologia Escolar e do Desenvolvimento Humano pela Universidade de São Paulo - USP- SP.

\section{ANA CARLA SEVERO ANDRADE}

Licenciada em Pedagogia pela Universidade do Estado da Bahia - UNEB (2016). Tem especialização em Libras - Educação de Surdos pela Universidade Norte do Paraná - UNOPAR (2017). Professora da UNILATUS e da Faculdade de Candeias - FAC e educadora dos anos finais do Ensino Fundamental. Desenvolve projetos de inclusão de surdos no Núcleo de Educação Especial de Itiúba - NEEI; Especialização em andamento em Letras/Libras - UNEB. Experiência na área de Linguística, com ênfase em Língua Brasileira de Sinais.

\section{ANMALY NATÁLIA MIGUEL MONTEIRO GILBERT}

Licenciada em Pedagogia pela Universidade Federal de Viçosa. Foi voluntária no projeto "Heart for Orphans", realizado com crianças carentes em duas instituições na Cidade do Cabo, África do Sul. Realizou Intercâmbio para a Universidade do Porto, Portugal, durante um semestre (seis meses), iniciado em setembro de 2014 e concluído em fevereiro de 2015. Foi bolsista do projeto "Percepção do ambiente degradado e propostas de intervenções a partir dos conhecimentos construídos pelos alunos assistidos pela APOV", onde atuou como professora. Realizou também estágios supervisionados em Educação Infantil, Ensino Fundamental, Educação especial e Gestão Escolar. Além disso, participou e organizou diferentes eventos durante o curso de Pedagogia. Exerceu o cargo de Coordenadora Pedagógica do Ensino Fundamental na Secretaria Municipal de Educação de Viçosa/MG. Está cursando o segundo ano do Mestrado em Educação pela Universidade Federal de Viçosa, onde atua na área de Metodologias Ativas.

\section{APARECIDA RAMAZOTTI DE CAMARGO}

Mestre em Geografia pela UEL. Especialista em Pedagogia para o Ensino Religioso pela PUCPR. Licenciada em Letras (Português e Inglês) pela FAFIPA e em Pedagogia pela ULBRA.

\section{CLAUDIA DE OLIVEIRA VALE}

Graduada em pedagogia pela Universidade Federal do Maranhão. Especialista em Educação Especial, Inclusão e Libras. Intérprete de Libras da rede estadual de educação, SEEDUC- MA. Mestranda em educação pela Universidade Federal do Maranhão- UFMA. Professora de libras do Instituto de Ensino Superior Franciscano- IESF.

\section{DANIELLE BASTOS LOPES}

Professora adjunta (Dedicação Exclusiva) da Universidade do Estado do Rio de Janeiro (UERJ) no Instituto de Aplicação Fernando Rodrigues da Silveira e docente permanente do Programa de PósGraduação em Ensino de Educação Básica (PPGEB - UERJ). Doutora em Educação (PROPED - UERJ 2016); Mestre em História Social (PPGHS - UERJ - 2011) e possui graduação em Pedagogia pela mesma universidade (2005 - 2008). É coordenadora do projeto de pesquisa "Entre a terra e o céu ameríndio: currículo, cultura e diferença", financiado pela FAPERJ. Sua atual pesquisa concentra-se na educação entre os Mbyá (Guarani) do estado do Rio de Janeiro e aplicação da Lei 11.645/08 na educação básica. As pesquisas com influência pós-coloniais e deleuziana abrangem as grandes áreas da Educação, Filosofia e Antropologia. Tem como interesse os assuntos da cosmologia, 
processos de escolarização e ensino entre os povos ameríndios viventes nos territórios brasileiro e hispano-americano.

\section{DAYANE ALVES BARBOSA}

Graduanda do Curso de Gestão de Serviços de Saúde da UFMG. Foi bolsista do Projeto PIPA - Ação Multiplicadora: uma proposta de inclusão social e acessibilidade na Escola de Enfermagem da UFMG.

\section{DAYSE APARECIDA DOS SANTOS AZEVEDO}

Mestrado em Ciências da Educação pela Universidad Autónoma de Asunción -Paraguai. Professora de Pedagogia - INSTITUTOS SUPERIORES DE ENSINO DO CENSA (ISECENSA), Especialista em Psicopedagogia e Pedagogia Empresarial pelo ISECENSA (2010) e Secretária Escolar do CENTRO EDUCACIONAL NOSSA SENHORA AUXILIADORA -(CENSA). Tem experiência na área de Educação com Ensino Fundamental I, Didática Geral, Formação de Professores, Psicologia da Aprendizagem e Desenvolvimento Humano, Supervisão e Coordenação de Ensino Médio, Educação de Jovens e Adultos, Educação Especial e Reeducação Cognitiva, Modificabilidade Cognitiva Estrutural e Programa de Enriquecimento Instrumental (PEI).

\section{DIEGO SOARES SOUZA}

Graduado em Licenciatura e Bacharelado em Educação Física pela Universidade Católica de Brasília, Pós-graduação (Lato-sensu) em Educação Física Escolar pela Universidade Gama Filho (2013) e Pós-graduação (Stricto-sensu) em Mestrado em Educação Física pela Universidade Católica de Brasília (Cursando). Atualmente é professor - Secretaria de Educação do Distrito Federal e professor convidado na faculdade Mauá no curso de Educação Física em Goiânia. Tem experiência na área de Educação Física, com ênfase em Educação Física Escolar, educação, pedagogia dos jogos coletivos, natação, psicomotricidade, antropologia (estudo do corpo), biomecânica e anatomia humana.

\section{EDUARDO ALBERTO DA SILVA}

Doutor em Educação: Psicologia da Educação pela Pontifícia Universidade de São Paulo-PUC-SP (2018), Mestre em Psicologia pela Universidade Metodista de São Paulo-UMESP (2013), possui graduação em Pedagogia pela Faculdade Pitágoras de Londrina (2012), graduação em Artes Visuais pelo Centro Universitário de Jales-Unijales (2015), graduação em Psicologia pelo Centro Universitário Filadélfia (2000), especialização em Psicologia Clínica pela Universidade Estadual de Londrina (2006) e especialização em Educação Infantil pela Faculdade Dom Bosco (2015). Atualmente é professor colaborador na UNESPAR, professor em cursos de pós graduação. Atua principalmente nos seguintes temas: lúdico, arte, educação, psicologia da educação. Conferencista e palestrante em vários temas.

\section{EDWILSON DA SILVA ANDRADE}

Mestrando do Programa de Pós-Graduação em Educação da Universidade Federal Fluminense. É Especialista em Arte-Educação e Educação para Relações Étnico Raciais. Graduado em Pedagogia. É professor das séries iniciais do Ensino Fundamental da rede Municipal de Quissamã, atualmente exercendo a função de diretor pedagógico de unidade escolar. Tem experiência em tutoria, tendo atuado como bolsista no Sistema Universidade Aberta do Brasil (UAB) na categoria de Tutor a Distância, no curso de Especialização em Educação para as Relações Étnico-Raciais e também na graduação em Pedagogia ambos oferecidos pela Universidade Federal de São Carlos - UFSCar. Seus interesses de pesquisa concentram-se nos estudos do cotidiano, da educação popular e das relações étnico-raciais.

\section{EGLECY DO ROCIO LIPPMANN}


Possui graduação em Pedagogia pela Universidade Estadual do Centro-Oeste (1983), graduação em Educação Artística pela Faculdade de Artes do Paraná (1986) e mestrado em Educação e Ensino de Professores Mestrado pelo Centro Pastoral Educacional e Assistência Dom Carlos (2002). Atualmente é professora Assistente D da Universidade Estadual do Centro-Oeste - UNICENTRO. Tem experiência na área de Artes, Educação e Educação Especial, atuando principalmente nos seguintes temas: educação, arte, ensino, arte-educação e inclusão.

\section{ELENICE MARIA FARIAS MORÃO DE MENEZES}

Licenciada em Pedagogia pelo Centro de Estudos Superiores de Parintins da Universidade do Estado do Amazonas. Especialização em Psicopedagogia pela FACIBRA/EDUCANORTE. É intérprete de Libras

\section{ELEUSY NATÁLIA MIGUEL}

Doutoranda em Economia Doméstica Universidade Federal de Viçosa (2018), Mestre em Economia Doméstica Universidade Federal de Viçosa (2016); Pós-Graduada Lato sensu de Cultura e Arte pela Universidade Federal de Ouro Preto (2016); Graduada em Arquitetura e Urbanismo pela Universidade Federal de Viçosa (2007) e Graduada em Economia Doméstica pela Universidade Federal de Viçosa (1997). Professora do curso de Arquitetura e Urbanismo da FACISA Viçosa/MG (UNIVIÇOSA) desde 2018.

\section{ELIANE MARINA PALHARES GUIMARÃES}

Graduação em Enfermagem e Obstetrícia pela PUCMINAS, doutorado em EERP/USP (2004) e mestrado em Ciências da Informação pela UFMG (1995). Professora associada II da Escola de Enfermagem da Universidade Federal de Minas Gerais/UFMG. Vice-Diretora Gestão 2010/2014 e Diretora Gestão 2014-2018 da Escola de Enfermagem da UFMG. Tem experiência na área de Enfermagem, com ênfase em Administração de Serviços de Enfermagem em Unidades de Saúde, atuando principalmente nos seguintes temas: gerência em saúde e na enfermagem, sistema de informação em saúde e na enfermagem, tecnologias educacionais, trabalho em rede e educação permanente mediatizada pela Internet.

\section{ELIENE NERY SANTANA ENES}

Mestre pelo Programa de Mestrado em Gestão Integrada do Território da Universidade Vale do Rio Doce (MG). Graduação em Psicologia pela Faculdade Dom Bosco de Filosofia, Ciências e Letras (1982), graduação em Pedagogia pela Faculdade de Filosofia Ciências e Letras de Governador Valadares (1976). Atualmente é professora dos cursos de Pedagogia e Psicologia na Universidade Vale do Rio Doce, atua também em Clínica de Psicologia/Psicanálise. Desenvolve trabalhos de ensino, pesquisa e extensão com as temáticas: Psicanálise e Educação, Diversidade e Inclusão, Território.

\section{ELTON ANDRÉ SILVA DE CASTRO}

Doutor em Psicologia (2017) pela Universidade Federal de Pernambuco (UFPE), Mestre em Desenvolvimento e Meio Ambiente (2004) e Graduado em Psicologia (2000) pela Universidade Federal de Alagoas (UFAL). É professor do Instituto Federal de Educação Ciência e Tecnologia de Pernambuco (IFPE) - Campus Afogados da Ingazeira e Líder do DesA (Grupo de Pesquisa "Processos de Desenvolvimento Humano e Aprendizagem: ambiente, cultura e subjetividade"). Tem interesse por práticas, pesquisas e reflexões sobre ciência, epistemologia, ética e bioética; produção de subjetividades contemporâneas; constituição do sujeito em diferentes contextos e a mediação da afetividade e, processos de significação e desenvolvimento humano. 


\section{ERI CRISTINA DOS ANJOS CAMPOS}

Ensino Médio (Magistério - Centro Educacional Vidal Ramos Júnior, concluído no ano de 1996). Em 2002 conclui-se graduação em Pedagogia Habilitação em Educação Infantil e Séries Iniciais, pela Universidade do Planalto Catarinense - UNIPLAC. Possui especialização em Psicopedagogia clínica e institucional e em Atendimento Educacional Especializado. Mestre em Educação pela Universidade do Planalto Catarinense - UNIPLAC. Atualmente trabalha na equipe da Educação Especial da Secretaria Municipal de Educação de Lages. Tem experiência na área de Educação, com ênfase em Ensino-Aprendizagem.

\section{ERIKA PATRÍCIA MARTINS FERREIRA}

Pedagoga e Especialista em Gestão Educacional, Educação Especial e no Ensino, Tradução e Interpretação da Língua Brasileira de Sinais; professora de Língua Brasileira de Sinais, no Instituto Federal de Educação, Ciência e Tecnologia do Maranhão - IFMA, Campus Viana.

\section{ERLANE CRISTHYNNE FELIPE DOS SANTOS}

Professora dos anos iniciais pela SEEC/RN. Mestre em Educação - UFRN/PPGED (2018), graduada em Pedagogia - UFRN (2015). Tem experiência na área de Educação, com ênfase em Educação Especial e Educação Inclusiva. Tem interesse acadêmico pela temática relacionadas à formação docente e aos processos de aprendizagem de estudantes com deficiência visual.

\section{FERNANDA COSTA SILVA}

Mestranda do Programa de Pós-Graduação em Administração do CEFET-MG. Possui Graduação em Secretariado Executivo pela Newton Paiva. Especialista em Administração Pública pela PUCMinas. Atualmente é Secretária Geral da Escola de Enfermagem da UFMG. Interesses de pesquisa ligados às áreas: Estudos Organizacionais e Estratégia, ênfase em análise institucional; Lei de Cotas; Pessoa com deficiência.

\section{FRANCINILDA RUFINO DE SOUZA}

Graduada em História pela Universidade Estadual da Paraíba - UEPB (2012). Mestra em Desenvolvimento Regional pelo Programa de Pós Graduação em Desenvolvimento Regional da UEPB/UFCG. Atuei como Professora Educadora no PROEXT MEC/SESu - UEPB (2013-2014). Fui pesquisadora do PROPESQ fazendo um levantamento sobre a implantação da Lei 10.639/03 na escola da comunidade quilombola Caiana dos Crioulos; e do PIBIC fazendo estudos sobre práticas de cura por meio de relatos orais de mulheres idosas na comunidade quilombola Caiana dos Crioulos. Tenho desenvolvido pesquisas, principalmente, nos seguintes temas: Educação, Formação Docente, História e Cultura Afro-brasileira e indígena, Memória Oral, Cultura regional nordestina e Políticas Públicas de Cultura.

\section{GISELI MONTEIRO GAGLIOTTO}

Pós-Doutorado em Psicologia (2015) pelo Observatório da Sexualidade da UNIDEP, no Departamento de Ciências Sociais e do Comportamento, do Instituto Universitário da MaiaPortugal. É Doutora em Educação (2009) pela Universidade Estadual de Campinas - UNICAMP/SP (PPG conceito 5 CAPES). Concluiu o Mestrado em Psicologia na UFSC - Universidade Federal de Santa Catarina - Florianópolis - SC no ano de 2000. Graduou-se em Psicologia na UFSC Universidade Federal de Santa Catarina - Florianópolis - SC no ano de 1997 e em Pedagogia na UDESC - Universidade do Estado de Santa Catarina em 1994. É Professora Associada A do Colegiado de Pedagogia e do Programa de Pós-Graduação Mestrado em Educação da Universidade Estadual do Oeste do Paraná - UNIOESTE, Campus de Francisco Beltrão. É líder do Laboratório e Grupo de Estudos, Pesquisas e Extensão: Educação e Sexualidade; - LABGEDUS, cadastrado no Diretório dos Grupos de Pesquisas do CNPq, coordenando a linha de pesquisa intitulada Estudos e Pesquisas Psicanalíticas e Educacionais sobre Infância, Sexualidade e Educação Sexual e sua importância para a formação docente\&quot;. Autora do livro: Educação Sexual na Escola e a 
Pedagogia da Infância: matrizes institucionais, disposições culturais, potencialidades e perspectivas emancipatórias. Paco Editorial, Jundiaí: 2014. Autora do livro: Contos de Fada e Desenvolvimento Psicossexual: o que pensam e dizem as crianças, o que fazem as professoras. Paco Editorial, Jundiaí: 2018

\section{GLAUCE VIRGINIA MOTTA REGIS}

Possui graduação em Biblioteconomia pela Universidade Federal do Estado do Rio de Janeiro (2007), graduanda Pedagogia pela Universidade Estadual do Norte- Fluminense Darcy Ribeiro (2017 até o momento), Pós graduanda em Educação Especial e Inclusiva e Neuropsicopedagogia Institucional e Inclusiva. Atualmente é bibliotecária do Instituto Superiores de Ensino do Censa. Tem experiência na área de Educação, com ênfase em bibliotecas: escolar, universitária.

\section{GLÁUCIA PEREIRA LIMA}

Especialista em Educação Especial pela UEL, Graduada em Ciências Sociais pela UEL. Professora do SAREH SME Londrina/PR.

\section{GLAYDSON DE OLIVEIRA SOARES}

Graduado em Nutrição pela Faculdade Católica Salesiana do Espírito Santo (2011) e Licenciando em Educação Profissional pelo Instituto Federal de Brasília (IFB), Mestrando em Educação Física pela Universidade Católica de Brasília (UCB), Especialista em Nutrição Clínica pelo Programa de Residência da Secretaria de Estado de Saúde do Distrito Federal/ ESCS (2016). Atua como nutricionista clínico em área hospitalar. Possui experiência como docente pela Secretaria de Estado de Educação do Distrito Federal. É integrante do Grupo de Estudo em Fisiologia do Exercício e Saúde (GEFES) da Universidade Católica de Brasília (UCB). Atualmente desenvolve pesquisa científica de suplementação nutricional em indivíduos com doença renal crônica em tratamento hemodialítico.

\section{HELOISA VALERIA MANGIA TORRES}

Professora do Colégio Pedro II desde 2010. Doutora em Literatura Comparada e Mestre em Literatura Brasileira pela Universidade do Estado do Rio de Janeiro (UERJ). No presente artigo, a paixão pela literatura se aliou ao prazer de ensinar e à busca de romper o paradoxo entre a enorme potencialidade de estudantes portadores de deficiência visual e as inúmeras dificuldades que enfrentam no dia a dia.

\section{JANAINA DA CRUZ MARTINS LIZZE}

Graduada em Pedagogia pela Universidade Estadual de Maringá. Especialização em Coordenação Pedagógica pela UFPR. Professora dos anos iniciais do ensino fundamental e pedagoga dos anos finais do ensino fundamental da rede pública.

\section{JAQUELINE TUBIN FIEIRA}

Graduada em Psicologia pela Universidade Bandeirantes (2009). Mestre em Educação pelo Programa de Pós-graduação da Universidade Estadual do Oeste do Paraná (2017). Possui especialização MBA em Recursos Humanos pela Univel (2011). Pesquisadora do grupo de estudos "Educação e Sociedade" (GEDUS) da UNIOESTE - Francisco Beltrão/PR. Tem experiência na área de Educação, atuado como orientadora educacional da educação infantil do Colégio Unisep e na Associação de Proteção aos Autistas de Dois Vizinhos (APADV). Atuou na área de Recursos Humanos, como psicóloga organizacional, com foco na educação corporativa na empresa Latreille. Atualmente é professora de Psicologia na União de Ensino do Sudoeste do Paraná (UNISEP) campus Francisco Beltrão e Dois Vizinhos, desde 2010 e na Pós-graduação desde 2017. Atua como Psicóloga clínica, com a abordagem psicanalítica, no Centro Clínico Oasis. Realiza palestras na área da educação, educação sexual e na área de gestão de pessoas. 


\section{JEFFERSON DIEGO DE JESUS}

Professor Surdo, Mestre na linha pesquisa políticas educacionais - UFPR. Especialista em Educação Bilíngue para surdos, graduado em Letras Libras. Professor na Universidade Federal do Paraná.

\section{JOAQUIM BRAGA}

Especialista em Educação Profissional Integrada à Educação Básica na Modalidade para Jovens e Adultos pela UTFPR. Licenciado em Letras pela UEL. Professor do SAREH-SEED/PR.

\section{JODELMA CASTELO BRANCO MENDES}

Graduada em Pedagogia pela Universidade Federal do Maranhão, Especialista em Gestão, Supervisão e Orientação Educacional pela Faculdade Santa Fé, Pedagoga no Instituto Federal de Educação, Ciência e Tecnologia do Maranhão. Exerce o cargo de Diretora de Desenvolvimento Educacional no IFMA Campus Viana desde 2016.

\section{JOMAR RICARDO DA SILVA}

Possui graduação em História (1991), Especialista em Brasil República (1995), Mestrado em Sociologia (1998), pela Universidade Federal da Paraíba (atualmente Universidade Federal de Campina Grande, UFCG, Campus I) e doutorado em Educação pela Universidade Federal do Rio Grande do Norte (2007). É professor Associado da Universidade Estadual da Paraíba. Tem experiência na área de Sociologia, atuando nos temas cidadania e participação social.

\section{JORDANA RABELO SOARES}

Possui graduação em Biblioteconomia pela UNIFOR (2003). Especialização em Biblioteconomia e Documentação (2010)Atualmente é bibliotecária na Escola de Enfermagem da Universidade Federal de Minas Gerais. Trabalha com normalização e correção dos artigos publicados na REME Revista Mineira de Enfermagem. Realiza a edição e indexação dos artigos da REME nas bases de dados BDENF e LILACS. Trabalha no controle bibliográfico da Biblioteca Virtual de Saúde Enfermagem (BVS) e coordenação dos bibliotecários da REDE Enfermagem Lilacs/ Bireme AL\&C. Tem experiência na área de Ciência da Informação, com ênfase em Biblioteconomia.

\section{JULIANNA MENDES DE MATOS SOUZA}

Possui graduação em Pedagogia pela Universidade de Brasília (2009). Especialização em Orientação Educacional pela Facibra (2013). Especialização em Docência na Educação Infantil pela Universidade de Brasília (2015). Mestranda em Educação Física pela Universidade Católica de Brasília (2019). Atualmente é professora - Secretaria de Educação do Distrito Federal. Tem experiência na área de Educação, com ênfase em Educação Infantil, Educação Especial e Educação Precoce.

\section{KELLY JESSIE QUEIROZ PENAFIEL}

Doutoranda em Educação pela Universidade Federal de Minas Gerais (UFMG). Integrante do Grupo de Estudos e Pesquisas em Psicologia Histórico-Cultural na Sala de Aula (GEPSA) e do Grupo de Estudos em Cultura, Educação e Infância (EnlaCEI), ambos da FaE/UFMG. Graduada em Pedagogia (2009) e mestre em Psicologia (2012) pela Universidade Federal de Rondônia (UNIR), com estágio sanduíche na Universidade de São Paulo (USP). Especialista em Educação Infantil pela Universidade Católica Dom Bosco (UCDB) e em Alfabetização e Letramento pela Universidade Municipal de São Caetano do Sul (USCS). Integrante do Grupo de Estudos Pedagógicos (GEP) na linha de pesquisa Psicologia e Aprendizagem Escolar. Professora da Universidade Federal de Rondônia (UNIR), campi Vilhena, na área de ensino-aprendizagem. 


\section{LETÍCIA JAFAR DA FONSECA}

Mestranda do Programa de Pós-Graduação em Administração do CEFET-MG. Possui Graduação em Ciências Biológicas pela PUCMINAS. MBA em Gestão de Projetos pela UNA. Atualmente é servidora TAE da UFMG. Interesses de pesquisa ligados às áreas: Estudos Organizacionais e Estratégia, ênfase em análise institucional; Lei de Cotas; Pessoa com deficiência.

\section{LUIZ ANDRÉ BRITO COELHO}

Professor surdo- UTFPR, especialista em educação bilíngue para surdos, pesquisador na área da surdez, graduado em matemática e Letras Libras; Mestrando pela UTFPR-PG (Mestrado Profissionalizante).

\section{LURDES CARON}

Possui graduação em Pedagogia pela Faculdade de Filosofia Ciências e Letras do Vale do Itajaí (1975), mestrado em Teologia Prática - Educação Cristã pela Escola Superior de Teologia Instituto Ecumênico de Pós Graduação (1995) e Doutorado em Educação: Currículo - pela Pontifícia Universidade Católica de São Paulo (2007), Pós-Doutoral em Educação e Religião pela PUCPR em 2016. É associada do Fórum Nacional Permanente do Ensino Religioso - FONAPER. Fez parte do Grupo de Assessoria e Pesquisa, do Setor de Ensino Religioso, da Conferência Nacional dos Bispos do Brasil - CNBB - (GRAPER/CNBB). Associada da Associação Catarinense de Professores de Santa Catarina. Docente Pesquisadora do Mestrado Acadêmico em Educação - da Universidade do Planalto Catarinense, é professora titular e, professora na graduação da Universidade do Planalto Catarinense. Faz parte da Comissão Institucional de Acessibilidade - CIA da UNIPLAC. Tem experiência na área de educação e gestão, com ênfase em Ciências Humanas, atuando principalmente nos seguintes temas: formação de professores, ensino religioso, metodologia e história do ensino religioso, educação especial, currículo, legislação, gestão, pesquisa e prática pedagógica e metodologia de pesquisa. Coordenadora do Grupo de Pesquisa: FORMAÇÃO DE PROFESSORES: POLÍTICAS CURRICULARES E PRÁTICAS INCLUSIVAS PARA A CULTURA DA PAZ NA EDUCAÇÃO - FORPAZ. Autora de vários livros sobre Formação de Professores de Ensino Religioso e Educação Especial, Avaliação: Políticas e Práticas.

\section{MARCELO ELISIO VASICKI}

Professor Surdo- UEPG, foi presidente da Associação de Surdos de Curitiba, graduado em Letras Libras pela UFSC, Atualmente cursa o Mestrado Profissionalizante na UTFPR/PG

\section{MARCIA RAIKA E SILVA LIMA}

Doutora em Educação/UFPI (2016), Mestrado em Educação/ UFPI (2010). Especialização em Educação Inclusiva e Especial com ênfase em Neurociência (cursando). Especialista em Supervisão Escolar/UFPI, em Gestão Educacional/ UNICESP e em Língua Brasileira de Sinais, possui Graduação em Licenciatura Plena em Pedagogia/UFPI. Professora Adjunta 1 da UEMA/ Centro de Estudos Superiores de Caxias. Professora do Mestrado Profissional em Educação Inclusiva UNESP/UEMA. Foi Gerente de Educação Especial do Estado do Piauí (2011-2014), trabalhou no Núcleo de Atividades de Altas Habilidades/Superdotação (2007-2008), professora substituta da UEMA -Timon-MA (2011-2012) e como professora convidada da Faculdade Santo Agostinho. Tem experiência na área de Educação, trabalhando com as diferentes disciplinas da área da Pedagogia, com ênfase em Educação Especial e Inclusiva e LIBRAS. Participou do Núcleo de Estudos e Pesquisas em Educação na Psicologia Sócio-Histórica (UFPI). Participa do Grupo de Pesquisas Interdisciplinares: educação, saúde e sociedade e do Grupo de Estudos e Pesquisas Interdisciplinar do Centro de Estudos Superiores de Caxias (GEPICESC). 


\section{MÁRCIA VERÔNICA COSTA MIRANDA}

Possui graduação em Técnico Em Nível Superior Em Processamento de Dado pela Universidade Federal da Paraíba (1985), hoje intitulado Sistemas de Informações, mestrado em Ciência da Computação pela Universidade Federal da Paraíba (1996) e doutorado em Doutorado em Engenharia Elétrica pela Universidade Federal de Campina Grande (2003). Atualmente, é professora associada da Universidade Federal da Paraíba. Tem experiência na área de Engenharia Elétrica, com ênfase em Engenharia da Computação, atuando principalmente nos seguintes temas: Tecnologia da Informação e Comunicação, Educação, Inclusão social, Informática e inclusão digital. Desenvolve e executa diversos projetos na área de extensão universitária, notadamente Extensão rural, com temática na Educação e Inclusão social e digital.

\section{MARIA APARECIDA PEREIRA}

Graduada em Serviço Social pela Universidade Federal da Paraíba - UFPB, com experiência na área da Educação, onde atuou em temas como Programa Bolsa Família e suas condicionalidades, Serviço Social, Inclusão Escolar, Bullying, Violência na Escola. Em 2015 foi colaboradora na primeira fase do Projeto de Extensão (PROBEX) intitulado O PROGRAMA BOLSA FAMÍLIA (PBF) E SUAS CONDICIONALIDADES NA EDUCAÇÃO: o acompanhamento e monitoramento dos(as) alunos(as) em descumprimento na Escola Municipal Nazinha Barbosa da Franca. Em 2016 foi bolsista na $2^{\text {a }}$ fase do supracitado Projeto de Extensão. Pesquisadora do Projeto de Pesquisa intitulado "Prisão e Educação um hiato histórico: da cela à sala de aula, um caminho para a educação ao longo da vida?". Autora do livro Violência Escolar - Aspectos que contribuem para essa prática, publicado em 2017 pela Editora Novas Edições Acadêmicas, Düsseldorf, Alemanha.

\section{MARIA DE FÁTIMA LEITE GOMES}

Possui graduação em Serviço Social pela Universidade Federal da Paraíba (1987), Especialização em Metodologia das Ciências pela Universidade Estadual da Paraíba (1991), Mestrado em Serviço Social pela Universidade Federal da Paraíba (1997) e Doutorado em Serviço Social pela Universidade Federal de Pernambuco (2011), na Área de Concentração em Serviço Social, Movimentos Sociais e Direitos Sociais. É professora da Universidade Federal da Paraíba atuando na Graduação e no Programa de Pós-Graduação em Serviço Social da Universidade Federal da Paraíba (UFPB).. Tem experiência na área de Serviço Social, com ênfase em Política de Assistência Social, Fundamentos do Serviço Social e Movimentos Sociais. Foi Chefe do Departamento de Serviço Social da UFPB, no período 2001-2006, e Vice-Presidente Regional da Associação Brasileira de Ensino e Pesquisa em Serviço Social (ABEPSS), no período 2003-2004. Ministrou disciplinas na PósGraduação (lacto-sensu) em Serviço Social da UFPB, além de participação em Cursos de formação de curta duração. Foi colaboradora do Conselho Municipal de Assistência Social (CMAS), de João Pessoa-PB., entre 2013-2014. Orienta e coordena projeto de extensão e projetos de iniciação científica (PIBIC e PIVIC), vinculados à UFPB e ao CNPQ, respectivamente. É a segunda líder do Grupo de Estudos e Pesquisas em Educação Popular, Serviço Social e Movimentos Sociais (GEPEDUPSS), vinculado ao Departamento de Serviço Social e ao Programa de Pós-Graduação em Educação (PPGE), da UFPB. Foi Membro da Associação Latinoamericana de Sociologia, no período correspondente a 2013-2015. É vice-chefe do Departamento de Serviço Social da UFPB, desde 2016.

\section{MARIA DE LOURDES ZACARIAS DA SILVA}

Graduada em Serviço Social pela Universidade Federal da Paraíba. Possui experiência nas Políticas de Saúde Mental, Política de Assistência Social e Política de Educação, atuando principalmente nas seguintes temáticas: Usuários Crônicos, Desinstitucionalização, Serviços Substitutivos, Violências e Violações de Direitos, Crianças, Adolescentes e Famílias, Vulnerabilidade, Proteção Social, Programa Bolsa Família e suas Condicionalidades. Participou como pesquisadora da pesquisa intitulada: Violação de direitos e vulnerabilidade social de crianças e adolescentes e famílias no Estado da Paraíba e as políticas de enfrentamento. Vinculada ao grupo de estudos e pesquisa sobre crianças, adolescentes e famílias (GEPAC), ao departamento de serviço social (DSS) e ao programa de pós-graduação e serviço social (PPGSS) da universidade federal da Paraíba (UFPB). 


\section{MARIA DO SOCORRO DE SOUSA}

Licenciada em Pedagogia e Especialista em Gestão de Políticas Públicas em Gênero e Raça (UFPI). Bacharel em Biblioteconomia (UESPI). Bibliotecária no Instituto Federal de Educação, Ciência e Tecnologia do Maranhão - IFMA, Campus Viana

\section{MARIA GORETTI RODRIGUES DE SOUSA OLIVEIRA}

Graduada em Serviço Social pela Universidade Federal da Paraíba (UFPB), experiência na Educação. Com ênfase nos seguintes temas: Educação, Programa Bolsa Família e suas condicionalidades, Serviço Social, Inclusão Escolar, Bullying, Violência na Escola. 2015 Colaboradora na primeira fase do Projeto de Extensão intitulado O PROGRAMA BOLSA FAMÍLIA (PBF) E SUAS CONDICIONALIDADES NA EDUCAC̄̃̃O: o acompanhamento e monitoramento dos(as) alunos(as) em descumprimento na Escola Municipal Nazinha Barbosa da Franca .2016, Bolsista na segunda fase do referido Projeto. 2016 Bolsista na segunda fase do Projeto supracitado; Desenvolveu atividade de Monitora Voluntária no PROJETO DE MONITORIA da disciplina Ética em Serviço Social, orientada pela Profa ${ }^{2}{ }^{a}$ M ${ }^{a}$ de Fátima Leite Gomes. Pesquisadora do Projeto de Pesquisa intitulado "Prisão e Educação um hiato histórico: da cela à sala de aula, um caminho para a educação ao longo da vida?". 2017- Autora do livro Violência Escolar - Aspectos que contribuem para essa prática, Editora Novas Edições Acadêmicas, Düsseldorf, Alemanha 2018.Graduanda em Psicopedagogia pela Universidade Federal da Paraíba (UFPB)2019.

\section{MARIA ROSELENE SOARES MARQUES}

Sou estudante de Letras Português Literaturas da Universidade Federal do Rio de Janeiro (UFRJ). Estou no quarto período da graduação e, até o presente momento, atuei como palestrante em algumas mesas que versavam sobre a relação da pessoa com deficiência visual e a literatura; a mulher com deficiência na sociedade e participei da mesa "Inclusão ou inserção". Participei também do Congresso Nacional de Práticas Inclusivas (CONAPI), palestrando sobre o conteúdo do presente artigo. Sou uma estudante que, aprende diariamente a lidar com os diversos desafios impostos pela sociedade. Transformo-os em incentivo para provar, não para o mundo, mas para mim o quão sou capaz de vencer as minhas limitações. Utilizar a literatura como meio de compartilhar um pouco dos desafios e aprendizados que me fizeram crescer bastante como pessoa é algo imensamente gratificante.

\section{MARIANA SANTANA FACINA}

Graduada em Pedagogia pela Universidade Estadual de Maringá. Especialização em Psicopedagogia, Neuropsicopedagogia e Educação Especial e Inclusiva pela Faculdade de Ensino Superior Dom Bosco. Especialização em Gestão Escolar Integrada e Práticas Pedagógicas pela Faculdade Eficaz. Professora mediadora na Unicesumar - EAD.

\section{MARINÊS DIAS GONÇALVES}

Possui graduação em Pedagogia Educação Especial (2001), Especialização em Educação Especial (2007) e Mestrado em Educação (2017). Proficiente no uso da Língua Brasileira de Sinais (Libras). Atualmente é docente no Instituto Federal Catarinense - Campus Rio do Sul. Tem experiência na área de Educação Especial, atuando principalmente nos seguintes temas: libras e educação inclusiva.

\section{MARIO CÉZAR ALVES FERREIRA}

Mestre em Educação pela UTFPR. Especialista em Educação Especial pela UNOPAR e em Educação de Jovens e Adultos pela UEL. Licenciado em História pela UEL. Professor do SAREH-SEED/PR. 


\section{MARTHA CAROLINE DUARTE DE BRITO FREITAS}

Mestre em Cognição e Linguagem (UENF). Professora de Língua Portuguesa, atuando com turmas do $2^{\mathrm{o}}$ ciclo do Ensino Fundamental. Tutora presencial no curso de Licenciatura em Letras (UNOPAR). Experiência em Cursos Pré-Vestibular e Pré-Técnico. Licenciada em Letras pela Faculdade de Filosofia de Campos (2009). Possui Pós-graduação lato sensu em Língua Portuguesa e Literatura Brasileira pela FACEL/PR. Seus interesses de pesquisa concentram-se nos seguintes temas: crença de autoeficácia, linguagem, escrita, gramática, ENEM, literatura brasileira, autorregulação da aprendizagem (psicologia da aprendizagem) e metodologias de ensino.

\section{MAYCON CESAR PEREIRA WERNZ}

Atualmente, professor de Língua Portuguesa/ Inglesa do IFMA campus Viana. Tem experiência na área de Lingüística, com ênfase em Linguística Textual, atuando principalmente nos seguintes temas: gêneros e discurso, retextualização e leitura.

\section{NÁDIA MAROTA MINÓ}

Doutoranda (fase conclusiva) pelo Programa de Pós-Graduação em Economia Doméstica/PPGED (Famílias Políticas Públicas e Desenvolvimento Humano e Social) pela Universidade Federal de Viçosa (UFV). Bolsista da Fundação CAPES. Mestre pelo PPGED/UFV (2016). Licenciada em Pedagogia UFV (2013). Colaboradora voluntária do Projeto de Extensão "Esta Ruga tem História?" no Programa Municipal da Terceira Idade - PMTI/Parceria entre a UFV e Prefeitura Municipal de Viçosa. Período: 2013 à 2016.

\section{NISIA CAMARGO CAETANO DI NIZO FANTINELLI}

Mestranda pela Universidade Estadual do Norte do Paraná (UENP) Campus Cornélio Procópio Programa de Pós-graduação em Ensino (PPGEN) Mestrado Profissional em Ensino. Pós-graduada em Psicopedagogia Institucional, Clínica e educação Especial - Faculdade Venda Nova do Imigrante (FAVENI). Pós-graduada em Docência no Ensino Superior - Faculdade São Braz. Graduada em Pedagogia - Faculdade educacional da Lapa (FAEL).

\section{PASCOAL ERON SANTOS DE SOUZA}

Mestre em Educação e Diversidade pelo Programa de Pós-Graduação em Educação e Diversidade PPED/MPED pela Universidade do Estado da Bahia - UNEB (2017). Tem especialização em Educação, Cultura e Contextualidade pela UNEB (2010); especialização em Psicopedagogia pela Faculdade Internacional de Curitiba- FACINTER/IBPEX (2002) e em Ensino da Língua Inglesa pela Universidade de Pernambuco - UPE (2006). Licenciatura em Pedagogia pela UNEB (2001) e Licenciatura em Língua Inglesa e suas Literaturas pela UPE (2007). É professor do Departamento de Educação do Campus VII/UNEB. Desenvolve estudos na área de Educação, com ênfase em Educação Inclusiva, Didática, Educação de Surdos, Pesquisa e Prática Pedagógica, e Ensino da Língua Inglesa.

\section{RENATA GRECO DE OLIVEIRA}

Graduada em Pedagogia pela Universidade Vale do Rio Doce. Especialista em Docência do Ensino Superior. Mestre em Educação pela Universidade Federal do Rio Grande Sul. Professora no Ensino Superior desde 2002: Faculdade de Mantena (2002-2005), Universidade Presidente Antônio Carlos (2005-2009), Universidade Vale do Rio Doce - UNIVALE (2011-atual). Atuou como Coordenadora Institucional do PIBID-UNIVALE, e do curso de Pedagogia da UNIVALE e como representante do Ensino Superior no Conselho Municipal da Educação (CME) de Governador Valadares. Tem experiência na área de Educação, com ênfase em Pesquisa em Educação, nos seguintes temas: formação política, identidade, aprendizagem, universidade e educação à distância. Atualmente atua com extensão. 


\section{RENNER DOUGLAS GONÇALVES DUTRA}

Mestre em Educação e Ensino de Ciências na Amazônia pela Universidade do Estado do Amazonas (2014), Especialização em Educação de Jovens e Adultos pela Universidade Federal do Amazonas (1996), Bacharelado em Teologia pela Pontifícia Universidade Católica do Rio de Janeiro (1987), Licenciatura em Filosofia pela Universidade Estadual do Ceará (1996), Curso de Filosofia pela Faculdade Eclesiástica de Filosofia João Paulo II - Arquidiocese do Rio de Janeiro (1983). Professor concursado da Universidade do Estado do Amazonas. Tem experiência nas áreas de Filosofia e Sociologia com ênfase em Filosofia da Educação, Religião, Cultura e da Sociologia da Infância

\section{RICARDO JOSÉ ROCHA AMORIM}

Possui Pós Doutorado, Doutorado e Graduação em Ciência da Computação. Atualmente, exerce atividades docentes na graduação e em programas de pós-graduação Stricto Sensu. Coordena projeto de pesquisa no INES - Instituto Nacional de Ciência e Tecnologia para Engenharia de Software, atuando na área de Ciência da Computação com ênfase em Inteligência Artificial, Representação de Conhecimento e Engenharia de Software. Também, atua na área de Informática na Educação, com ênfase em Ontologia Educacional, Padrões de Metadados Educacionais, Objetos de Aprendizagem, Learning Design e Learning Analytics.

\section{RONALDO QUIRINO DA SILVA}

Mestre em Distúrbios da Comunicação e Linguagem, especialista em educação bilíngue para surdos, graduado em pedagogia, pesquisador da área da surdez. Professor no ensino superior e diretor da empresa Librandus "Excelência na Língua de Sinais".

\section{ROSANE DA SILVA NUNES}

Professora de Jornalismo da Universidade Federal do Cariri (UFCA), doutoranda em Educação (UFRN), mestra em Desenvolvimento e Meio Ambiente (UFC), especialista em Gestão da Comunicação (UFC), graduada em Comunicação Social - Jornalismo (UFC). Integrante do Grupo de Pesquisa Estudos de Mídia - Análises e pesquisa em cultura, processos e produtos midiáticos (UFRN).

\section{SÂMMYA FARIA ADONA LEITE}

Tem experiência na área de Educação, com ênfase em DIDÁTICA, PRÁTICAS DE ENSINO, ASPECTOS PEDAGÓGICOS, EDUCAÇÃO A DISTÂNCIA, COMUNICAÇÃO, PSICOMOTRICIDADE, ARTE E EDUCAÇÃO.

\section{SEPHORA SANTANA SOUZA}

Pedagoga formada pela Universidade Federal do Maranhão, atua como professora de educação infantil pela prefeitura de Icatu, atuou como: professora formadora do ESCOLA DA TERRA, professora (Educ. Infantil) em São José de Ribamar, técnico de educação - supervisão pedagógica no SENAI, professora e ex-extensionista do PRONERA/UFMA, pesquisadora e membro do NEPHECC( Núcleo de Estudos e Pesquisas em História,Politica e Educação do Campo).Onde participou enquanto pesquisadora da Pesquisa intitulada "Terra e Educação: a história da Participação dos Movimentos Sociais do Campo e das Familias Assentadas e Áreas de Reforma Agraria no Estado do Maranhão). Hoje atua principalmente nos seguintes temas: formação de professores, gestão escolar, escolas multisseriadas, Educação do Campo, PSICOLOGIA DA EDUCAÇÃO, ESCOLA DA TERRA, PRONERA, Projeto Político Pedagógico e Saber Social." 


\section{SILVANA CAROLINA FURSTENAU DOS SANTOS}

Cursa Doutorado em Educação Física, pela Universidade Católica de Brasília - UCB, bolsista PROSUC/CAPES. Mestre em Educação Física - UCB. Especialista em Psicopedagogia; Pedagogia Empresarial; Gestão e Orientação Educacional; Docência do Ensino Superior, Profissional e Tecnológico. Licenciada em Educação Física e em Pedagogia. Atua como docente da Universidade Paulista - UNIP, nos cursos de Gestão de Recursos Humanos, Pedagogia e Fisioterapia. É docente no Centro Universitário ICESP, nos cursos de Educação Física e Fisioterapia. Docente no Instituto Brasileiro de Ensino e Cultura - DF, no curso de Educação Física. É membro do Comitê de Ética e Pesquisa do Centro Universitário ICESP.

\section{SILVANA ELISA DE MORAIS SCHUBERT}

Doutora e mestre em educação, especialista em educação especial, educação infantil e educação bilíngue para surdos. Professora do ensino superior FAEL, UTP/PR, e educação básica na prefeitura de Araucária, pesquisadora e escritora na área da surdez e literatura infantil, psicanalista pela Associação Brasileira de Psicanálise INSIGHT.

\section{SIMONE SOUZA SILVA}

Doutora em Educação pelo Programa de Pós-Graduação em Educação da Universidade Federal do Amazonas. Mestre em Educação e Ensino de Ciências pelo Programa de Pós-Graduação em Educação e Ensino de Ciências na Amazônia pela Universidade do Estado do Amazonas. Licenciada em Pedagogia pela Universidade Federal do Amazonas. É professora de Graduação e de PósGraduação no Centro de Estudos Superiores de Parintins da Universidade do Estado do Amazonas, ministrando as disciplinas de Metodologia do Estudo, Didática, Epistemologia da Pesquisa Educacional, Pesquisa e Prática Pedagógica I, Pesquisa e Prática Pedagógica II e Estágio. Tem experiência na área de Educação, com ênfase em educação científica, currículo, formação inicial de professores, trabalho docente e educação do campo.

\section{VALÉRIA LEITE DA SILVA}

Graduada em Pedagogia pela Universidade Federal de Rondônia (UNIR). Pós-graduada em Práticas na Docência Infantil pela FAEL.

\section{WILLIAMS ALVES XAVIER}

Graduando em Agronomia pela Universidade Federal da Paraíba - Campus II, atualmente é voluntário em projetos de extensão universitária do Departamento de Ciências Fundamentais e Sociais, na área de inclusão rural através da informática. Também é estagiário do Departamento de Fitotecnia do centro e foi monitor bolsista das disciplinas de Informática e Química Orgânica. É Técnico em Administração formado pela Escola Técnica Miguel Arraes de Alencar - PE, e durante o ensino médio realizou intercâmbio na Harbour View High School - Canadá.

\section{WYLKER SOUZA SARAIVA}

Mestrando em Educação Física UCB- Universidade Católica de Brasília-Graduado em Educação Física 2001/1 no Centro Universitário UNIRG. Especialização em Educação Física com ênfase em treinamento Esportivo (Iep-Marabá-PA). Atualmente professor substituto do Curso de Educação Física do Centro Universitário Unirg e em 2015/2 começa a exercer sobre regime estatuário no Município de Gurupi o cargo de Professor de Educação Física. Professor destaque da área da Educação Física pelo Prêmio Professores do Brasil do ano de 2017. 


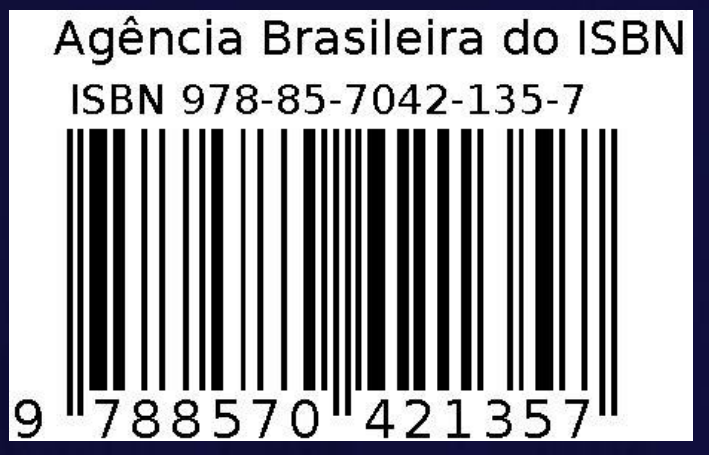

